\title{
Dual Nickel- and Photoredox-Catalyzed Reductive Cross-Coupling to Access Chiral Trifluoromethylated Alkanes
}

\author{
Pan Zhou, Xinxuan Li, Dong Wang, and Tao XU*
}

Shanghai Key Laboratory of Chemical Assessment and Sustainability, School of Chemical Science and Engineering, Tongji University, 1239 Siping Road, Shanghai, 200092, P. R. of China

\section{Supporting Information}

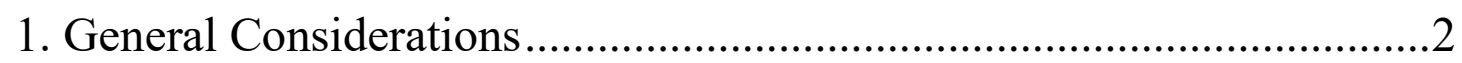

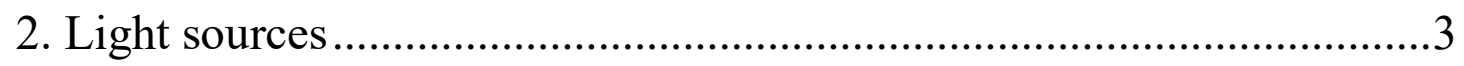

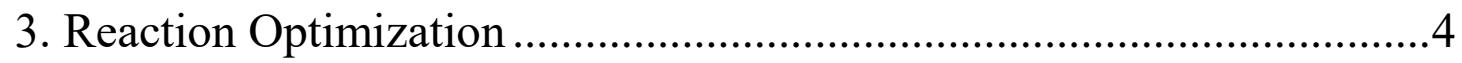

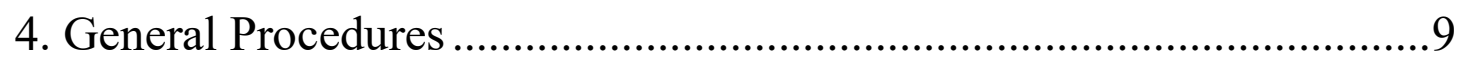

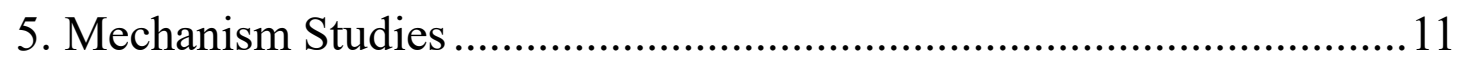

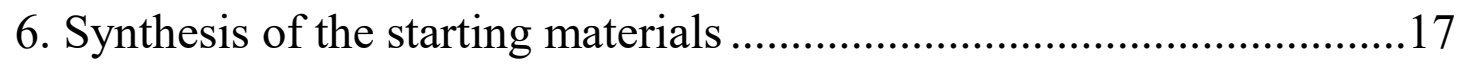

7. The characterization of the compounds ............................................23

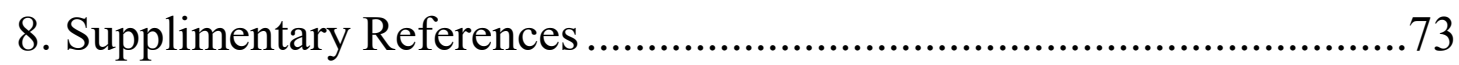

9. Spectra data for the compounds.................................................... 74 


\section{General Considerations}

${ }^{1} \mathrm{H}$ and ${ }^{13} \mathrm{C}$ spectra were recorded on a Bruker Avance 400, 600 spectrometers, and $\mathrm{CDCl}_{3}$ was purchased from $\mathrm{J} \& \mathrm{~K}$. Chemical shifts are given in ppm with the internal standards as TMS $\left(0 \mathrm{ppm}\right.$ for $\left.{ }^{1} \mathrm{H}\right)$ and $\mathrm{CDCl}_{3}\left(77.0 \mathrm{ppm}\right.$ for $\left.{ }^{13} \mathrm{C}\right)$. Flash column chromatography was performed on silica gel 60 (particle size 200-400 mesh ASTM, purchased from Yantai, China) and eluted with petroleum ether/ethyl acetate. GC spectra were recorded on Agilent Technologies 7890A spectrometer; GC-MS spectra were conducted on Shimadzu GC-MS-QP2010 SE W spectrometer; HPLC analysis was performed on Thermo Fisher Ultimate 3000 spectrometer; Optical rotation was measured using a Rudolph AUTOPOL VI polarimeter; High resolution mass spectra HRMS-ESI were obtained from a Bruker micrOTOF-II instrument. All reactions were performed under a $\mathrm{N}_{2}$ atmosphere using dried solvents which were dried and purified according to the procedure from 'Purification of Laboratory Chemicals book'. 


\section{Light sources}

Reactions were optimized with $30 \mathrm{~W}$ blue LED lamps（450-455nm） purchased from the Taobao web store.

https://item.taobao.com/item.htm?spm=a1z10.3-c.w4002-15754154531.36.2e3cd eabd55EgT\&id $=603545564757$

The Schlenk tube was kept 4-6 cm away from the lights, with cooling fan to keep the reaction temperature at $20-30{ }^{\circ} \mathrm{C}$. A fan was placed $6 \mathrm{~cm}$ above the LED lamps for cooling and a second fan was placed in front.

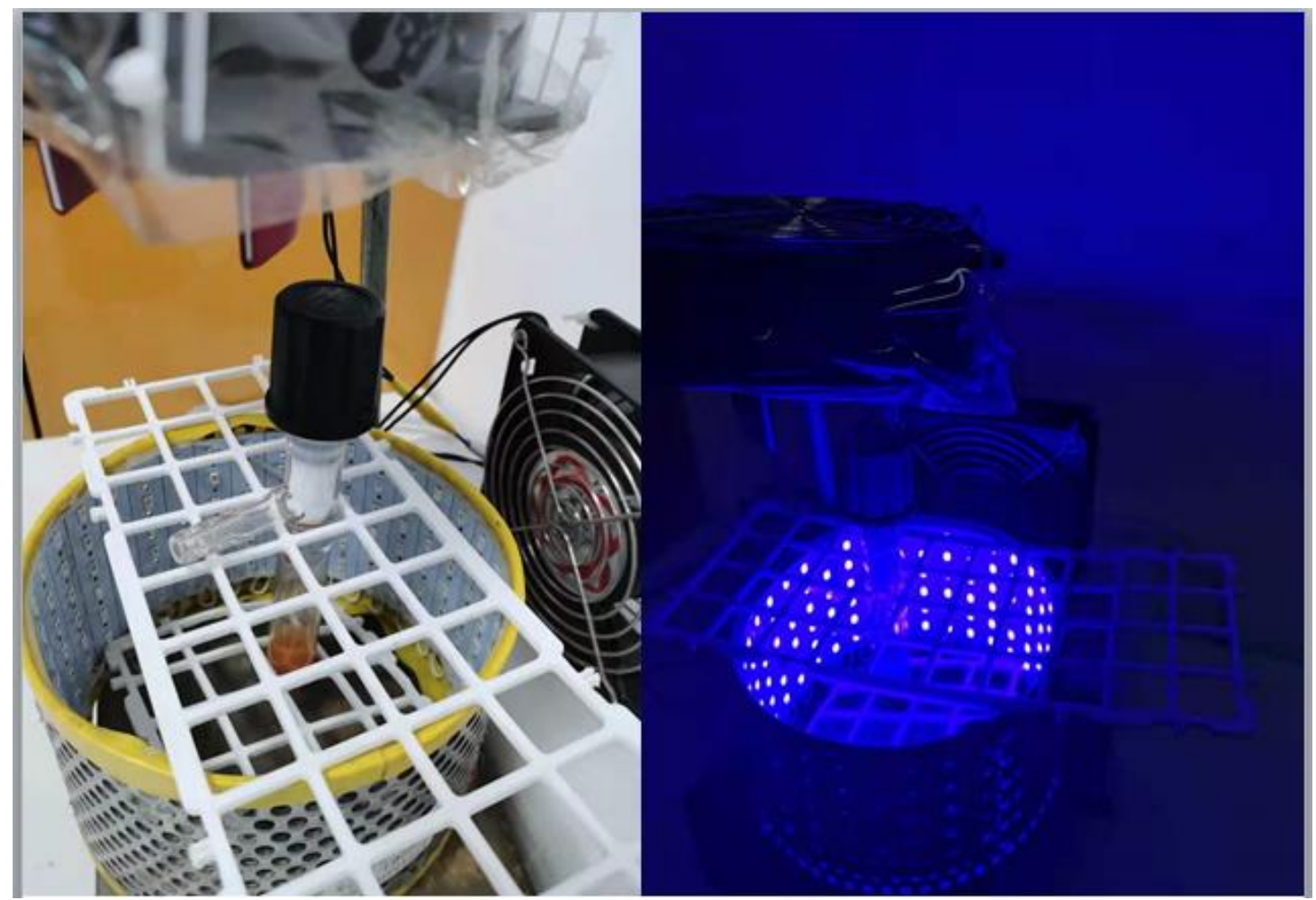

Figure S1. Photochemical Setup (taken in our laboratory) 


\section{Reaction Optimization}

General Procedure: An oven-dried 10-mL Schlenk tube containing a Teflon stir bar was charged with 4CzIPN (0.001 mmol, $1 \mathrm{~mol} \%)$, Ni-catalyst $(0.01 \mathrm{mmol}, 10$ mol\%), ligand (0.012 mmol, $12 \mathrm{~mol} \%)$, HEH (0.2 mmol, 2 equiv.), $\mathrm{Et}_{3} \mathrm{~N}(0.5 \mathrm{mmol}, 5$ equiv.). Then the tube was sealed with a septum and taken out of the $\mathrm{N}_{2}$-filled glovebox. The solvent $(2 \mathrm{~mL})$ was added via syringe under $\mathrm{N}_{2}$ atmosphere and the reaction mixture was stirred for $1 \mathrm{~h}$ at room temperature. Then $\mathbf{2 a}(0.1 \mathrm{mmol})$ and aryl halide $1 \mathrm{a}(0.15 \mathrm{mmol}, 1.5$ equiv.) were added via micro-syringes. Once added, the tube was sealed again, and the reaction mixture was stirred and irradiated under blue light $(\lambda=450-455 \mathrm{~nm})$ for 8-10 hours, while the temperature was controlled at approximately $20{ }^{\circ} \mathrm{C}-30{ }^{\circ} \mathrm{C}$ by cooling with fans and air-conditioner. Upon completed, the reaction mixture was quenched with water and diluted with EtOAc before the internal standard ( $n$-dodecane) were added. The yield was determined by GC analysis, and the er value was obtained by HPLC analysis.

Supplementary Table 1. Screening results on ligand

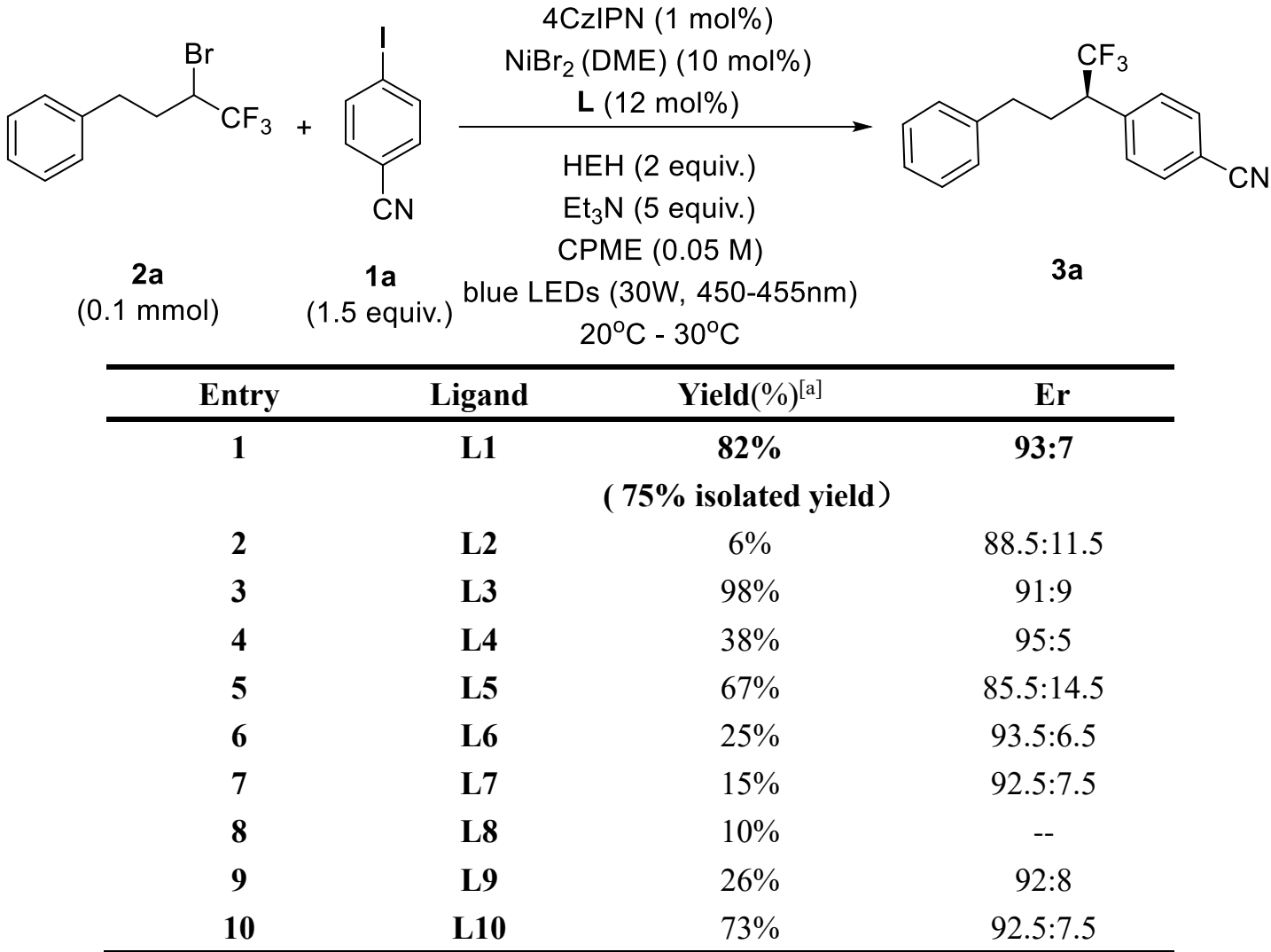

[a] GC yield using $n$-dodecane as the internal standard. Reaction run at a $0.10 \mathrm{mmol}$ scale. 


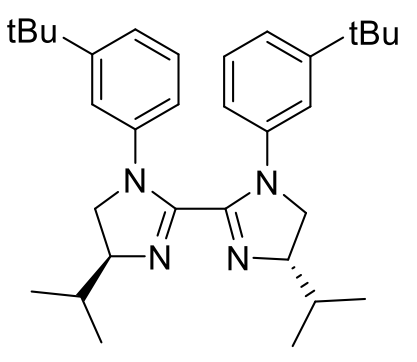

L1<smiles>CCCC(C(C)C)[C@@H](CC)CC(C)C</smiles>

L4<smiles>Cc1cccc(N2C[C@H](C(C)C)N=C2C2=N[C@H](C(C)C)CN2c2cccc(C)c2)c1</smiles>

L9

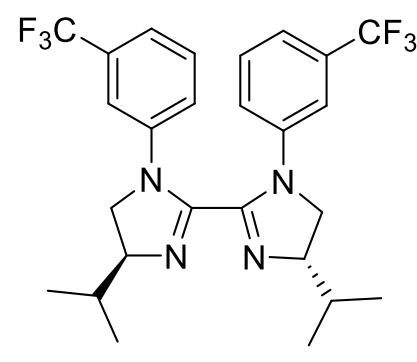

L2

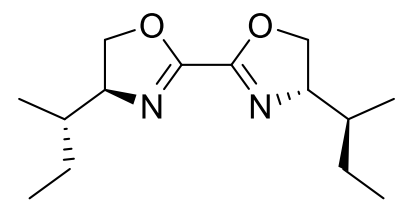

L5

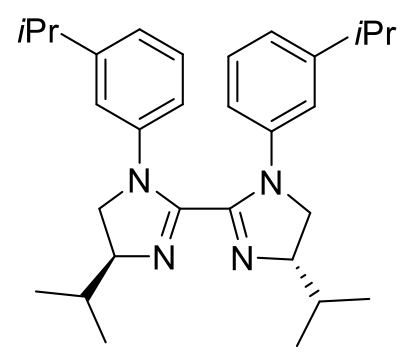

L10<smiles>CC[C@H](C)[C@H]1CN(c2cccc(C(C)C)c2)C(C2=N[C@H]([C@@H](C)CC)CN2c2cccc(C(C)(C)C)c2)=N1</smiles>

L3<smiles>[R]C1COC(C2=NC([R])CO2)=N1</smiles>

L6: $\mathrm{R}^{1}={ }^{i} \mathrm{Pr}$

L7: $\mathrm{R}^{1}=\mathrm{Ph}$

L8: $R^{1}=B n$

Supplementary Table 2. Screening results on Ni-source<smiles>N#Cc1ccc(I)cc1</smiles>

$2 a$

(0.1 $\mathrm{mmol})$

$1 a$

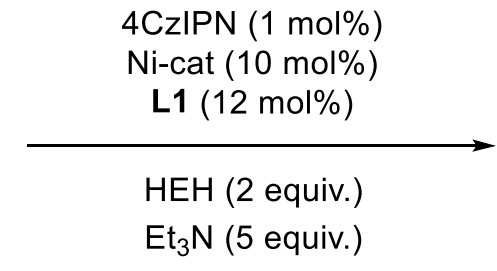

CPME (0.05 M) ( 1.5 equiv.)

blue LEDs (30W, 450-455nm)<smiles>N#Cc1ccc([C@H](CCc2ccccc2)C(F)(F)F)cc1</smiles>

$3 a$ $20^{\circ} \mathrm{C}-30^{\circ} \mathrm{C}$

\begin{tabular}{llll}
\hline Entry & Ni-cat & Yield $(\%)^{[\mathrm{a}]}$ & Er \\
\hline
\end{tabular}




\begin{tabular}{lccc}
\hline $\mathbf{1}$ & $\mathrm{NiBr} 2(\mathrm{DME})$ & $82 \%$ & $93: 7$ \\
$\mathbf{2}$ & $\mathrm{NiBr}_{2}$ & $8 \%$ & $91: 9$ \\
$\mathbf{3}$ & $\mathrm{Ni}(\mathrm{cod})_{2}$ & $45 \%$ & $93: 7$ \\
$\mathbf{4}$ & $\mathrm{NiCl}_{2}(\mathrm{DME})$ & $40 \%$ & $92.5: 7.5$ \\
$\mathbf{5}$ & $\mathrm{NiI}_{2}$ & $50 \%$ & $91: 9$ \\
\hline
\end{tabular}

[a] GC yield using $n$-dodecane as the internal standard. Reaction run at a $0.10 \mathrm{mmol}$ scale.

Supplementary Table 3. Screening results on solvents<smiles>N#Cc1ccc(I)cc1</smiles>

$2 a$

(0.1 mmol)

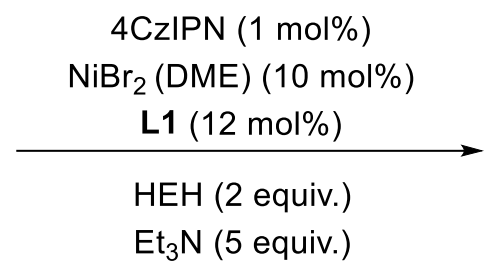

Solvent $(0.05 \mathrm{M})$<smiles>N#Cc1ccc(C(CCc2ccccc2)C(F)(F)F)cc1</smiles>

$3 a$

1a blue LEDs (30W, 450-455nm) $20^{\circ} \mathrm{C}-30^{\circ} \mathrm{C}$

\begin{tabular}{cccc}
\hline Entry & Solvent & Yield(\%) $)^{[a]}$ & Er \\
\hline $\mathbf{1}$ & DMA & $20 \%$ & $94: 6$ \\
$\mathbf{2}$ & DME & $64 \%$ & $93: 7$ \\
$\mathbf{3}$ & Dioxane & $43 \%$ & $93: 7$ \\
$\mathbf{4}$ & THF & $57 \%$ & $91: 9$ \\
$\mathbf{5}$ & ACN & $21 \%$ & $91: 9$ \\
$\mathbf{6}$ & DCE & $52 \%$ & $89.5: 10.5$ \\
$\mathbf{7}$ & TBME & $82 \%$ & $92.5: 7.5$ \\
$\mathbf{8}$ & CPME & $82 \%$ & $93: 7$ \\
$\mathbf{9}$ & TBME/DMA (v/v $=5 / 1)$ & n.d. & -- \\
$\mathbf{1 0}$ & CPME/DMA $(\mathrm{v} / \mathrm{v}=5 / 1)$ & n.d. & -- \\
\hline
\end{tabular}

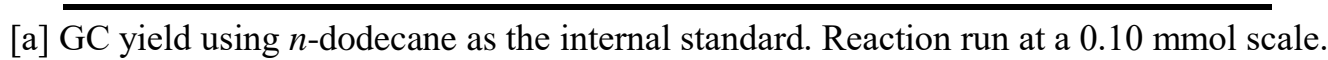

Supplementary Table 4. Screening results on base.<smiles>N#Cc1ccc(I)cc1</smiles>

$2 a$

(0.1 $\mathrm{mmol})$

$1 a$ ( 1.5 equiv.)

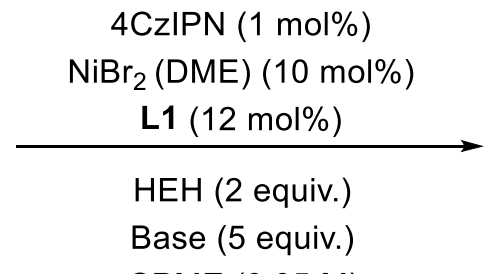

CPME (0.05 M)<smiles>N#Cc1ccc([C@H](CCc2ccccc2)C(F)(F)F)cc1</smiles>

$3 a$

\begin{tabular}{cccc}
\hline Entry & Base & Yield(\%) & Er \\
\hline $\mathbf{1}$ & $\mathrm{Et}{ }_{3} \mathrm{~N}$ & $82 \%$ & $93: 7$ \\
$\mathbf{2}$ & $\mathrm{DIPA}$ & $52 \%$ & $92.5: 7.5$ \\
$\mathbf{3}$ & $\mathrm{DIPEA}$ & $14 \%$ & $92.5: 7.5$ \\
$\mathbf{4}$ & $\mathrm{Cy}_{2} \mathrm{NMe}$ & $52 \%$ & $92.5: 7.5$ \\
\hline
\end{tabular}




\begin{tabular}{cccc}
\hline $\mathbf{5}$ & $\mathrm{Cy}_{2} \mathrm{NH}$ & $60 \%$ & $92.5: 7.5$ \\
$\mathbf{6}$ & $\mathrm{DBACO}$ & n.d. & -- \\
$\mathbf{7}$ & $\mathrm{DBU}$ & n.d. & -- \\
$\mathbf{8}$ & $\mathrm{Et}_{2} \mathrm{NH}$ & $27 \%$ & $92.5: 7.5$ \\
$\mathbf{9}$ & $\mathrm{K}_{3} \mathrm{PO}_{4}$ & $16 \%$ & $90.5: 9.5$ \\
$\mathbf{1 0}$ & $\mathrm{Na}_{2} \mathrm{CO}_{3}$ & n.d. & -- \\
\hline
\end{tabular}

[a] GC yield using $n$-dodecane as the internal standard. Reaction run at a $0.10 \mathrm{mmol}$ scale.

DIPEA = Ethyldiisopropylamine

DIPA = Diisopropylamine

Supplementary Table 5. Screening results on time.

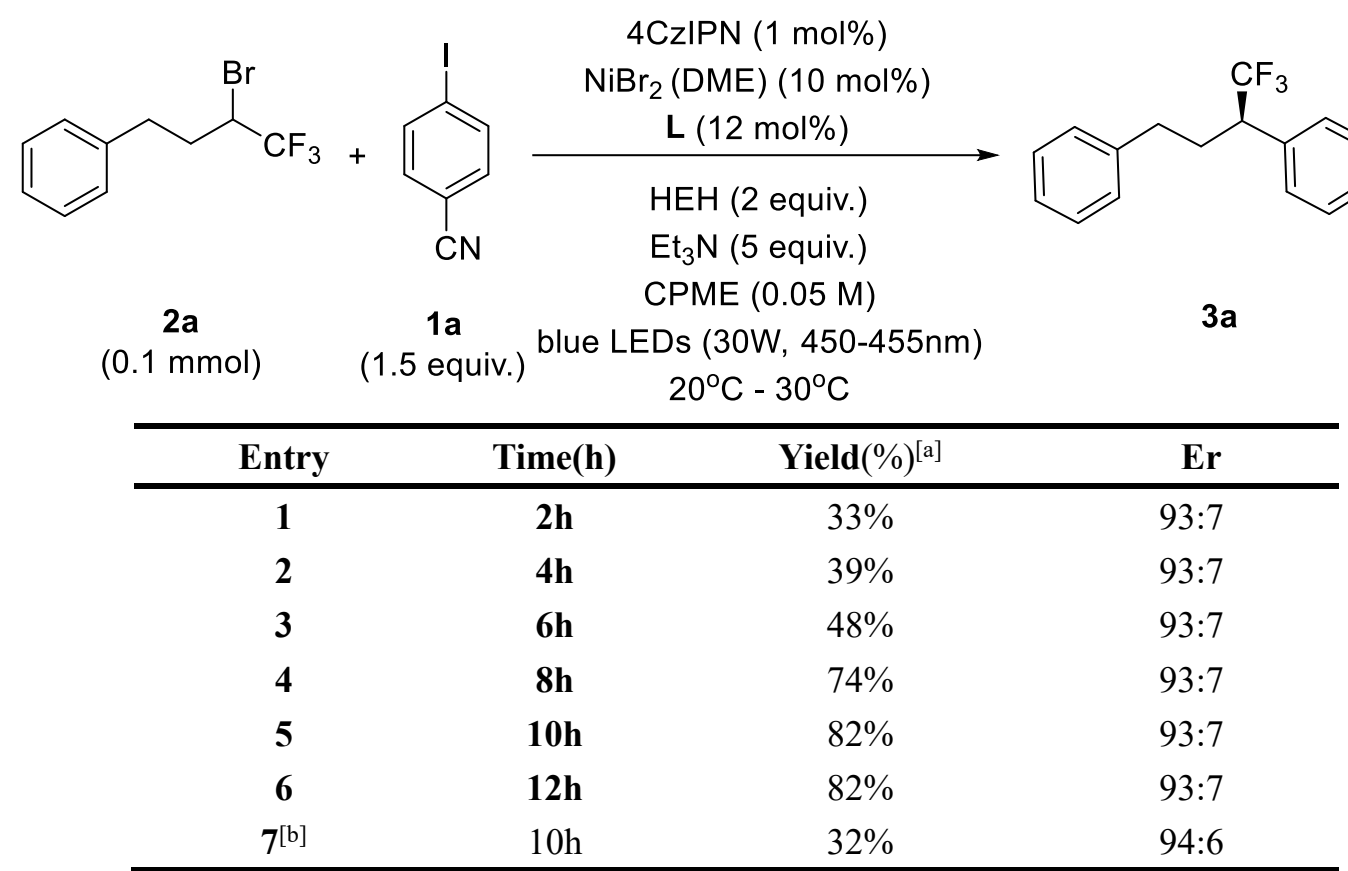

[a] GC yield using $n$-dodecane as the internal standard. [b] Reactions were irradiated with two 10 W blue LED lamps (450 - 455nm) and used low temperature stirred reaction bath to keep the reaction temperature at $-10^{\circ} \mathrm{C}$. Reaction run at a $0.10 \mathrm{mmol}$ scale.

Supplementary Table 6. Control reactions<smiles>N#Cc1ccc(I)cc1</smiles>

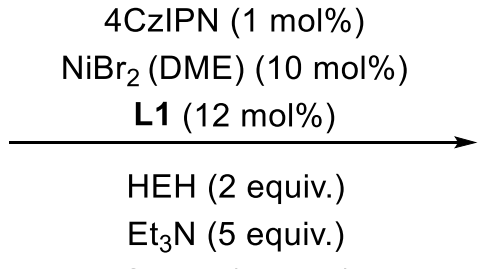

CPME $(0.05 \mathrm{M})$

$1 \mathrm{a}$

(1.5 equiv.)

blue LEDs (30W, 450-455nm)<smiles>N#Cc1ccc(C(CCc2ccccc2)C(F)(F)F)cc1</smiles>

$3 a$

$(0.1 \mathrm{mmol})$

$$
20^{\circ} \mathrm{C}-30^{\circ} \mathrm{C}
$$

\begin{tabular}{cccc}
\hline Entry & Changes & Yield $(\%)^{[\mathrm{a}]}$ & Er \\
\hline $\mathbf{1}$ & No changes & $82 \%$ & $93: 7$ \\
\hline
\end{tabular}




\begin{tabular}{cccc}
\hline $\mathbf{2}$ & {$\left[\operatorname{Ir}\left(\mathrm{dF}\left(\mathrm{CF}_{3}\right) \text { ppy }\right)_{2}(\mathrm{dtbbpy})\right] \mathrm{PF}_{6}$} & $46 \%$ & $93: 7$ \\
$\mathbf{3}$ & $\mathrm{Ru}(\mathrm{bpy})_{3} \mathrm{Cl}_{2} \cdot 6 \mathrm{H}_{2} \mathrm{O}$ & n.d. & -- \\
$\mathbf{4}$ & {$\left[\operatorname{Ir}\left(\mathrm{dF}\left(\mathrm{CF}_{3}\right) \mathrm{ppy}_{2}(\mathrm{bpy})\right] \mathrm{PF}_{6}\right.$} & $18 \%$ & $92.5: 7.5$ \\
$\mathbf{5}$ & {$\left[\operatorname{Ir}(\mathrm{ppy})_{3}\right] \mathrm{PF}_{6}$} & $22 \%$ & $93: 7$ \\
$\mathbf{6}$ & $4 \mathrm{CzTPN}$ & $15 \%$ & $93: 7$ \\
$\mathbf{7}$ & No HEH & n.d. & -- \\
$\mathbf{8}$ & No TEA & n.d. & -- \\
$\mathbf{9}$ & No light & n.d. & -- \\
$\mathbf{1 0}$ & No 4CzIPN & n.d. & -- \\
$\mathbf{1 1}$ & No Ni & n.d. & -- \\
$\mathbf{1 2}$ & No ligand & n.d. & -- \\
\hline
\end{tabular}

[a] GC yield using $n$-dodecane as the internal standard. Reaction run at a $0.10 \mathrm{mmol}$ scale. 


\section{General Procedures}

\subsection{General Procedure for arylation of $\alpha$-Trifluoromethyl Aliphatic Compounds}

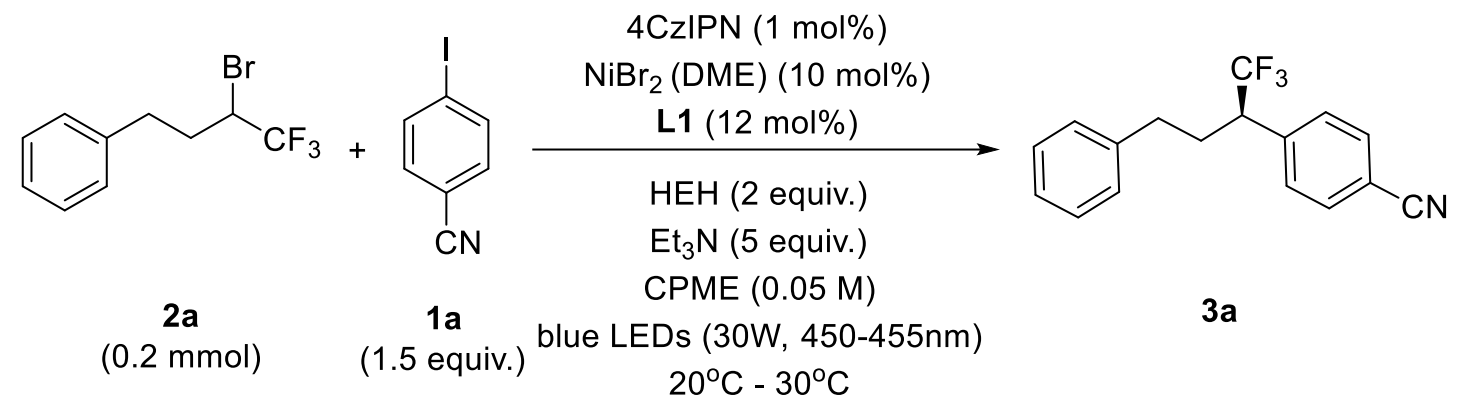

An oven-dried 10-mL Schlenk tube containing a Teflon stir bar was charged with 4CzIPN (0.002 mmol, 1 mol\%), NiBr 2 (DME) (0.02 mmol, $10 \mathrm{~mol} \%), \mathrm{L1}(0.024$ mmol, $12 \mathrm{~mol} \%)$, HEH ( $0.4 \mathrm{mmol}, 2$ equiv.), $\mathrm{Et}_{3} \mathrm{~N}$ ( $1.0 \mathrm{mmol}, 5$ equiv.). Then the tube was sealed with a septum and taken out of the $\mathrm{N}_{2}$-filled glovebox. CPME (4 mL, $0.05 \mathrm{M}$ ) were added via syringe under $\mathrm{N}_{2}$ atmosphere and the reaction mixture was stirred for $1 \mathrm{~h}$ at room temperature. Then $\mathbf{2 a}(0.2 \mathrm{mmol})$ and aryl halide $1 \mathbf{a}(0.30$ mmol, 1.5 equiv.) were added via micro-syringes. Once added, the tube was sealed again, and the reaction mixture was stirred and irradiated under blue light $(\lambda=450$ $455 \mathrm{~nm}$ ) for 8-10 hours, while the temperature was controlled at approximately $20{ }^{\circ} \mathrm{C}$ - $30{ }^{\circ} \mathrm{C}$ by cooling with fans and air-conditioner. Upon completed, the mixture was quenched with water and diluted with EtOAc. The aqueous solution was extracted with EtOAc three times. The combined organic layers were dried over anhydrous $\mathrm{Na}_{2} \mathrm{SO}_{4}$, filtered through Celite, and concentrated in vacuo. The residues were purified by silica gel column chromatography with a gradient eluent of petroleum ether/ethyl acetate affording the product 3a (43.4 mg, 75\% yield, 93:7 er). The er value was determined by HPLC analysis.

\subsection{Scale-up reactions}

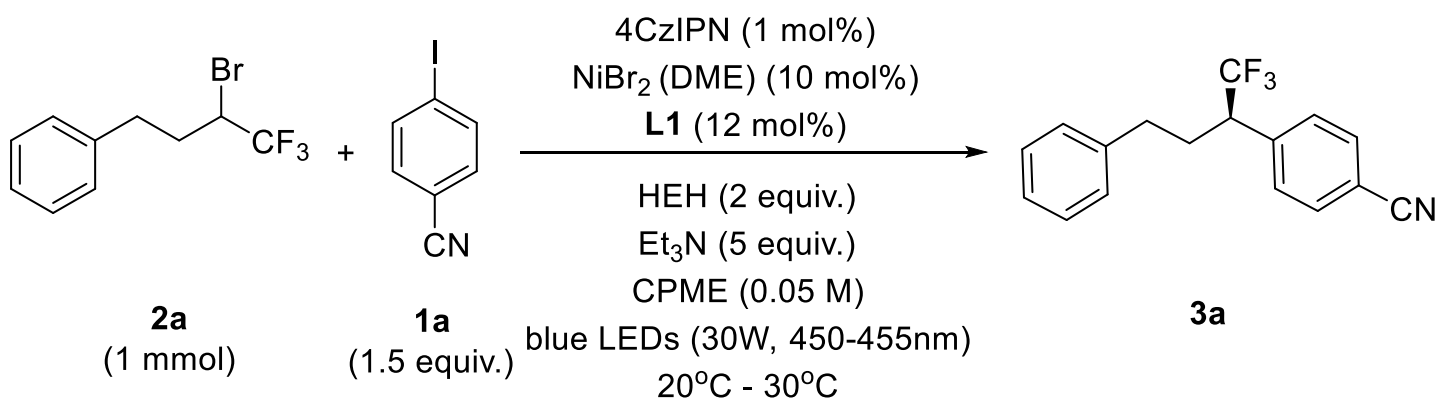

An oven-dried 50-mL Schlenk tube containing a Teflon stir bar was charged with 4CzIPN (0.01 mmol, $7.9 \mathrm{mg}, 1 \mathrm{~mol} \%$ ), NiBr 2 (DME) (0.1 mmol, $30.8 \mathrm{mg}, 10 \mathrm{~mol} \%$ ), L1 (0.12 mmol, $58.3 \mathrm{mg}, 12 \mathrm{~mol} \%)$, HEH (2.0 mmol, $504 \mathrm{mg}, 2$ equiv.), Et $3 \mathrm{~N}$ (5.0 mmol, $505 \mathrm{mg}, 5$ equiv.). Then the tube was sealed with a septum and taken out of the $\mathrm{N}_{2}$-filled glovebox. CPME $(20 \mathrm{~mL})$ were added via syringe under $\mathrm{N}_{2}$ atmosphere and the reaction mixture was stirred for $1 \mathrm{~h}$ at room temperature. Then aryl halide $\mathbf{1 a}(1.5$ mmol, $343.5 \mathrm{mg}, 1.5$ equiv. $)$ and $\mathbf{2 a}(1.0 \mathrm{mmol}, 266 \mathrm{mg})$ were added via 
micro-syringes. Once added, the tube was sealed again, and the reaction mixture was stirred and irradiated under blue light $(\lambda=450-455 \mathrm{~nm})$ for 10 hours, while the temperature was controlled at approximately $20{ }^{\circ} \mathrm{C}$ by cooling with fans and air-conditioner. Upon completed, the mixture was diluted with EtOAc and quenched with water. The aqueous solution was extracted with EtOAc three times. The combined organic layers were dried over anhydrous $\mathrm{Na}_{2} \mathrm{SO}_{4}$, filtered through Celite, and concentrated in vacuo. The residues were purified by silica gel column chromatography with a gradient eluent of petroleum ether/ethyl acetate affording the product 3a (198 mg, 68\%, 93:7 er). The er value was determined by HPLC analysis using the relative alcohol after oxidation of the product. 


\section{Mechanism Studies}

\subsection{Competing Reactions}<smiles>FC(F)(F)C(Br)CCc1ccccc1</smiles>

2a

$(0.2 \mathrm{mmol})$<smiles>N#Cc1ccc(I)cc1</smiles>

$1 a$

(0.3 mmol)

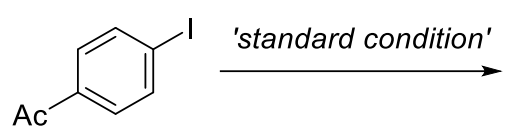

$1 d$

(0.3 mmol)<smiles>[R]c1ccc([C@H](CCc2ccccc2)C(F)(F)F)cc1</smiles>

$3 \mathbf{3}(59 \%, 93: 7$ er $)$ 3d (6\%, 92:8 er) $\mathbf{R}=\mathrm{CN}$ or $\mathrm{Ac}$

An oven-dried 10-mL Schlenk tube containing a Teflon stir bar was charged with 4CzIPN (0.002 mmol, 1 mol\%), NiBr 2 (DME) (0.02 mmol, $10 \mathrm{~mol} \%), \mathrm{L1}(0.024$ mmol, $12 \mathrm{~mol} \%$ ), HEH ( $0.4 \mathrm{mmol}, 2$ equiv.), $\mathrm{Et}_{3} \mathrm{~N}$ ( $1.0 \mathrm{mmol}, 5$ equiv.). Then the tube was sealed with a septum and taken out of the $\mathrm{N}_{2}$-filled glovebox. CPME ( $4 \mathrm{~mL}$, $0.05 \mathrm{M}$ ) were added via syringe under $\mathrm{N}_{2}$ atmosphere and the reaction mixture was stirred for $1 \mathrm{~h}$ at room temperature. Then $\mathbf{2 a}(0.2 \mathrm{mmol})$ and $1 \mathrm{a}(0.30 \mathrm{mmol}, 1.5$ equiv.), 1d ( $0.30 \mathrm{mmol}, 1.5$ equiv.) were added via micro-syringes. Once added, the tube was sealed again, and the reaction mixture was stirred and irradiated under blue light $(\lambda=450-455 \mathrm{~nm})$ for $8-10$ hours, while the temperature was controlled at approximately $20{ }^{\circ} \mathrm{C}-30{ }^{\circ} \mathrm{C}$ by cooling with fans and air-conditioner. Upon completed, the mixture was quenched with water and diluted with EtOAc. The aqueous solution was extracted with EtOAc three times. The combined organic layers were dried over anhydrous $\mathrm{Na}_{2} \mathrm{SO}_{4}$, filtered through Celite, and concentrated in vacuo. The residues were purified by silica gel column chromatography with a gradient eluent of petroleum ether/ethyl acetate affording the product 3a $(34.1 \mathrm{mg}, 59 \%$ yield, 93:7 er) and 3d (3.7 mg, 6\% yield, 92:8 er). The er value was determined by HPLC analysis.<smiles>FC(F)(F)C(Br)CCc1ccccc1</smiles>

2a $(0.2 \mathrm{mmol})$<smiles>N#Cc1ccc(I)cc1</smiles>

$1 \mathrm{a}$ (0.3 mmol)

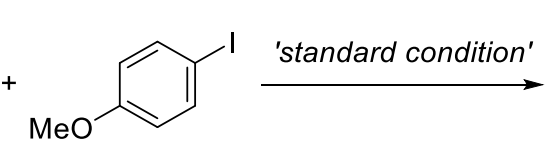

$1 \mathrm{~h}$

$(0.3 \mathrm{mmol})$<smiles>[R]c1ccc([C@H](CCc2ccccc2)C(F)(F)F)cc1</smiles>

3a $(55 \%, 93: 7$ er $)$ $3 \mathrm{~h}(<5 \%$, by GC) $\mathbf{R}=\mathrm{CN}$ or $\mathrm{OMe}$

An oven-dried 10-mL Schlenk tube containing a Teflon stir bar was charged with 4CzIPN (0.002 mmol, 1 mol\%), NiBr 2 (DME) (0.02 mmol, $10 \mathrm{~mol} \%), \mathrm{L1}(0.024$ mmol, 12 mol\%), HEH (0.4 mmol, 2 equiv.), $\mathrm{Et}_{3} \mathrm{~N}$ (1.0 mmol, 5 equiv.). Then the tube was sealed with a septum and taken out of the $\mathrm{N}_{2}$-filled glovebox. CPME ( $4 \mathrm{~mL}$, $0.05 \mathrm{M})$ were added via syringe under $\mathrm{N}_{2}$ atmosphere and the reaction mixture was stirred for $1 \mathrm{~h}$ at room temperature. Then $\mathbf{2 a}(0.2 \mathrm{mmol}), \mathbf{1 a}(0.30 \mathrm{mmol}, 1.5$ equiv. $)$ 
and $\mathbf{1 h}(0.30 \mathrm{mmol}, 1.5$ equiv. $)$ were added via micro-syringes. Once added, the tube was sealed again, and the reaction mixture was stirred and irradiated under blue light $(\lambda=450-455 \mathrm{~nm})$ for $8-10$ hours, while the temperature was controlled at approximately $20{ }^{\circ} \mathrm{C}-30{ }^{\circ} \mathrm{C}$ by cooling with fans and air-conditioner. Upon completed, the mixture was quenched with water and diluted with EtOAc before the internal standard ( $n$-dodecane) were added. The yield of $3 \mathrm{~h}$ was determined by GC analysis. Then the aqueous solution was extracted with EtOAc three times. The combined organic layers were dried over anhydrous $\mathrm{Na}_{2} \mathrm{SO}_{4}$, filtered through Celite, and concentrated in vасио. The residues were purified by silica gel column chromatography with a gradient eluent of petroleum ether/ethyl acetate affording the product 3a (31.8 mg, 55\% yield, 93:7 er). The er value was determined by HPLC analysis.

\subsection{Mechanistic Studies Experiments}

\section{Control Experiment with TEMPO}

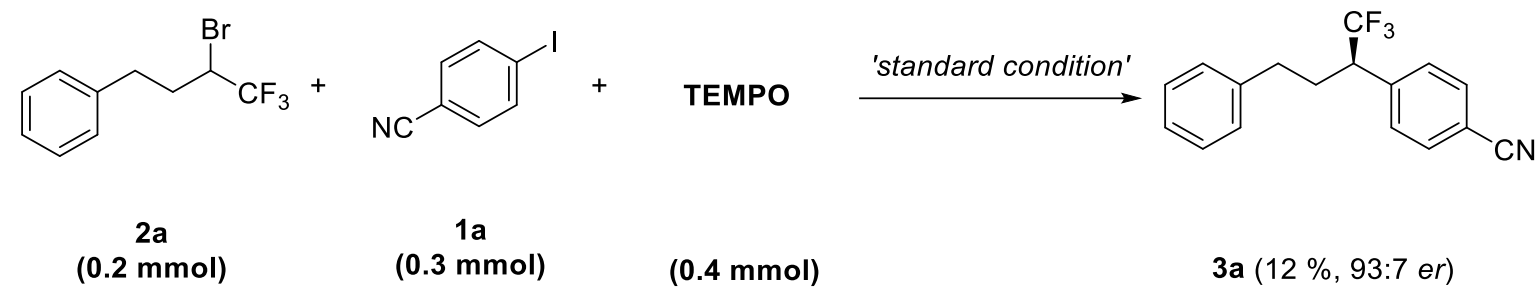

An oven-dried 10-mL Schlenk tube containing a Teflon stir bar was charged with 4CzIPN (0.002 mmol, $1 \mathrm{~mol} \%), \mathrm{NiBr}_{2}$ (DME) (0.02 mmol, $\left.10 \mathrm{~mol} \%\right), \mathrm{L1}$ (0.024 mmol, 12 mol\%), HEH ( 0.4 mmol, 2 equiv.), $\mathrm{Et}_{3} \mathrm{~N}$ (1.0 mmol, 5 equiv.). Then the tube was sealed with a septum and taken out of the $\mathrm{N}_{2}$-filled glovebox. CPME ( $4 \mathrm{~mL}$, $0.05 \mathrm{M}$ ) were added via syringe under $\mathrm{N}_{2}$ atmosphere and the reaction mixture was stirred for $30 \mathrm{~min}$ at room temperature. Then $\mathbf{2 a}(0.2 \mathrm{mmol}), \mathbf{1 a}(0.30 \mathrm{mmol}, 1.5$ equiv.) and TEMPO (0.40 mmol, 2 equiv.) were added to the resulting mixture. Once added, the tube was sealed again, and the reaction mixture was stirred and irradiated under blue light $(\lambda=450-455 \mathrm{~nm})$ for $8-10$ hours, while the temperature was controlled at approximately $20{ }^{\circ} \mathrm{C}-30{ }^{\circ} \mathrm{C}$ by cooling with fans and air-conditioner. Upon completed, the mixture was quenched with water and diluted with EtOAc before the internal standard ( $n$-dodecane) were added. Then the aqueous solution was extracted with EtOAc three times. The combined organic layers were dried over anhydrous $\mathrm{Na}_{2} \mathrm{SO}_{4}$, filtered through Celite, and concentrated in vacuo. The residues were purified by silica gel column chromatography with a gradient eluent of petroleum ether/ethyl acetate affording the product 3a (7 mg, $12 \%$ yield, 93:7 er). The er value was determined by HPLC analysis. 


\section{Cyclization Reactions}

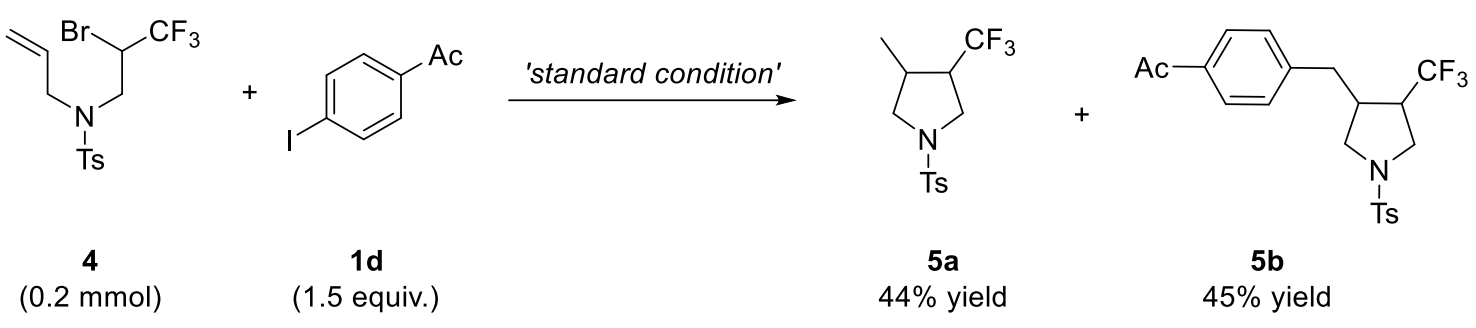

An oven-dried 10-mL Schlenk tube containing a Teflon stir bar was charged with 4CzIPN (0.002 mmol, $1 \mathrm{~mol} \%), \mathrm{NiBr}_{2}$ (DME) (0.02 mmol, $\left.10 \mathrm{~mol} \%\right), \mathrm{L1}(0.024$ mmol, $12 \mathrm{~mol} \%$ ), HEH ( $0.4 \mathrm{mmol}, 2$ equiv.), $\mathrm{Et}_{3} \mathrm{~N}$ (1.0 mmol, 5 equiv.). Then the tube was sealed with a septum and taken out of the $\mathrm{N}_{2}$-filled glovebox. CPME $(4 \mathrm{~mL}$, $0.05 \mathrm{M})$ were added via syringe under $\mathrm{N}_{2}$ atmosphere and the reaction mixture was stirred for $1 \mathrm{~h}$ at room temperature. Then $4(0.2 \mathrm{mmol})$ and $\mathbf{1 d}(0.30 \mathrm{mmol}, 1.5$ equiv.) were added to the resulting mixture. Once added, the tube was sealed again, and the reaction mixture was stirred and irradiated under blue light $(\lambda=450-455 \mathrm{~nm})$ for 10 hours, while the temperature was controlled at approximately $20{ }^{\circ} \mathrm{C}-30{ }^{\circ} \mathrm{C}$ by cooling with fans and air-conditioner. Upon completed, the mixture was quenched with water and diluted with EtOAc. Then the aqueous solution was extracted with EtOAc three times. The combined organic layers were dried over anhydrous $\mathrm{Na}_{2} \mathrm{SO}_{4}$, filtered through Celite, and concentrated in vacuo. The residues were purified by silica gel column chromatography with a gradient eluent of petroleum ether/ethyl acetate affording the product $\mathbf{5 a}$ ( $27 \mathrm{mg}, 44 \%$ yield) and $\mathbf{5 b}$ (38 $\mathrm{mg}, 45 \%$ yield).

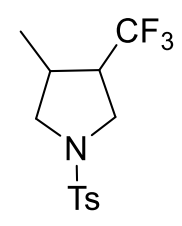

$5 a$

${ }^{1} \mathrm{H}$ NMR (600 MHz, $\left.\mathrm{CDCl}_{3}\right) \delta 7.72-7.71(\mathrm{~m}, 2 \mathrm{H}), 7.35(\mathrm{~d}, J=7.9 \mathrm{~Hz}, 2 \mathrm{H}), 3.59$ (dd, $J=10.9,8.3 \mathrm{~Hz}, 1 \mathrm{H}), 3.48(\mathrm{dd}, J=9.7,6.9 \mathrm{~Hz}, 1 \mathrm{H}), 3.40(\mathrm{dd}, J=10.9,6.4 \mathrm{~Hz}, 1 \mathrm{H})$, $2.96(\mathrm{dd}, J=9.7,6.9 \mathrm{~Hz}, 1 \mathrm{H}), 2.79-2.70(\mathrm{~m}, 1 \mathrm{H}), 2.50-2.43(\mathrm{~m}, 1 \mathrm{H}), 2.45(\mathrm{~s}, 3 \mathrm{H})$, $1.01(\mathrm{dd}, J=7.2,2.0 \mathrm{~Hz}, 3 \mathrm{H}) ;{ }^{13} \mathrm{C}$ NMR $(151 \mathrm{MHz}$, Chloroform- $d$ ) $\delta 143.8,133.2$, $129.8,127.5,126.2$ (q, $J=280.9 \mathrm{~Hz}), 54.2,46.5$ (d, $J=3.0 \mathrm{~Hz}), 45.1$ (q, $J=27.2 \mathrm{~Hz})$, 33.7, 21.6, 13.2; ${ }^{19} \mathrm{~F}$ NMR (565 MHz, Chloroform- $d$ ) $\delta-65.5$; HRMS (ESI) m/z: $[\mathrm{M}+\mathrm{H}]^{+}$calcd for $\mathrm{C}_{13} \mathrm{H}_{17} \mathrm{~F}_{3} \mathrm{NO}_{2} \mathrm{~S}^{+}: 308.0927$; found: 308.0938 . 


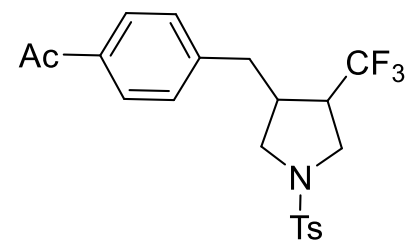

$5 b$

${ }^{1} \mathrm{H}$ NMR (600 MHz, $\left.\mathrm{CDCl}_{3}\right) \delta 7.90-7.89(\mathrm{~m}, 2 \mathrm{H}), 7.68-7.67(\mathrm{~m}, 2 \mathrm{H}), 7.35(\mathrm{~d}, J=$ $8.0 \mathrm{~Hz}, 2 \mathrm{H}), 7.18(\mathrm{~d}, J=8.0 \mathrm{~Hz}, 2 \mathrm{H}), 3.61(\mathrm{dd}, J=11.0,8.3 \mathrm{~Hz}, 1 \mathrm{H}), 3.54(\mathrm{dd}, J=$ $11.1,5.7 \mathrm{~Hz}, 1 \mathrm{H}), 3.19(\mathrm{dd}, J=9.9,6.7 \mathrm{~Hz}, 1 \mathrm{H}), 3.03-2.99(\mathrm{~m}, 2 \mathrm{H}), 2.93-2.88(\mathrm{~m}$, $1 \mathrm{H}), 2.68-2.62(\mathrm{~m}, 1 \mathrm{H}), 2.61(\mathrm{~s}, 3 \mathrm{H}), 2.61-2.55(\mathrm{~m}, 1 \mathrm{H}), 2.46(\mathrm{~s}, 3 \mathrm{H}) .{ }^{13} \mathrm{C} \mathrm{NMR}$ (151 MHz, Chloroform- $d$ ) $\delta$ 197.6, 144.4, 144.0, 135.8, 133.3, 129.8, 128.9, 128.8, 128.5 (q, $J=279.4 \mathrm{~Hz}), 127.4,51.0,46.7$ (d, $J=3.4 \mathrm{~Hz}), 44.8$ (q, $J=27.2 \mathrm{~Hz}), 40.9$, 33.6, 26.6, 21.6; ${ }^{19} \mathrm{~F}$ NMR (565 MHz, Chloroform- $d$ ) $\delta$ - 65.1; HRMS (ESI) m/z: $[\mathrm{M}+\mathrm{H}]^{+}$calcd for $\mathrm{C}_{21} \mathrm{H}_{23} \mathrm{~F}_{3} \mathrm{NO}_{3} \mathrm{~S}^{+}$: 426.1345 ; found: 426.1369 .

\subsection{Light On-Off Experiments}<smiles>N#Cc1ccc(I)cc1</smiles>

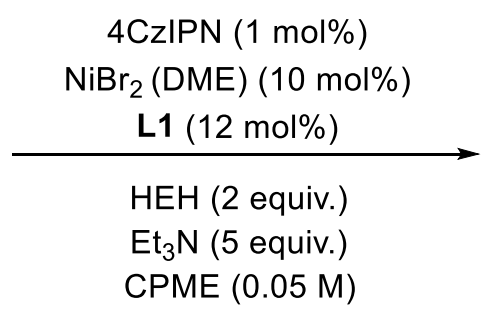

blue LEDs (30W, 450-455nm) $20^{\circ} \mathrm{C}-30^{\circ} \mathrm{C}$

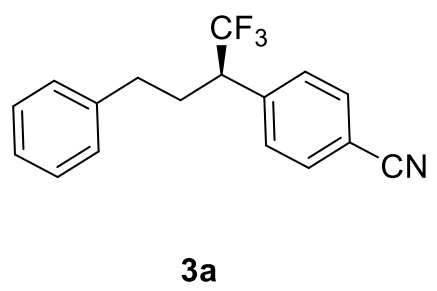

$(0.2 \mathrm{mmol})$ (1.5 equiv.)

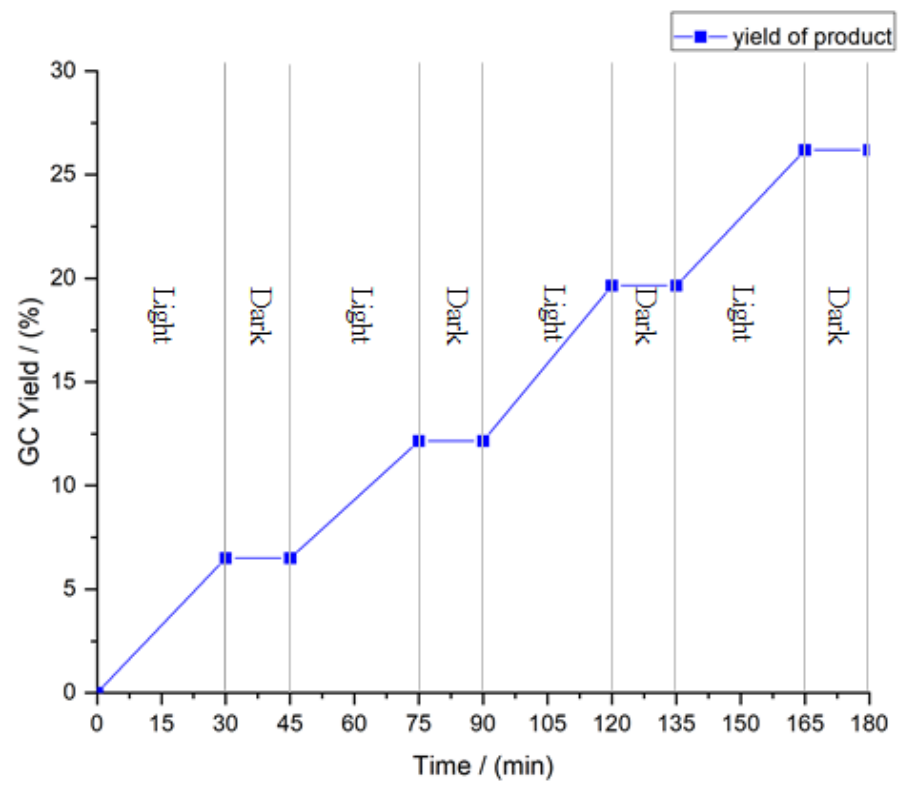

Figure S2. Light on-off experiments

The yield of 3a was determined by GC analysis $n$-dodecane as the internal standard. 


\subsection{Stern-Volmer Quenching Studies}

The stern-volmer Fluorescence experiments were conducted using Hitachi Instrument F-7000 spectrofluorometer with a screw-top quartz cuvette (45 mm x 10 $\mathrm{mm} \times 10 \mathrm{~mm}$ ).

CPME solution was sparged with $\mathrm{N}_{2}$ for at least 1 hour and then transferred into $\mathrm{N}_{2}$-filled glovebox. All the solutions were prepared in $\mathrm{N}_{2}$-filled glovebox and the general procedures were as follows:

\section{Photocatalyst solution}

To an oven dried $100 \mathrm{~mL}$ flask 4CzIPN ( $\left.1 \mathrm{mg}, 1.3 \times 10^{-3} \mathrm{mmol}\right)$ was dissolved in $90 \mathrm{~mL}$ CPME to freshly prepare an $1.41 \times 10^{-5} \mathrm{M} 4 \mathrm{CzIPN}$ solution.

\section{$\alpha$-trifluoromethyl aliphatic compounds $(2 a)$ solution}

To an oven dried $5 \mathrm{~mL}$ vail $\mathbf{2 a}(106.4 \mathrm{mg}, 0.4 \mathrm{mmol})$ was dissolved in $1 \mathrm{~mL}$ CPME to freshly prepare a $4.0 \mathrm{M}$ solution of $\mathbf{2 a}$.

The solutions were irradiated at $378 \mathrm{~nm}$, and the emission were measured from $450 \mathrm{~nm}$ to $700 \mathrm{~nm}$. The emission intensities were recorded at the maximum wavelength $\left(\lambda_{\mathrm{em}}=507 \mathrm{~nm}\right)$. The Stern-Volmer Quenching plots of $4 \mathrm{CzIPN}$ solution were obtained by $\mathbf{2 a}$ quencher respectively.

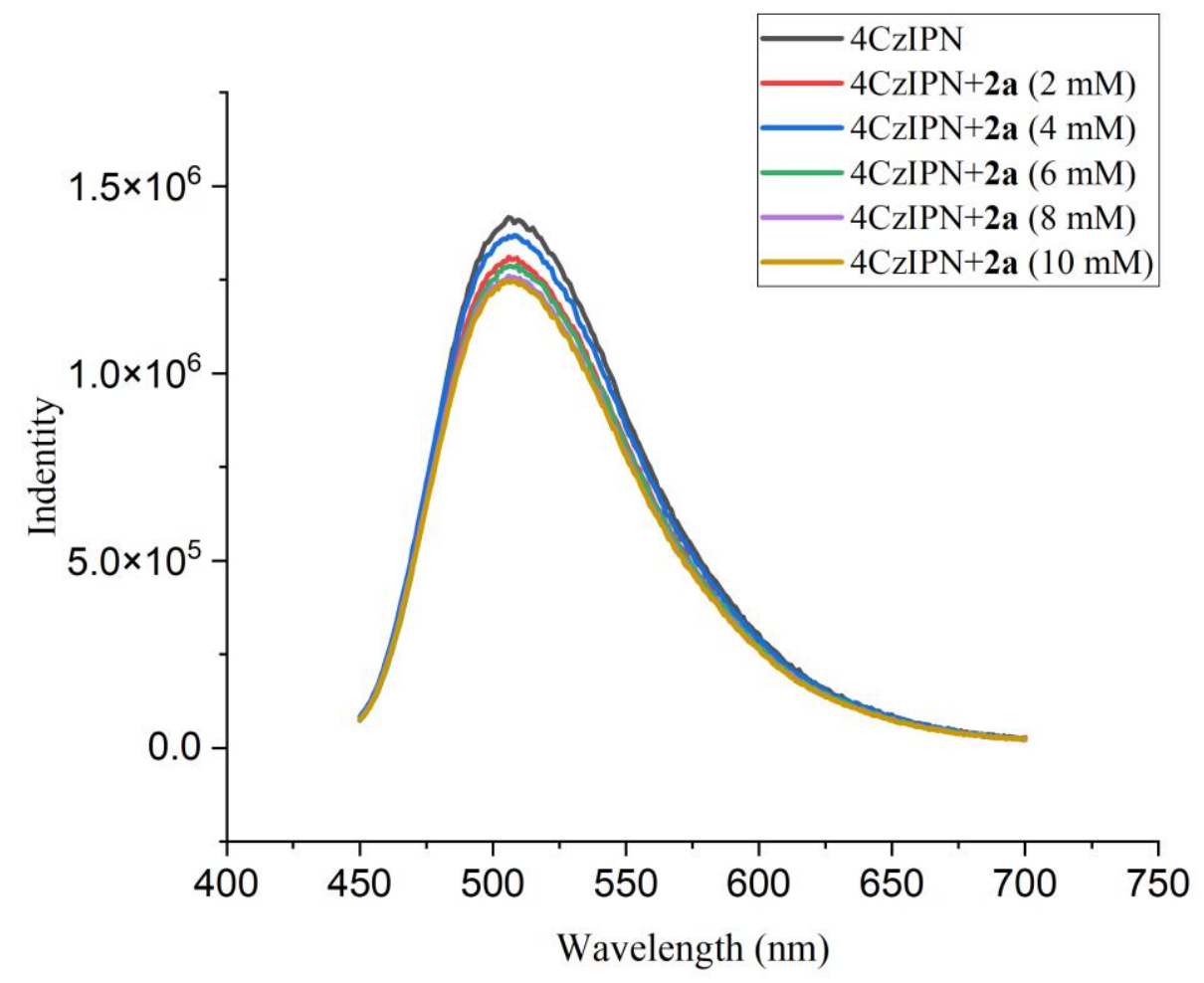




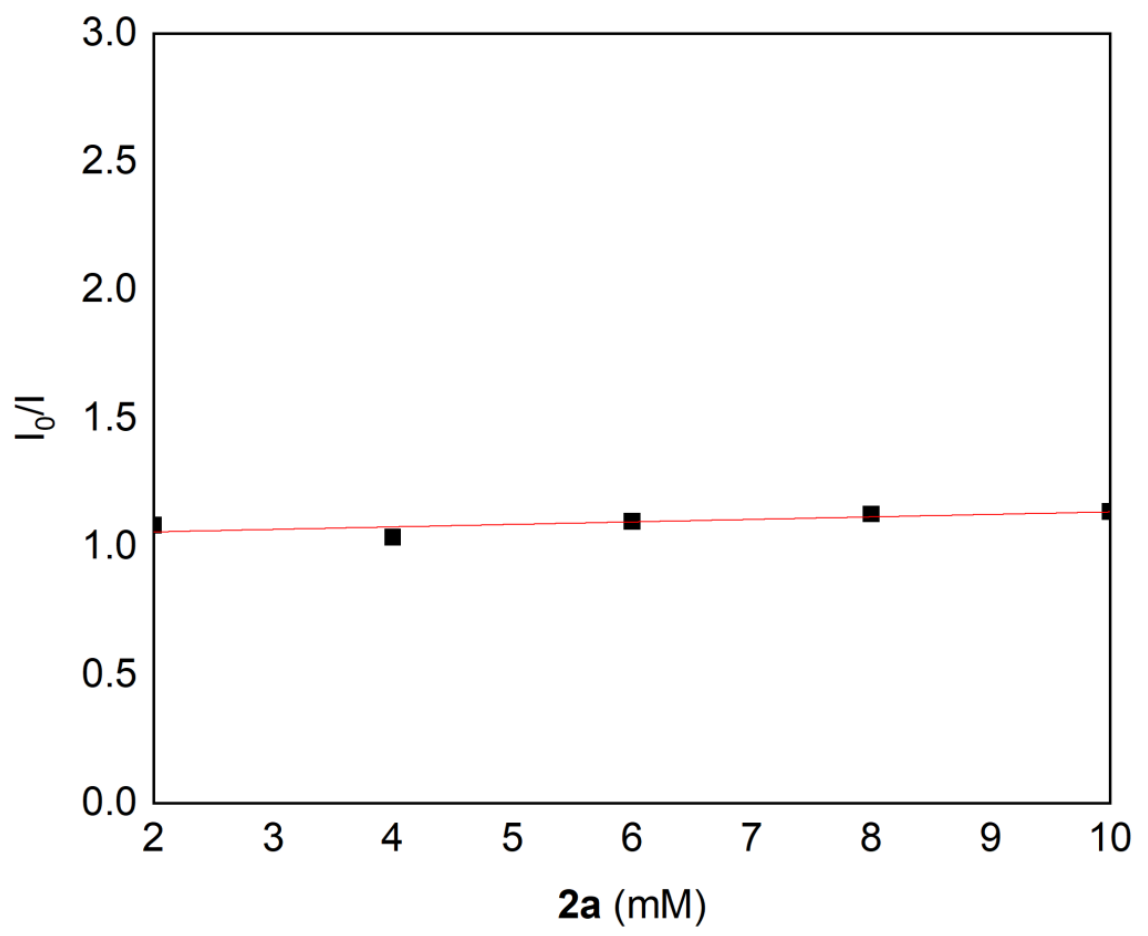

Figure S3. Fluorescence quenching experiment: (up) Plot of 4CzIPN emission quenching by $\alpha$-trifluoromethyl aliphatic compounds (2a); (down) Stern Volmer Relationship for $\alpha$-trifluoromethyl aliphatic compounds (2a). 


\section{Synthesis of the starting materials}<smiles>FC(F)(F)C(Br)CCc1ccccc1</smiles>

$2 a$<smiles>OCCCC(Br)C(F)(F)F</smiles>

$2 t$<smiles>CC(Oc1ccc(C(F)(F)F)cc1)C(Br)C(F)(F)F</smiles>

$2 x$<smiles>CC(Oc1ccc2c(c1)CC[C@H]1[C@@H]3CCC(=O)[C@@]3(C)CC[C@@H]21)C(F)(F)F</smiles>

2dd<smiles>O=C(OCCCC(Br)C(F)(F)F)OCc1ccccc1</smiles>

$2 q$<smiles>CCCCCCC(Br)C(F)(F)F</smiles>

2v<smiles>Cc1ncsc1C(=O)OCC(C(F)(F)F)C(F)(F)Br</smiles>

$2 y$<smiles>COc1ccc2c(c1)c(CC(=O)OCC(C)C(F)(F)F)c(C)n2C(=O)c1ccc(Cl)cc1</smiles>

2ee<smiles>O=C1c2ccccc2C(=O)N1CCC(Br)C(F)(F)F</smiles>

$2 s$<smiles>FC(F)(F)c1ccc(COC(Br)C(F)(F)F)cc1</smiles>

$2 \mathbf{w}$<smiles>O=C(COC(=O)C(Br)C(F)(F)F)c1ccccc1F</smiles>

$2 z$<smiles>C=CCN(CC(Br)C(F)(F)F)S(=O)(=O)c1ccc(C)cc1</smiles>

4

The $\alpha$-trifluoromethyl secondary alkyl bromides compounds $\mathbf{2 a}, \mathbf{2 q}, \mathbf{2 s}, \mathbf{2 t}, \mathbf{2 v}, \mathbf{2 x}$, $\mathbf{2 y}, \mathbf{2 z}, \mathbf{2 e e}$ were synthesized according to reference ${ }^{[1-4]}$, and all analytical data matched the report. Compound $\mathbf{2} \mathbf{w}^{[5]}, 2 \mathbf{d d}^{[6]}$ and $4^{[7,8]}$ was synthesized via known method. BiIM Ligans L1, L2, L3 were synthesized using known method ${ }^{[8]}$.

General Procedure for the Preparation of 2s. ${ }^{[1-4]}$ 


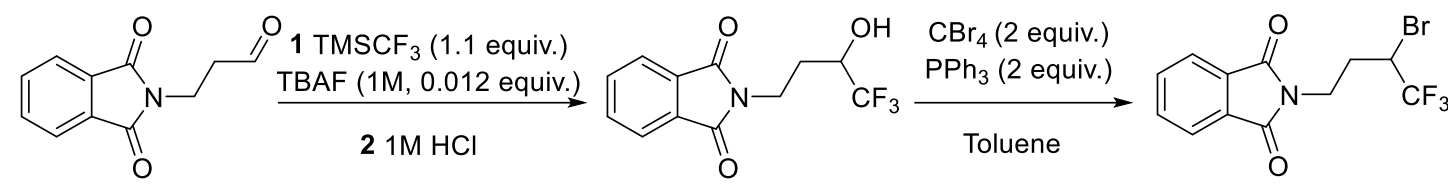

2s

Trifluoromethylation of the aldehyde. A solution of TBAF (1.0 M in THF, 0.12 mmol, 0.012 equiv.) was added over $20 \mathrm{~min}$ to a solution of the 3-(1,3-Dioxoisoindol-2-yl) propanal $(10 \mathrm{mmol})$ and trifluoromethyltrimethylsilane (12 mmol, 1.2 equiv.) in anhydrous THF $(30 \mathrm{~mL})$ at $0{ }^{\circ} \mathrm{C}$ (CAUTION: very exothermic). The resulting mixture was stirred at $0{ }^{\circ} \mathrm{C}$ for $30 \mathrm{~min}$, then was allowed to warm to room temperature. The reaction was stirred for 2 hours. An aqueous solution of $1 \mathrm{~N} \mathrm{HCl}(30 \mathrm{~mL})$ was added, and the mixture was stirred for another 2 hours. Then, the mixture was extracted with ethyl acetate $(3 \times 15 \mathrm{~mL})$, and the combined organic layers were dried over anhydrous $\mathrm{Na}_{2} \mathrm{SO}_{4}$, filtered, and concentrated. The crude product was purified with flash chromatography on silica gel to give trifluoromethylated alcohol.

Bromination of the alcohol. Under the atmosphere of Argon, a solution of trifluoromethylatedalcohol $(8 \mathrm{mmol})$ in toluene $(20 \mathrm{~mL})$ was added to a toluene solution $(5 \mathrm{~mL})$ of triphenylphosphine (16 mmol, 2.0 equiv.). Then, a solution of tetrabromomethane ( $16 \mathrm{mmol}, 2.0$ equiv.) in toluene $(5 \mathrm{~mL})$ was added to the reaction mixture slowly. After stirring for $30 \mathrm{~min}$ at room temperature, the reaction mixture was heated to $110{ }^{\circ} \mathrm{C}$ by oil bath and stirred for 5 hours. The reaction was then cooled to room temperature and filtered. The filtrate was concentrated and the residue was purified with flash chromatography on silica gel.<smiles>O=C1c2ccccc2C(=O)N1CCC(Br)C(F)(F)F</smiles>

$2 s$

${ }^{1} \mathrm{H}$ NMR (600 MHz, Chloroform- $d$ ) $\delta 7.89-7.86(\mathrm{~m}, 2 \mathrm{H}), 7.77$ - $7.74(\mathrm{~m}, 2 \mathrm{H}), 4.19$ $4.10(\mathrm{~m}, 1 \mathrm{H}), 4.01-3.96(\mathrm{~m}, 1 \mathrm{H}), 3.93-3.89(\mathrm{~m}, 1 \mathrm{H}), 2.53-2.48(\mathrm{~m}, 1 \mathrm{H}), 2.28-$ $2.22(\mathrm{~m}, 1 \mathrm{H}) ;{ }^{13} \mathrm{C}$ NMR $(151 \mathrm{MHz}$, Chloroform- $d$ ) $\delta 168.1,134.2,131.8,123.7$ (q, $J$ $=277.8 \mathrm{~Hz}), 123.5,44.3(\mathrm{q}, J=33.2 \mathrm{~Hz}), 35.4,30.8 ;{ }^{19} \mathrm{~F}$ NMR $(565 \mathrm{MHz}$, Chloroform- $d$ ) $\delta-72.4$.

\section{General Procedure for the Preparation of $2 w^{[5]}$}

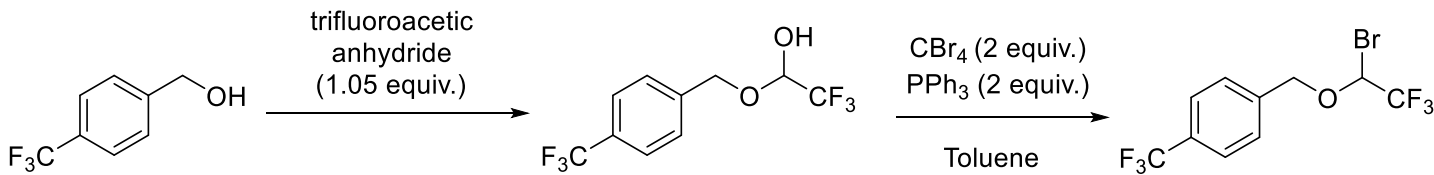


Trifluoromethylation of the 4-(trifluoromethyl)benzyl alcohol. To the solution of $1.76 \mathrm{~g}(10 \mathrm{mmol})$ 4-(trifluoromethyl)benzyl alcohol in $30 \mathrm{ml}$ of dry dichloromethane was slowly added $2.2 \mathrm{~g}$ (1.48 mL, $10.5 \mathrm{mmol}, 1.05$ equiv.) of trifluoroacetic anhydride and stirred for $30 \mathrm{~min}$. After evaporation of solvent, 4-(trifluoromethyl)benzyl trifluoroacetate was obtained as colorless liquid in quantitative yield.

Bromination of the alcohol. Under the atmosphere of Argon, a solution of trifluoromethylatedalcohol $(10 \mathrm{mmol})$ in toluene $(30 \mathrm{~mL})$ was added to a toluene solution $(5 \mathrm{~mL})$ of triphenylphosphine $(20 \mathrm{mmol}, 2.0$ equiv. $)$. Then, a solution of tetrabromomethane ( $20 \mathrm{mmol}, 2.0$ equiv.) in toluene $(5 \mathrm{~mL})$ was added to the reaction mixture slowly. After stirring for $30 \mathrm{~min}$ at room temperature, the reaction mixture was heated to $110{ }^{\circ} \mathrm{C}$ by oil bath and stirred for 5 hours. The reaction was then cooled to room temperature and filtered. The filtrate was concentrated and the residue was purified with flash chromatography on silica gel.<smiles>FC(F)(F)c1ccc(COC(Br)C(F)(F)F)cc1</smiles>

2w

${ }^{1} \mathrm{H}$ NMR (600 MHz, Chloroform- $d$ ) $\delta 7.67(\mathrm{~d}, J=8.0 \mathrm{~Hz}, 2 \mathrm{H}), 7.50(\mathrm{~d}, J=8.1 \mathrm{~Hz}$, $2 \mathrm{H}), 5.83(\mathrm{q}, J=4.7 \mathrm{~Hz}, 1 \mathrm{H}), 5.03(\mathrm{~d}, J=12.2 \mathrm{~Hz}, 1 \mathrm{H}), 4.70(\mathrm{~d}, J=12.2 \mathrm{~Hz}, 1 \mathrm{H}) .{ }^{13} \mathrm{C}$ NMR (151 MHz, Chloroform- $d$ ) $\delta 137.7,131.2(\mathrm{q}, J=11.2 \mathrm{~Hz}), 128.4,125.8(\mathrm{q}, J=$ $3.0 \mathrm{~Hz}), 120.5$ (q, $J=279.4 \mathrm{~Hz}), 80.3(\mathrm{q}, J=39.3 \mathrm{~Hz}), 73.2 ;{ }^{19} \mathrm{~F}$ NMR $(565 \mathrm{MHz}$, Chloroform- $d$ ) $\delta-62.8,-77.5$.

General Procedure for the Preparation of 2dd. ${ }^{[6]}$

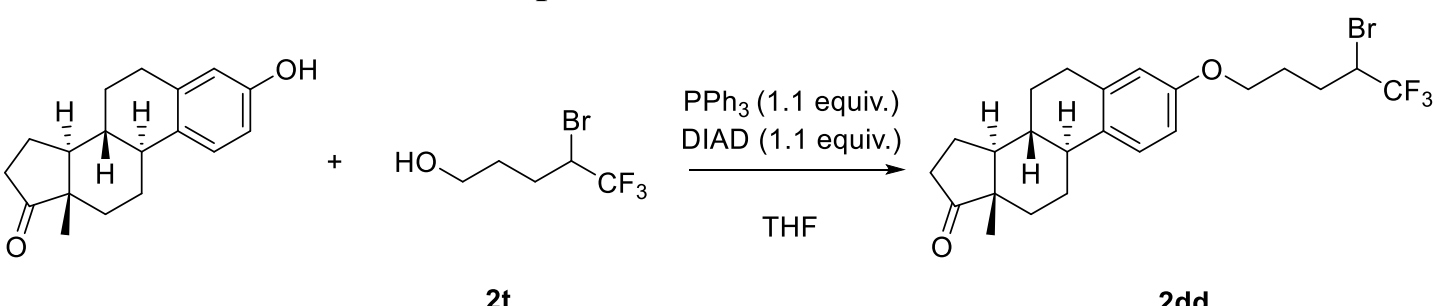

A $25 \mathrm{~mL}$ vial was charged with $\mathbf{2 t}(3 \mathrm{mmol})$, Estrone $(2 \mathrm{mmol})$, THF $(15 \mathrm{~mL})$ and then $\mathrm{PPh}_{3}(2.2 \mathrm{mmol})$ and DIAD $(2.2 \mathrm{mmol})$ were added at room temperature. The mixture was stirred at $\mathrm{rt}$ for $12 \mathrm{~h}$. After completion of the reaction, the mixture was washed with ethyl acetate, and the combined filtrate was concentrated. The residue was purified by flash column chromatography on silica gel. 


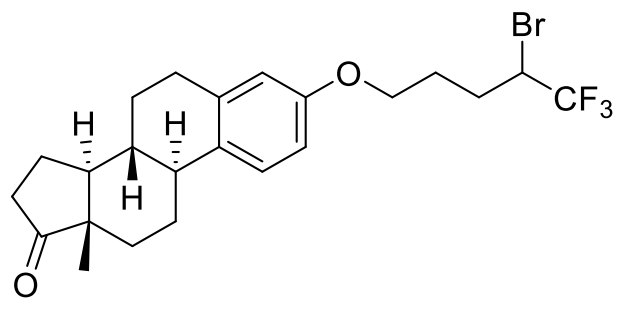

2dd

${ }^{1} \mathrm{H}$ NMR (600 MHz, Chloroform- $d$ ) $\delta 7.23-7.18(\mathrm{~m}, 1 \mathrm{H}), 6.71(\mathrm{dd}, J=8.6,2.7 \mathrm{~Hz}$, $1 \mathrm{H}), 6.64(\mathrm{~d}, J=2.7 \mathrm{~Hz}, 1 \mathrm{H}), 4.22-416(\mathrm{~m}, 1 \mathrm{H}), 4.03-3.94(\mathrm{~m}, 2 \mathrm{H}), 2.91-2.88(\mathrm{~m}$, $2 \mathrm{H}), 2.53-2.48(\mathrm{~m}, 1 \mathrm{H}), 2.41-2.38(\mathrm{~m}, 1 \mathrm{H}), 2.35-2.29(\mathrm{~m}, 1 \mathrm{H}), 2.28-2.23(\mathrm{~m}, 1 \mathrm{H})$, $2.18-2.10(\mathrm{~m}, 2 \mathrm{H}), 2.08-1.98(\mathrm{~m}, 3 \mathrm{H}), 1.96-1.89(\mathrm{~m}, 2 \mathrm{H}), 1.66-1.40(\mathrm{~m}, 6 \mathrm{H})$, $0.91(\mathrm{~s}, 3 \mathrm{H}) ;{ }^{13} \mathrm{C}$ NMR $(151 \mathrm{MHz}$, Chloroform- $d$ ) $\delta 156.6,137.8,132.4,126.4$, $124.0(\mathrm{q}, J=277.8 \mathrm{~Hz}), 114.5,112.0,66.4,50.4,48.0,47.3(\mathrm{q}, J=31.7 \mathrm{~Hz}), 44.0$, 38.3 , 35.9 , 31.6 , 29.6 , 28.5 , 26.7 , 26.5 , 25.9 , 21.6 , 13.8; ${ }^{19} \mathrm{~F}$ NMR (565 MHz, Chloroform- $d$ ) $\delta-72.3$.

\section{General Procedure for the Preparation of 4. ${ }^{[7,8]}$}

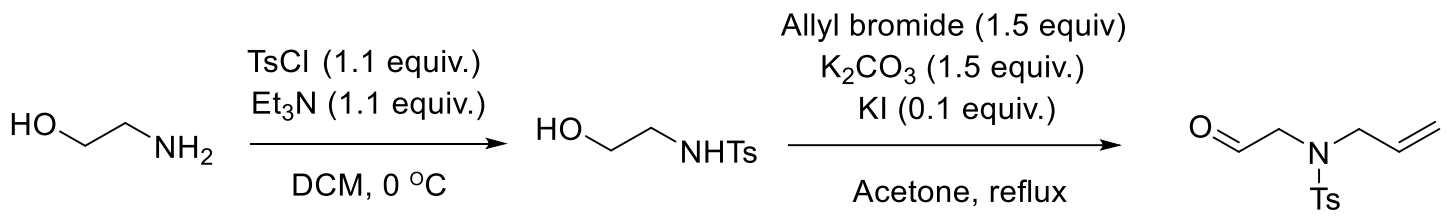

$\mathrm{N}$-(2-Hydroxyethyl)-4-toluenesulfonamide. To a $0^{\circ} \mathrm{C}$ solution of ethanolamine (50 mmol, 1 equiv.) and toluenesulfonyl chloride (55 mmol, 1.1 equiv.) in $\mathrm{CH}_{2} \mathrm{Cl}_{2}$ $(100 \mathrm{~mL}, 0.5 \mathrm{M})$ was added triethylamine $(55 \mathrm{mmol}, 1.1$ equiv.). The reaction mixturewas allowed to warm to ambient temperature and was stirred for 24 hours. The reaction was quenched with $\mathrm{H}_{2} \mathrm{O}$ and the aqueous layer was extracted with $\mathrm{CH}_{2} \mathrm{Cl}_{2}$ (3 $\left.\times 50 \mathrm{~mL}\right)$. The combined organic layers were washed with brine, dried over $\mathrm{MgSO}_{4}$, filtered, and concentrated. The crude product, sulfonamide was carried on without further purification. All physical and spectroscopic data were in accordance with literature data.

2-( $N$-Allyl- $N$-tosylamino) ethanol. To a solution of sulfonamide (50 mmol, 1 equiv.) in acetone (100 mL, $0.5 \mathrm{M})$ was added allyl bromide (75 mmol, 1.5 equiv.), $\mathrm{K}_{2} \mathrm{CO}_{3}$ ( 75 mmol, 1.5 equiv.), and $\mathrm{KI}$ ( $5 \mathrm{mmol}, 0.1$ equiv.). The reaction mixture was heated to reflux by oil bath and stirred for 16 hours. The reaction was quenched with $\mathrm{H}_{2} \mathrm{O}$ and the aqueous layer was extracted with $\mathrm{Et}_{2} \mathrm{O}(3 \times 50 \mathrm{~mL})$. The combined organic layers were washed with brine, dried over $\mathrm{MgSO}_{4}$, filtered, and concentrated. The crude product (41 mmol, $82 \%$ yield) was purified by flash chromatography.

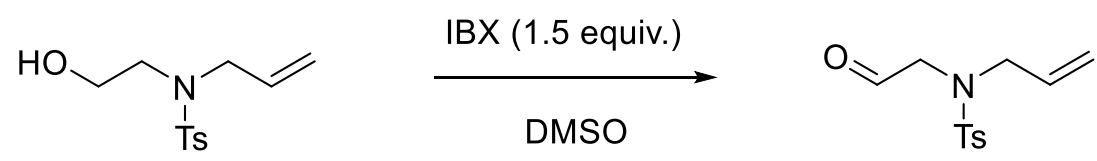

2-( $N$-allyl- $N$-tosylamino) butanal. $(30 \mathrm{mmol})$ of 2 -iodobenzoic acid (IBX) was 
dissolved in dimethyl sulfoxide, DMSO (100 mL), by stirring the mixture for $15 \mathrm{~min}$. To this solution was added ( $20 \mathrm{mmol})$ of 2-(N-Allyl-N-tosylamino) ethanol, After $2 \mathrm{~h}$ of vigorous stirring, the reaction mixture was diluted with water and the precipitate formed was filtered and washed with ethylacetate $(40 \mathrm{~mL})$. The filtrate was then extracted with ethylacetate $(2 \times 40 \mathrm{~mL})$. The combined organic layers were washed with brine, dried over $\mathrm{MgSO}_{4}$, filtered, and concentrated. The brown colored crude aldehyde in quantitative yield was purified by flash chromatography.

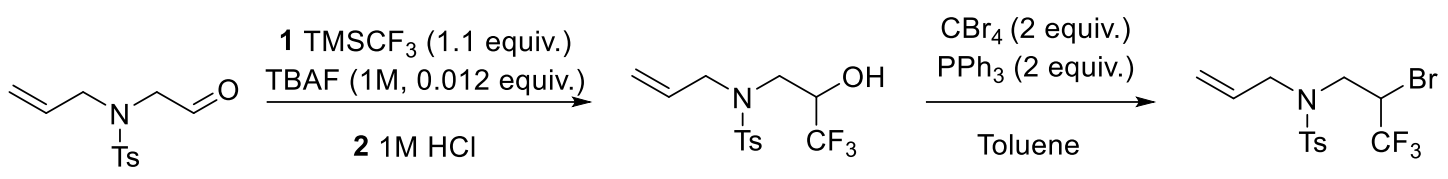

The trifluoromethylation of the aldehyde and bromination of the alcohol step is the same as in procedure for the preparation of $\mathbf{2 s}$.

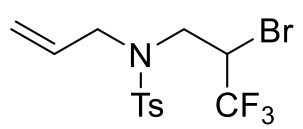

4

${ }^{1} \mathrm{H}$ NMR (600 MHz, $\left.\mathrm{CDCl}_{3}\right) \delta 7.73-7.72(\mathrm{~m}, 2 \mathrm{H}), 7.35(\mathrm{~d}, J=8.0 \mathrm{~Hz}, 2 \mathrm{H}), 5.59-$ $5.52(\mathrm{~m}, 1 \mathrm{H}), 5.21-5.15(\mathrm{~m}, 2 \mathrm{H}), 4.68-4.62(\mathrm{~m}, 1 \mathrm{H}), 3.97-3.93(\mathrm{~m}, 1 \mathrm{H}), 3.87$ $3.83(\mathrm{~m}, 1 \mathrm{H}), 3.68(\mathrm{dd}, J=15.5,4.7 \mathrm{~Hz}, 1 \mathrm{H}), 3.43(\mathrm{dd}, J=15.5,9.1 \mathrm{~Hz}, 1 \mathrm{H}), 2.45$ (s, $3 \mathrm{H}) . ;{ }^{13} \mathrm{C}$ NMR (151 MHz, Chloroform-d) $\delta$ 144.2, 135.4, 131.8, 130.0, 127.4, 123.4 $(\mathrm{q}, J=279.4 \mathrm{~Hz}), 120.6,52.8,48.0(\mathrm{q}, J=3.0 \mathrm{~Hz}), 45.7(\mathrm{q}, J=31.7 \mathrm{~Hz}), 21.6 ;{ }^{19} \mathrm{~F}$ NMR (565 MHz, Chloroform- $d$ ) $\delta-70.7$.

General Procedure for the preparations of BiIM Ligands: ${ }^{[9]}$

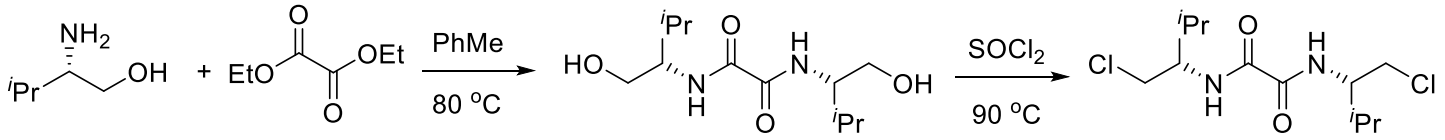

The biimidazole ligands were synthesized according to the previously reported method. $^{[7]}$ (S)-2-amino-3-isopropane-1-ol (2.0 equiv., $\left.20 \mathrm{mmol}, 2.06 \mathrm{~g}\right)$ and dimethyloxalate (1.0 equiv., $10 \mathrm{mmol}, 1.46 \mathrm{~g})$ were dissolved in toluene $(100 \mathrm{~mL})$ and heated to $80{ }^{\circ} \mathrm{C}$ by oil bath. The reaction was allowed to stir overnight with the diamide precipitating out of solution as a white solid. Reaction was cooled to room temperature and concentrated in vacuo to. The crude diol was dissolved in toluene (20 $\mathrm{mL}$ ) and used oil bath heated until $70{ }^{\circ} \mathrm{C}$ whereupon thionyl chloride (2.0 equiv., 20 mmol, $1.6 \mathrm{ml}$ ) was added. Reaction was stirred at $70{ }^{\circ} \mathrm{C}$ for $30 \mathrm{~min}$ then heated to 90 ${ }^{\circ} \mathrm{C}$ for $2 \mathrm{~h}$. The reaction was cooled to room temperature and concentrated under reduced pressure to afford the dichloro-intermediate which was used without further purification. 
<smiles>CCCC(CCl)NC(=O)C(=O)N[C@@H](CC)C(C)C</smiles>

$\mathrm{PhMe}, \mathrm{N}_{2}, 85^{\circ} \mathrm{C}$

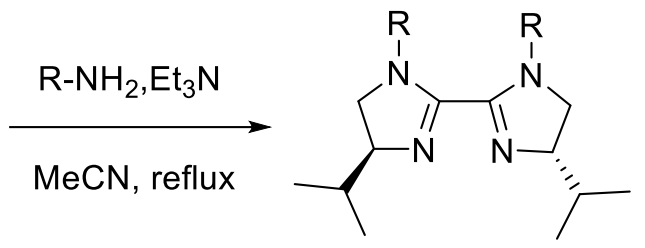

L2

To an overdried three-necked flask was added the crude dichloro-intermediate (1.0 equiv., $5 \mathrm{mmol}$ ) and phosphorus pentachloride (2.4 equiv., $12 \mathrm{mmol}$ ) in $50 \mathrm{~mL}$ of toluene under $\mathrm{N}_{2}$ atmosphere. The reaction was allowed to stir at $85{ }^{\circ} \mathrm{C}$ by oil bath for $4.5 \mathrm{~h}$ before it was cooled to room temperature. Toluene was evaporate under reduced pressure and $\mathrm{Et}_{3} \mathrm{~N}$ (11.2 equiv., $56 \mathrm{mmol}$ ) and isopropylamine (3.0 equiv., $15 \mathrm{mmol}$ ) in $20 \mathrm{~mL}$ of $\mathrm{CH}_{3} \mathrm{CN}$ was added. The reaction was heated to reflux under $\mathrm{N}_{2}$ until TLC showed complete consumption of the starting material. After cooling to room temperature, water was added and the aqueous layer was separated and extracted three times with DCM. The organic layer was dried with $\mathrm{Na}_{2} \mathrm{SO}_{4}$, filtered, and concentrated under reduced pressure. The residue was purified by flash column chromatography to give $\mathbf{L} 2$ as a pale-yellow solid. All the biimidazole ligands $(\mathbf{L 1}, \mathbf{L 2}, \mathbf{L 3})$ in this research were synthesized by following Procedure.

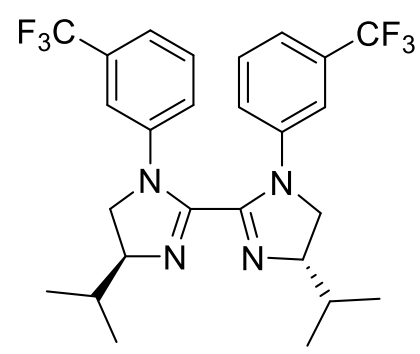

L2

${ }^{1} \mathrm{H}$ NMR (600 MHz, Chloroform- $\left.d\right) \delta 7.13-7.12(\mathrm{~m}, 2 \mathrm{H}), 6.81(\mathrm{~s}, 1 \mathrm{H}), 6.73-6.71(\mathrm{~m}$, $1 \mathrm{H}), 4.07-4.02(\mathrm{~m}, 1 \mathrm{H}), 3.68(\mathrm{t}, J=9.3 \mathrm{~Hz}, 1 \mathrm{H}), 3.58(\mathrm{dd}, J=11.9,9.0 \mathrm{~Hz}, 1 \mathrm{H})$, $2.02-1.97(\mathrm{~m}, 1 \mathrm{H}), 1.17(\mathrm{~d}, J=6.7 \mathrm{~Hz}, 3 \mathrm{H}), 1.03(\mathrm{~d}, J=6.8 \mathrm{~Hz}, 3 \mathrm{H}) ;{ }^{13} \mathrm{C}$ NMR $(151$ $\mathrm{MHz}$, Chloroform- $d$ ) $\delta 152.2,139.9,131.0(\mathrm{q}, J=33.2 \mathrm{~Hz}), 128.9,123.6(\mathrm{q}, J=$ $273.3 \mathrm{~Hz}), 121.4,119.6(\mathrm{q}, J=3.9 \mathrm{~Hz}), 115.1(\mathrm{q}, J=3.9 \mathrm{~Hz}), 71.5$, $53.6,32.8$, $19.7,18.8 ;{ }^{19} \mathrm{~F}$ NMR (565 MHz, Chloroform-d) $\delta-62.5$. 


\section{The characterization of the compounds}

The chiral trifluoromethyl secondary alkyl compounds $\mathbf{3 b} \mathbf{-} \mathbf{3 h}, \mathbf{3 j} \mathbf{\mathbf { j }} \mathbf{3 \mathbf { l }}, \mathbf{3 \mathbf { r }}, \mathbf{3 r}, \mathbf{3 t}$, 3v, 3x - 3z, 3aa and 3bb are known compounds, and all analytical data matched the report $^{[4]} .3 \mathbf{u}$ is also known, and all analytical data matched the report ${ }^{[3]}$.<smiles>N#Cc1ccc([C@H](CCc2ccccc2)C(F)(F)F)cc1</smiles>

$3 \mathbf{a}$

The title compound 3a was synthesized according to General Procedure (SI 4), and it was purified by column chromatography on silica gel (75\% yield, 93:7 er, $43.4 \mathrm{mg}$, colorless oil).

${ }^{1} \mathrm{H}$ NMR (600 MHz, Chloroform-d) $\delta 7.70-7.69(\mathrm{~m}, 2 \mathrm{H}), 7.41(\mathrm{~d}, J=8.1 \mathrm{~Hz}, 2 \mathrm{H})$, $7.30-7.27(\mathrm{~m}, 2 \mathrm{H}), 7.23-7.21(\mathrm{~m}, 1 \mathrm{H}), 7.06-7.05(\mathrm{~m}, 2 \mathrm{H}), 3.32-3.26(\mathrm{~m}, 1 \mathrm{H})$, $2.60-2.56(\mathrm{~m}, 1 \mathrm{H}), 2.42-2.37(\mathrm{~m}, 2 \mathrm{H}), 2.24-2.18(\mathrm{~m}, 1 \mathrm{H}) ;{ }^{13} \mathrm{C}$ NMR $(151 \mathrm{MHz}$, Chloroform- $d$ ) $\delta 139.8,132.6,130.0,128.7,128.3,126.5,126.3$ (q, $J=280.9$ $\mathrm{Hz}), 118.4,112.5,49.2(\mathrm{q}, J=27.2 \mathrm{~Hz}), 42.0,32.3,29.9$ (q, $J=1.5 \mathrm{~Hz}) ;{ }^{19} \mathrm{~F}$ NMR (565 MHz, Chloroform- $d$ ) $\delta$ - 69.3; HRMS (ESI) m/z: $[\mathrm{M}+\mathrm{H}]^{+}$calcd for $\mathrm{C}_{17} \mathrm{H}_{15} \mathrm{~F}_{3} \mathrm{~N}^{+}$: 290.1151; found: 290.1151.; $[\alpha]_{\mathrm{D}}{ }^{19}=-19.845\left(c=1.0, \mathrm{CHCl}_{3}\right)$.

The enantiomeric excess of 3a was determined by chiral HPLC analysis.

Conditions: ChiralPak IA column; hexane $/{ }^{i} \mathrm{PrOH}=98: 2$; flow rate $=1.0 \mathrm{~mL} / \mathrm{min} ; \lambda=$ $220 \mathrm{~nm} ; \mathrm{t}_{\mathrm{R} 1}$ (major) $=8.4 \mathrm{~min} ; \mathrm{t}_{\mathrm{R} 2}$ (minor) $=12.3 \mathrm{~min}$.

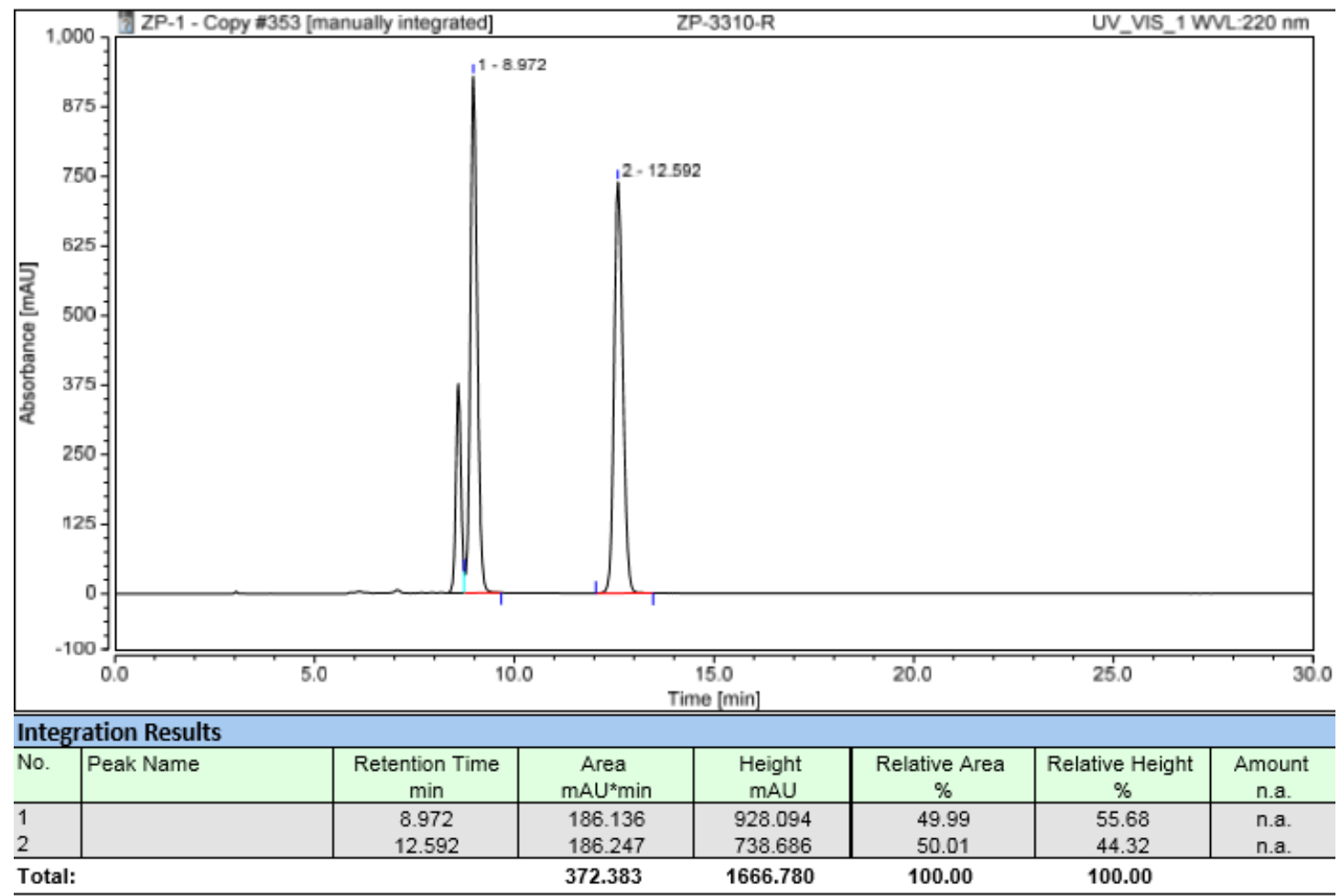




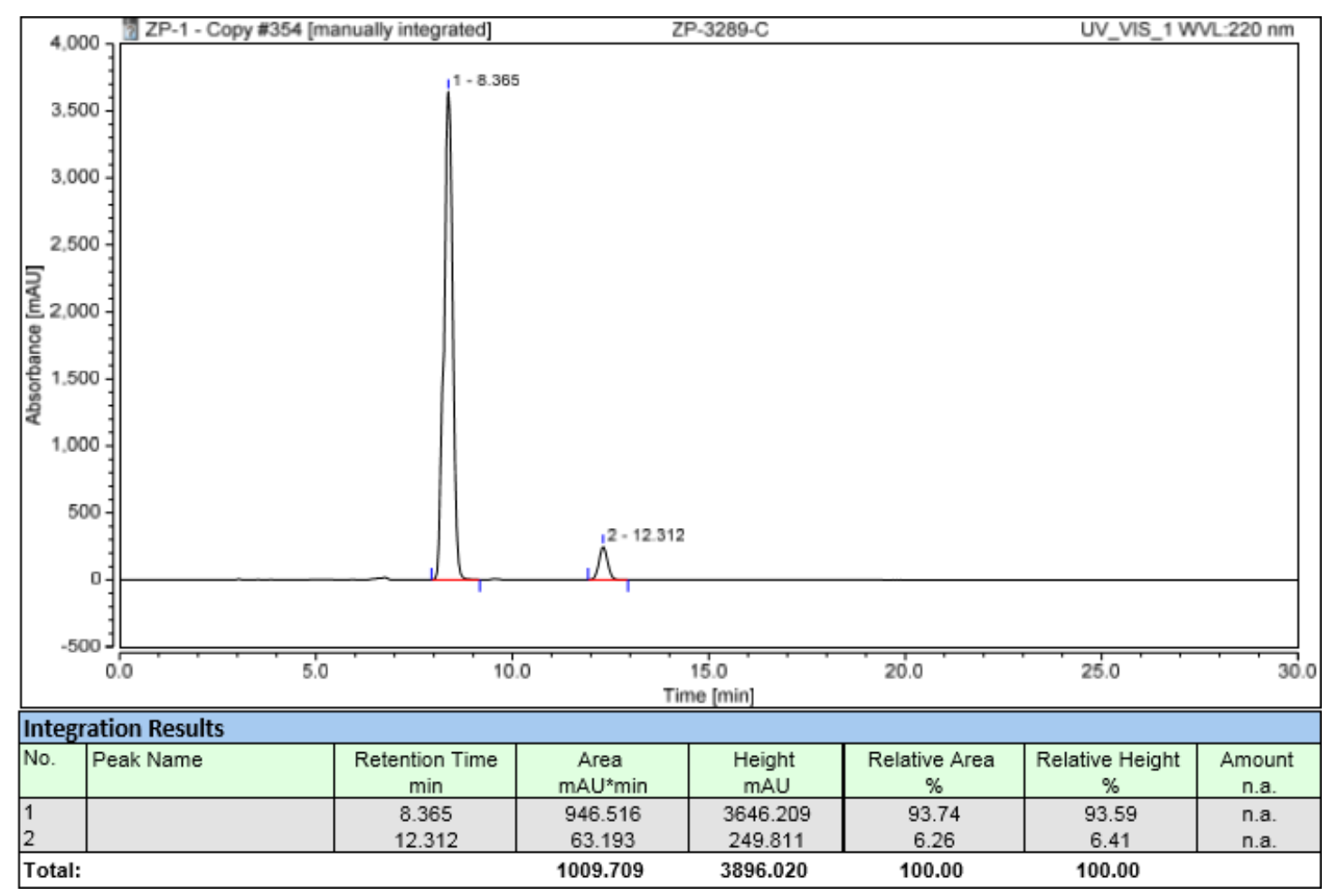<smiles>COC(OC)c1ccc([C@H](CCc2ccccc2)C(F)(F)F)cc1</smiles>

3b

The title compound $\mathbf{3 b}$ was synthesized according to General Procedure (SI 4), and it was purified by column chromatography on silica gel (61\% yield, 92:8 er, $39.0 \mathrm{mg}$, colorless oil).

${ }^{1} \mathrm{H}$ NMR (400 MHz, Chloroform- $d$ ) $\delta 8.07(\mathrm{~d}, J=8.0 \mathrm{~Hz}, 2 \mathrm{H}), 7.38(\mathrm{~d}, J=8.2 \mathrm{~Hz}$, $2 \mathrm{H}), 7.30-7.17(\mathrm{~m}, 3 \mathrm{H}), 7.06(\mathrm{~d}, J=7.4 \mathrm{~Hz}, 2 \mathrm{H}), 3.94(\mathrm{~s}, 3 \mathrm{H}), 3.31-3.24(\mathrm{~m}, 1 \mathrm{H})$, $2.61-2.54(\mathrm{~m}, 1 \mathrm{H}), 2.43-2.33(\mathrm{~m}, 2 \mathrm{H}), 2.28-2.18(\mathrm{~m}, 1 \mathrm{H}) .[\alpha]_{\mathrm{D}}{ }^{19}=-20.570(c=$ $\left.0.5, \mathrm{CHCl}_{3}\right)$.

The enantiomeric excess of $\mathbf{3 b}$ was determined by chiral HPLC analysis.

Conditions: ChiralPak IA column; hexane $/{ }^{i} \mathrm{PrOH}=99: 1$; flow rate $=1.0 \mathrm{~mL} / \mathrm{min} ; \lambda=$ $220 \mathrm{~nm} ; \mathrm{t}_{\mathrm{R} 1}($ major $)=12.1 \mathrm{~min} ; \mathrm{t}_{\mathrm{R} 2}($ minor $)=15.6 \mathrm{~min}$. 

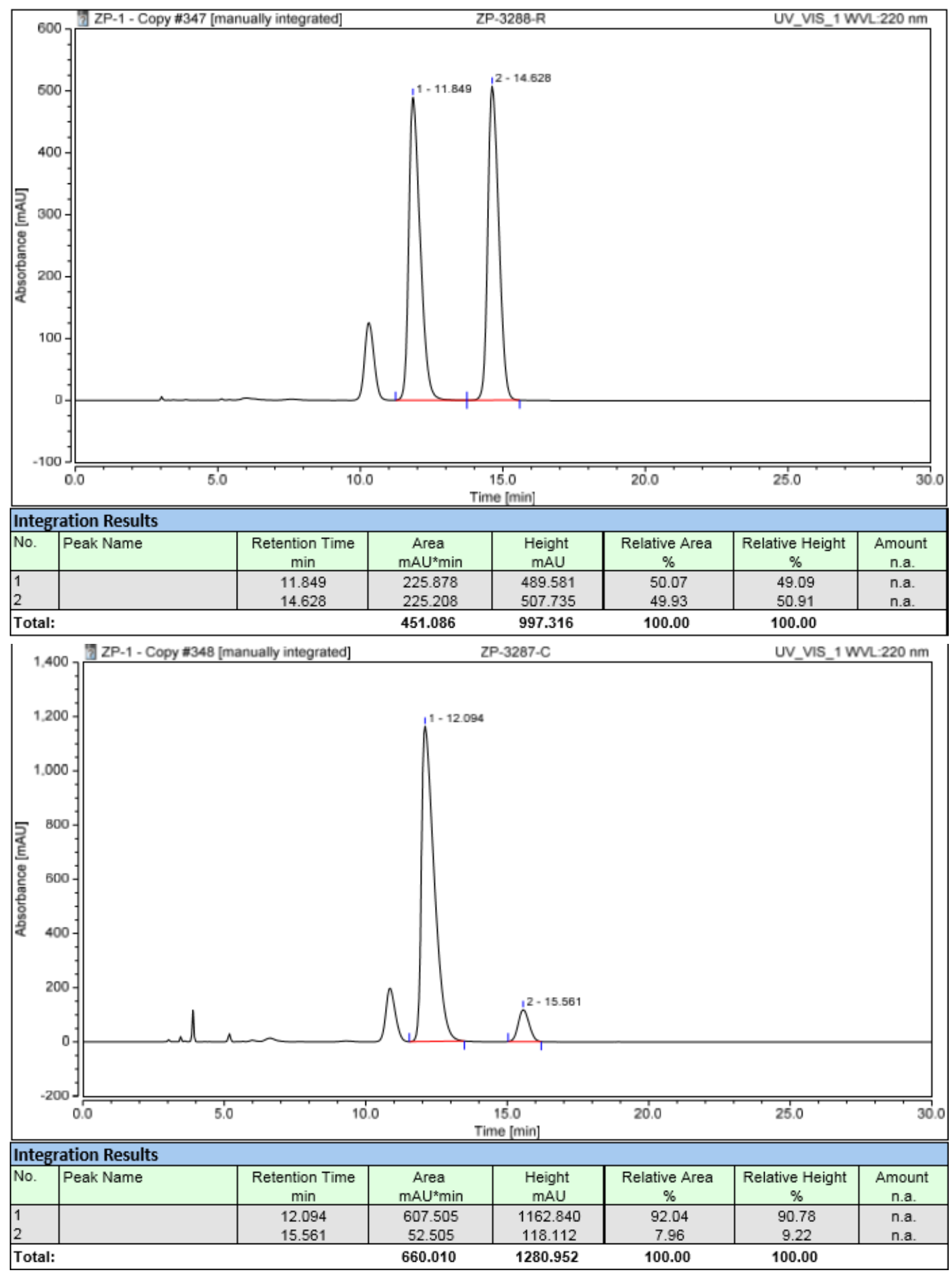<smiles>O=Cc1ccc([C@H](CCc2ccccc2)C(F)(F)F)cc1</smiles> 
The title compound 3c was synthesized according to General Procedure (SI 4), and it was purified by column chromatography on silica gel (71\% yield, 93:7 er, $41.5 \mathrm{mg}$, colorless oil).

${ }^{1} \mathrm{H}$ NMR (400 MHz, Chloroform- $d$ ) $\delta 10.04$ (s, 1H), 7.91 (d, J = 7.8 Hz, 2H), 7.47 (d, $J=7.8 \mathrm{~Hz}, 2 \mathrm{H}), 7.30-7.19(\mathrm{~m}, 3 \mathrm{H}), 7.06(\mathrm{~d}, J=7.3 \mathrm{~Hz}, 2 \mathrm{H}), 3.37-3.27(\mathrm{~m}, 1 \mathrm{H})$, $2.62-2.54(\mathrm{~m}, 1 \mathrm{H}), 2.45-2.35(\mathrm{~m}, 2 \mathrm{H}), 2.30-2.20(\mathrm{~m}) ,1 \mathrm{H}) .[\alpha]_{\mathrm{D}}{ }^{19}=-52.619(c=$ $\left.1.0, \mathrm{CHCl}_{3}\right)$.

The enantiomeric excess of $\mathbf{3 c}$ was determined by chiral HPLC analysis.

Conditions: ChiralPak IB column; hexane $/{ }^{i} \mathrm{PrOH}=99: 1$; flow rate $=1.0 \mathrm{~mL} / \mathrm{min} ; \lambda=$ $254 \mathrm{~nm} ; \mathrm{t}_{\mathrm{R} 1}($ major $)=21.6 \mathrm{~min} ; \mathrm{t}_{\mathrm{R} 2}($ minor $)=24.4 \mathrm{~min}$.

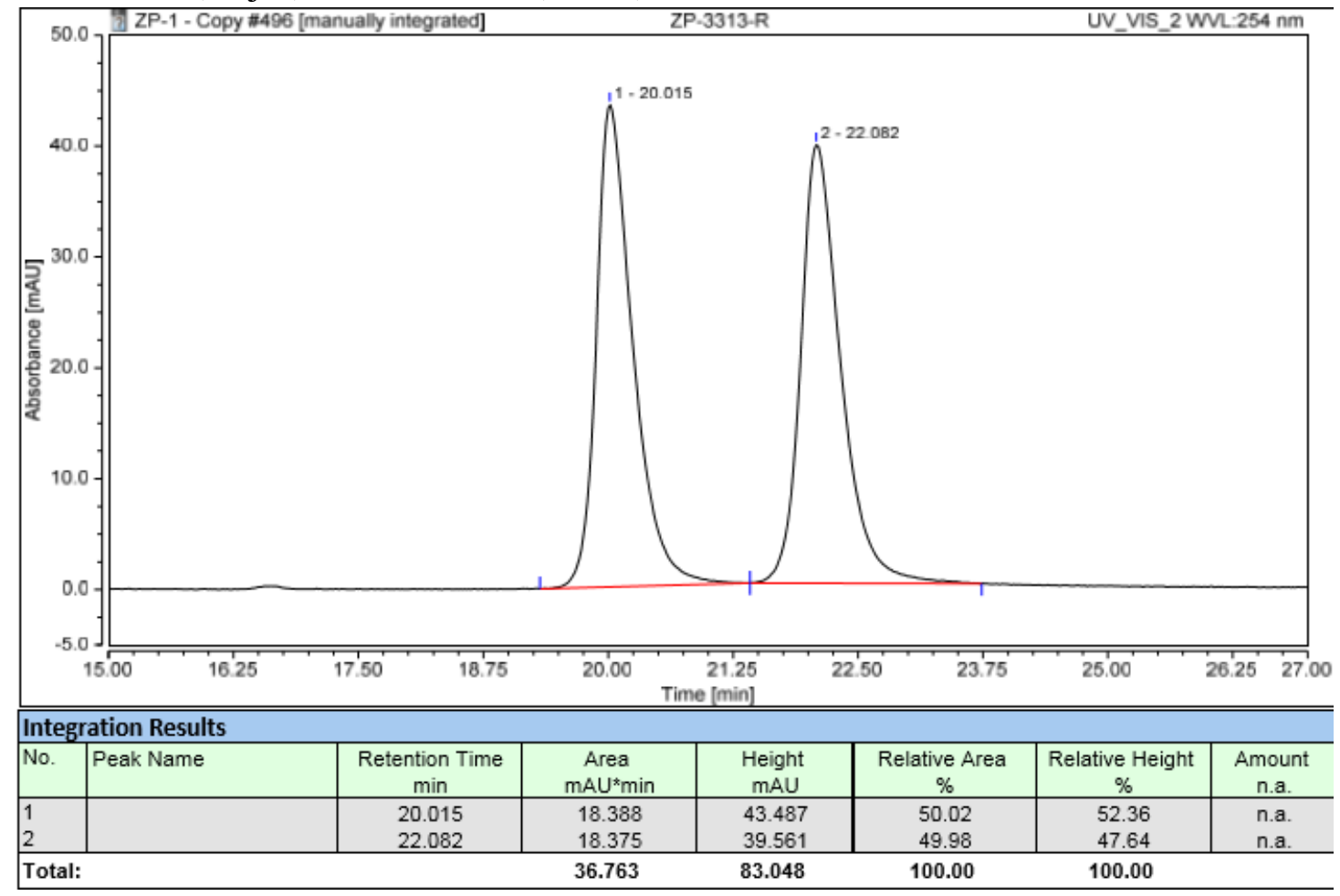




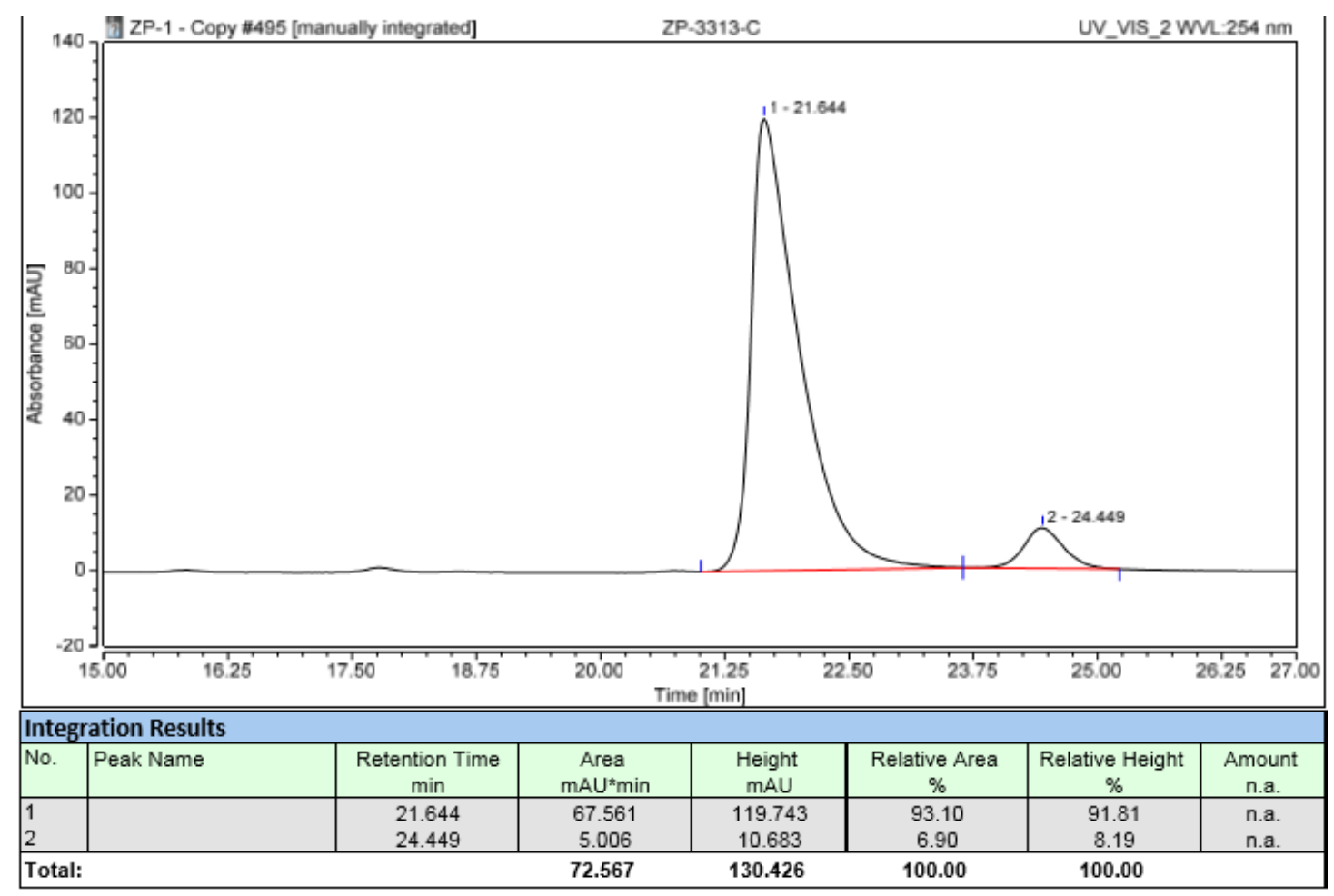<smiles>CC(=O)c1ccc(C(CCc2ccccc2)C(F)(F)F)cc1</smiles>

$3 d$

The title compound 3d was synthesized according to General Procedure (SI 4), and it was purified by column chromatography on silica gel (64\% yield, 92:8 er, $39.4 \mathrm{mg}$, colorless oil).

${ }^{1} \mathrm{H}$ NMR (400 MHz, Chloroform- $d$ ) $\delta 7.99(\mathrm{~d}, J=8.0 \mathrm{~Hz}, 2 \mathrm{H}), 7.40(\mathrm{~d}, J=7.9 \mathrm{~Hz}$, $2 \mathrm{H}), 7.28(\mathrm{q}, J=5.5,3.7 \mathrm{~Hz}, 2 \mathrm{H}), 7.21(\mathrm{t}, J=7.3 \mathrm{~Hz}, 1 \mathrm{H}), 7.07(\mathrm{~d}, J=7.3 \mathrm{~Hz}, 2 \mathrm{H})$, $3.33-3.27(\mathrm{~m}, 1 \mathrm{H}), 2.63(\mathrm{~s}, 3 \mathrm{H}), 2.59-2.54(\mathrm{~m}, 1 \mathrm{H}), 2.44-2.34(\mathrm{~m}, 2 \mathrm{H}), 2.29-2.19$ $(\mathrm{m}, 1 \mathrm{H}) .[\alpha]_{\mathrm{D}}{ }^{19}=-52.619\left(c=1.0, \mathrm{CHCl}_{3}\right)$.

The enantiomeric excess of $\mathbf{3 d}$ was determined by chiral HPLC analysis.

Conditions: ChiralPak OJ-H column; hexane $/{ }^{i} \mathrm{PrOH}=85: 15$; flow rate $=1.0 \mathrm{~mL} / \mathrm{min}$; $\lambda=220 \mathrm{~nm} ; \mathrm{t}_{\mathrm{R} 1}$ (major) $=10.2 \mathrm{~min} ; \mathrm{t}_{\mathrm{R} 2}$ (minor) $=9.0 \mathrm{~min}$. 


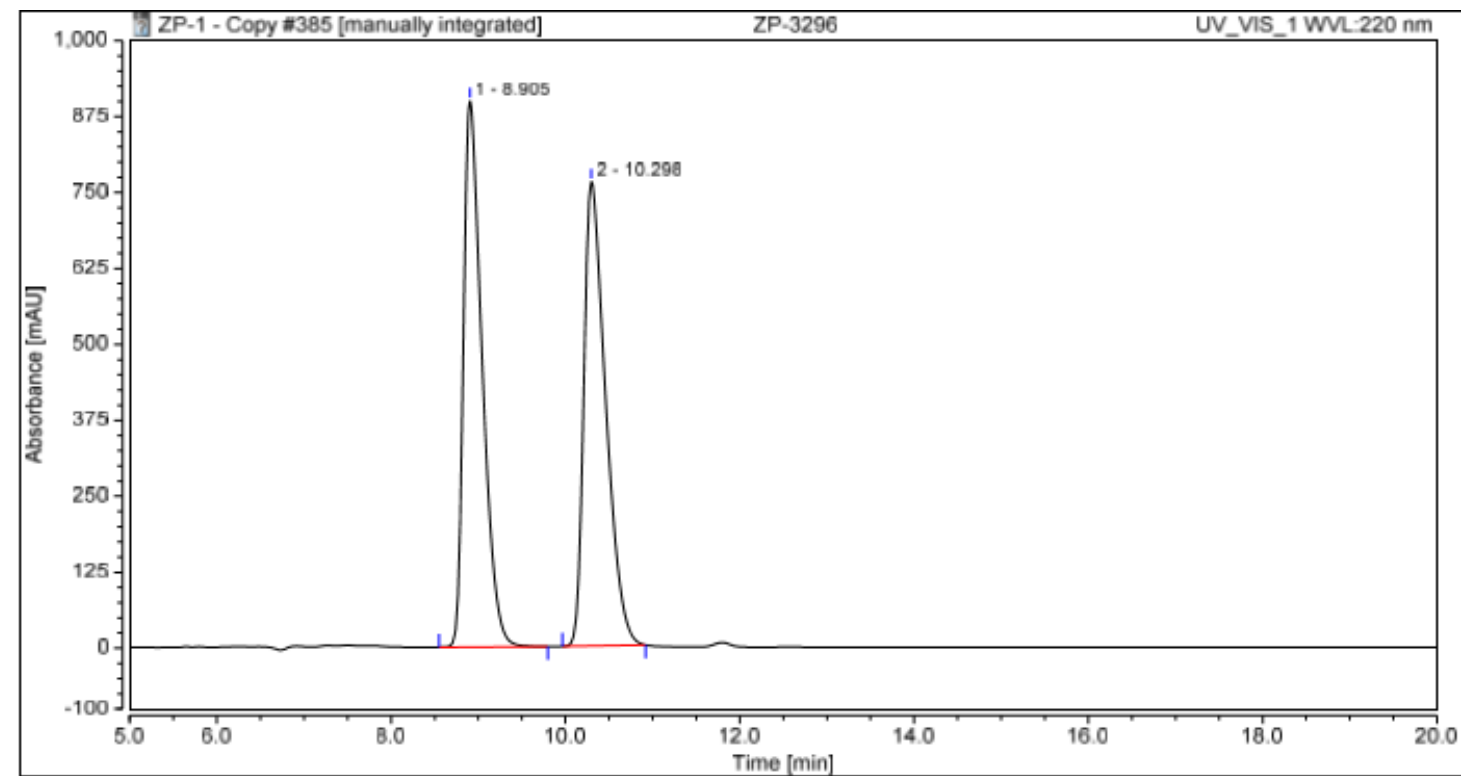

\begin{tabular}{l|l|c|c|c|c|c|c}
\hline \hline Integration Results \\
\hline No. & Peak Name & $\begin{array}{c}\text { Retention Time } \\
\text { min }\end{array}$ & $\begin{array}{c}\text { Area } \\
\text { mAU*min }\end{array}$ & $\begin{array}{c}\text { Height } \\
\text { mAU }\end{array}$ & $\begin{array}{c}\text { Relative Area } \\
\%\end{array}$ & $\begin{array}{c}\text { Relative Height } \\
\%\end{array}$ & $\begin{array}{c}\text { Amount } \\
\text { n.a. }\end{array}$ \\
\hline 1 & & 8.905 & 221.738 & 898.540 & 50.12 & 54.05 & n.a. \\
2 & & 10.298 & 220.641 & 763.733 & 49.88 & 45.95 & n.a. \\
\hline
\end{tabular}

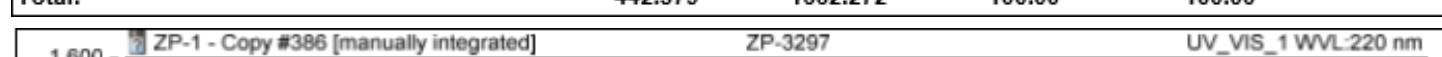

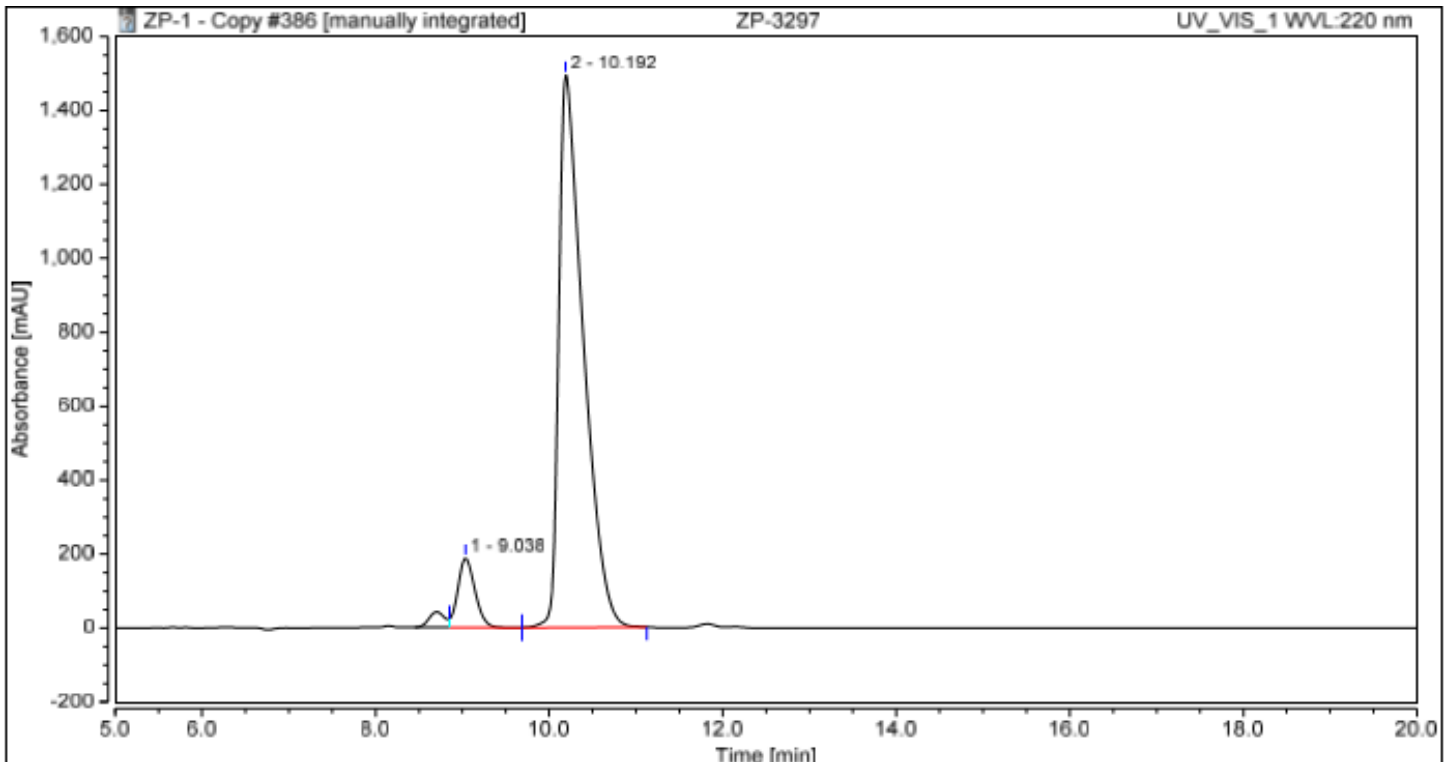

\begin{tabular}{|c|c|c|c|c|c|c|c|}
\hline \multicolumn{8}{|c|}{ Integration Results } \\
\hline No. & Peak Name & $\begin{array}{l}\text { Retention Time } \\
\text { min }\end{array}$ & $\begin{array}{c}\text { Area } \\
\mathrm{mAU}^{*} \mathrm{~min}\end{array}$ & $\begin{array}{c}\text { Height } \\
\text { mAU }\end{array}$ & $\begin{array}{c}\text { Relative Area } \\
\%\end{array}$ & $\begin{array}{c}\text { Relative Height } \\
\%\end{array}$ & $\begin{array}{c}\text { Amount } \\
\text { n.a. }\end{array}$ \\
\hline \begin{tabular}{|l}
1 \\
2 \\
\end{tabular} & & $\begin{array}{c}9.038 \\
10.192 \\
\end{array}$ & $\begin{array}{c}42.773 \\
487.599 \\
\end{array}$ & $\begin{array}{c}188.217 \\
1494.220 \\
\end{array}$ & $\begin{array}{c}8.06 \\
91.94 \\
\end{array}$ & $\begin{array}{r}11.19 \\
88.81 \\
\end{array}$ & $\begin{array}{l}\text { n.a. } \\
\text { n.a. }\end{array}$ \\
\hline \multicolumn{3}{|c|}{ Total: } & 530.373 & 1682.437 & 100.00 & 100.00 & \\
\hline
\end{tabular}<smiles>O=C(c1ccccc1)c1ccc([C@H](CCc2ccccc2)C(F)(F)F)cc1</smiles> 
The title compound 3e was synthesized according to General Procedure (SI 4), and it was purified by column chromatography on silica gel (66\% yield, 92:8 er, $48.5 \mathrm{mg}$, colorless oil).

${ }^{1} \mathrm{H}$ NMR (400 MHz, Chloroform- $d$ ) $\delta 7.84(\mathrm{dd}, J=7.8,3.4 \mathrm{~Hz}, 4 \mathrm{H}), 7.61(\mathrm{t}, J=7.3$ $\mathrm{Hz}, 1 \mathrm{H}), 7.51(\mathrm{t}, J=7.5 \mathrm{~Hz}, 2 \mathrm{H}), 7.42(\mathrm{~d}, J=7.9 \mathrm{~Hz}, 2 \mathrm{H}), 7.28(\mathrm{q}, J=7.5 \mathrm{~Hz}, 2 \mathrm{H})$, $7.21(\mathrm{t}, J=7.3 \mathrm{~Hz}, 1 \mathrm{H}), 7.09(\mathrm{~d}, J=7.4 \mathrm{~Hz}, 2 \mathrm{H}), 3.38-3.27(\mathrm{~m}, 1 \mathrm{H}), 2.65-2.58(\mathrm{~m}$, $1 \mathrm{H}), 2.48-2.35(\mathrm{~m}, 2 \mathrm{H}), 2.31-2.21(\mathrm{~m}, 1 \mathrm{H}) .[\alpha]_{\mathrm{D}}{ }^{19}=-38.445\left(c=1.0, \mathrm{CHCl}_{3}\right)$.

The enantiomeric excess of $\mathbf{3 e}$ was determined by chiral HPLC analysis.

Conditions: ChiralPak OJ-H column; hexane $/{ }^{i} \mathrm{PrOH}=85: 15$; flow rate $=1.0 \mathrm{~mL} / \mathrm{min}$; $\lambda=220 \mathrm{~nm} ; \mathrm{t}_{\mathrm{R} 1}$ (major) $=13.1 \mathrm{~min} ; \mathrm{t}_{\mathrm{R} 2}($ minor $)=11.2 \mathrm{~min}$.

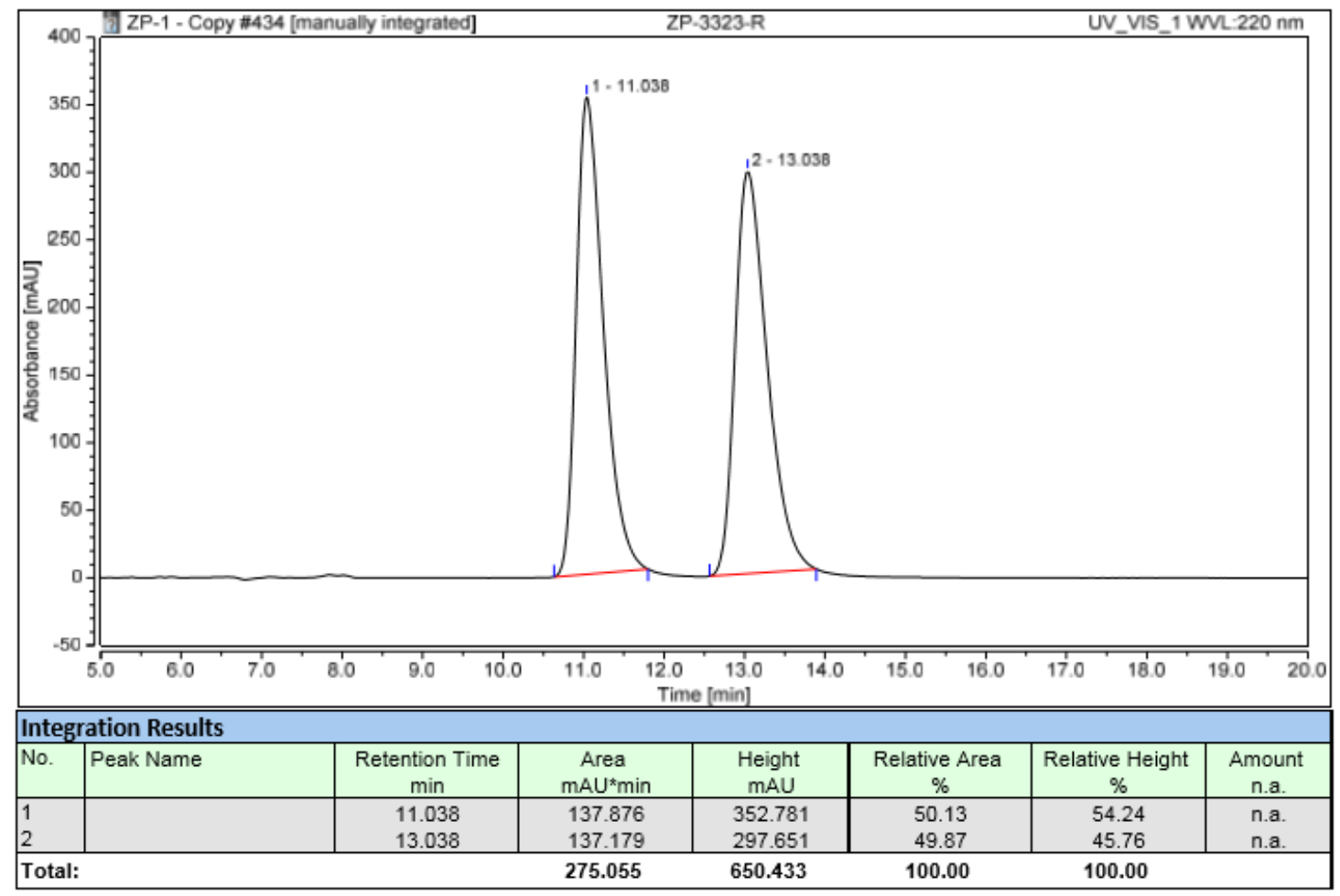




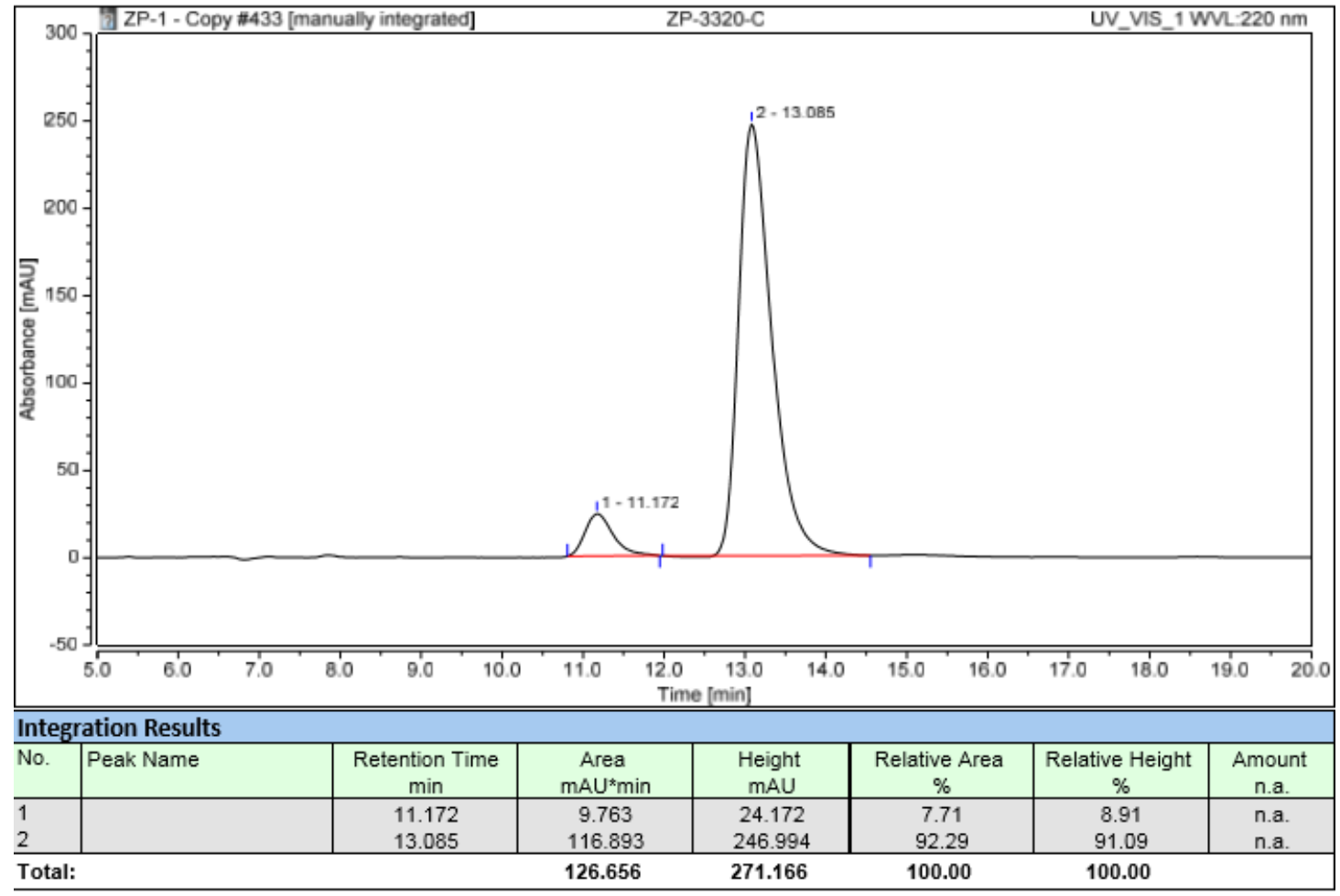<smiles>CSc1ccc([C@H](CCc2ccccc2)C(F)(F)F)cc1</smiles>

3f

The title compound $\mathbf{3 f}$ was synthesized according to General Procedure (SI 4), and it was purified by column chromatography on silica gel (74\% yield, 91:9 er, $46.0 \mathrm{mg}$, colorless oil).

${ }^{1} \mathrm{H}$ NMR (600 MHz, Chloroform-d) $\delta 7.29$ - 7.26 (m, 4H), 7.22 - 7.19 (m, 3H), 7.09 $7.07(\mathrm{~m}, 2 \mathrm{H}), 3.20-3.14(\mathrm{~m}, 1 \mathrm{H}), 2.62-2.56(\mathrm{~m}, 1 \mathrm{H}), 2.51$ (s, 3H), $2.40(\mathrm{dt}, J=13.8$, $8.4 \mathrm{~Hz}, 1 \mathrm{H}), 2.35-2.29(\mathrm{~m}, 1 \mathrm{H}), 2.21-2.15(\mathrm{~m}, 1 \mathrm{H}) .[\alpha]_{\mathrm{D}}{ }^{19}=-62.347(c=0.5$, $\left.\mathrm{CHCl}_{3}\right)$.

The enantiomeric excess of $\mathbf{3 f}$ was determined by chiral HPLC analysis.

Conditions: ChiralPak OJ-H column; hexane $/{ }^{i} \mathrm{PrOH}=85: 5$; flow rate $=1.0 \mathrm{~mL} / \mathrm{min}$; $\lambda=254 \mathrm{~nm} ; \mathrm{t}_{\mathrm{R} 1}$ (major) $=7.6 \mathrm{~min} ; \mathrm{t}_{\mathrm{R} 2}($ minor $)=8.3 \mathrm{~min}$. 

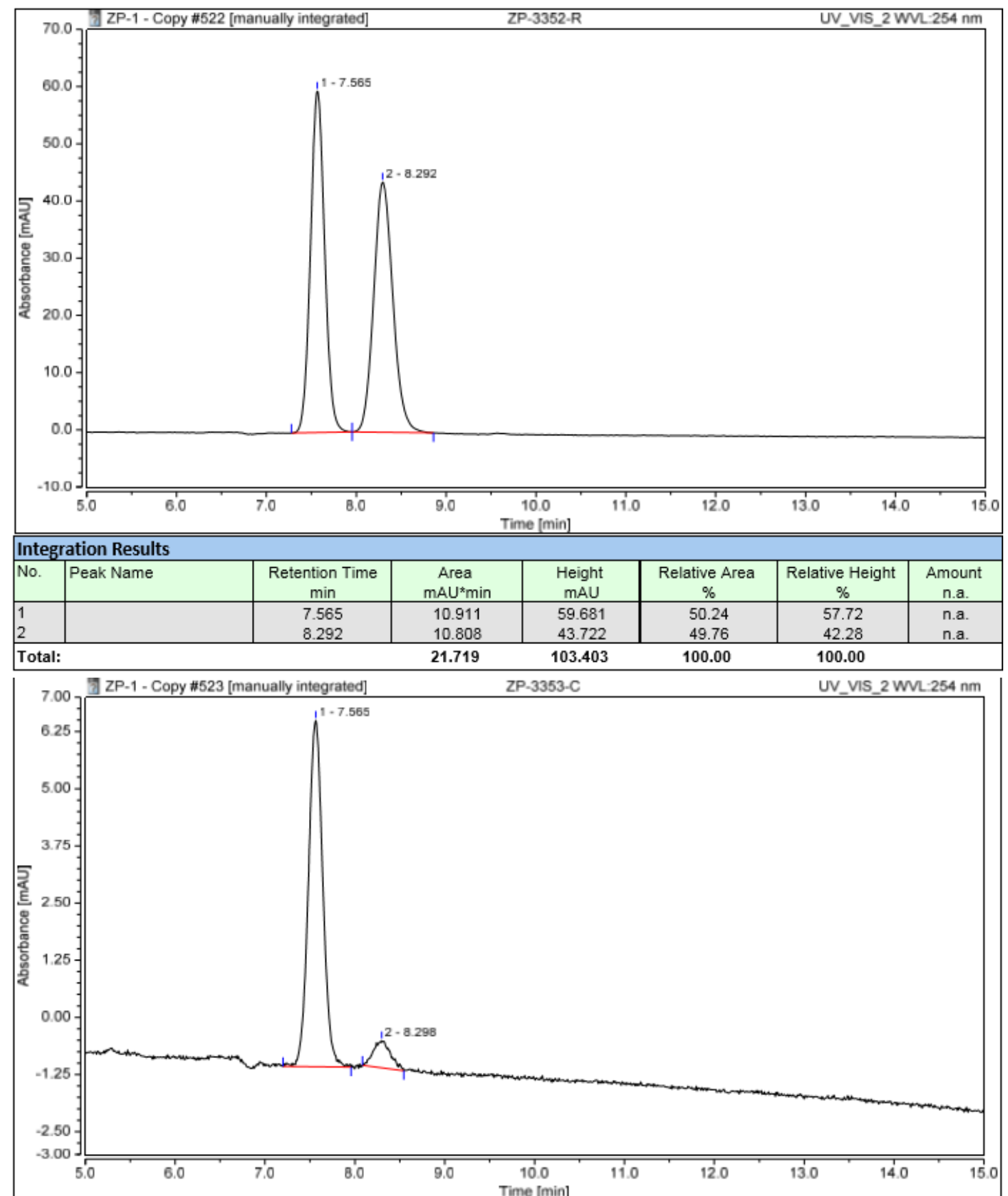

\begin{tabular}{|l|l|c|c|c|c|c|c|}
\hline \multicolumn{1}{|l|}{ Integration Results } \\
\hline No. & Peak Name & $\begin{array}{c}\text { Retention Time } \\
\text { min }\end{array}$ & $\begin{array}{c}\text { Area } \\
\text { mAU*min }\end{array}$ & $\begin{array}{c}\text { Height } \\
\text { mAU }\end{array}$ & $\begin{array}{c}\text { Relative Area } \\
\%\end{array}$ & $\begin{array}{c}\text { Relative Height } \\
\%\end{array}$ & $\begin{array}{c}\text { Amount } \\
\text { n.a. }\end{array}$ \\
\hline 1 & & 7.565 & 1.411 & 7.575 & 91.41 & 92.72 & n.a. \\
2 & 8.298 & 0.133 & 0.595 & 8.59 & n.a. \\
\hline
\end{tabular}<smiles>CS(=O)(=O)c1ccc([C@H](CCc2ccccc2)C(F)(F)F)cc1</smiles>

$3 g$ 
The title compound $\mathbf{3 g}$ was synthesized according to General Procedure (SI 4), and it was purified by column chromatography on silica gel (79\% yield, 92.5:7.5 er, 54.4 mg, colorless oil).

${ }^{1} \mathrm{H}$ NMR (400 MHz, Chloroform- $d$ ) $\delta 7.98(\mathrm{~d}, J=8.0 \mathrm{~Hz}, 2 \mathrm{H}), 7.50(\mathrm{~d}, J=8.0 \mathrm{~Hz}$, 2H), 7.29 (t, $J=7.2 \mathrm{~Hz}, 2 \mathrm{H}), 7.22(\mathrm{t}, J=7.3 \mathrm{~Hz}, 1 \mathrm{H}), 7.06(\mathrm{~d}, J=7.3 \mathrm{~Hz}, 2 \mathrm{H}), 3.38$ $3.29(\mathrm{~m}, 1 \mathrm{H}), 3.10(\mathrm{~s}, 3 \mathrm{H}), 2.56-2.24(\mathrm{~m}, 1 \mathrm{H}), 2.46-2.37(\mathrm{~m}, 2 \mathrm{H}), 2.28-2.20(\mathrm{~m}$, $1 \mathrm{H}) .[\alpha]_{\mathrm{D}}{ }^{19}=-19.386\left(c=0.5, \mathrm{CHCl}_{3}\right)$.

The enantiomeric excess of $\mathbf{3 f}$ was determined by chiral HPLC analysis.

Conditions: ChiralPak IA column; hexane $/{ }^{i} \mathrm{PrOH}=90: 10$; flow rate $=1.0 \mathrm{~mL} / \mathrm{min} ; \lambda=$ $220 \mathrm{~nm} ; \mathrm{t}_{\mathrm{R} 1}$ (major) $=10.4 \mathrm{~min} ; \mathrm{t}_{\mathrm{R} 2}($ minor $)=14.3 \mathrm{~min}$.

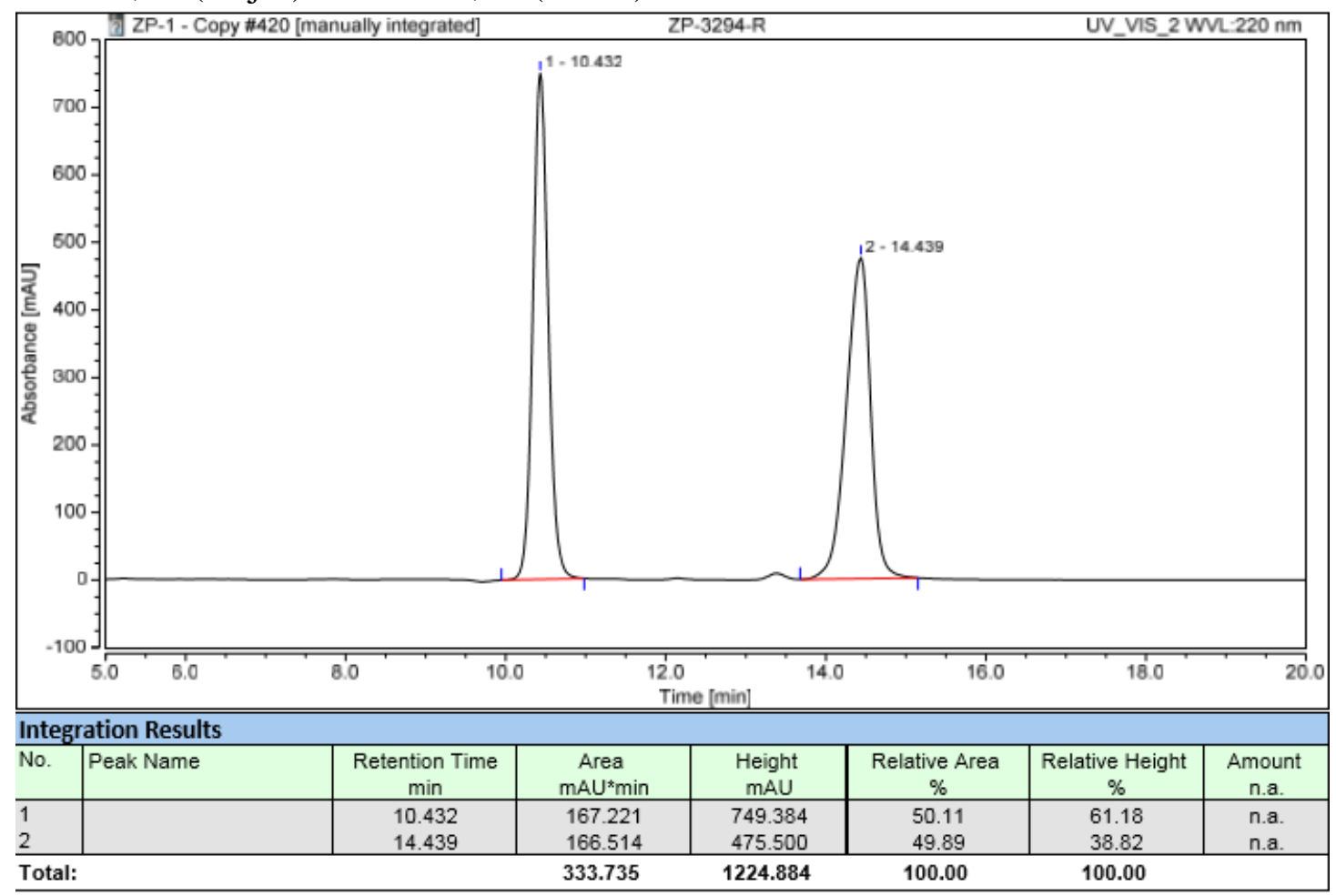




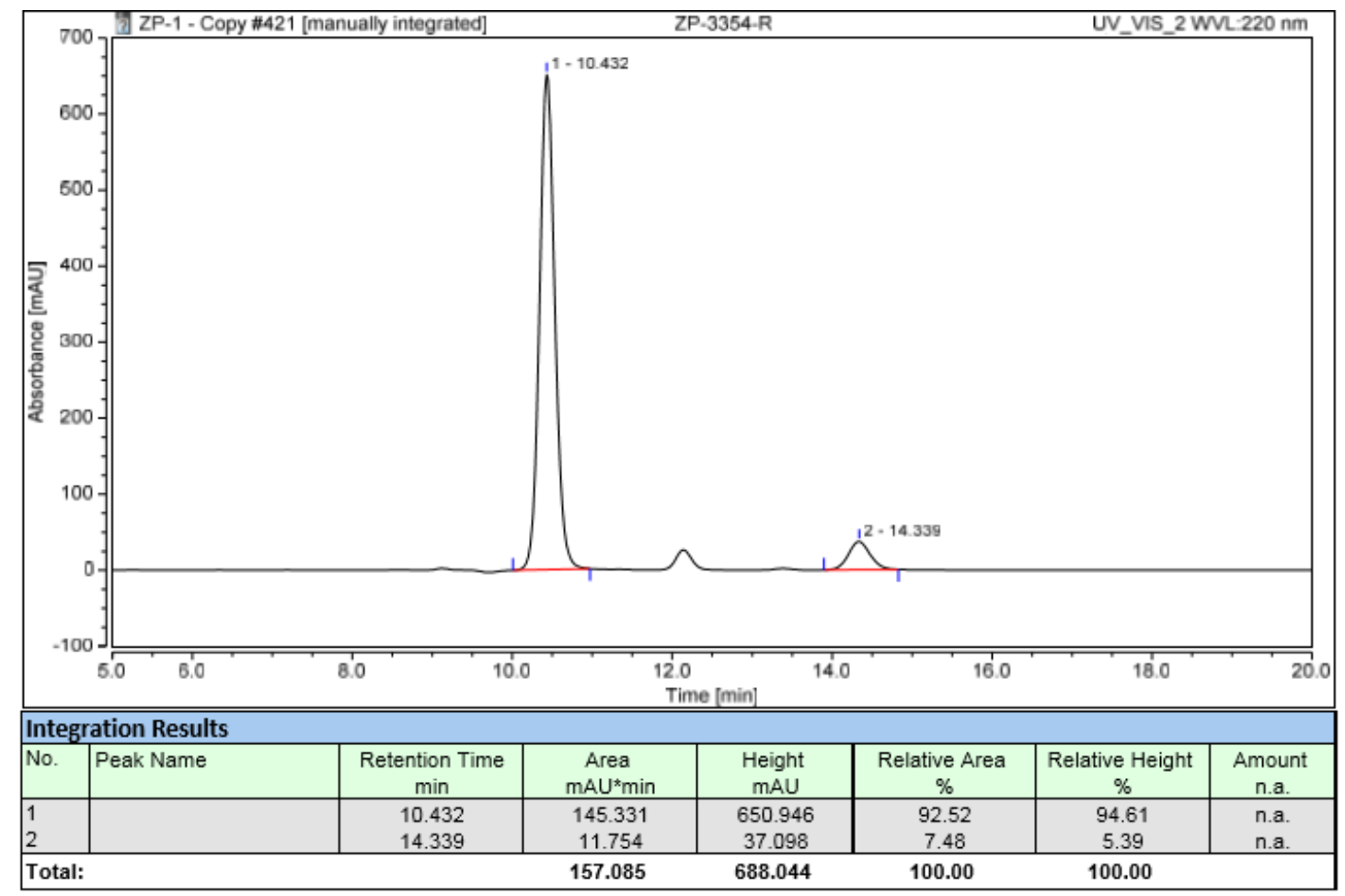<smiles>COc1ccc([C@H](CCc2ccccc2)C(F)(F)F)cc1</smiles>

$3 h$

The title compound $\mathbf{3 h}$ was synthesized according to General Procedure (SI 4), and it was purified by column chromatography on silica gel (72\% yield, 88:12 er, $42.5 \mathrm{mg}$, colorless oil).

${ }^{1} \mathrm{H}$ NMR (400 MHz, Chloroform- $d$ ) $\delta 7.30-7.20(\mathrm{~m}, 5 \mathrm{H}), 7.09(\mathrm{~d}, J=7.4 \mathrm{~Hz}, 2 \mathrm{H})$, $6.92(\mathrm{~d}, J=8.6 \mathrm{~Hz}, 2 \mathrm{H}), 3.83(\mathrm{~s}, 3 \mathrm{H}), 3.20-3.11(\mathrm{~m}, 1 \mathrm{H}), 2.62-2.55(\mathrm{~m}, 1 \mathrm{H}), 2.44$ $2.27(\mathrm{~m}, 2 \mathrm{H}), 2.22-2.12(\mathrm{~m}, 1 \mathrm{H}) .[\alpha]_{\mathrm{D}}{ }^{19}=-22.673\left(c=1.0, \mathrm{CHCl}_{3}\right)$.

The enantiomeric excess of $\mathbf{3 f}$ was determined by chiral HPLC analysis.

Conditions: ChiralPak OJ-H column; hexane $/{ }^{i} \mathrm{PrOH}=85: 15$; flow rate $=1.0 \mathrm{~mL} / \mathrm{min}$; $\lambda=220 \mathrm{~nm} ; \mathrm{t}_{\mathrm{R} 1}$ (major) $=7.3 \mathrm{~min} ; \mathrm{t}_{2}($ minor $)=9.9 \mathrm{~min}$. 

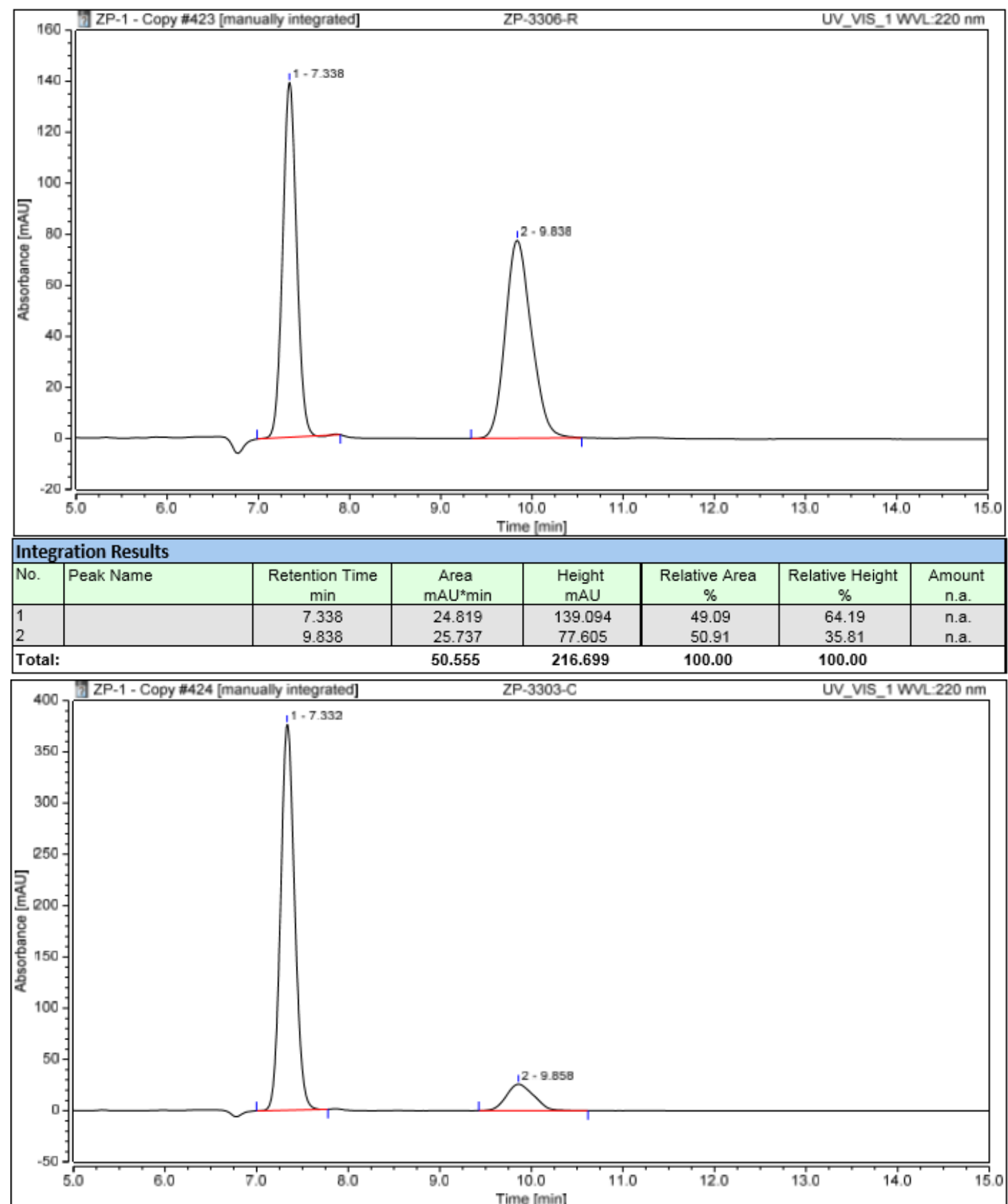

\begin{tabular}{|c|c|c|c|c|c|c|c|}
\hline \multicolumn{8}{|c|}{ Integration Results } \\
\hline No. & Peak Name & $\begin{array}{c}\text { Retention Time } \\
\text { min }\end{array}$ & $\begin{array}{c}\text { Area } \\
\mathrm{mAU}{ }^{*} \mathrm{~min}\end{array}$ & $\begin{array}{c}\text { Height } \\
\text { mAU }\end{array}$ & $\begin{array}{c}\text { Relative Area } \\
\% \\
\end{array}$ & \begin{tabular}{|c|} 
Relative Height \\
$\%$ \\
\end{tabular} & $\begin{array}{c}\text { Amount } \\
\text { n.a. }\end{array}$ \\
\hline $\begin{array}{l}1 \\
2 \\
\end{array}$ & & $\begin{array}{l}7.332 \\
9.858\end{array}$ & $\begin{array}{c}67.103 \\
9.044\end{array}$ & $\begin{array}{c}376.187 \\
25.830 \\
\end{array}$ & $\begin{array}{l}88.12 \\
11.88 \\
\end{array}$ & $\begin{array}{c}93.57 \\
6.43 \\
\end{array}$ & $\begin{array}{l}\text { n.a. } \\
\text { n.a. }\end{array}$ \\
\hline \multicolumn{3}{|c|}{ Total: } & 76.148 & 402.017 & 100.00 & 100.00 & \\
\hline
\end{tabular}<smiles>N#Cc1cccc([C@H](CCc2ccccc2)C(F)(F)F)c1</smiles> 
The title compound 3i was synthesized according to General Procedure (SI 4), and it was purified by column chromatography on silica gel (60\% yield, 91:9 er, $35.0 \mathrm{mg}$, colorless oil).

${ }^{1} \mathrm{H}$ NMR (400 MHz, Chloroform- $d$ ) $\delta 7.68$ - $7.66(\mathrm{~m}, 1 \mathrm{H}), 7.57$ - 7.49 (m, 3H), 7.31 $7.20(\mathrm{~m}, 3 \mathrm{H}), 7.06(\mathrm{~d}, J=7.3 \mathrm{~Hz}, 2 \mathrm{H}), 3.31-3.21(\mathrm{~m}, 1 \mathrm{H}), 2.63-2.56(\mathrm{~m}, 1 \mathrm{H}), 2.44-$ $2.35(\mathrm{~m}, 2 \mathrm{H}), 2.26-2.16(\mathrm{~m}, 1 \mathrm{H}) .{ }^{13} \mathrm{C} \mathrm{NMR}(101 \mathrm{MHz}$, Chloroform- $d) \delta 139.7$, $136.1,133.6,132.7,132.0,129.7,128.7,128.3,126.5,126.3(\mathrm{q}, J=280.8$ $\mathrm{Hz}), 118.3,113.2,48.9$ (q, $J=27.3 \mathrm{~Hz}),, 32.3,29.8(\mathrm{q}, J=2.0 \mathrm{~Hz}) .{ }^{19} \mathrm{~F}$ NMR $(376$ $\mathrm{MHz}$, Chloroform- $d$ ) $\delta$ - 69.6.; HRMS (ESI) $\mathrm{m} / \mathrm{z}$ : $[\mathrm{M}+\mathrm{H}]^{+}$calcd for $\mathrm{C}_{17} \mathrm{H}_{15} \mathrm{~F}_{3} \mathrm{~N}^{+}$: 290.1151; found: 290.1136.; $[\alpha]_{\mathrm{D}}{ }^{19}=-37.720\left(c=1.0, \mathrm{CHCl}_{3}\right)$.

The enantiomeric excess of $\mathbf{3 i}$ was determined by chiral HPLC analysis.

Conditions: ChiralPak IA column; hexane $/{ }^{i} \mathrm{PrOH}=98: 2$; flow rate $=0.5 \mathrm{~mL} / \mathrm{min} ; \lambda=$ $220 \mathrm{~nm} ; \mathrm{t}_{\mathrm{R} 1}$ (major) $=13.6 \mathrm{~min} ; \mathrm{t}_{\mathrm{R} 2}$ (minor $)=14.8 \mathrm{~min}$.

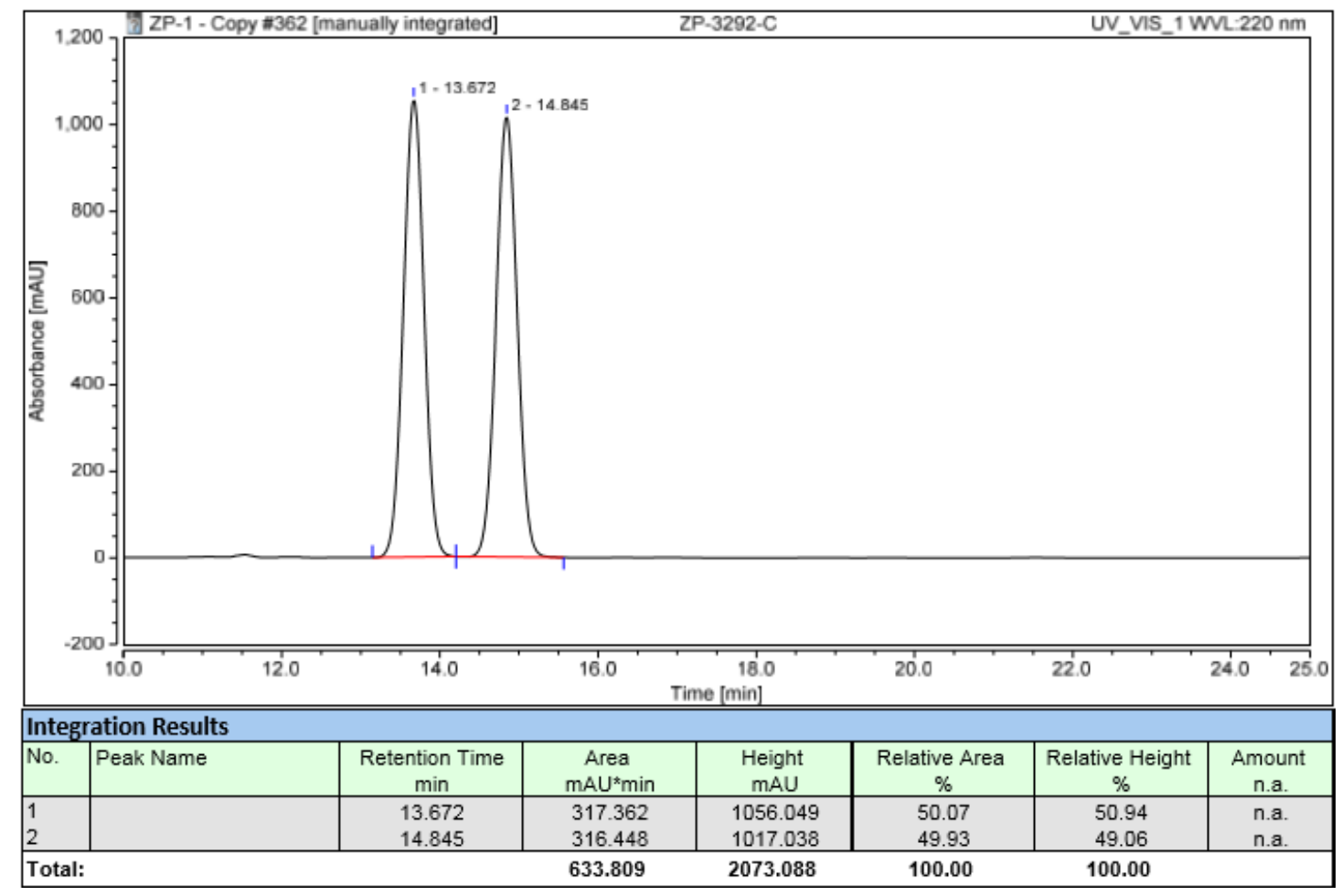




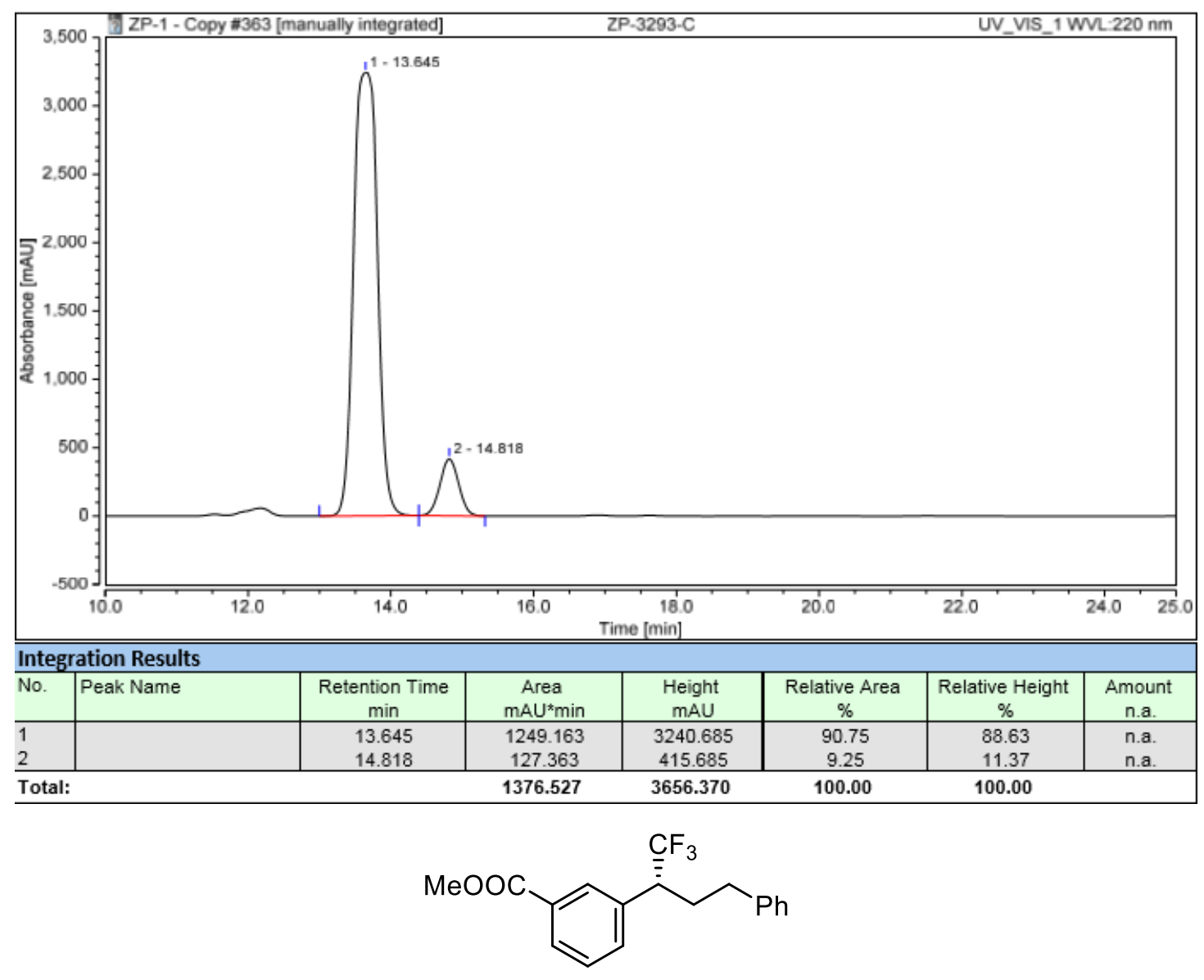

3j

The title compound $\mathbf{3 j}$ was synthesized according to General Procedure (SI 4), and it was purified by column chromatography on silica gel (57\% yield, 92:8 er, $36.6 \mathrm{mg}$, colorless oil).

${ }^{1} \mathrm{H}$ NMR (400 MHz, Chloroform- $d$ ) $\delta 8.06-8.03$ (m, 1H), 7.99 (s, 1H) 7.49 - $7.46(\mathrm{~m}$, 2H), $7.28(\mathrm{t}, J=8.4 \mathrm{~Hz}, 2 \mathrm{H}), 7.21(\mathrm{t}, J=7.3 \mathrm{~Hz}, 1 \mathrm{H}), 7.07(\mathrm{~d}, J=7.3 \mathrm{~Hz}, 2 \mathrm{H}), 3.95$ (s, $3 \mathrm{H}), 3.34-3.24(\mathrm{~m}, 1 \mathrm{H}), 2.61-2.54(\mathrm{~m}, 1 \mathrm{H}), 2.45-2.34(\mathrm{~m}, 2 \mathrm{H}), 2.30-2.20(\mathrm{~m}, 1 \mathrm{H})$. $[\alpha]_{\mathrm{D}}{ }^{19}=-16.813\left(c=0.5, \mathrm{CHCl}_{3}\right)$.

The enantiomeric excess of $\mathbf{3} \mathbf{j}$ was determined by chiral HPLC analysis.

Conditions: ChiralPak IA column; hexane $/{ }^{i} \mathrm{PrOH}=99: 1$; flow rate $=1.0 \mathrm{~mL} / \mathrm{min} ; \lambda=$ $220 \mathrm{~nm} ; \mathrm{t}_{\mathrm{R} 1}($ major $)=6.2 \mathrm{~min} ; \mathrm{t}_{\mathrm{R} 2}($ minor $)=7.1 \mathrm{~min}$. 


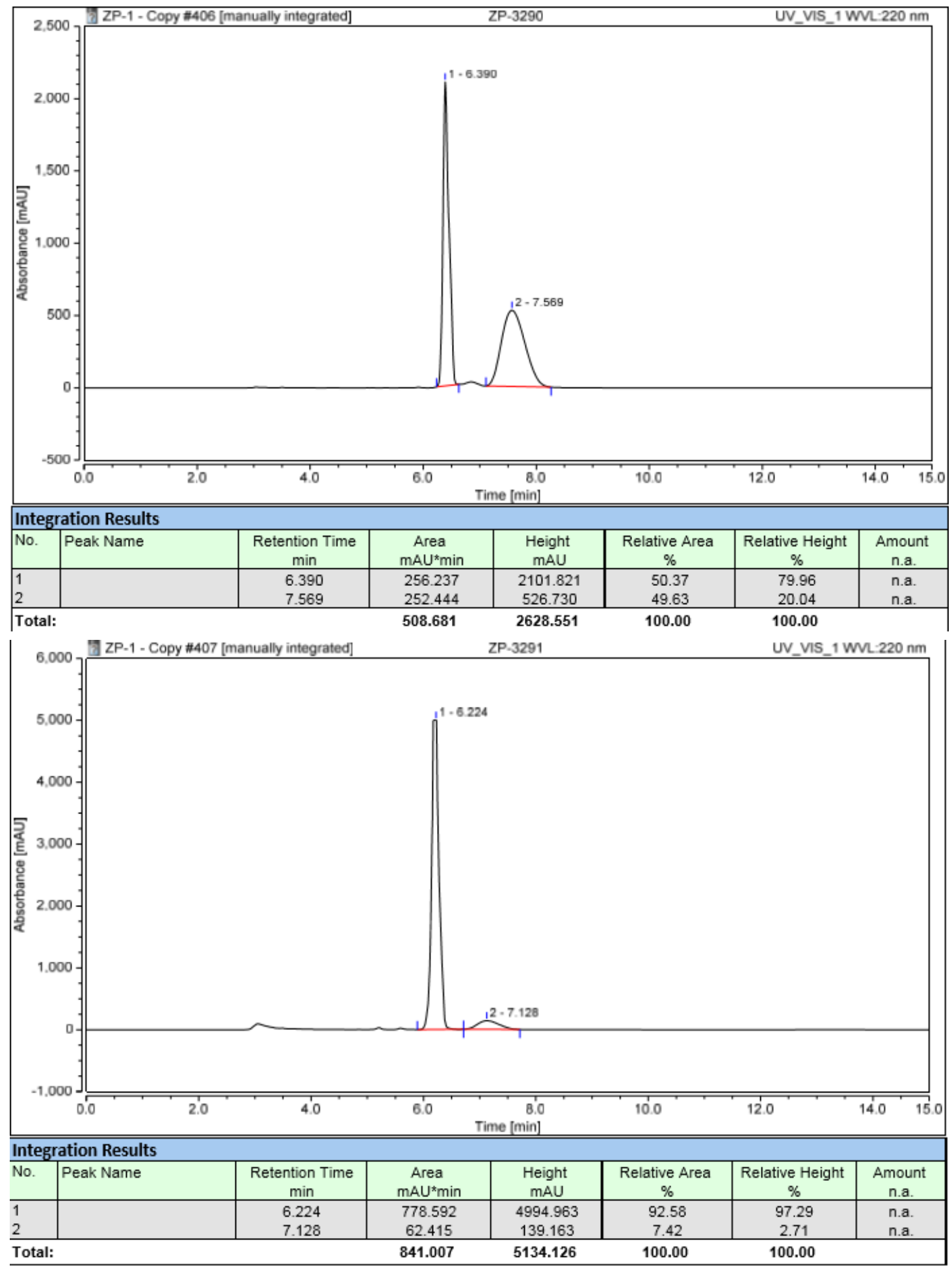<smiles>CC(=O)c1cccc([C@H](CCc2ccccc2)C(F)(F)F)c1</smiles> 
The title compound 3k was synthesized according to General Procedure (SI 4), and it was purified by column chromatography on silica gel (79\% yield, 91.5:8.5 er, 48.5 $\mathrm{mg}$, colorless oil).

${ }^{1} \mathrm{H}$ NMR (400 MHz, Chloroform- $d$ ) $\delta 7.96-7.94(\mathrm{~m}, 1 \mathrm{H}), 7.88(\mathrm{~s}, 1 \mathrm{H}), 7.51(\mathrm{~d}, J=$ $4.6 \mathrm{~Hz}, 2 \mathrm{H}), 7.28$ (t, $J=7.5 \mathrm{~Hz}, 2 \mathrm{H}), 7.21(\mathrm{t}, J=7.3 \mathrm{~Hz}, 1 \mathrm{H}), 7.07(\mathrm{~d}, J=7.4 \mathrm{~Hz}, 2 \mathrm{H})$, $3.36-3.25(\mathrm{~m}, 1 \mathrm{H}), 2.63(\mathrm{~s}, 3 \mathrm{H}), 2.62-2.54(\mathrm{~m}, 1 \mathrm{H}), 2.45-2.35(\mathrm{~m}, 2 \mathrm{H}), 2.30-2.20$ $(\mathrm{m}, 1 \mathrm{H}) ;[\alpha]_{\mathrm{D}}{ }^{19}=-29.323\left(c=1.0, \mathrm{CHCl}_{3}\right)$.

The enantiomeric excess of $\mathbf{3} \mathbf{j}$ was determined by chiral HPLC analysis.

Conditions: ChiralPak AD-H column; hexane $/{ }^{i} \mathrm{PrOH}=85: 15$; flow rate $=0.7 \mathrm{~mL} / \mathrm{min}$; $\lambda=220 \mathrm{~nm} ; \mathrm{t}_{\mathrm{R} 1}$ (major) $=6.2 \mathrm{~min} ; \mathrm{t}_{2}($ minor $)=7.1 \mathrm{~min}$.

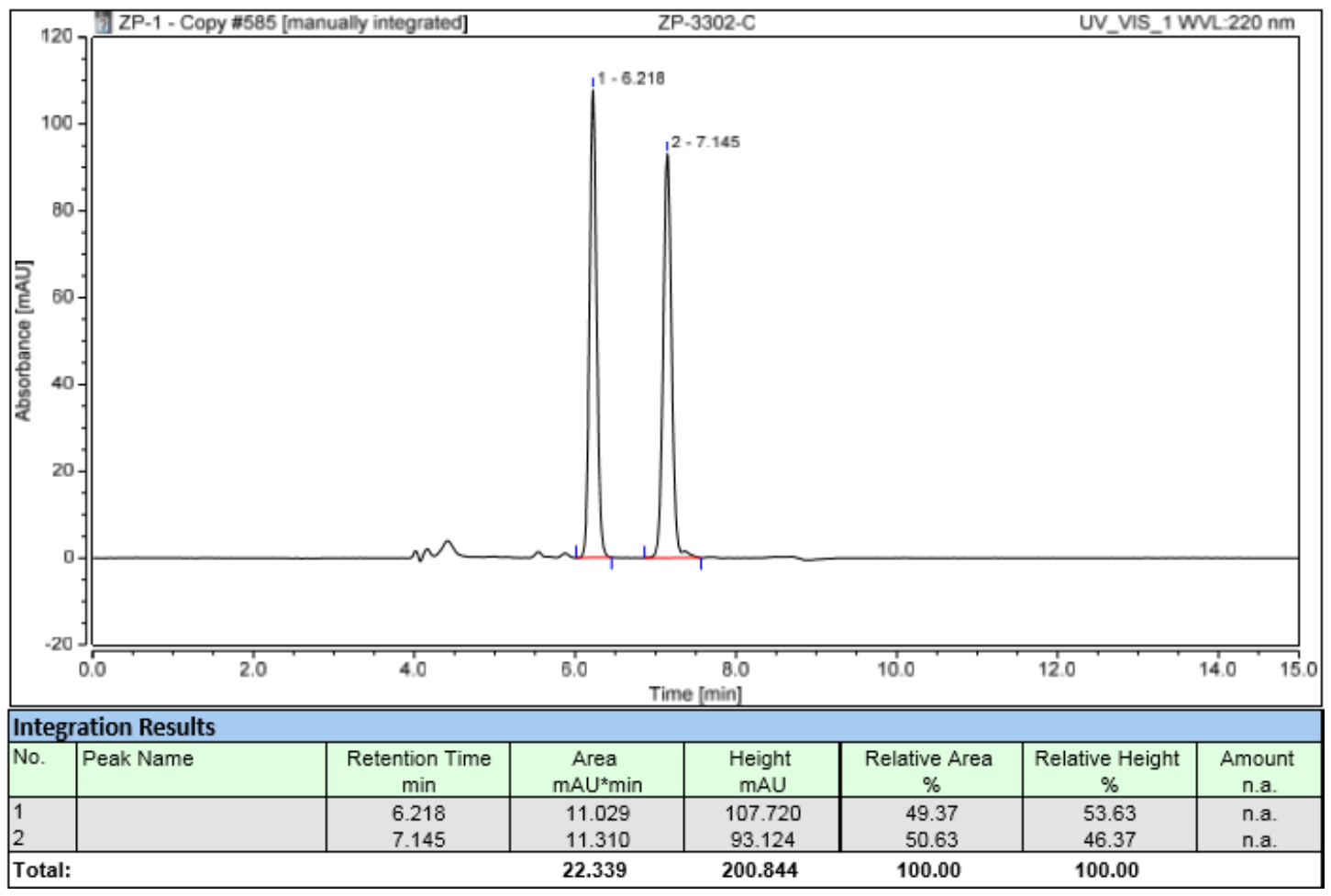




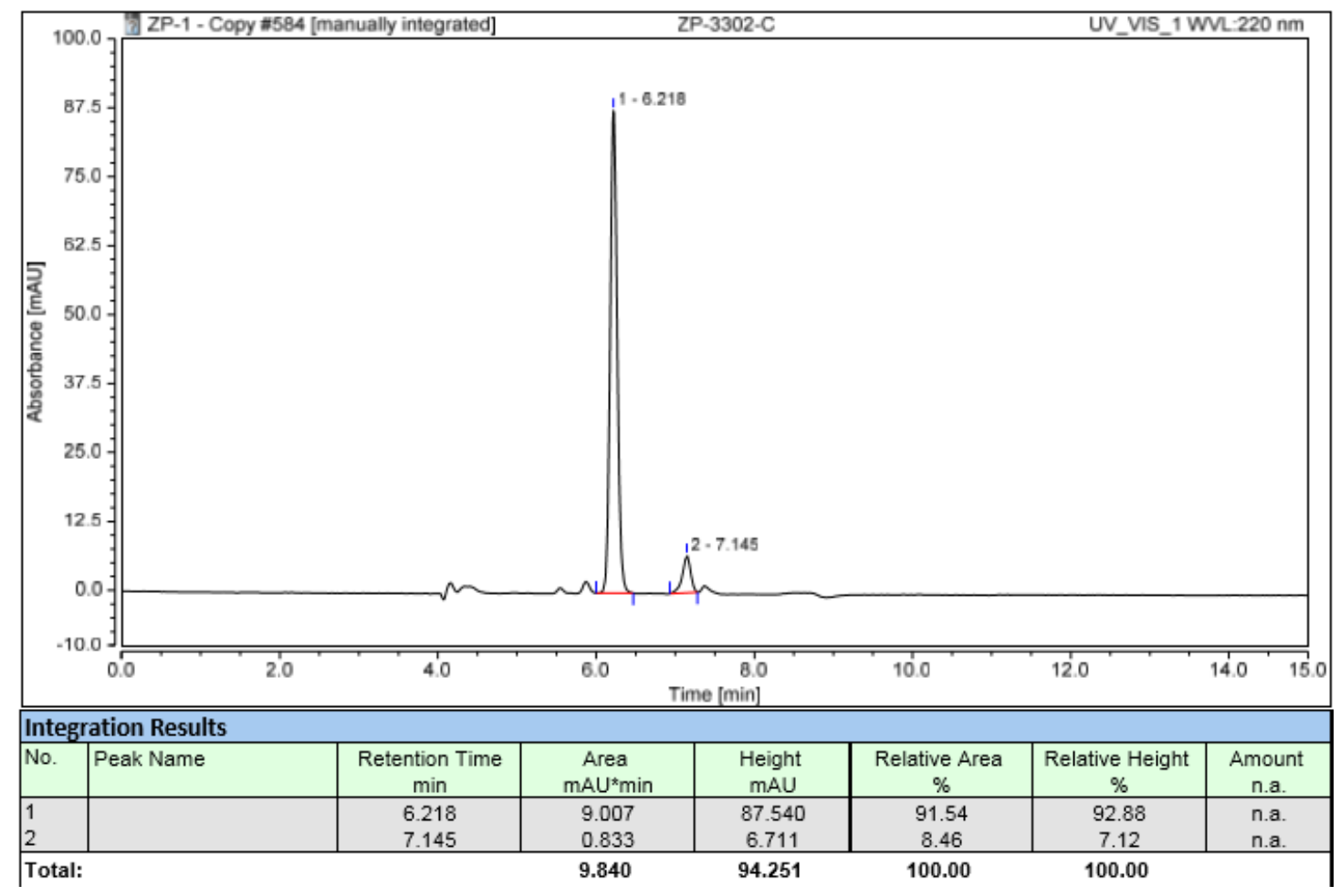<smiles>COc1cccc([C@H](CCc2ccccc2)C(F)(F)F)c1</smiles>

31

The title compound $\mathbf{3 1}$ was synthesized according to General Procedure (SI 4), and it was purified by column chromatography on silica gel (62\% yield, 90:10 er, $36.5 \mathrm{mg}$, colorless oil).

${ }^{1} \mathrm{H}$ NMR (400 MHz, Chloroform- $d$ ) $\delta 7.33-7.25(\mathrm{~m}, 3 \mathrm{H}), 7.20(\mathrm{t}, J=7.3 \mathrm{~Hz}, 1 \mathrm{H})$, $7.10(\mathrm{~d}, J=7.2 \mathrm{~Hz}, 2 \mathrm{H}), 6.91-6.88(\mathrm{~m}, 2 \mathrm{H}), 6.84(\mathrm{~s}, 1 \mathrm{H}), 3.83(\mathrm{~s}, 3 \mathrm{H}), 3.24-3.13(\mathrm{~m}$, $1 \mathrm{H}), 2.63-2.56(\mathrm{~m}, 1 \mathrm{H}), 2.46-2.38(\mathrm{~m}, 1 \mathrm{H}), 2.36-2.28(\mathrm{~m}, 1 \mathrm{H}), 2.24-2.14(\mathrm{~m}, 1 \mathrm{H})$. $[\alpha]_{\mathrm{D}}{ }^{19}=-19.857\left(c=1.0, \mathrm{CHCl}_{3}\right)$.

The enantiomeric excess of $\mathbf{3 l}$ was determined by chiral HPLC analysis.

Conditions: ChiralPak OJ-H column; hexane $/{ }^{i} \mathrm{PrOH}=95: 5$; flow rate $=0.5 \mathrm{~mL} / \mathrm{min}$; $\lambda=220 \mathrm{~nm} ; \mathrm{t}_{\mathrm{R} 1}$ (major) $=17.2 \mathrm{~min} ; \mathrm{t}_{\mathrm{R} 2}($ minor $)=19.6 \mathrm{~min}$. 

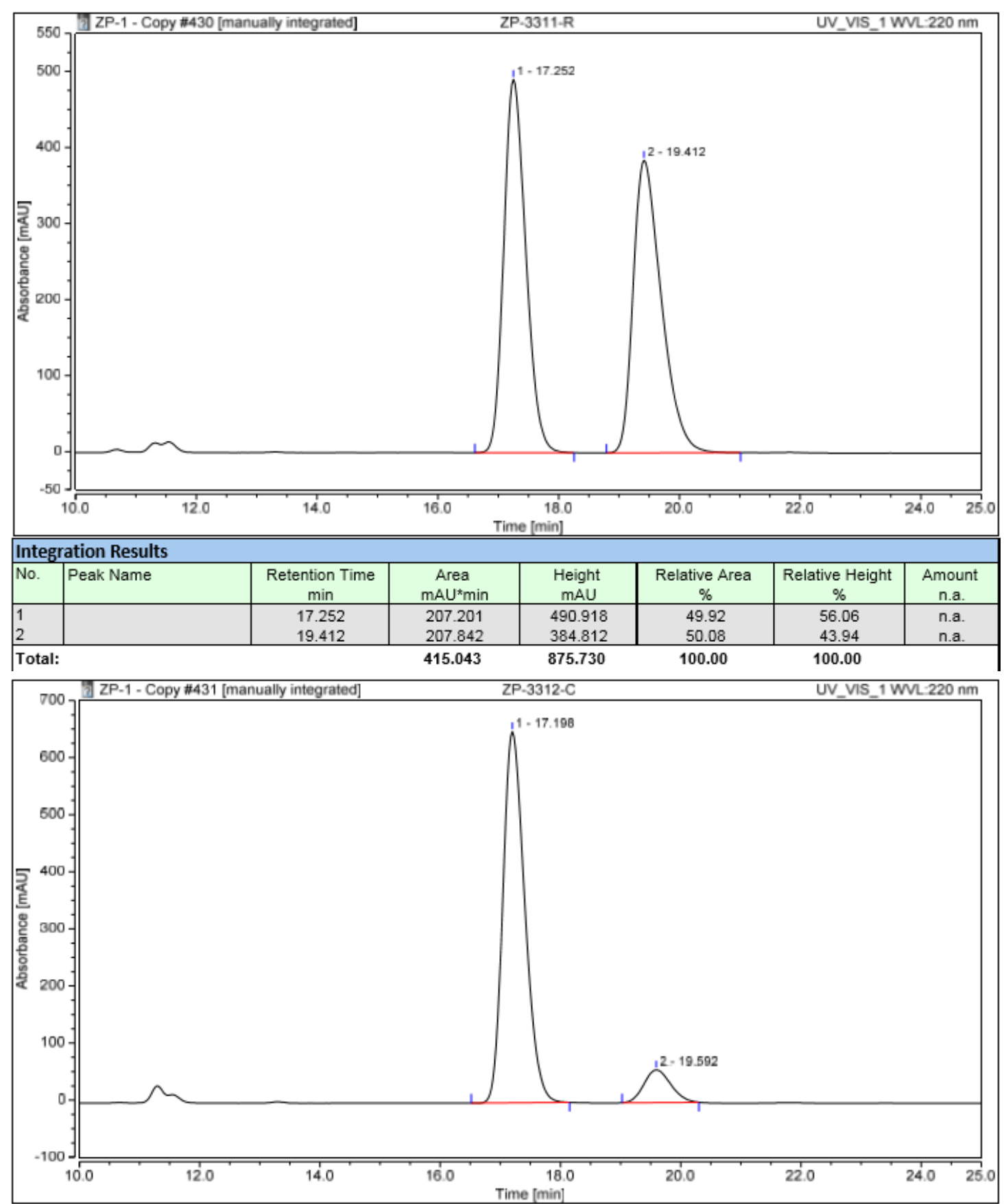

\begin{tabular}{|l|l|c|c|c|c|c|c|}
\hline \multicolumn{2}{|l|}{ Time [min] } \\
\hline \hline Integration Results \\
\hline No. & Peak Name & $\begin{array}{c}\text { Retention Time } \\
\text { min }\end{array}$ & $\begin{array}{c}\text { Area } \\
\text { mAU*min }\end{array}$ & $\begin{array}{c}\text { Height } \\
\text { mAU }\end{array}$ & $\begin{array}{c}\text { Relative Area } \\
\%\end{array}$ & $\begin{array}{c}\text { Relative Height } \\
\%\end{array}$ & $\begin{array}{c}\text { Amount } \\
\text { n.a. }\end{array}$ \\
\hline 1 & & 17.198 & 274.555 & 650.356 & 90.26 & 91.91 & n.a. \\
2 & 19.592 & 29.626 & 57.222 & 9.74 & n.a. \\
\hline
\end{tabular}<smiles>FC(F)(F)[C@H](CCc1ccccc1)c1ccc2c(c1)OCO2</smiles>

$3 m$ 
The title compound 3m was synthesized according to General Procedure (SI 4), and it was purified by column chromatography on silica gel (42\% yield, 90:10 er, $26.1 \mathrm{mg}$, colorless oil).

${ }^{1} \mathrm{H}$ NMR $(600 \mathrm{MHz}$, Chloroform- $d$ ) $\delta 7.30-7.26(\mathrm{~m}, 2 \mathrm{H}), 7.20(\mathrm{t}, J=7.2,1 \mathrm{H}), 7.10$ $(\mathrm{d}, J=7.2,2 \mathrm{H}), 6.82(\mathrm{~d}, J=7.8,1 \mathrm{H}), 6.80(\mathrm{~s}, 1 \mathrm{H}), 6.73(\mathrm{dd}, J=8.0,1.7 \mathrm{~Hz}, 1 \mathrm{H})$, $6.00(\mathrm{~d}, J=1.3 \mathrm{~Hz}, 2 \mathrm{H}), 3.16-3.09(\mathrm{~m}, 1 \mathrm{H}), 2.62-2.58(\mathrm{~m}, 1 \mathrm{H}), 2.43(\mathrm{dt}, J=13.9$, $8.4 \mathrm{~Hz}, 1 \mathrm{H}), 2.32-2.26(\mathrm{~m}, 1 \mathrm{H}), 2.16-2.10(\mathrm{~m}, 1 \mathrm{H}) .{ }^{13} \mathrm{C}$ NMR (151 MHz, Chloroform- $d$ ) $\delta 148.0,147.5,140.5,128.5,128.4,126.8$ (q, $J=276.3 \mathrm{~Hz}), 126.2$, $123.1,108.9$, $108.4,101.2,48.8(\mathrm{q}, J=27.2 \mathrm{~Hz}), 32.41,30.2(\mathrm{q}, J=1.5 \mathrm{~Hz}) ;{ }^{19} \mathrm{~F}$ NMR (565 MHz, Chloroform- $d$ ) $\delta-70.1$; HRMS (ESI) $\mathrm{m} / \mathrm{z}:[\mathrm{M}+\mathrm{H}]^{+}$calcd for $\mathrm{C}_{17} \mathrm{H}_{16} \mathrm{~F}_{3} \mathrm{O}_{2}{ }^{+}$: 309.1114; found: 309.1194.; $[\alpha]_{\mathrm{D}}{ }^{19}=-32.227\left(c=1.0, \mathrm{CHCl}_{3}\right)$.

The enantiomeric excess of $\mathbf{3 m}$ was determined by chiral HPLC analysis.

Conditions: ChiralPak OJ-H column; hexane $/ \mathrm{PrOH}=85: 15$; flow rate $=1.0 \mathrm{~mL} / \mathrm{min}$; $\lambda=220 \mathrm{~nm} ; \mathrm{t}_{\mathrm{R} 1}$ (major) $=6.8 \mathrm{~min} ; \mathrm{t}_{2}$ (minor) $=7.2 \mathrm{~min}$.

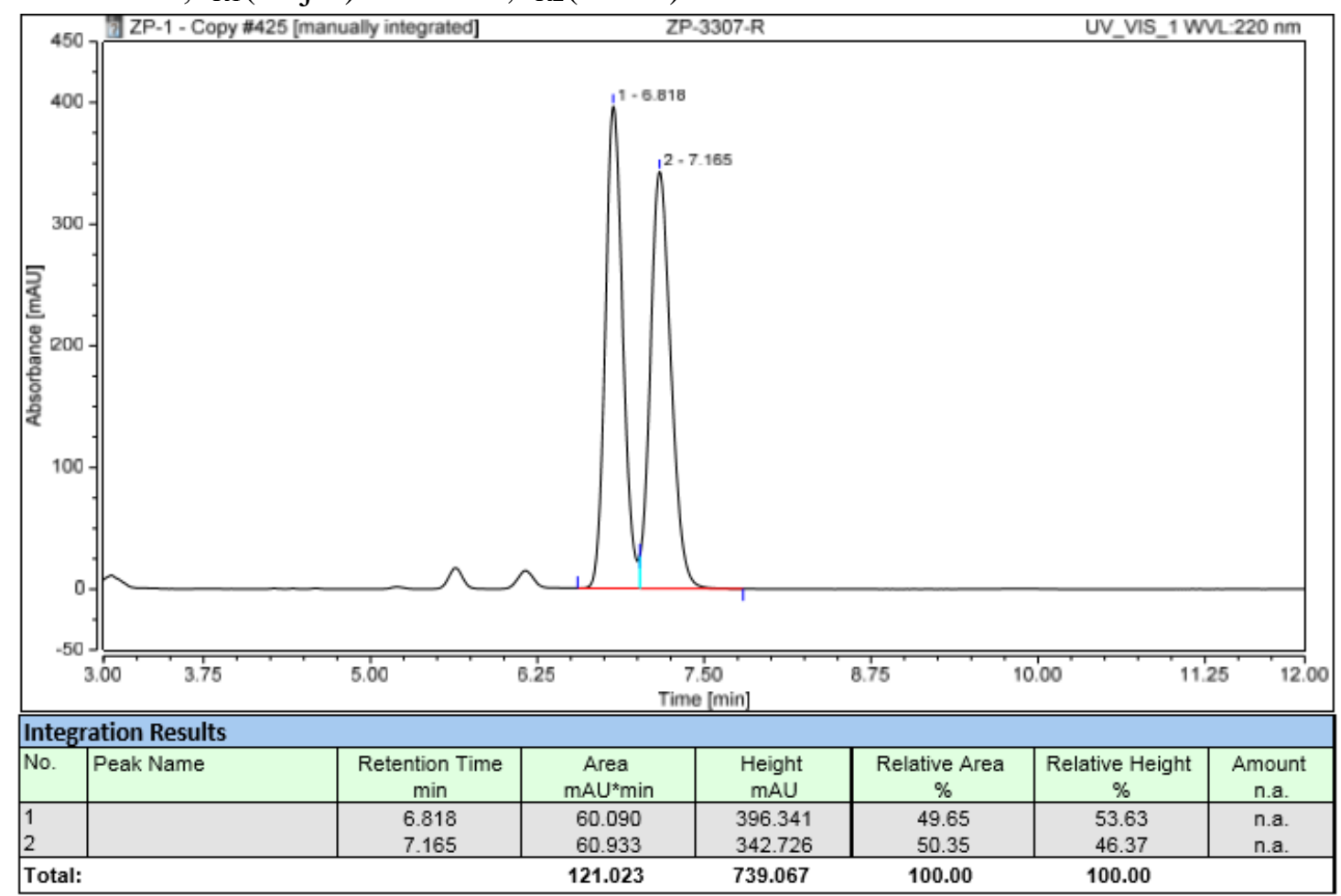




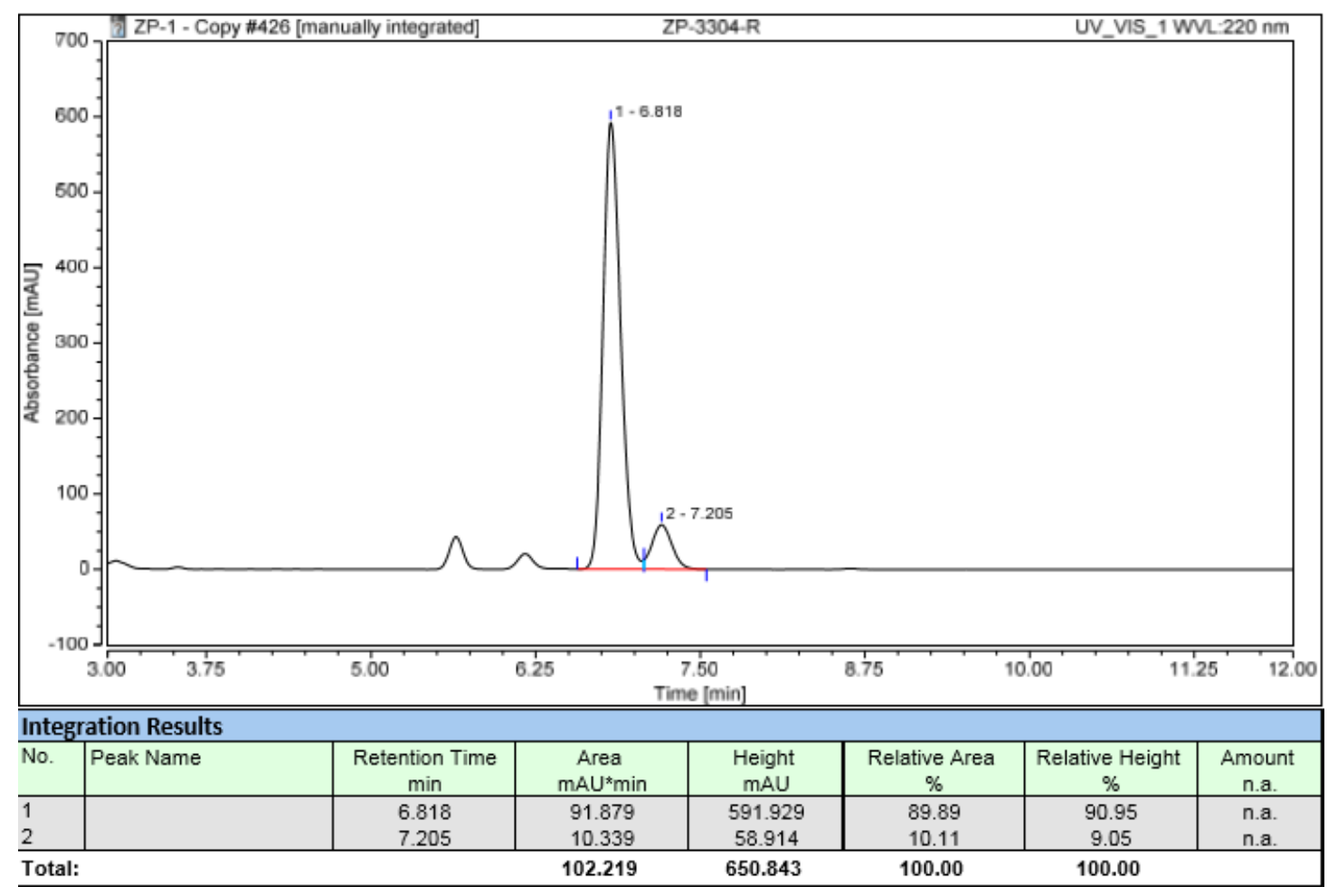<smiles>Cc1cc([C@H](CCc2ccccc2)C(F)(F)F)ccc1C#N</smiles>

$3 n$

The title compound 3n was synthesized according to General Procedure (SI 4), and it was purified by column chromatography on silica gel (71\% yield, 91.5:8.5 er, 43.0 mg, colorless oil).

${ }^{1} \mathrm{H}$ NMR (600 MHz, Chloroform- $d$ ) $\delta 7.51(\mathrm{~d}, J=1.9 \mathrm{~Hz}, 1 \mathrm{H}), 7.40(\mathrm{dd}, J=8.1,1.9$ $\mathrm{Hz}, 1 \mathrm{H}), 7.35(\mathrm{~d}, J=8.0 \mathrm{~Hz}, 1 \mathrm{H}), 7.29(\mathrm{t}, J=7.5 \mathrm{~Hz}, 2 \mathrm{H}), 7.23-7.20(\mathrm{~m}, 1 \mathrm{H}), 7.06$ $(\mathrm{d}, J=7.2 \mathrm{~Hz}, 2 \mathrm{H}), 3.24-3.17(\mathrm{~m}, 1 \mathrm{H}), 2.61-2.56(\mathrm{~m}, 1 \mathrm{H}), 2.58(\mathrm{~s}, 3 \mathrm{H}), 2.42-2.34$ (m, 2H), $2.23-2.15(\mathrm{~m}, 1 \mathrm{H}) ;{ }^{13} \mathrm{C}$ NMR (151 MHz, Chloroform-d) $\delta 142.1,139.8$, $133.4,133.0,130.8,128.6,128.3,126.5,126.4(\mathrm{q}, J=280.9 \mathrm{~Hz}), 117.7,113.4$, $48.3(\mathrm{q}, J=27.2 \mathrm{~Hz}), 32.3,29.7,20.2 ;{ }^{19} \mathrm{~F}$ NMR (565 MHz, Chloroform- $d$ ) $\delta$-69.8; HRMS (ESI) m/z: $[\mathrm{M}+\mathrm{H}]^{+}$calcd for $\mathrm{C}_{18} \mathrm{H}_{17} \mathrm{~F}_{3} \mathrm{~N}^{+}$: 304.1314; found: 304.1308; $[\alpha]_{\mathrm{D}}{ }^{19}=-26.763\left(c=1.0, \mathrm{CHCl}_{3}\right)$.

The enantiomeric excess of $\mathbf{3 m}$ was determined by chiral HPLC analysis.

Conditions: ChiralPak OJ-H column; hexane $/ \mathrm{PrOH}=90: 10$; flow rate $=1.0 \mathrm{~mL} / \mathrm{min}$; $\lambda=220 \mathrm{~nm} ; \mathrm{t}_{\mathrm{R} 1}($ major $)=8.9 \mathrm{~min} ; \mathrm{t}_{\mathrm{R} 2}($ minor $)=8.1 \mathrm{~min}$. 

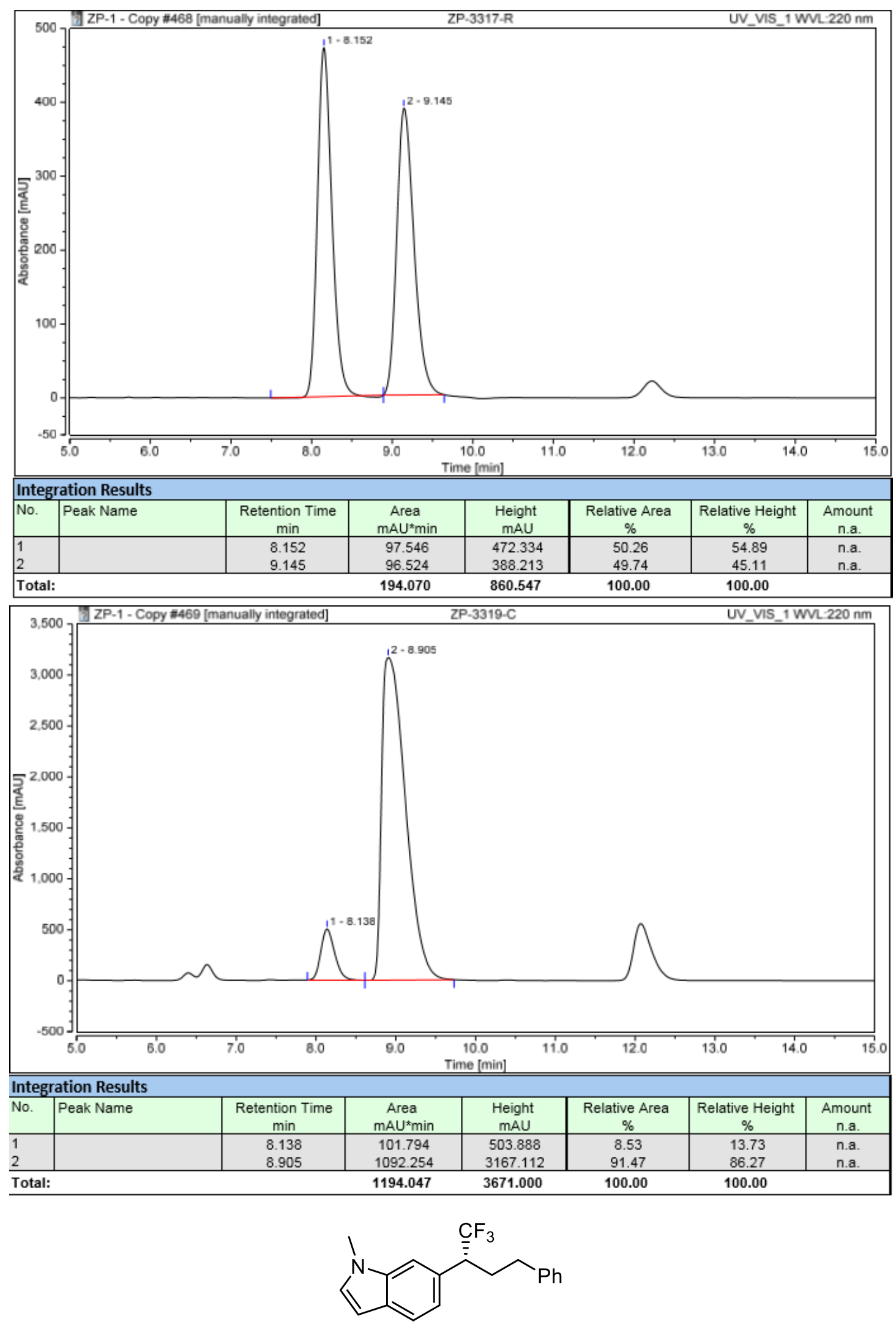
The title compound 3o was synthesized according to General Procedure (SI 4), and it was purified by column chromatography on silica gel (57\% yield, 87:13 er, $36.4 \mathrm{mg}$, colorless oil).

${ }^{1} \mathrm{H}$ NMR (600 MHz, Chloroform- $d$ ) $\delta 7.56(\mathrm{~d}, J=1.6 \mathrm{~Hz}, 1 \mathrm{H}), 7.34(\mathrm{~d}, J=8.5 \mathrm{~Hz}$, $1 \mathrm{H}), 7.32$ - $7.24(\mathrm{~m}, 2 \mathrm{H}), 7.22$ - $7.14(\mathrm{~m}, 2 \mathrm{H}), 7.12-7.07(\mathrm{~m}, 3 \mathrm{H}), 6.53-6.47(\mathrm{~m}, 1 \mathrm{H})$, $3.81(\mathrm{~s}, 3 \mathrm{H}), 3.31(\mathrm{~m}, 1 \mathrm{H}), 2.59(\mathrm{~m}, 1 \mathrm{H}), 2.47-2.33(\mathrm{~m}, 2 \mathrm{H}), 2.29(\mathrm{~m}, 1 \mathrm{H}) ;[\alpha]_{\mathrm{D}}{ }^{19}=-$ $16.141\left(c=1.0, \mathrm{CHCl}_{3}\right)$.

The enantiomeric excess of $\mathbf{3 o}$ was determined by chiral HPLC analysis.

Conditions: ChiralPak OJ-H column; hexane $/ \mathrm{PrOH}=75: 25$; flow rate $=1.0 \mathrm{~mL} / \mathrm{min}$; $\lambda=220 \mathrm{~nm} ; \mathrm{t}_{\mathrm{R} 1}$ (major) $=23.5 \mathrm{~min} ; \mathrm{t}_{\mathrm{R} 2}$ (minor) $=33.4 \mathrm{~min}$.

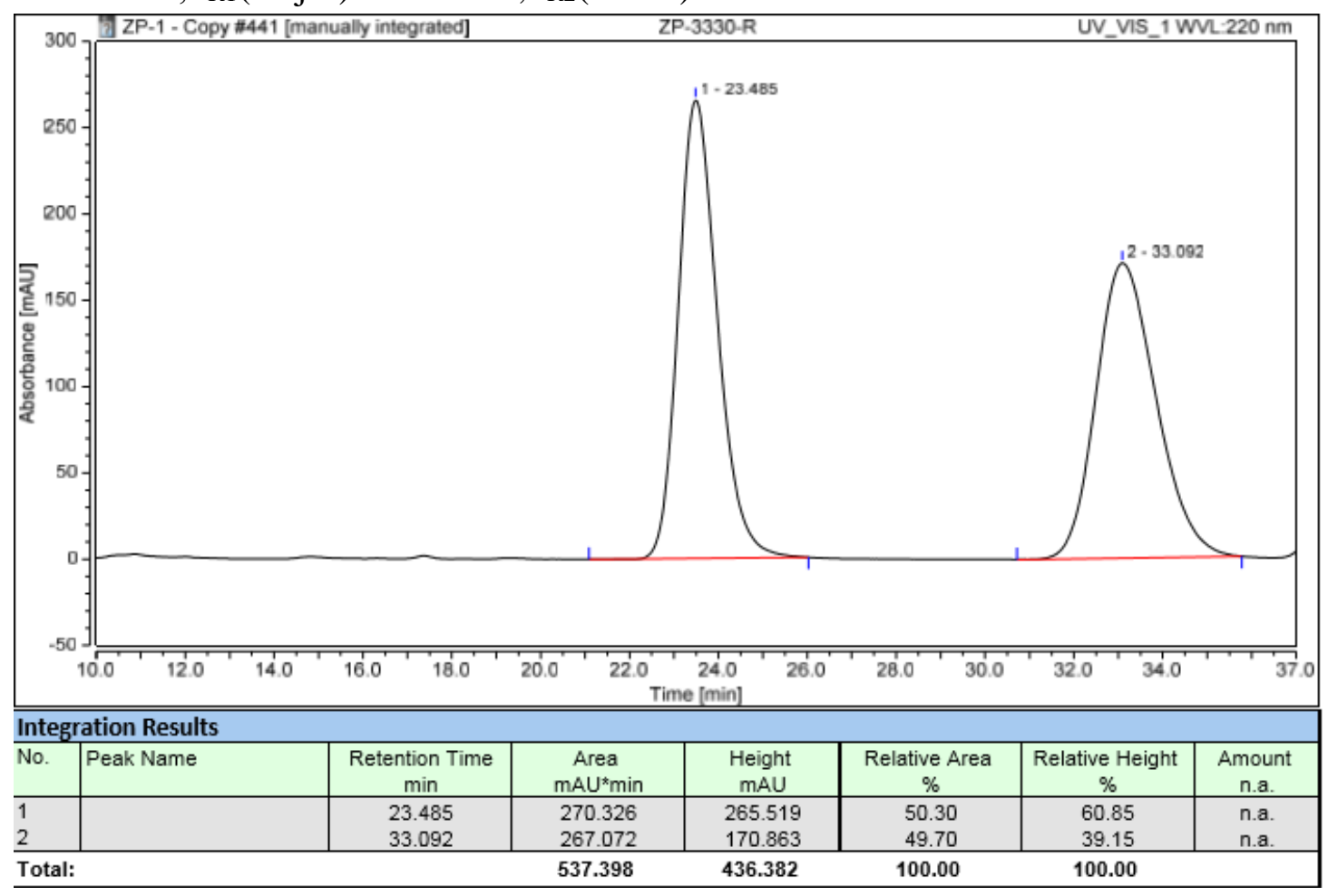




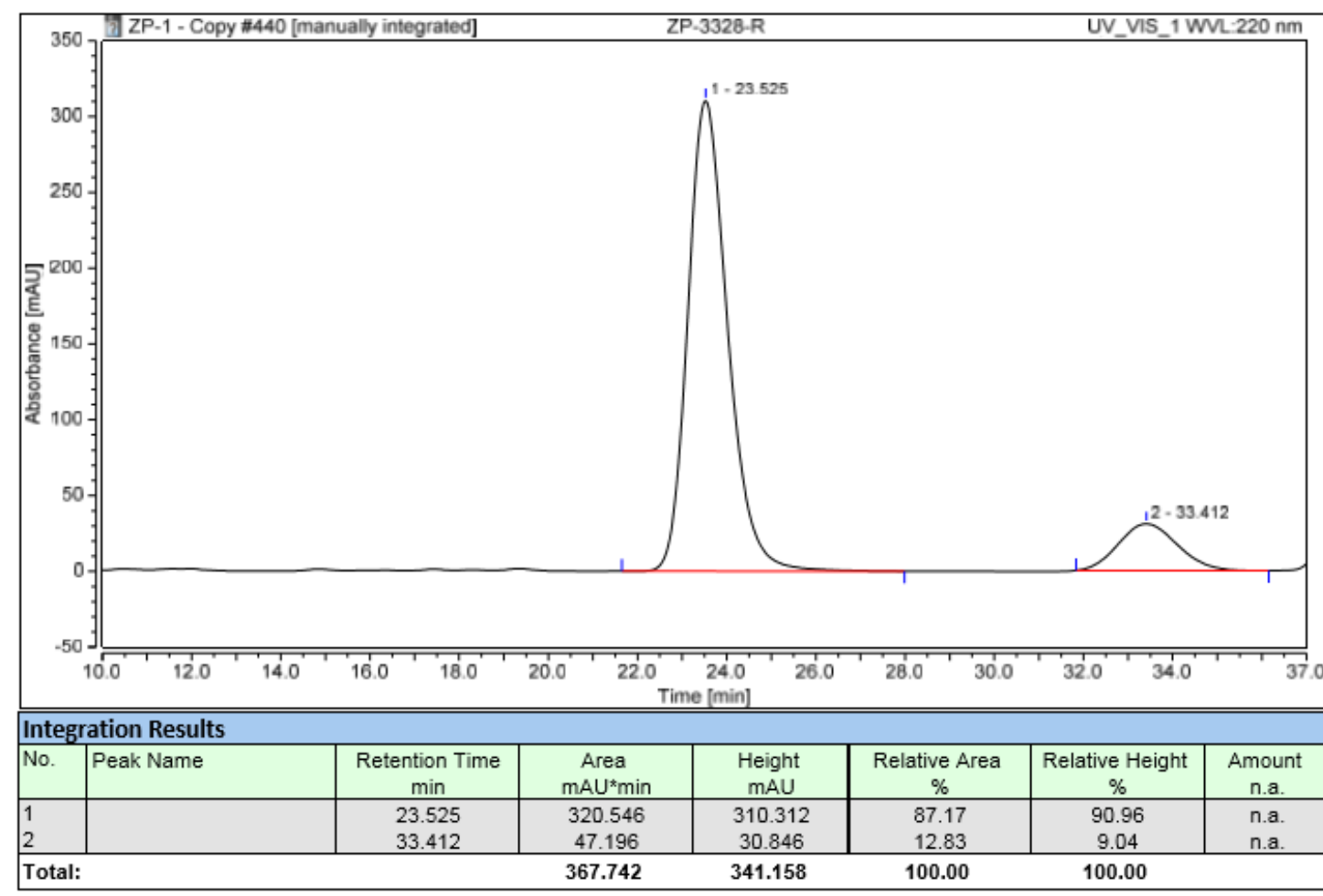<smiles>Fc1cc([C@H](CCc2ccccc2)C(F)(F)F)ccn1</smiles>

$3 p$

The title compound $\mathbf{3 p}$ was synthesized according to General Procedure (SI 4), and it was purified by column chromatography on silica gel (67\% yield, 93:7 er, $38.0 \mathrm{mg}$, colorless oil).

${ }^{1} \mathrm{H}$ NMR (600 MHz, Chloroform- $d$ ) $\delta 8.26(\mathrm{~d}, J=5.1 \mathrm{~Hz}, 1 \mathrm{H}), 7.30(\mathrm{t}, J=7.6 \mathrm{~Hz}$, $2 \mathrm{H}), 7.26-7.22(\mathrm{~m}, 1 \mathrm{H}), 7.12(\mathrm{~d}, J=5.2 \mathrm{~Hz}, 1 \mathrm{H}), 7.08(\mathrm{~d}, J=7.2 \mathrm{~Hz}, 2 \mathrm{H}), 6.87(\mathrm{~s}$, $1 \mathrm{H}), 3.30-3.24(\mathrm{~m}, 1 \mathrm{H}), 2.64-2.59(\mathrm{~m}, 1 \mathrm{H}), 2.46-2.37(\mathrm{~m}, 2 \mathrm{H}), 2.23-2.16(\mathrm{~m}$, $1 \mathrm{H}) ;{ }^{13} \mathrm{C}$ NMR $(151 \mathrm{MHz}$, Chloroform- $d) \delta 164.1(\mathrm{~d}, J=240.1 \mathrm{~Hz}), 149.3,148.3(\mathrm{~d}, J$ $=15.1 \mathrm{~Hz}), 139.5,128.7,128.3,126.6,125.9(\mathrm{q}, J=280.9 \mathrm{~Hz}), 125.0,121.9(\mathrm{~d}, J$ $=37.9 \mathrm{~Hz}), 110.2(\mathrm{~d}, J=39.3 \mathrm{~Hz}), 48.5(\mathrm{dq}, J=27.2,3.0 \mathrm{~Hz}), 32.2,29.7(\mathrm{q}, J=1.5$ $\mathrm{Hz}$ ); ${ }^{19} \mathrm{~F}$ NMR (565 MHz, Chloroform- $d$ ) $\delta$ - 67.0, - 69.1; HRMS (ESI) m/z: $[\mathrm{M}+\mathrm{H}]^{+}$calcd for $\mathrm{C}_{15} \mathrm{H}_{14} \mathrm{~F}_{4} \mathrm{~N}^{+}: 284.1058$; found: 284.1057.; $[\alpha]_{\mathrm{D}}{ }^{19}=-36.816(c=1.0$, $\mathrm{CHCl}_{3}$ ).

The enantiomeric excess of $\mathbf{3 p}$ was determined by chiral HPLC analysis.

Conditions: ChiralPak OJ-H column; hexane $/{ }^{i} \mathrm{PrOH}=90: 10$; flow rate $=0.5 \mathrm{~mL} / \mathrm{min}$; $\lambda=220 \mathrm{~nm} ; \mathrm{t}_{\mathrm{R} 1}($ major $)=16.5 \mathrm{~min} ; \mathrm{t}_{\mathrm{R} 2}($ minor $)=15.8 \mathrm{~min}$. 

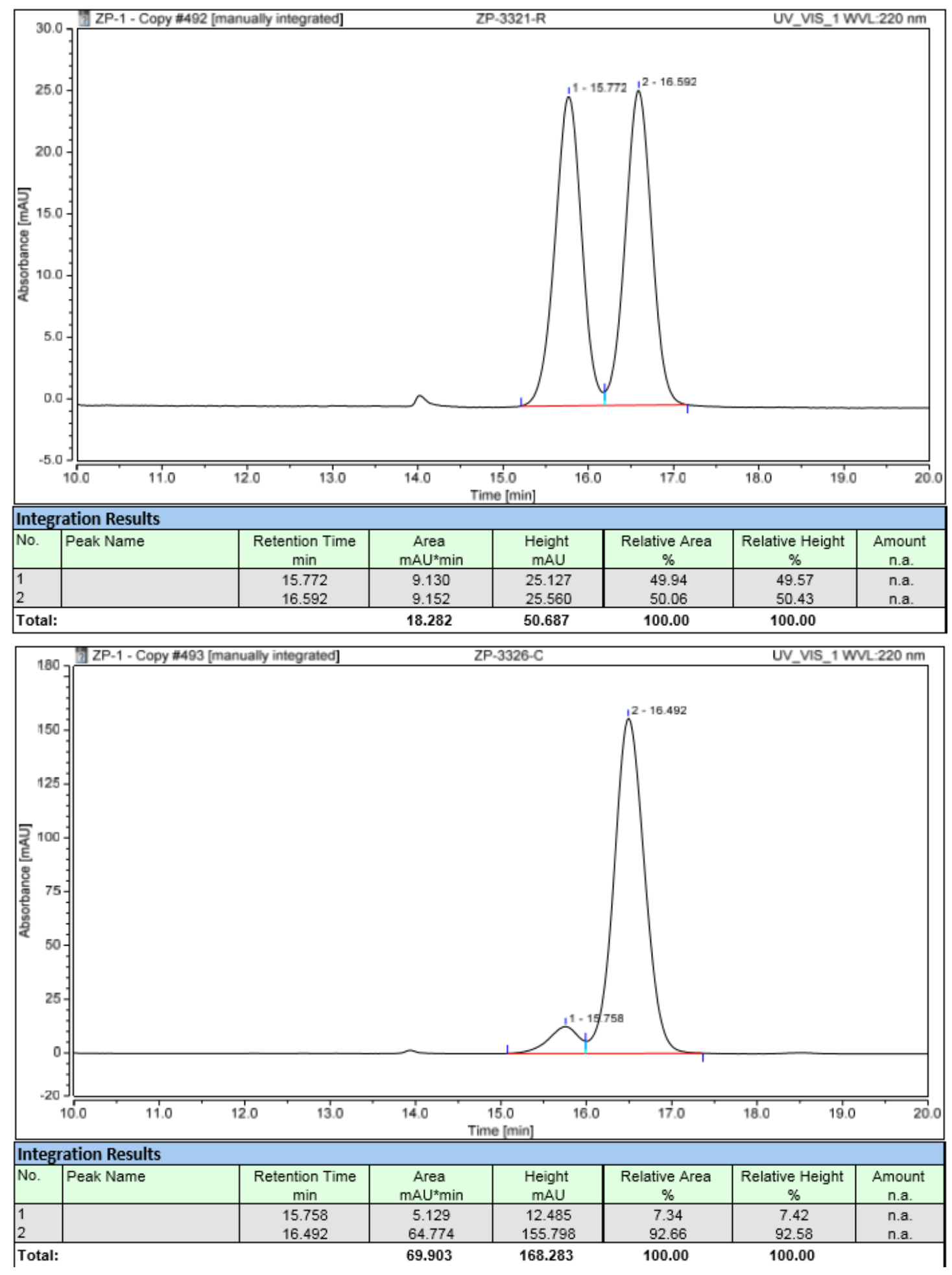<smiles>N#Cc1ccc([C@H](CCCOC(=O)OCc2ccccc2)C(F)(F)F)cc1</smiles>

$3 q$ 
The title compound $\mathbf{3 q}$ was synthesized according to General Procedure (SI 4), and it was purified by column chromatography on silica gel (77\% yield, 91:9 er, $53.5 \mathrm{mg}$, colorless oil).

${ }^{1} \mathrm{H}$ NMR (600 MHz, Chloroform- $d$ ) $\delta 8.00(\mathrm{dd}, J=8.2,1.4 \mathrm{~Hz}, 2 \mathrm{H}), 7.73-7.63(\mathrm{~m}$, $2 \mathrm{H}), 7.63-7.54(\mathrm{~m}, 1 \mathrm{H}), 7.50-7.38(\mathrm{~m}, 4 \mathrm{H}), 4.29(\mathrm{t}, J=6.3 \mathrm{~Hz}, 2 \mathrm{H}), 3.45-3.33(\mathrm{~m}$, 1H), $2.24(\mathrm{~m}, 1 \mathrm{H}), 2.02(\mathrm{~m}, 1 \mathrm{H}), 1.75-1.57(\mathrm{~m}, 2 \mathrm{H}) .{ }^{13} \mathrm{C}$ NMR (151 MHz, Chloroform- $d) \delta 166.4,139.6,133.1,132.59$, $129.9,129.8,129.5$, $128.4,126.1$ $(\mathrm{q}, J=279.4 \mathrm{~Hz}), 118.2,112.6,63.7,49.8(\mathrm{q}, J=27.2 \mathrm{~Hz}), 26.0,25.3(\mathrm{q}, J=3.0$ $\mathrm{Hz}$ ); NMR (565 MHz, Chloroform- $d$ ) $\delta$ - 69.4; HRMS (ESI) m/z: $[\mathrm{M}+\mathrm{H}]^{+}$calcd for $\mathrm{C}_{19} \mathrm{H}_{17} \mathrm{~F}_{3} \mathrm{NO}_{2}{ }^{+}$: 348.1218; found: 348.1206.; $[\alpha]_{\mathrm{D}}{ }^{19}=-9.738\left(c=0.5, \mathrm{CHCl}_{3}\right)$.

The enantiomeric excess of $\mathbf{3 q}$ was determined by chiral HPLC analysis.

Conditions: ChiralPak IA column; hexane $/{ }^{i} \mathrm{PrOH}=97: 3$; flow rate $=1.0 \mathrm{~mL} / \mathrm{min} ; \lambda=$ $220 \mathrm{~nm} ; \mathrm{t}_{\mathrm{R} 1}$ (major) $=17.9 \mathrm{~min} ; \mathrm{t}_{\mathrm{R} 2}($ minor $)=20.5 \mathrm{~min}$.

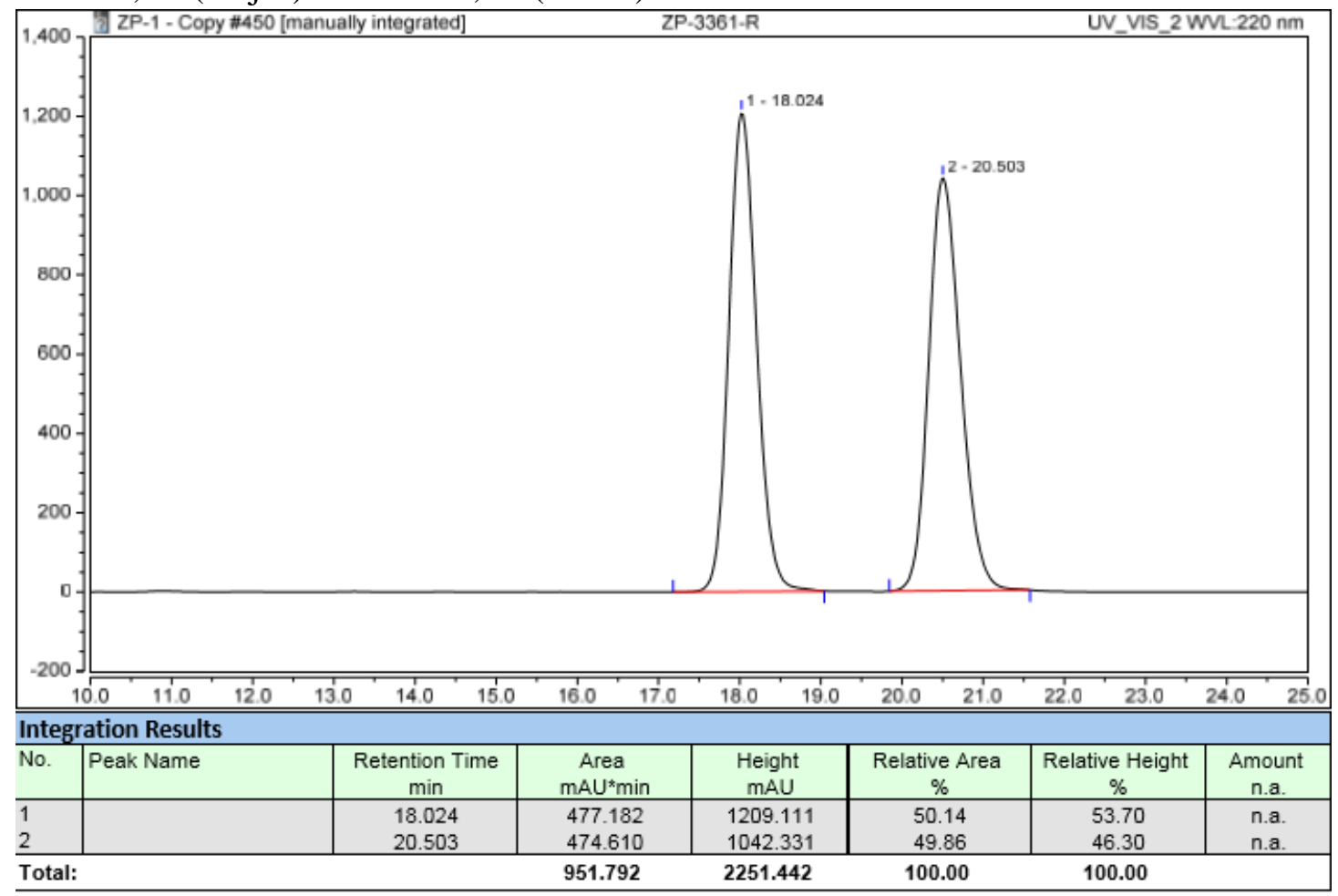




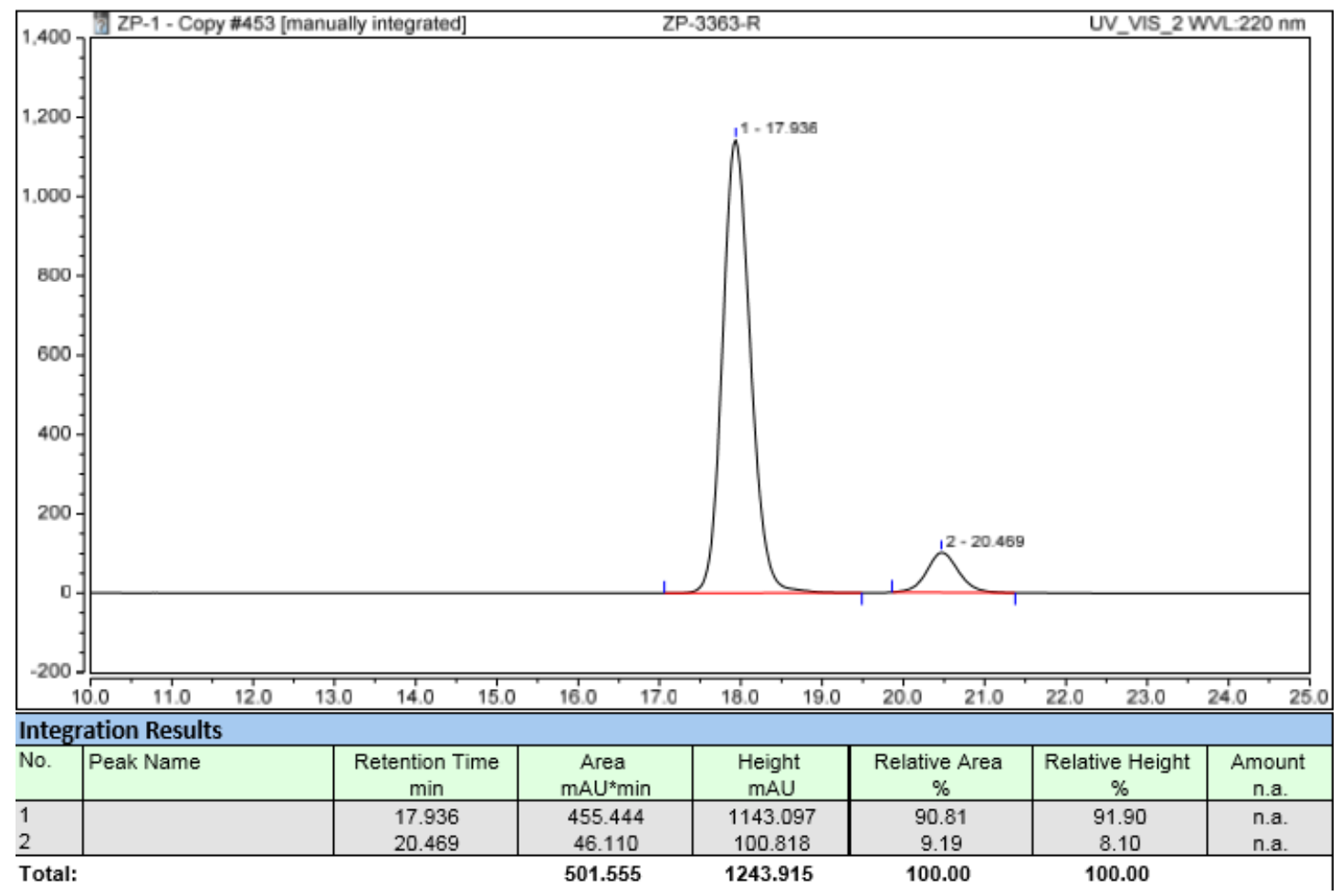<smiles>CC(=O)c1ccc([C@@H](CCCOC(=O)c2ccccc2)C(F)(F)F)cc1</smiles>

$3 r$

The title compound 3r was synthesized according to General Procedure (SI 4), and it was purified by column chromatography on silica gel (76\% yield, 89:11 er, $55.3 \mathrm{mg}$, colorless oil).

${ }^{1} \mathrm{H}$ NMR (600 MHz, Chloroform- $d$ ) $\delta 8.03$ - 7.98 (m, 2H), 7.98 - 7.94 (m, 2H), 7.60 $7.54(\mathrm{~m}, 1 \mathrm{H}), 7.50-7.38(\mathrm{~m}, 4 \mathrm{H}), 4.29(\mathrm{t}, J=6.4 \mathrm{~Hz}, 2 \mathrm{H}), 3.39(\mathrm{~m}, 1 \mathrm{H}), 2.61(\mathrm{~s}, 3 \mathrm{H})$, $2.23(\mathrm{~m}, 1 \mathrm{H}), 2.05(\mathrm{~m}, 1 \mathrm{H}), 1.74-1.59(\mathrm{~m}, 2 \mathrm{H}) ;[\alpha]_{\mathrm{D}}{ }^{19}=-8.354\left(c=1.0, \mathrm{CHCl}_{3}\right)$.

The enantiomeric excess of $\mathbf{3 r}$ was determined by chiral HPLC analysis.

Conditions: ChiralPak IA column; hexane $/{ }^{i} \mathrm{PrOH}=97: 3$; flow rate $=1.0 \mathrm{~mL} / \mathrm{min} ; \lambda=$ $220 \mathrm{~nm} ; \mathrm{t}_{\mathrm{R} 1}($ major $)=21.5 \mathrm{~min} ; \mathrm{t}_{\mathrm{R} 2}($ minor $)=23.9 \mathrm{~min}$. 

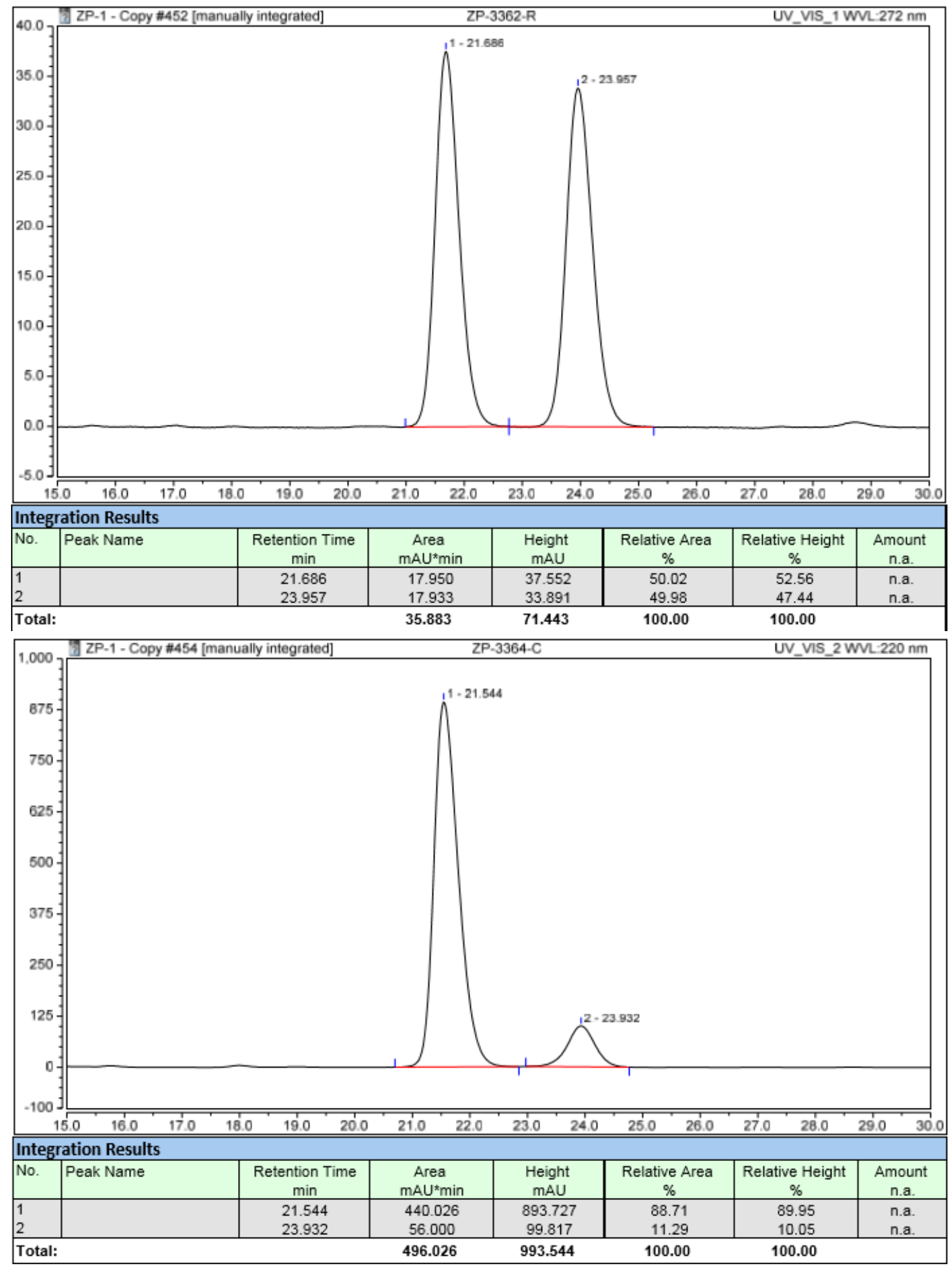<smiles>CC(=O)c1ccc([C@H](CCN2C(=O)c3ccccc3C2=O)C(F)(F)F)cc1</smiles>

3s 
The title compound 3s was synthesized according to General Procedure (SI 4), and it was purified by column chromatography on silica gel (67\% yield, 86:14 er, $50.2 \mathrm{mg}$, colorless oil).

${ }^{1} \mathrm{H}$ NMR (600 MHz, Chloroform- $d$ ) $\delta 7.83$ - $7.82(\mathrm{~m}, 2 \mathrm{H}), 7.75$ - $7.72(\mathrm{~m}, 2 \mathrm{H}), 7.67$ $7.65(\mathrm{~m}, 2 \mathrm{H}), 7.41(\mathrm{~d}, J=8.1 \mathrm{~Hz}, 2 \mathrm{H}), 3.73-3.63(\mathrm{~m}, 2 \mathrm{H}), 3.48-3.41(\mathrm{~m}, 1 \mathrm{H}), 2.50$ (s, 3H), $2.50-2.45(\mathrm{~m}, 1 \mathrm{H}), 2.40-2.35(\mathrm{~m}, 1 \mathrm{H}) ;{ }^{13} \mathrm{C}$ NMR (151 MHz, Chloroform- $d$ ) $\delta 197.2,168.0,138.6,136.8,134.0,131.7,129.4,128.6,126.1$ (q, $J=277.8 \mathrm{~Hz})$, $123.2,48.3(\mathrm{q}, J=27.2 \mathrm{~Hz}), 35.6,27.0(\mathrm{q}, J=1.6 \mathrm{~Hz}), 26.5$; NMR $(565 \mathrm{MHz}$, Chloroform- $d$ ) $\delta$-70.0; HRMS (ESI) $\mathrm{m} / \mathrm{z}: \quad[\mathrm{M}+\mathrm{H}]^{+}$calcd for $\mathrm{C}_{20} \mathrm{H}_{17} \mathrm{~F}_{3} \mathrm{NO}_{3}{ }^{+}$: 376.1155; found: 376.1165.; $[\alpha]_{\mathrm{D}}{ }^{19}=-21.119 .\left(c=1.0, \mathrm{CHCl}_{3}\right)$.

The enantiomeric excess of $3 \mathrm{~s}$ was determined by chiral HPLC analysis.

Conditions: ChiralPak IC column; hexane $/{ }^{i} \mathrm{PrOH}=90: 10$; flow rate $=1.0 \mathrm{~mL} / \mathrm{min} ; \lambda=$ $220 \mathrm{~nm} ; \mathrm{t}_{\mathrm{R} 1}($ major $)=27.8 \mathrm{~min} ; \mathrm{t}_{\mathrm{R} 2}($ minor $)=24.4 \mathrm{~min}$.

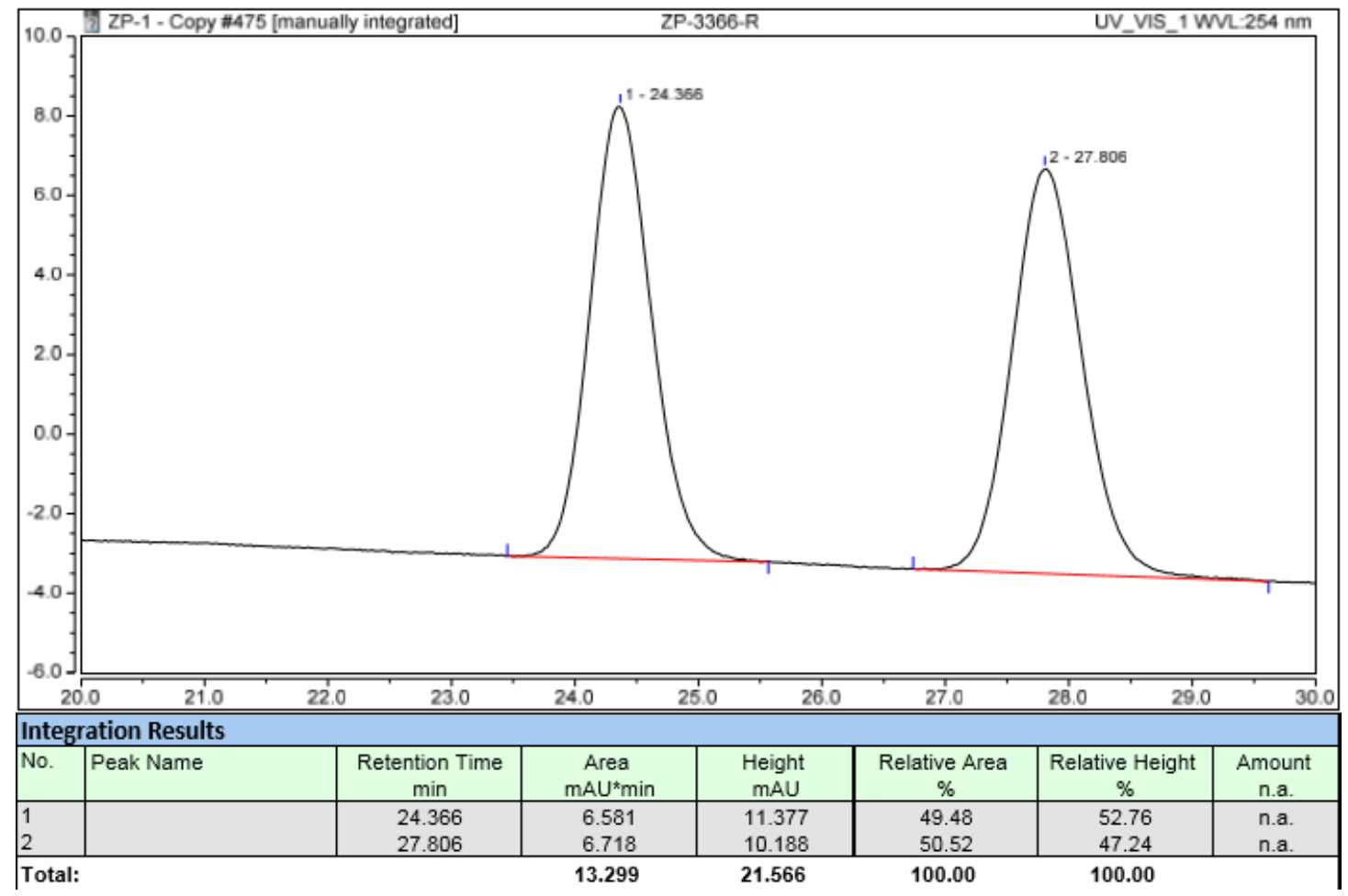




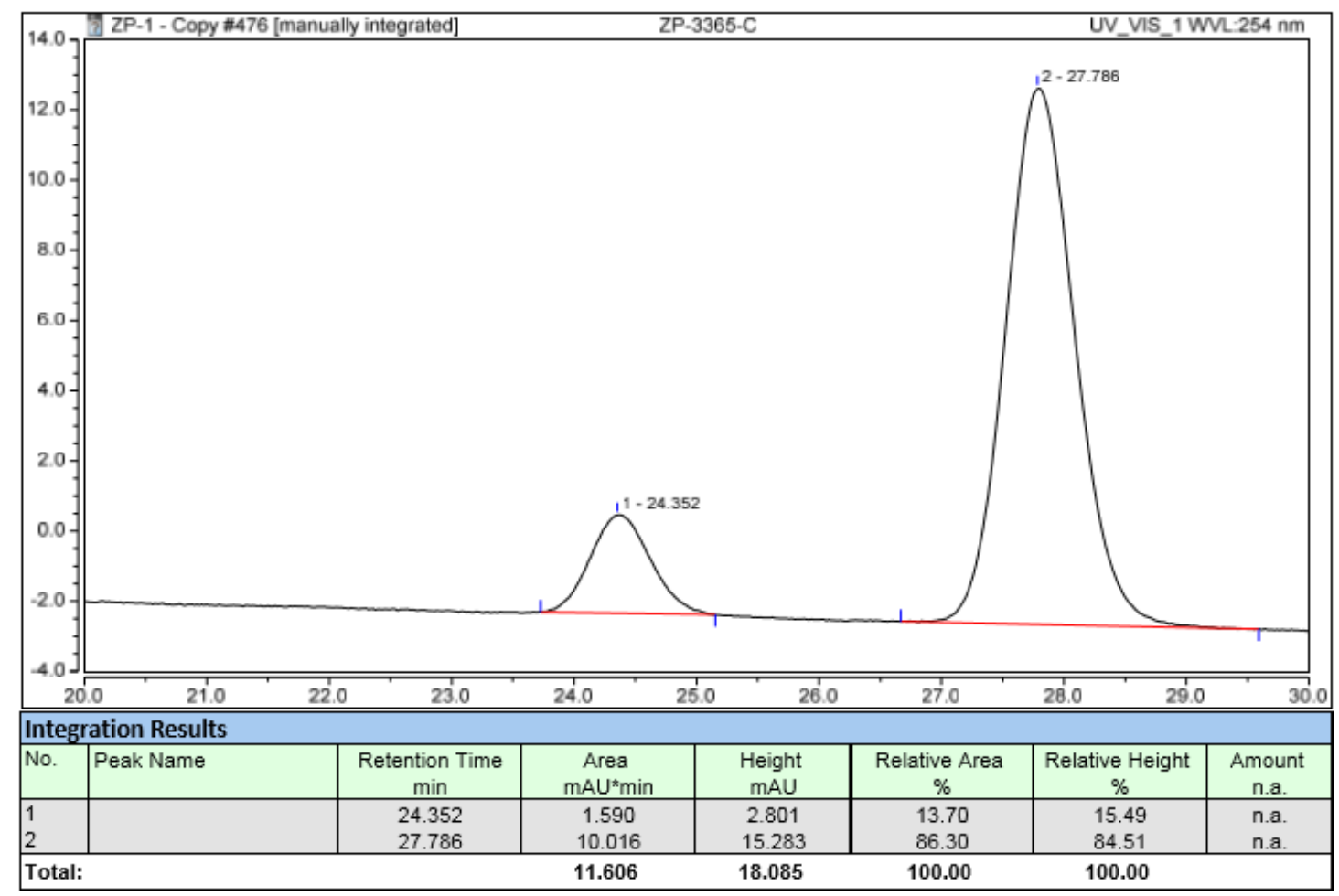<smiles>CC(=O)c1ccc(C(CCCO)C(F)(F)F)cc1</smiles>

3t

The title compound $3 \mathrm{t}$ was synthesized according to General Procedure (SI 4), and it was purified by column chromatography on silica gel (78\% yield, 93:7 er, $40.5 \mathrm{mg}$, colorless oil).

${ }^{1} \mathrm{H}$ NMR (600 MHz, Chloroform- $d$ ) $\delta 8.01-7.91(\mathrm{~m}, 2 \mathrm{H}), 7.41(\mathrm{~d}, J=8.1 \mathrm{~Hz}, 2 \mathrm{H})$, $3.63(\mathrm{t}, J=6.2 \mathrm{~Hz}, 2 \mathrm{H}), 3.41-3.34(\mathrm{~m}, 1 \mathrm{H}), 2.61(\mathrm{~s}, 3 \mathrm{H}), 2.20-2.14(\mathrm{~m}, 1 \mathrm{H}), 2.02-$ $1.95(\mathrm{~m}, 1 \mathrm{H}), 1.49-1.38(\mathrm{~m}, 2 \mathrm{H}) ;[\alpha]_{\mathrm{D}}{ }^{19}=-21.057 .\left(c=1.0, \mathrm{CHCl}_{3}\right)$.

The enantiomeric excess of $\mathbf{3 t}$ was determined by chiral HPLC analysis.

Conditions: ChiralPak OJ-H column; hexane $/{ }^{i} \mathrm{PrOH}=85: 15$; flow rate $=1.0 \mathrm{~mL} / \mathrm{min}$; $\lambda=254 \mathrm{~nm} ; \mathrm{t}_{\mathrm{R} 1}($ major $)=10.1 \mathrm{~min} ; \mathrm{t}_{\mathrm{R} 2}$ (minor $)=9.2 \mathrm{~min}$. 

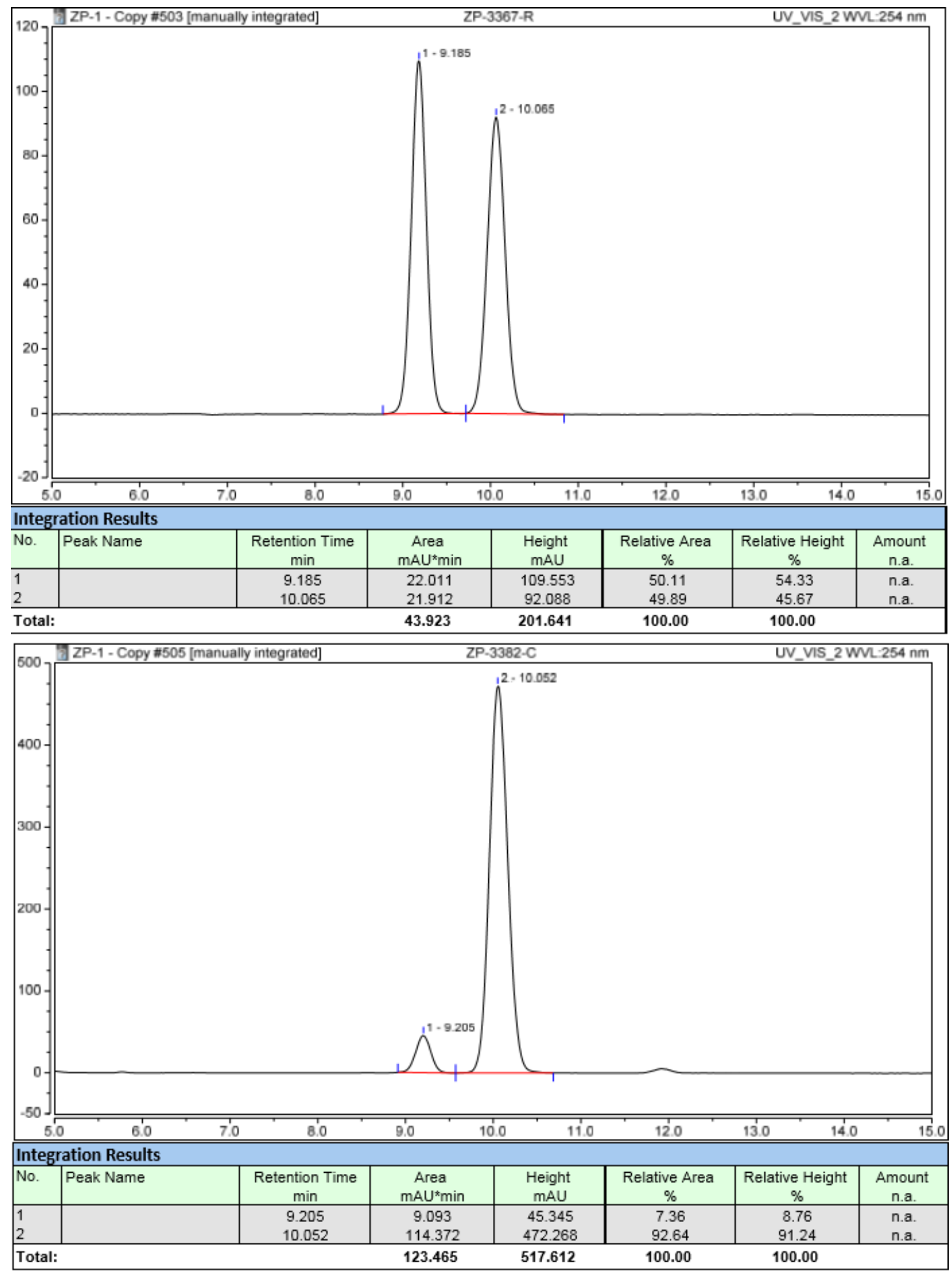<smiles>CC(C)(C)OCCCC(c1ccc(C=O)cc1)C(C(F)(F)F)C(F)(F)F</smiles>

$3 u$ 
The title compound 3u was synthesized according to General Procedure (SI 4), and it was purified by column chromatography on silica gel (65\% yield, 91:9 er, $45.6 \mathrm{mg}$, colorless oil).

${ }^{1} \mathrm{H}$ NMR (600 MHz, Chloroform- $d$ ) $\delta 10.03(\mathrm{~s}, 1 \mathrm{H}), 8.01-7.99(\mathrm{~m}, 2 \mathrm{H}), 7.90$ (d, $J=$ $8.1 \mathrm{~Hz}, 2 \mathrm{H}), 7.59-7.56(\mathrm{~m}, 1 \mathrm{H}), 7.50(\mathrm{~d}, J=7.9 \mathrm{~Hz}, 2 \mathrm{H}), 7.45(\mathrm{t}, J=7.7 \mathrm{~Hz}, 2 \mathrm{H})$, $4.29(\mathrm{t}, J=6.3 \mathrm{~Hz}, 2 \mathrm{H}), 3.46-3.39(\mathrm{~m}, 1 \mathrm{H}), 2.28-2.22(\mathrm{~m}, 1 \mathrm{H}), 2.09-2.03(\mathrm{~m}, 1 \mathrm{H})$, $1.73-1.60(\mathrm{~m}, 2 \mathrm{H}) ;[\alpha]_{\mathrm{D}}{ }^{19}=-8.281 .\left(c=0.5, \mathrm{CHCl}_{3}\right)$.

The enantiomeric excess of $\mathbf{3} \mathbf{u}$ was determined by chiral HPLC analysis.

Conditions: ChiralPak IA column; hexane $/{ }^{i} \mathrm{PrOH}=95: 5$; flow rate $=1.0 \mathrm{~mL} / \mathrm{min} ; \lambda=$ $220 \mathrm{~nm} ; \mathrm{t}_{\mathrm{R} 1}$ (major) $=12.6 \mathrm{~min} ; \mathrm{t}_{\mathrm{R} 2}$ (minor $)=13.3 \mathrm{~min}$.

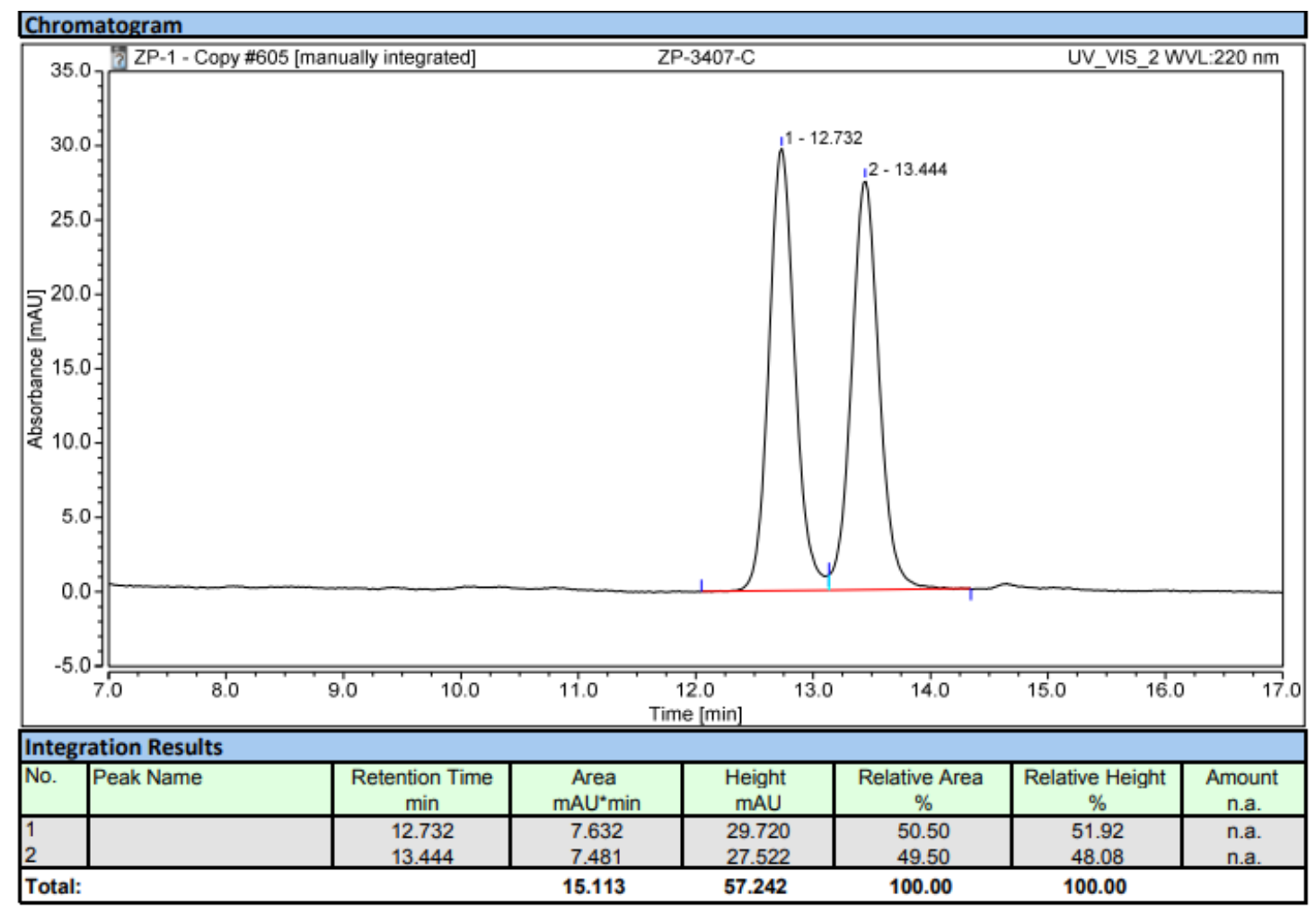




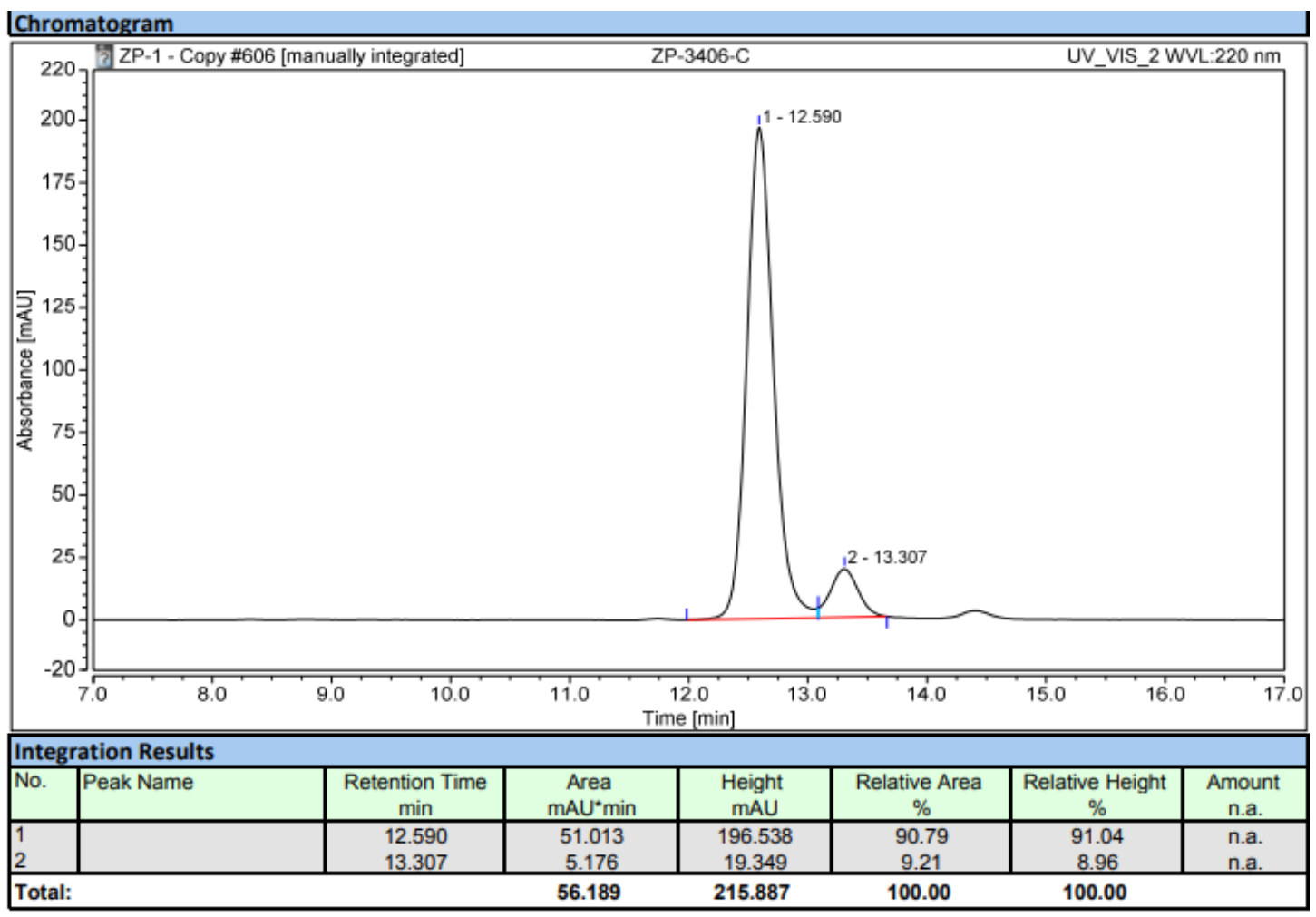<smiles>CCCCCCCCCCCCC(c1ccc(C(C)=O)cc1)C(F)(F)F</smiles>

$3 v$

The title compound $\mathbf{3 v}$ was synthesized according to General Procedure (SI 4), and it was purified by column chromatography on silica gel (80\% yield, 93:7 er, $46.0 \mathrm{mg}$, colorless oil).

${ }^{1} \mathrm{H}$ NMR (600 MHz, Chloroform- $d$ ) $\delta 7.96-7.95(\mathrm{~m}, 2 \mathrm{H}), 7.40(\mathrm{~d}, J=8.1 \mathrm{~Hz}, 2 \mathrm{H})$, $3.33-3.26(\mathrm{~m}, 1 \mathrm{H}), 2.61(\mathrm{~s}, 3 \mathrm{H}), 2.05-1.99(\mathrm{~m}, 1 \mathrm{H}), 1.91-1.84(\mathrm{~m}, 1 \mathrm{H}), 1.34-1.11$ $(\mathrm{m}, 8 \mathrm{H}), 0.84(\mathrm{t}, J=7.1 \mathrm{~Hz}, 3 \mathrm{H}) ;[\alpha]_{\mathrm{D}}{ }^{19}=-46.946 .\left(c=1.0, \mathrm{CHCl}_{3}\right)$.

The enantiomeric excess of $\mathbf{3 v}$ was determined by chiral HPLC analysis.

Conditions: ChiralPak AD-H column; hexane $/{ }^{i} \mathrm{PrOH}=95: 5$; flow rate $=0.3 \mathrm{~mL} / \mathrm{min}$; $\lambda=254 \mathrm{~nm} ; \mathrm{t}_{\mathrm{R} 1}$ (major) $=15.7 \mathrm{~min} ; \mathrm{t}_{\mathrm{R} 2}(\operatorname{minor})=16.7 \mathrm{~min}$. 

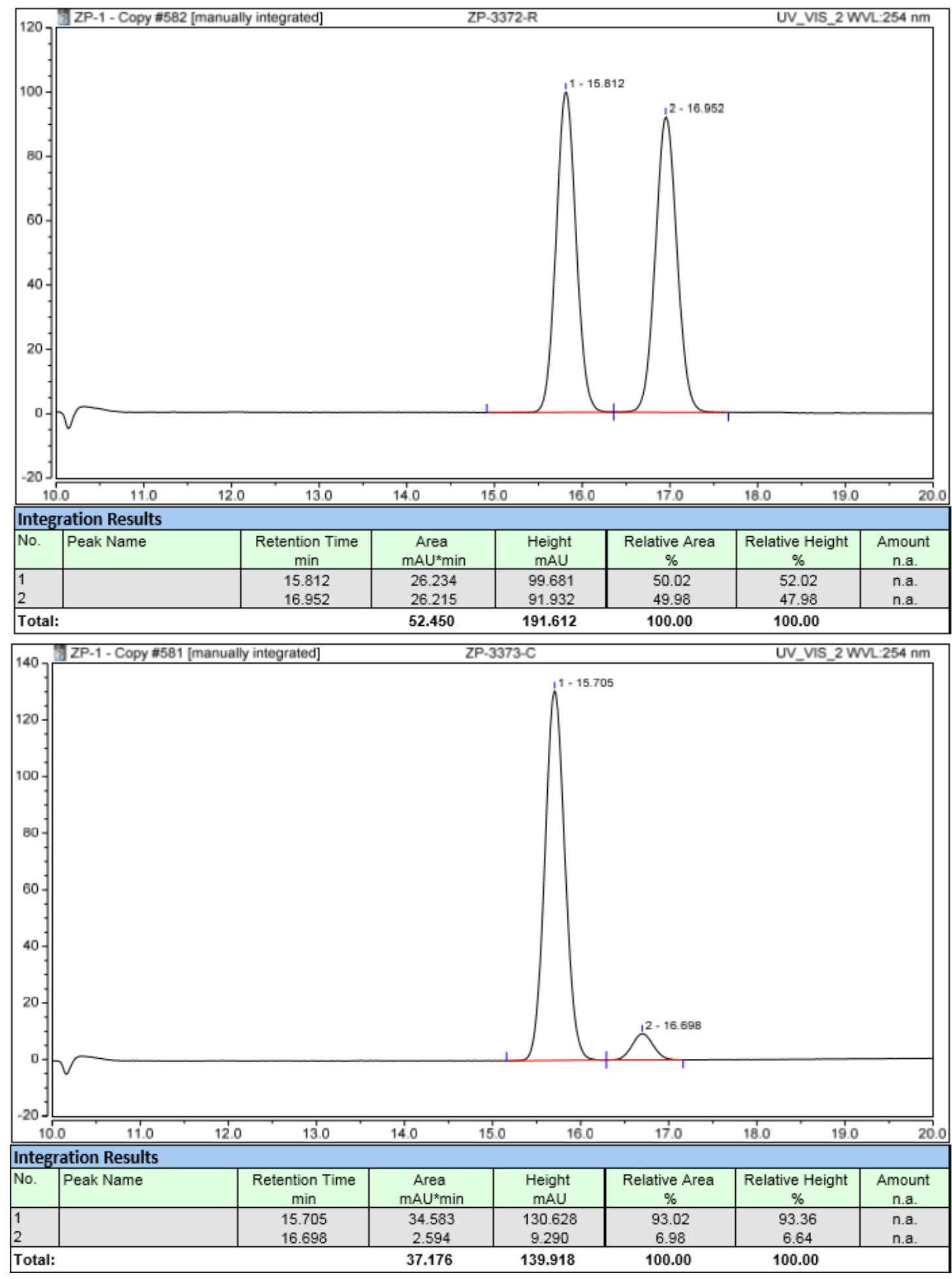<smiles>CC(=O)c1ccc([C@H](OCc2ccc(C(F)(F)F)cc2)C(F)(F)F)cc1</smiles>

$3 w$ 
The title compound 3w was synthesized according to General Procedure (SI 4), and it was purified by column chromatography on silica gel (72\% yield, 89:11 er, $54.1 \mathrm{mg}$, colorless oil).

${ }^{1} \mathrm{H}$ NMR (600 MHz, Chloroform- $d$ ) $\delta 8.03-8.01(\mathrm{~m}, 2 \mathrm{H}), 7.63(\mathrm{~d}, J=8.1 \mathrm{~Hz}, 2 \mathrm{H})$, $7.57(\mathrm{~d}, J=8.1 \mathrm{~Hz}, 2 \mathrm{H}), 7.44(\mathrm{~d}, J=8.0 \mathrm{~Hz}, 2 \mathrm{H}), 4.76-4.72(\mathrm{~m}, 1 \mathrm{H}), 4.59(\mathrm{~d}, J=$ $12.4 \mathrm{~Hz}, 1 \mathrm{H}), 2.64(\mathrm{~s}, 3 \mathrm{H}) ;{ }^{13} \mathrm{C}$ NMR $(151 \mathrm{MHz}$, Chloroform-d) $\delta 197.4,140.3$, $138.2,137.1,130.5(\mathrm{q}, J=31.7 \mathrm{~Hz}), 128.6,128.6,127.7,125.6(\mathrm{q}, J=3.8 \mathrm{~Hz})$, $124.0(\mathrm{q}, J=271.8 \mathrm{~Hz}), 123.4(\mathrm{q}, J=282.4 \mathrm{~Hz}), 78.6(\mathrm{q}, J=31.6 \mathrm{~Hz}), 71.2,26.7 ;{ }^{19} \mathrm{~F}$ NMR (565 MHz, Chloroform- $d$ ) $\delta$ - 62.6, - 76.1; HRMS (ESI) m/z: $[\mathrm{M}+\mathrm{H}]^{+}$calcd for $\mathrm{C}_{18} \mathrm{H}_{15} \mathrm{~F}_{6} \mathrm{O}_{2}{ }^{+}: 377.0971$; found: 377.0966.; $[\alpha]_{\mathrm{D}}{ }^{19}=-36.612 .\left(c=0.5, \mathrm{CHCl}_{3}\right)$.

The enantiomeric excess of $\mathbf{3 w}$ was determined by chiral HPLC analysis.

Conditions: ChiralPak IA column; hexane $/{ }^{i} \mathrm{PrOH}=90: 10$; flow rate $=1.0 \mathrm{~mL} / \mathrm{min} ; \lambda=$ $220 \mathrm{~nm} ; \mathrm{t}_{\mathrm{R} 1}$ (major) $=6.5 \mathrm{~min} ; \mathrm{t}_{\mathrm{R} 2}$ (minor) $=7.5 \mathrm{~min}$.

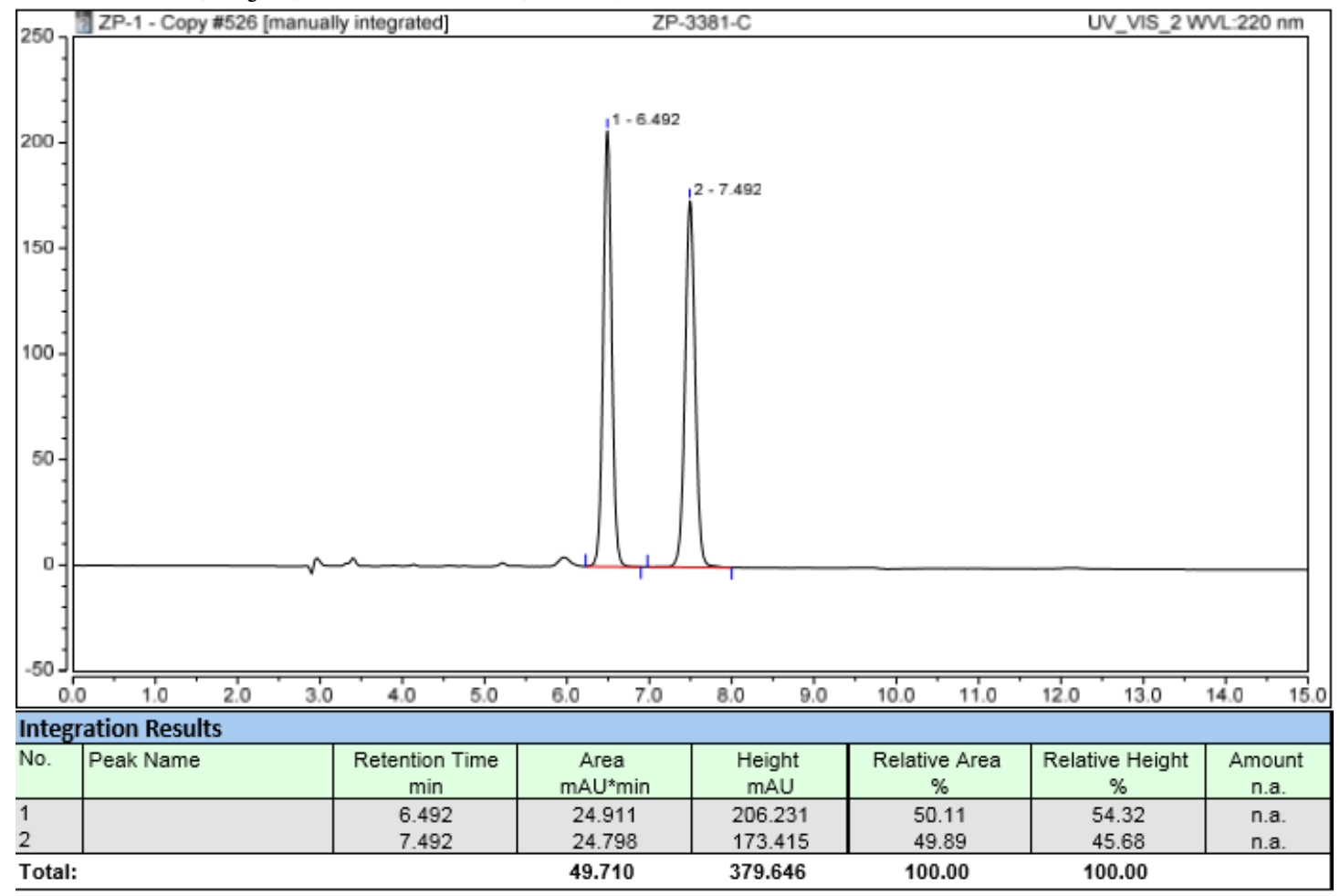




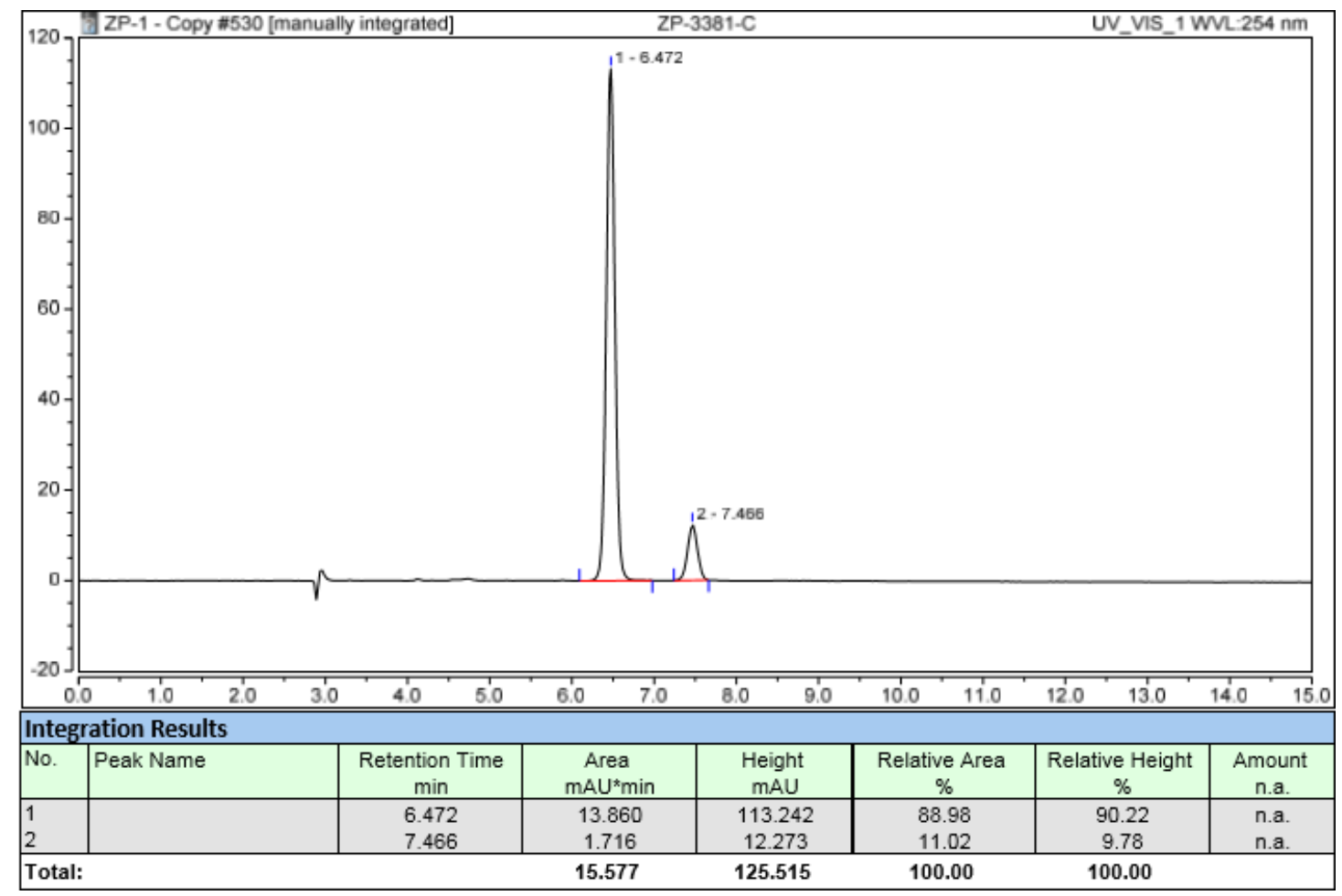<smiles>CC(=O)c1ccc(C([C@H](C)Oc2ccc(C)cc2)C(F)(F)F)cc1</smiles>

The title compound $\mathbf{3} \mathbf{x}$ was synthesized according to General Procedure (SI 4), and it was purified by column chromatography on silica gel (80\% yield, 91.5:8.5 er, 60.5 $\mathrm{mg}$, colorless oil).

${ }^{1} \mathrm{H}$ NMR (600 MHz, Chloroform- $d$ ) $\delta 7.98$ - $7.96(\mathrm{~m}, 2 \mathrm{H}), 7.93-7.91(\mathrm{~m}, 2 \mathrm{H}), 7.44$ $(\mathrm{d}, J=8.3 \mathrm{~Hz}, 2 \mathrm{H}), 6.88(\mathrm{~m}, 2 \mathrm{H}), 4.00-3.97(\mathrm{~m}, 2 \mathrm{H}), 3.45-3.38(\mathrm{~m}, 1 \mathrm{H}), 2.61(\mathrm{~s}, 3 \mathrm{H})$, $2.56(\mathrm{~s}, 3 \mathrm{H}), 2.31-2.25(\mathrm{~m}, 1 \mathrm{H}), 2.13-2.07(\mathrm{~m}, 1 \mathrm{H}), 1.77-1.64(\mathrm{~m}, 2 \mathrm{H}) ;[\alpha]_{\mathrm{D}}{ }^{19}=-$ 19.845. $\left(c=1.0, \mathrm{CHCl}_{3}\right)$.

The enantiomeric excess of $\mathbf{3 w}$ was determined by chiral HPLC analysis.

Conditions: ChiralPak IB column; hexane $/{ }^{i} \mathrm{PrOH}=90: 10$; flow rate $=1.0 \mathrm{~mL} / \mathrm{min} ; \lambda=$ $254 \mathrm{~nm} ; \mathrm{t}_{\mathrm{R} 1}$ (major) $=22.1 \mathrm{~min} ; \mathrm{t}_{\mathrm{R} 2}($ minor $)=26.5 \mathrm{~min}$. 

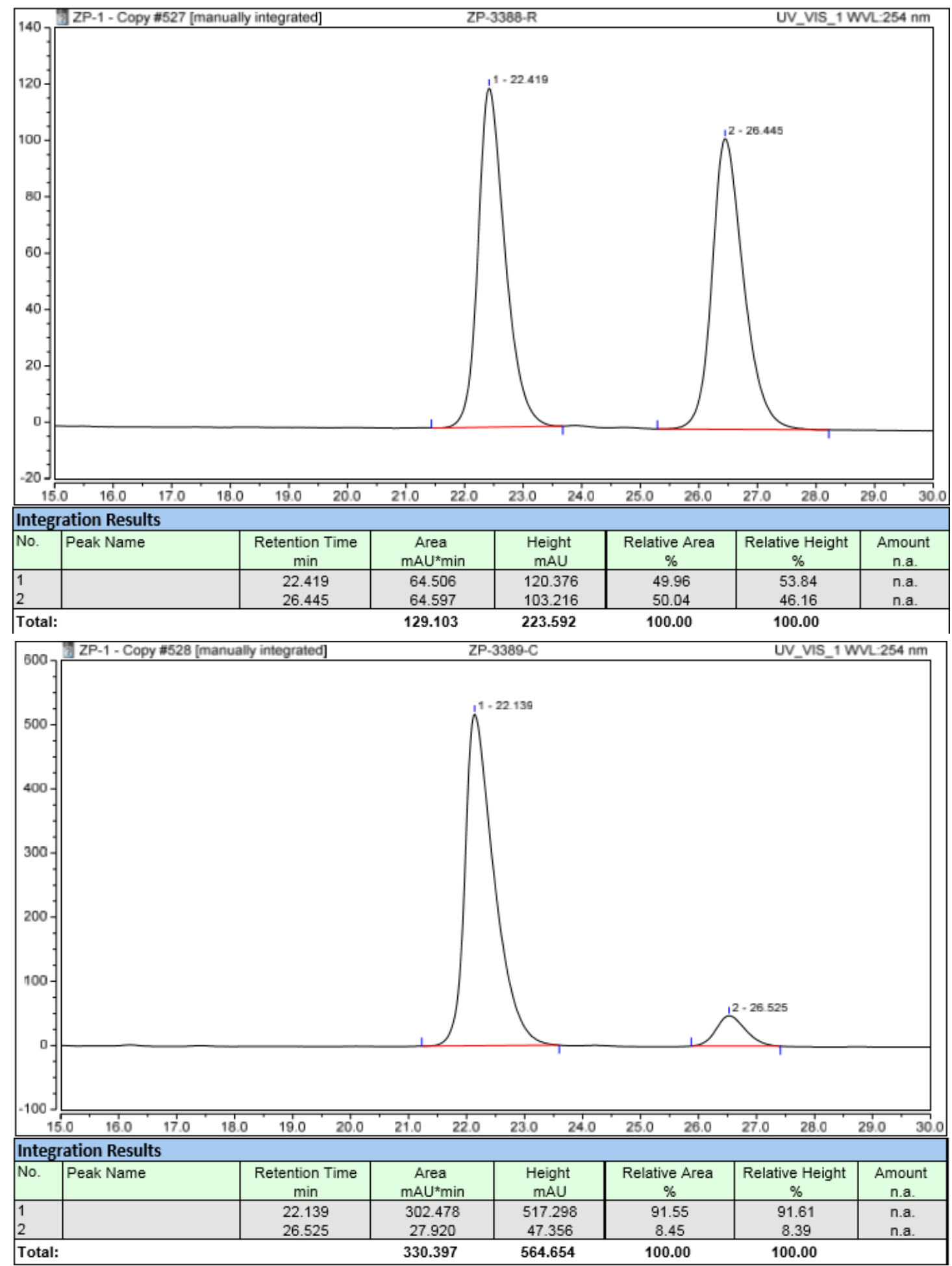<smiles>CC(=O)c1ccc([C@H]([Al])C(F)(F)F)cc1</smiles>

$3 y$ 
The title compound $\mathbf{3 y}$ was synthesized according to General Procedure (SI 4), and it was purified by column chromatography on silica gel (57\% yield, 91.5:8.5 er, 44.3 mg, colorless oil).

${ }^{1} \mathrm{H}$ NMR (600 MHz, Chloroform- $d$ ) $\delta 8.79(\mathrm{~s}, 1 \mathrm{H}), 7.97(\mathrm{~d}, J=8.3 \mathrm{~Hz}, 2 \mathrm{H}), 7.42(\mathrm{~d}, J$ $=8.1 \mathrm{~Hz}, 2 \mathrm{H}), 4.27-4.24(\mathrm{~m}, 2 \mathrm{H}), 3.42-3.35(\mathrm{~m}, 1 \mathrm{H}), 2.76(\mathrm{~s}, 3 \mathrm{H}), 2.62(\mathrm{~s}, 3 \mathrm{H})$, $2.23-2.17(\mathrm{~m}, 1 \mathrm{H}), 2.06-2.00(\mathrm{~m}, 1 \mathrm{H}), 1.71-1.58(\mathrm{~m}, 2 \mathrm{H}) ;[\alpha]_{\mathrm{D}}{ }^{19}=-20.836 .(c=$ $\left.0.5, \mathrm{CHCl}_{3}\right)$.

The enantiomeric excess of $\mathbf{3 y}$ was determined by chiral HPLC analysis.

Conditions: ChiralPak IB column; hexane $/{ }^{i} \mathrm{PrOH}=90: 10$; flow rate $=1.0 \mathrm{~mL} / \mathrm{min} ; \lambda=$ $254 \mathrm{~nm} ; \mathrm{t}_{\mathrm{R} 1}$ (major) $=18.6 \mathrm{~min} ; \mathrm{t}_{\mathrm{R} 2}($ minor $)=17.3 \mathrm{~min}$.

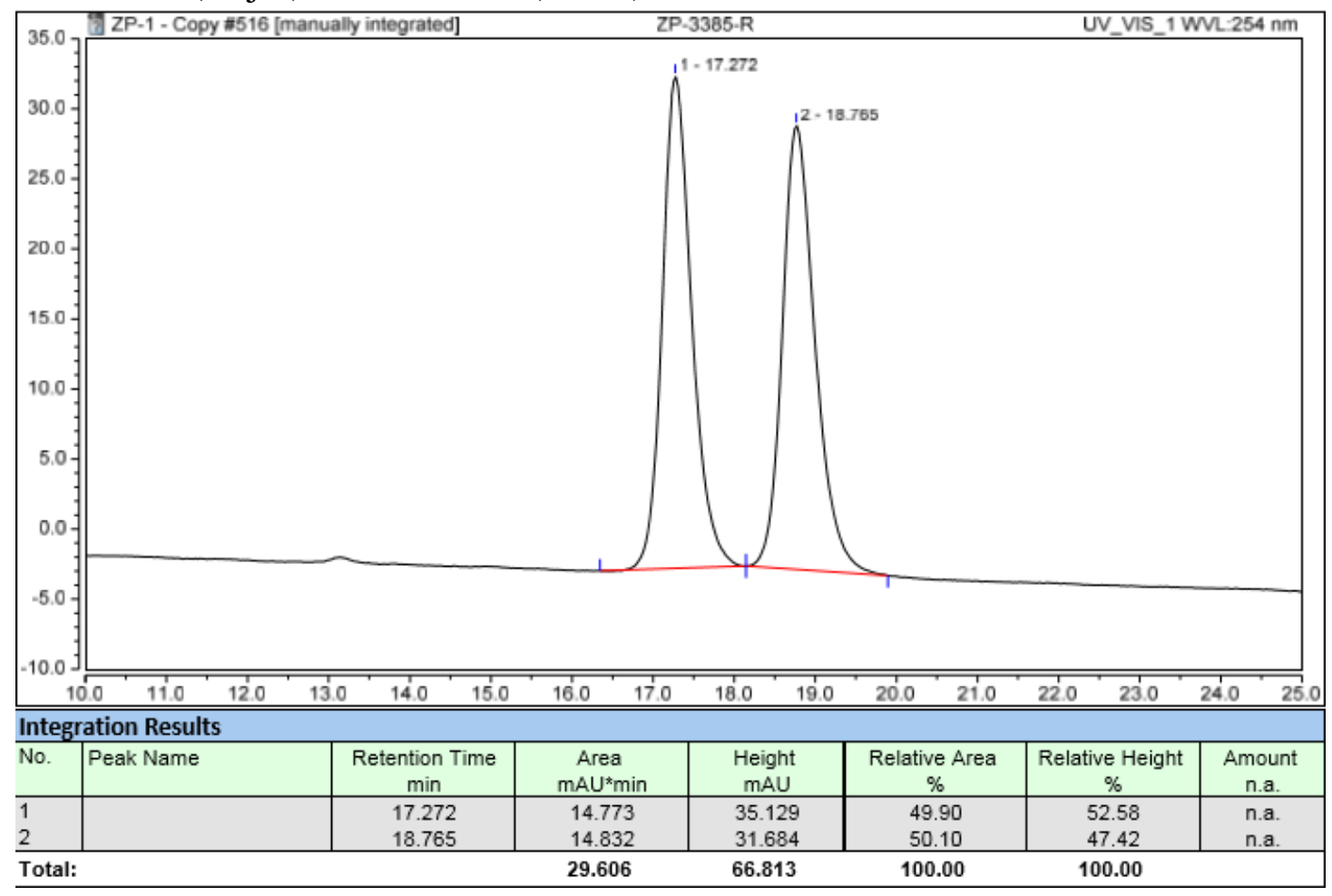




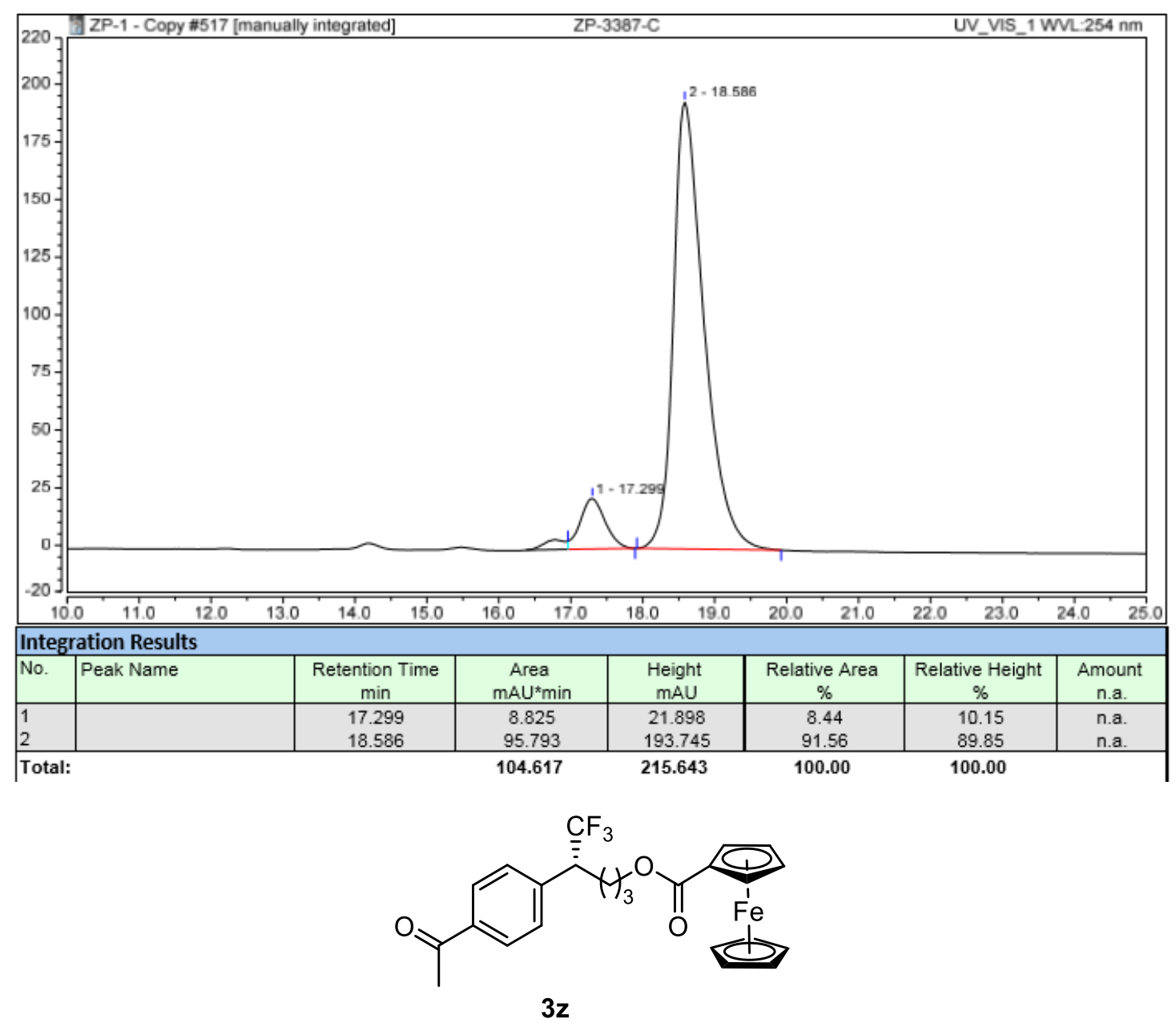

The title compound $\mathbf{3 z}$ was synthesized according to General Procedure (SI 4), and it was purified by column chromatography on silica gel (43\% yield, 91.5:8.5 er, 41.0 mg, orange oil).

${ }^{1} \mathrm{H}$ NMR $(600 \mathrm{MHz}$, Chloroform- $d) \delta 7.98(\mathrm{~d}, J=8.3 \mathrm{~Hz}, 2 \mathrm{H}), 7.44(\mathrm{~d}, J=8.1 \mathrm{~Hz}$, $2 \mathrm{H}), 4.78(\mathrm{t}, J=1.9 \mathrm{~Hz}, 2 \mathrm{H}), 4.41(\mathrm{t}, J=2.0 \mathrm{~Hz}, 2 \mathrm{H}), 4.20-4.17(\mathrm{~m}, 2 \mathrm{H}), 4.18(\mathrm{~s}$, $3 \mathrm{H}), 3.44-3.37(\mathrm{~m}, 1 \mathrm{H}), 2.26-2.20(\mathrm{~m}, 1 \mathrm{H}), 2.07-2.00(\mathrm{~m}, 1 \mathrm{H}), 1.66-1.56(\mathrm{~m}, 2 \mathrm{H})$. $[\alpha]_{\mathrm{D}}{ }^{19}=-45.601 .\left(c=0.5, \mathrm{CHCl}_{3}\right)$.

The enantiomeric excess of $\mathbf{3 z}$ was determined by chiral HPLC analysis.

Conditions: ChiralPak IA column; hexane $/{ }^{i} \mathrm{PrOH}=90: 10$; flow rate $=1.0 \mathrm{~mL} / \mathrm{min} ; \lambda=$ $254 \mathrm{~nm} ; \mathrm{t}_{\mathrm{R} 1}$ (major) $=13.4 \mathrm{~min} ; \mathrm{t}_{\mathrm{R} 2}($ minor $)=14.3 \mathrm{~min}$. 

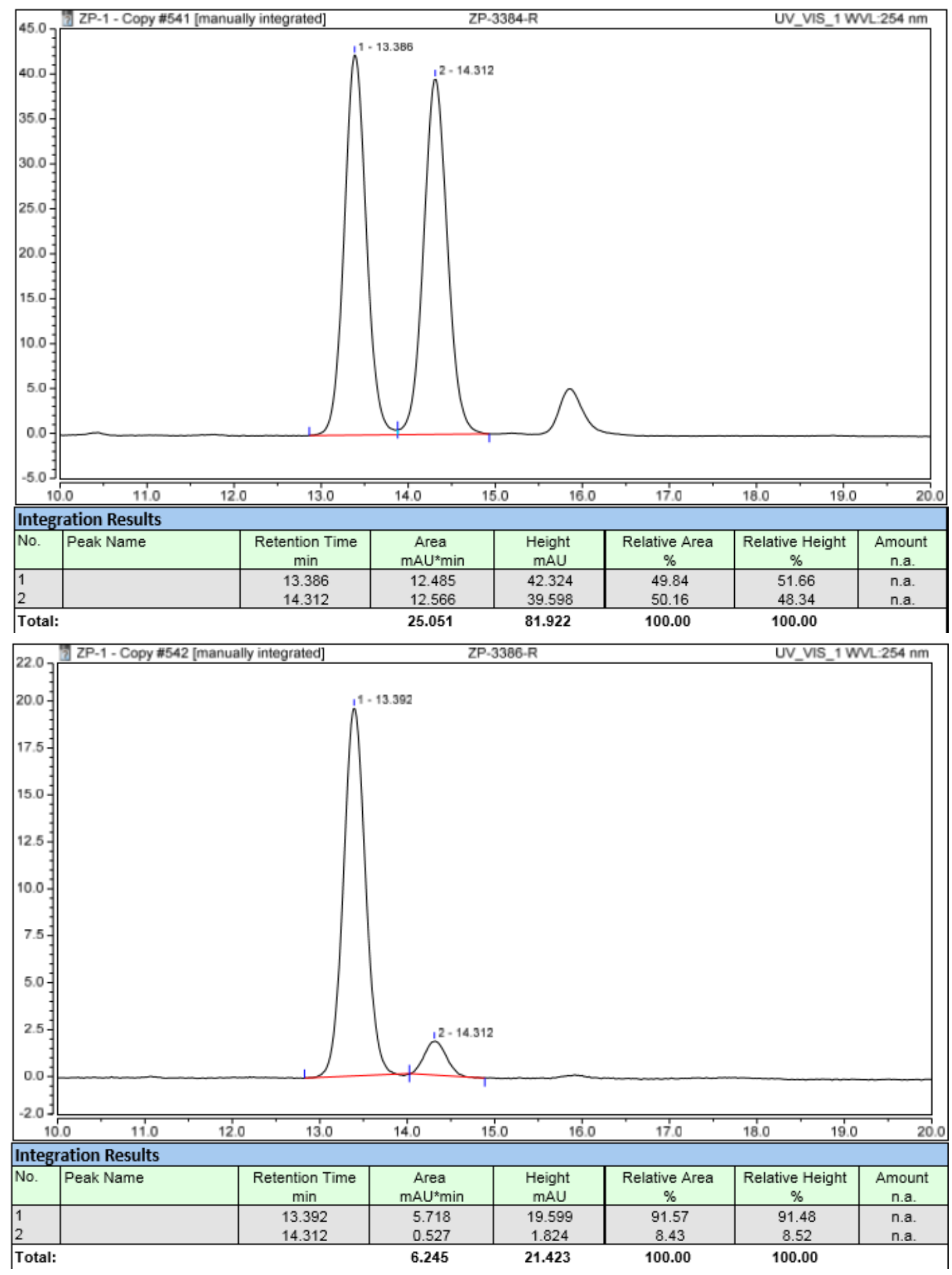<smiles>CCOC(=O)C(C)(C)Oc1ccc([C@H](CCc2ccccc2)C(F)(F)F)cc1</smiles> 
The title compound 3aa was synthesized according to General Procedure (SI 4), and it was purified by column chromatography on silica gel (74\% yield, 88:12 er, $58.3 \mathrm{mg}$, colorless oil).

${ }^{1} \mathrm{H}$ NMR (400 MHz, Chloroform- $d$ ) $\delta 7.29-7.25(\mathrm{~m}, 2 \mathrm{H}), 7.20(\mathrm{~d}, J=7.2 \mathrm{~Hz}, 1 \mathrm{H})$, $7.18-7.14(\mathrm{~m}, 2 \mathrm{H}), 7.07(\mathrm{~d}, J=7.2 \mathrm{~Hz}, 2 \mathrm{H}), 6.85(\mathrm{~d}, J=8.2 \mathrm{~Hz}, 2 \mathrm{H}), 4.24(\mathrm{q}, J=7.1$ $\mathrm{Hz}, 2 \mathrm{H}), 3.19-3.08(\mathrm{~m}, 1 \mathrm{H}), 2.60-2.53(\mathrm{~m}, 1 \mathrm{H}), 2.42-2.26(\mathrm{~m}, 2 \mathrm{H}), 2.19-2.10(\mathrm{~m}$, $1 \mathrm{H}), 1.62(\mathrm{~s}, 6 \mathrm{H}), 1.23(\mathrm{t}, J=7.1 \mathrm{~Hz}, 3 \mathrm{H}) ;[\alpha]_{\mathrm{D}}{ }^{19}=-24.114 .\left(c=0.5, \mathrm{CHCl}_{3}\right)$.

The enantiomeric excess of 3aa was determined by chiral HPLC analysis.

Conditions: ChiralPak OJ-H column; hexane $/{ }^{i} \mathrm{PrOH}=85: 15$; flow rate $=1.0 \mathrm{~mL} / \mathrm{min}$; $\lambda=220 \mathrm{~nm} ; \mathrm{t}_{\mathrm{R} 1}$ (major) $=5.6 \mathrm{~min} ; \mathrm{t}_{2}($ minor $)=5.1 \mathrm{~min}$.

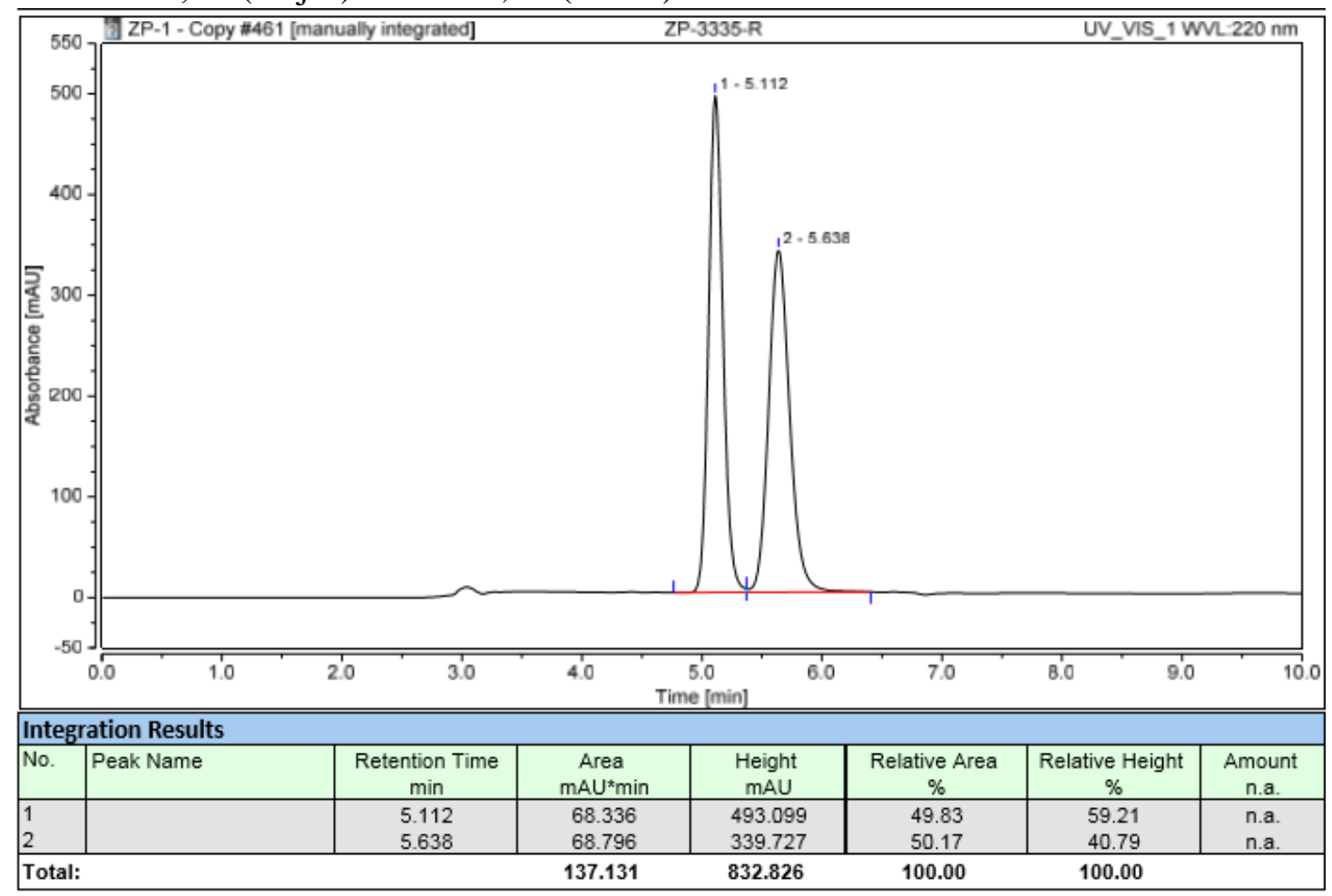




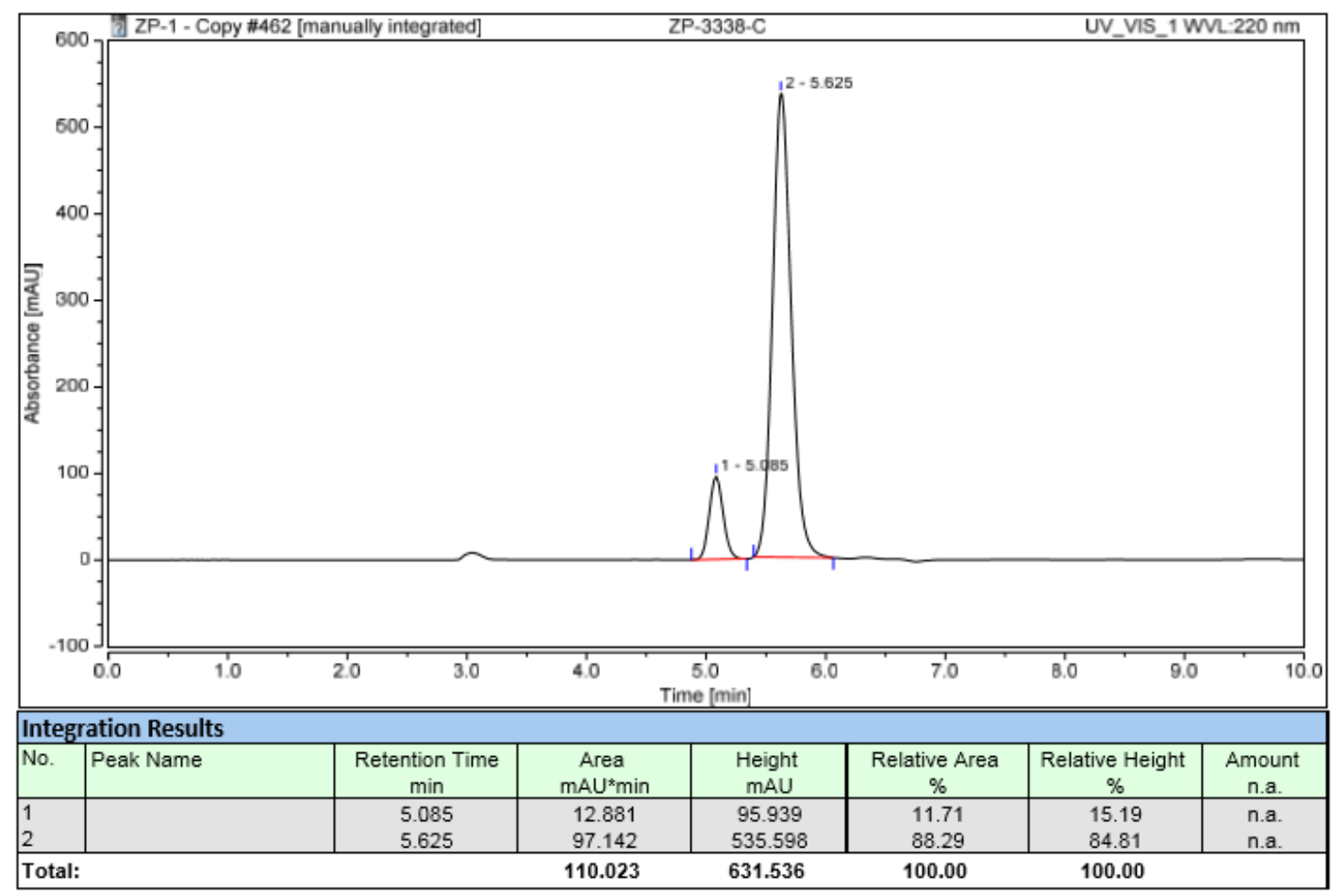<smiles>O=C1CCCN1C(=O)c1ccc([C@H](CCc2ccccc2)C(F)(F)F)cc1</smiles>

The title compound $\mathbf{3 b b}$ was synthesized according to General Procedure (SI 4), and it was purified by column chromatography on silica gel (54\% yield, 91:9 er, $40.5 \mathrm{mg}$, colorless oil).

${ }^{1} \mathrm{H}$ NMR (600 MHz, Chloroform- $d$ ) $\delta 7.65-7.63(\mathrm{~m}, 2 \mathrm{H}), 7.34(\mathrm{~d}, J=8.0 \mathrm{~Hz}, 2 \mathrm{H})$, $7.28(\mathrm{dd}, J=13.2,5.8 \mathrm{~Hz}, 2 \mathrm{H}), 7.20(\mathrm{t}, J=7.4 \mathrm{~Hz}, 1 \mathrm{H}), 7.09-7.08(\mathrm{~m}, 2 \mathrm{H}), 3.98(\mathrm{t}, J$ $=7.1 \mathrm{~Hz}, 2 \mathrm{H}), 3.30-3.24(\mathrm{~m}, 1 \mathrm{H}), 2.63(\mathrm{t}, J=8.0 \mathrm{~Hz}, 2 \mathrm{H}), 2.62-2.58(\mathrm{~m}, 1 \mathrm{H}), 2.45$ - $2.33(\mathrm{~m}, 2 \mathrm{H}), 2.25-2.20(\mathrm{~m}, 1 \mathrm{H}), 2.21-2.13(\mathrm{~m}, 2 \mathrm{H}) ;[\alpha]_{\mathrm{D}}{ }^{19}=-30.527 .(c=1.0$, $\left.\mathrm{CHCl}_{3}\right)$.

The enantiomeric excess of $\mathbf{3 b b}$ was determined by chiral HPLC analysis.

Conditions: ChiralPak IA column; hexane $/{ }^{i} \mathrm{PrOH}=95: 5$; flow rate $=0.7 \mathrm{~mL} / \mathrm{min} ; \lambda=$ $220 \mathrm{~nm} ; \mathrm{t}_{\mathrm{R} 1}($ major $)=32.4 \mathrm{~min} ; \mathrm{t}_{\mathrm{R} 2}($ minor $)=31.5 \mathrm{~min}$. 

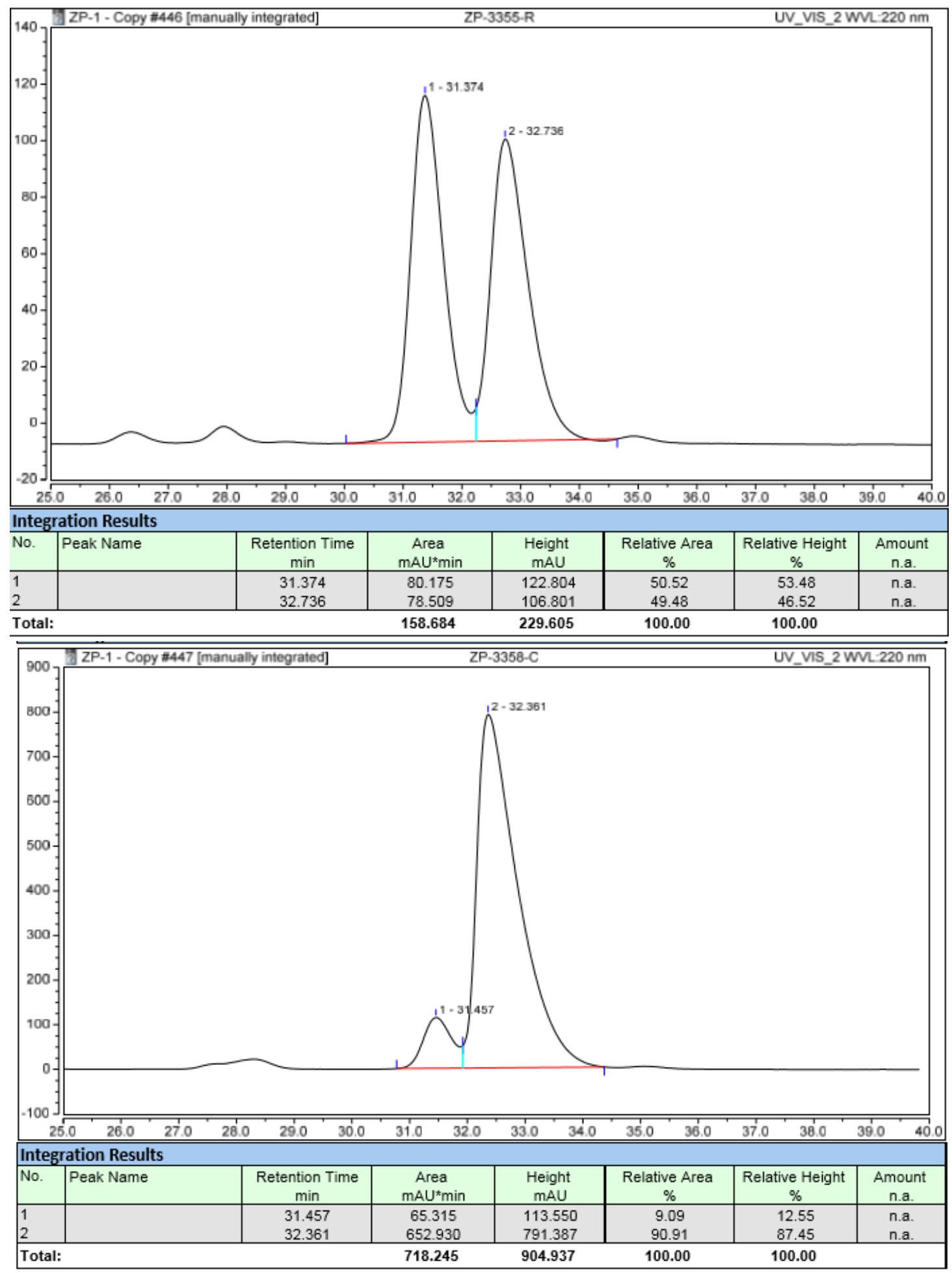<smiles>CC(C)[C@H]1CC[C@@H](C)C[C@@H]1OC(=O)c1ccc([C@@H](CCc2ccccc2)C(F)(F)F)cc1</smiles> 
The title compound 3cc was synthesized according to General Procedure (SI 4), and it was purified by column chromatography on silica gel (79\% yield, 92:8 er, $70.5 \mathrm{mg}$, colorless oil).

${ }^{1} \mathrm{H}$ NMR (600 MHz, Chloroform- $d$ ) $\delta 8.05(\mathrm{dt}, J=7.0,1.8 \mathrm{~Hz}, 1 \mathrm{H}), 7.50-7.46(\mathrm{~m}$, $2 \mathrm{H}), 7.28(\mathrm{t}, J=7.5 \mathrm{~Hz}, 2 \mathrm{H}), 7.22-7.19(\mathrm{~m}, 1 \mathrm{H}), 7.09-7.07(\mathrm{~m}, 2 \mathrm{H}), 4.96(\mathrm{td}, J=$ 10.9, $4.5 \mathrm{~Hz}, 1 \mathrm{H}), 3.32$ - $3.25(\mathrm{~m}, 1 \mathrm{H}), 2.62-2.57(\mathrm{~m}, 1 \mathrm{H}), 2.44-2.35(\mathrm{~m}, 2 \mathrm{H}), 2.29$ $2.22(\mathrm{~m}, 1 \mathrm{H}), 2.16-2.13(\mathrm{~m}, 1 \mathrm{H}), 2.00-1.94(\mathrm{~m}, 1 \mathrm{H}), 1.76-1.72(\mathrm{~m}, 2 \mathrm{H}), 1.60-$ $1.51(\mathrm{~m}, 3 \mathrm{H}), 1.19-1.08(\mathrm{~m}, 2 \mathrm{H}), 0.95-0.93(\mathrm{~m}, 6 \mathrm{H}), 0.92-0.90(\mathrm{~m}, 1 \mathrm{H}), 0.82$ (d, $J$ $=6.9 \mathrm{~Hz}, 3 \mathrm{H}) ;{ }^{13} \mathrm{C}$ NMR $(151 \mathrm{MHz}$, Chloroform- $d$ ) $\delta 165.7,140.3,133.2,131.4$, $130.6,129.5,128.8,128.5,128.4,128.1(\mathrm{q}, J=231.0 \mathrm{~Hz}), 126.3,75.1,48.9$ (q, $J$ $=25.7 \mathrm{~Hz}), 47.2,40.9,34.3,32.4,31.4(\mathrm{q}, J=2.6 \mathrm{~Hz}), 30.0,26.6,23.7,20.0$, $20.8,16.6$; ${ }^{19} \mathrm{~F}$ NMR (565 MHz, Chloroform- $d$ ) $\delta-69.6$; HRMS (ESI) m/z: $[\mathrm{M}+\mathrm{H}]^{+}$calcd for $\mathrm{C}_{27} \mathrm{H}_{34} \mathrm{~F}_{3} \mathrm{O}_{2}{ }^{+}: 447.2505$; found: 447.2506.; $[\alpha]_{\mathrm{D}}{ }^{19}=-42.683$. $(c=$ 2.0, $\mathrm{CHCl}_{3}$ ).

The enantiomeric excess of 3cc was determined by chiral HPLC analysis.

Conditions: ChiralPak AD-H column; hexane $/ \mathrm{PrOH}=90: 10$; flow rate $=0.7 \mathrm{~mL} / \mathrm{min}$; $\lambda=220 \mathrm{~nm} ; \mathrm{t}_{\mathrm{R} 1}$ (major) $=4.7 \mathrm{~min} ; \mathrm{t}_{\mathrm{R} 2}($ minor $)=5.0 \mathrm{~min}$.

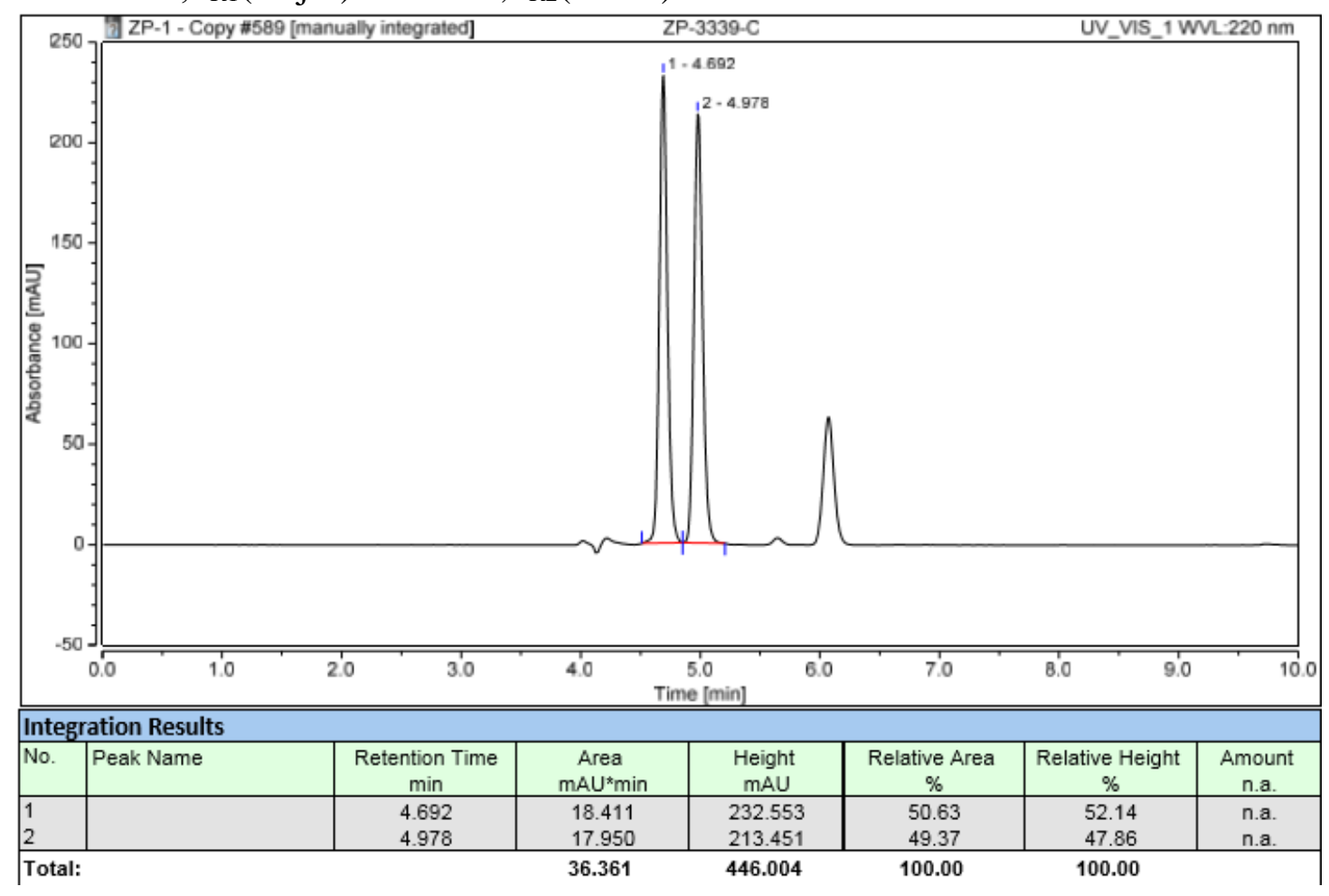




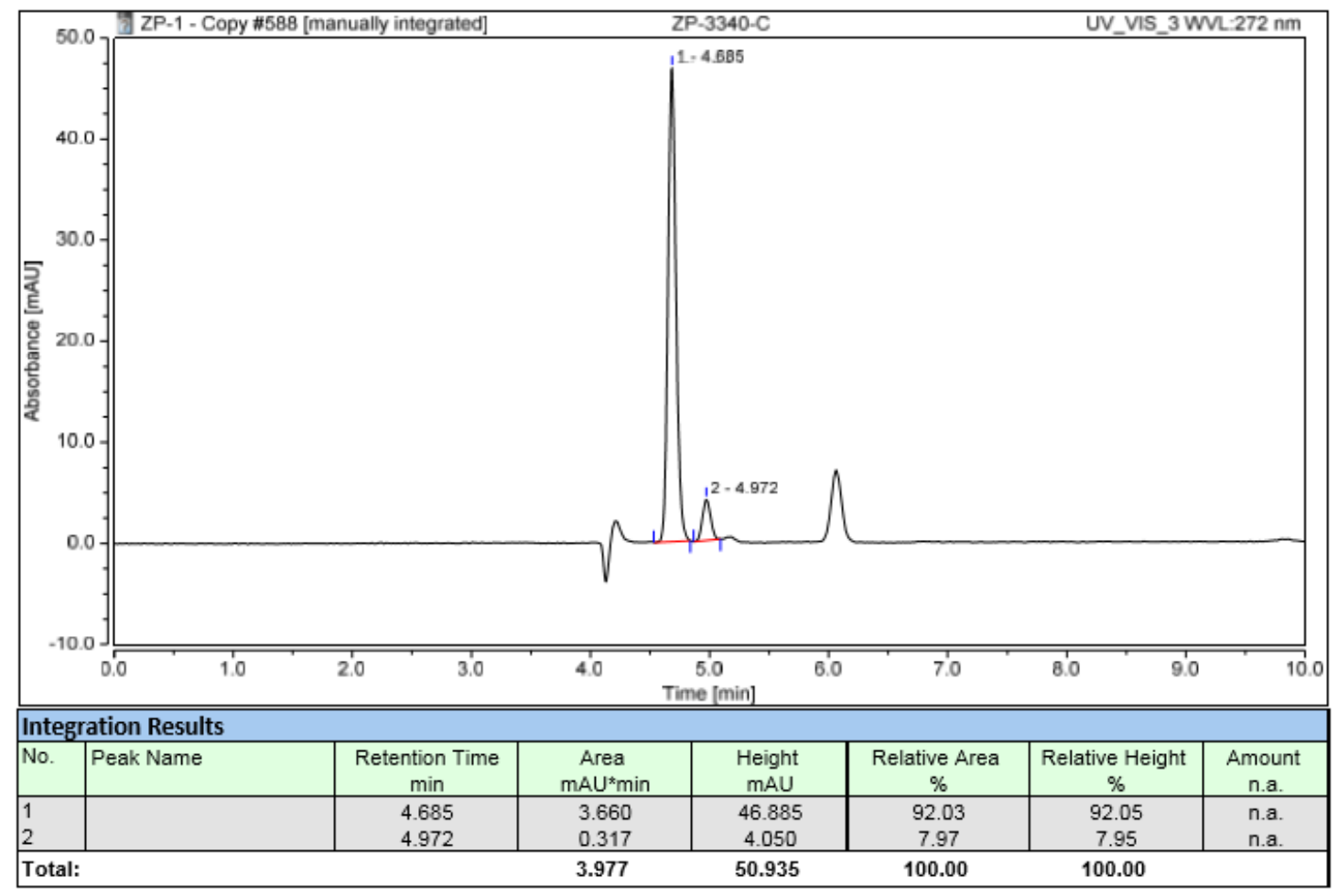<smiles>CC(=O)c1ccc(C(NOc2ccc3c(c2)CC[C@@H]2[C@H]3CC[C@]3(C)C(=O)CC[C@H]23)C(F)(F)F)cc1</smiles>

The title compound 3dd was synthesized according to General Procedure (SI 4), and it was purified by column chromatography on silica gel (66\% yield, 92:8 er, $67.6 \mathrm{mg}$, colorless oil).

${ }^{1} \mathrm{H}$ NMR (600 MHz, Chloroform- $d$ ) $\delta 7.96(\mathrm{~d}, J=8.3 \mathrm{~Hz}, 2 \mathrm{H}), 7.43(\mathrm{~d}, J=8.1 \mathrm{~Hz}$, 2H), $7.19(\mathrm{~d}, J=8.6 \mathrm{~Hz}, 1 \mathrm{H}), 6.67(\mathrm{dd}, J=8.6,2.7 \mathrm{~Hz}, 1 \mathrm{H}), 6.59(\mathrm{~s}, 1 \mathrm{H}), 3.90-3.87$ $(\mathrm{m}, 2 \mathrm{H}), 3.45-3.38(\mathrm{~m}, 1 \mathrm{H}), 2.88-2.87(\mathrm{~m}, 2 \mathrm{H}), 2.61(\mathrm{~s}, 3 \mathrm{H}), 2.51(\mathrm{q}, J=9 \mathrm{~Hz}, 1 \mathrm{H})$, $2.40-2.37(\mathrm{~m}, 1 \mathrm{H}), 2.29-2.23(\mathrm{~m}, 2 \mathrm{H}), 2.17-2.10(\mathrm{~m}, 1 \mathrm{H}), 2.10-2.03(\mathrm{~m}, 2 \mathrm{H})$, $2.02-1.98(\mathrm{~m}, 1 \mathrm{H}), 1.96-1.94(\mathrm{~m}, 1 \mathrm{H}), 1.70-1.55(\mathrm{~m}, 4 \mathrm{H}), 1.54-1.48(\mathrm{~m}, 3 \mathrm{H})$, $1.47-1.40(\mathrm{~m}, 1 \mathrm{H}), 0.91(\mathrm{~s}, 3 \mathrm{H}) ;{ }^{13} \mathrm{C}$ NMR (151 MHz, Chloroform-d) $\delta 197.5$, $156.7,139.8,137.8,137.0,132.2,129.4,128.7,126.5$ (q, $J=280.9 \mathrm{~Hz}), 126.3$, $114.5,114.4,112.0,66.9,50.4,49.8$ (q, $J=27.2 \mathrm{~Hz}), 48.0$, $44.0,38.3$, 35.9 , $31.6,29.6,26.6,26.5,26.5,25.9,25.5,21.6,13.8 ;{ }^{19} \mathrm{~F}$ NMR $(565 \mathrm{MHz}$, Chloroform- $d$ ) $\delta-69.5$; HRMS (ESI) $\mathrm{m} / \mathrm{z}$ : $[\mathrm{M}+\mathrm{H}]^{+}$calcd for $\mathrm{C}_{31} \mathrm{H}_{36} \mathrm{~F}_{3} \mathrm{O}_{3}{ }^{+}$: 513.2611; found: 513.2600.; $[\alpha]_{\mathrm{D}}{ }^{19}=58.996 .\left(c=1.0, \mathrm{CHCl}_{3}\right)$.

The enantiomeric excess of 3dd was determined by chiral HPLC analysis.

Conditions: ChiralPak IB column; hexane $/{ }^{i} \mathrm{PrOH}=90: 10$; flow rate $=1.0 \mathrm{~mL} / \mathrm{min} ; \lambda=$ $220 \mathrm{~nm} ; \mathrm{t}_{\mathrm{R} 1}($ major $)=21.0 \mathrm{~min} ; \mathrm{t}_{\mathrm{R} 2}($ minor $)=23.2 \mathrm{~min}$. 

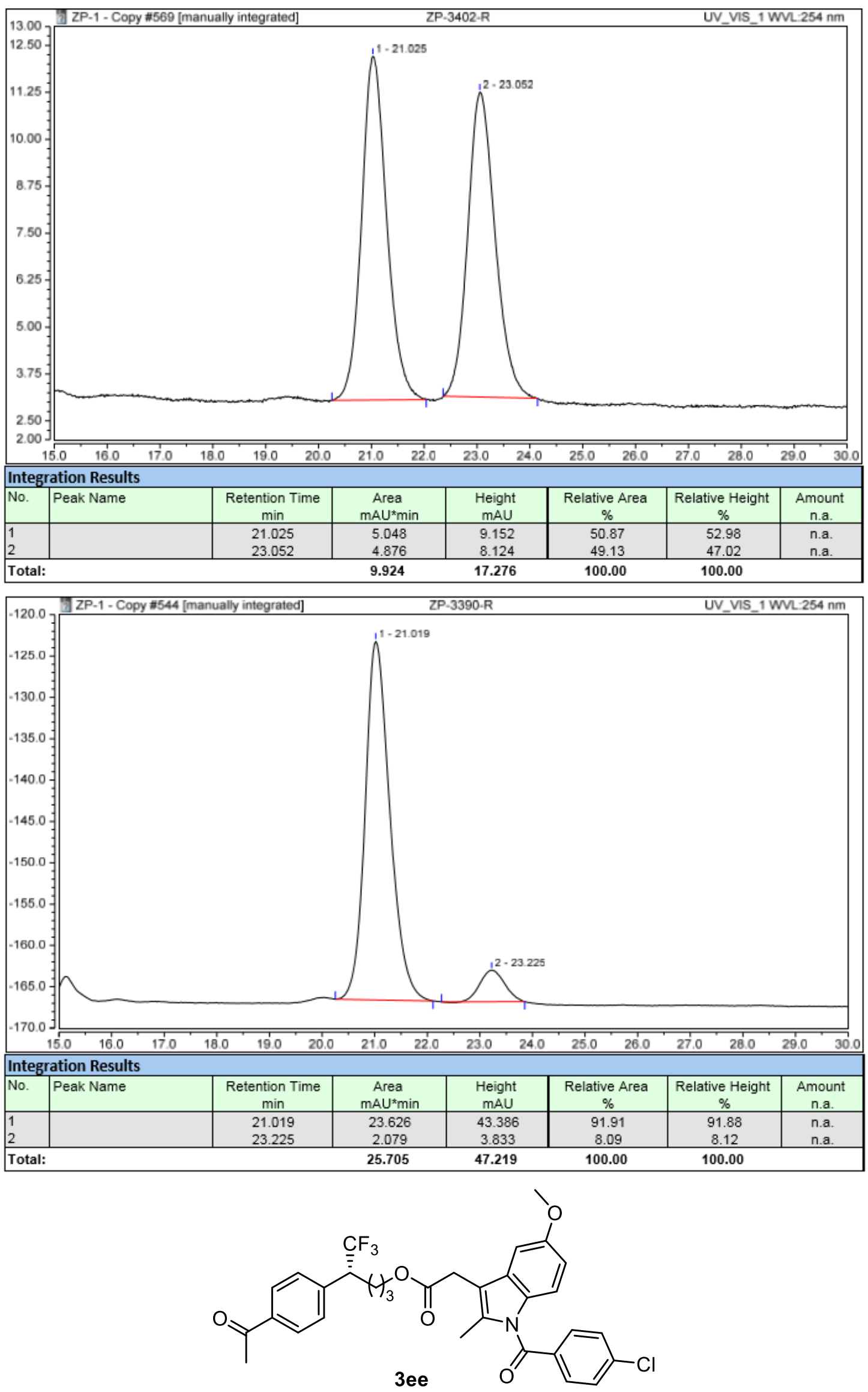
The title compound 3ee was synthesized according to General Procedure (SI 4), and it was purified by column chromatography on silica gel (54\% yield, 90:10 er, $65.2 \mathrm{mg}$, colorless oil).

${ }^{1} \mathrm{H}$ NMR (600 MHz, Chloroform- $d$ ) $\delta 7.91$ - 7.89 (m, 2H), 7.66 - 7.64 (m, 2H), 7.48 $7.46(\mathrm{~m}, 2 \mathrm{H}), 7.27-7.25(\mathrm{~m}, 2 \mathrm{H}), 6.95(\mathrm{~d}, J=2.5 \mathrm{~Hz}, 1 \mathrm{H}), 6.88(\mathrm{~d}, J=9.0 \mathrm{~Hz}, 1 \mathrm{H})$, $6.69(\mathrm{dd}, J=9.0,2.6 \mathrm{~Hz}, 1 \mathrm{H}), 4.08-4.06(\mathrm{~m}, 2 \mathrm{H}), 3.82(\mathrm{~s}, 3 \mathrm{H}), 3.66(\mathrm{~s}, 2 \mathrm{H}), 3.29-$ $3.22(\mathrm{~m}, 1 \mathrm{H}), 2.60(\mathrm{~s}, 3 \mathrm{H}), 2.38(\mathrm{~s}, 3 \mathrm{H}), 2.05-1.98(\mathrm{~m}, 1 \mathrm{H}), 1.88-1.82(\mathrm{~m}, 1 \mathrm{H}), 1.53$ - $1.40(\mathrm{~m}, 2 \mathrm{H}) ;{ }^{13} \mathrm{C}$ NMR $(151 \mathrm{MHz}$, Chloroform- $d$ ) $\delta 197.4,170.7,168.2,156.0$, $137.0,135.9,133.8,131.1,130.8,130.5,129.1,129.1,128.7,124.4$ (q, $J=280.9$ $\mathrm{Hz}), 115.0,112.4,111.5,101.3,64.0,55.6,49.6$ (q, $J=33.2 \mathrm{~Hz}), 30.4,26.6$, $25.9,25.1,13.3 ;{ }^{19} \mathrm{~F}$ NMR (565 MHz, Chloroform- $d$ ) $\delta-69.6$; HRMS (ESI) m/z: $[\mathrm{M}+\mathrm{Na}]^{+}$calcd for $\mathrm{C}_{32} \mathrm{H}_{29} \mathrm{ClF}_{3} \mathrm{NNaO}_{5}{ }^{+}$: 622.1579; found: 622.1774.; $[\alpha]_{\mathrm{D}}{ }^{19}=-$ 32.999. ( $\left.c=0.5, \mathrm{CHCl}_{3}\right)$.

The enantiomeric excess of 3ee was determined by chiral HPLC analysis.

Conditions: ChiralPak IB column; hexane $/{ }^{i} \mathrm{PrOH}=70: 30$; flow rate $=0.6 \mathrm{~mL} / \mathrm{min} ; \lambda=$ $272 \mathrm{~nm} ; \mathrm{t}_{\mathrm{R} 1}$ (major) $=26.0 \mathrm{~min} ; \mathrm{t}_{\mathrm{R} 2}$ (minor $)=20.9 \mathrm{~min}$.

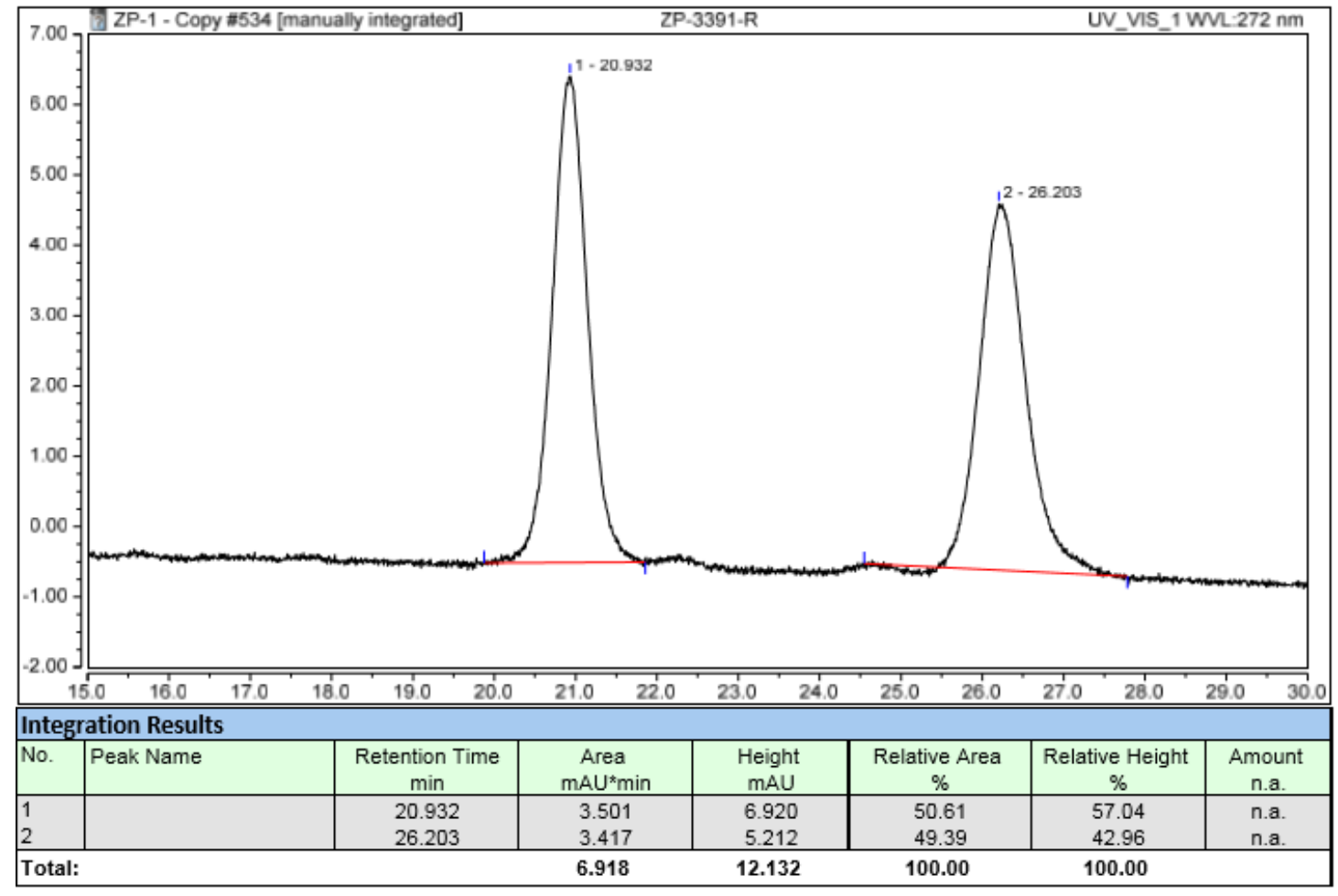




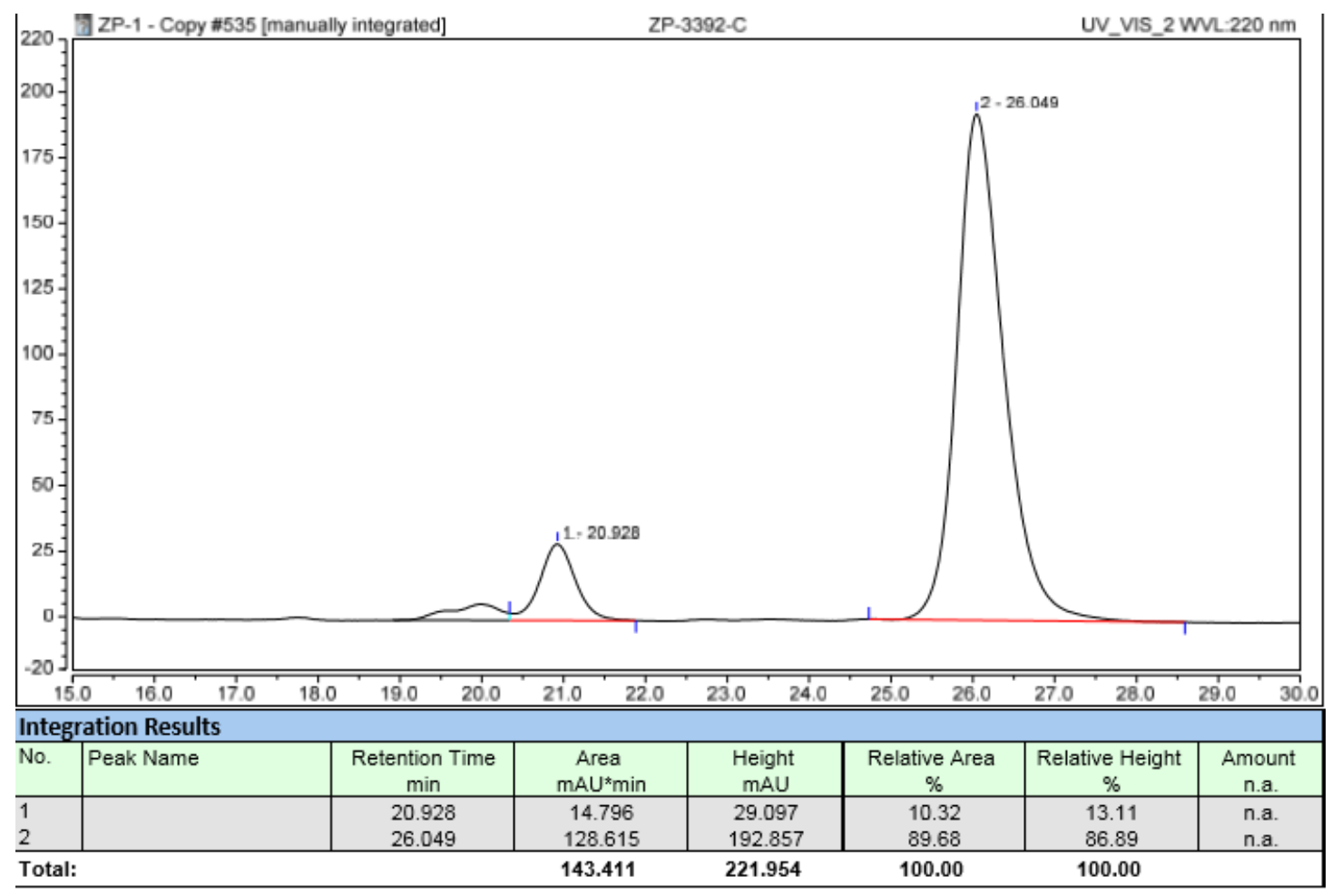<smiles>COc1ccc2c(c1)c(CC(=O)Oc1cccc([C@H](CCc3ccccc3)C(F)(F)F)c1)c(C)n2C(=O)c1ccc(Cl)cc1</smiles>

The title compound 3ff was synthesized according to General Procedure (SI 4), and it was purified by column chromatography on silica gel (46\% yield, 92:8 er, $56.5 \mathrm{mg}$, colorless oil).

${ }^{1} \mathrm{H}$ NMR (600 MHz, Chloroform- $d$ ) $\delta 7.68(\mathrm{~d}, J=8.5 \mathrm{~Hz}, 2 \mathrm{H}), 7.48(\mathrm{~d}, J=8.5 \mathrm{~Hz}$, 2H), $7.38(\mathrm{t}, J=7.9 \mathrm{~Hz}, 1 \mathrm{H}), 7.27-7.24(\mathrm{~m}, 2 \mathrm{H}), 7.20-7.17(\mathrm{~m}, 1 \mathrm{H}), 7.15(\mathrm{~d}, J=7.7$ $\mathrm{Hz}, 1 \mathrm{H}), 7.10-7.06(\mathrm{~m}, 4 \mathrm{H}), 7.02(\mathrm{~s}, 1 \mathrm{H}), 6.90(\mathrm{~d}, J=9.0 \mathrm{~Hz}, 1 \mathrm{H}), 6.71$ (dd, $J=9.0$, $2.5 \mathrm{~Hz}, 1 \mathrm{H}), 3.93(\mathrm{~s}, 2 \mathrm{H}), 3.84(\mathrm{~s}, 3 \mathrm{H}), 3.23-3.16(\mathrm{~m}, 1 \mathrm{H}), 2.61-2.57(\mathrm{~m}, 1 \mathrm{H}), 2.47$ $(\mathrm{s}, 3 \mathrm{H}), 2.43-2.38(\mathrm{~m}, 1 \mathrm{H}), 2.35-2.30(\mathrm{~m}, 1 \mathrm{H}), 2.20-2.13(\mathrm{~m}, 1 \mathrm{H}) ;{ }^{13} \mathrm{C}$ NMR $(151$ MHz, Chloroform- $d$ ) $\delta 169.1,168.3$, 156.1 , 150.9 , 140.3 , 139.4 , 136.3 , 133.8 , $131.2,130.8,130.5,129.7,129.2,128.5,128.4,126.7,126.6(\mathrm{q}, J=282.4 \mathrm{~Hz})$, $126.3,122.2,121.3,115.0,111.8,111.8,101.2,55.7,48.8(\mathrm{q}, J=25.7 \mathrm{~Hz}), 32.4$, 30.6 , 30.1 , 13.5; ${ }^{19} \mathrm{~F}$ NMR (565 MHz, Chloroform- $d$ ) $\delta-69.6$; HRMS (ESI) m/z: $[\mathrm{M}+\mathrm{H}]^{+}$calcd for $\mathrm{C}_{35} \mathrm{H}_{30} \mathrm{ClF}_{3} \mathrm{NO}_{4}{ }^{+}: 620.1810$; found: 620.1795.; $[\alpha]_{\mathrm{D}}{ }^{19}=-44.800 .(c$ $\left.=0.5, \mathrm{CHCl}_{3}\right)$.

The enantiomeric excess of $\mathbf{3 f f}$ was determined by chiral HPLC analysis.

Conditions: ChiralPak Ia column; hexane $/{ }^{i} \mathrm{PrOH}=70: 30$; flow rate $=0.5 \mathrm{~mL} / \mathrm{min} ; \lambda=$ $272 \mathrm{~nm} ; \mathrm{t}_{\mathrm{R} 1}($ major $)=13.5 \mathrm{~min} ; \mathrm{t}_{\mathrm{R} 2}($ minor $)=16.1 \mathrm{~min}$. 

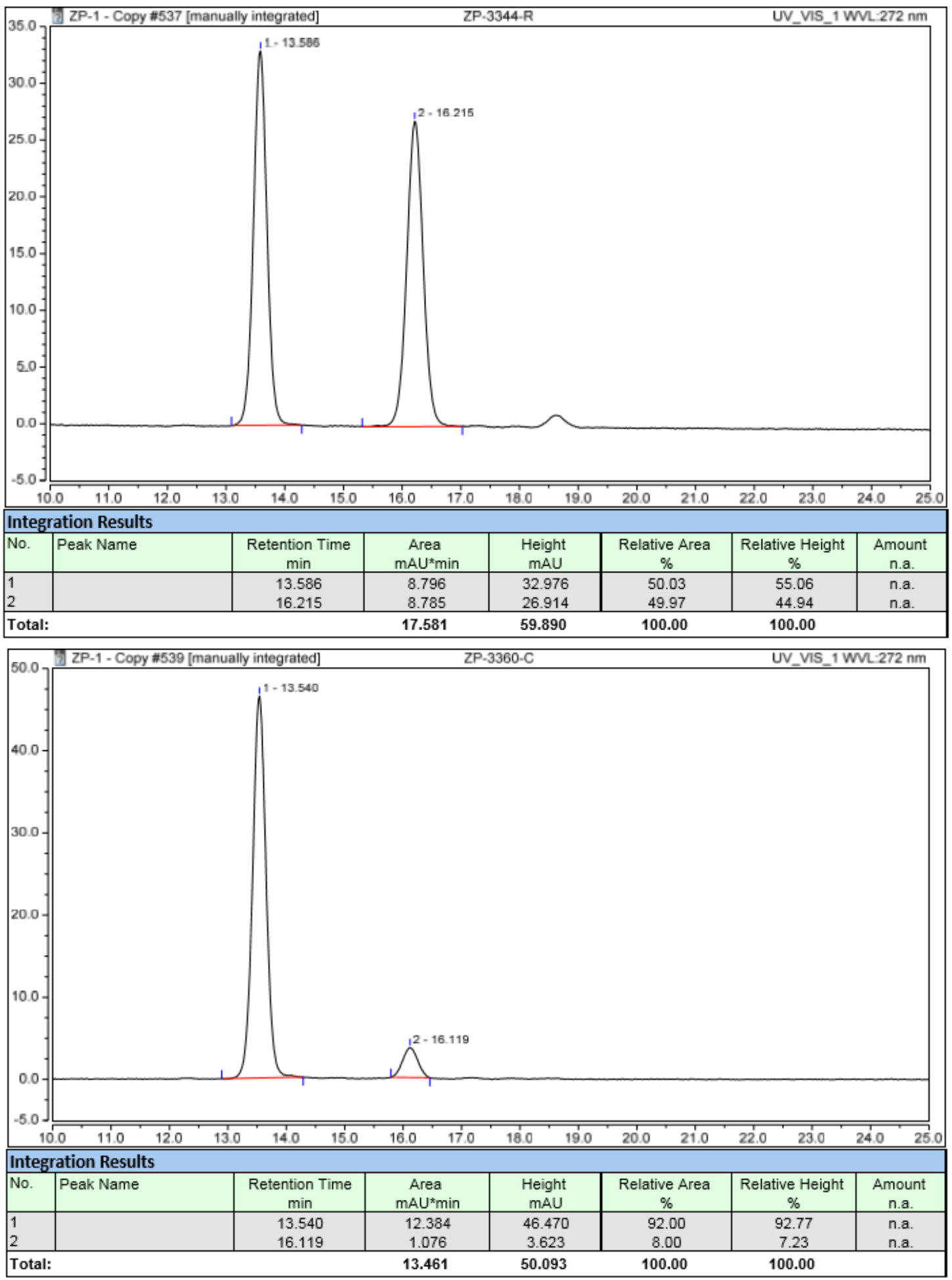<smiles>COc1ccc2c(c1)c(CC(=O)Oc1cc([C@H](CCc3ccccc3)C(F)(F)F)ccc1C(C)(C)C)c(C)n2C(=O)c1ccc(Cl)cc1</smiles> 
The title compound 3gg was synthesized according to General Procedure (SI 4), and it was purified by column chromatography on silica gel (62\% yield, 91:9 er, $84.0 \mathrm{mg}$, colorless oil).

${ }^{1} \mathrm{H}$ NMR (600 MHz, Chloroform- $d$ ) $\delta 8.03(\mathrm{~d}, J=8.1 \mathrm{~Hz}, 1 \mathrm{H}), 7.69(\mathrm{~d}, J=8.5 \mathrm{~Hz}$, $2 \mathrm{H}), 7.47(\mathrm{~d}, J=8.5 \mathrm{~Hz}, 2 \mathrm{H}), 7.26-7.22(\mathrm{~m}, 3 \mathrm{H}), 7.20-7.17(\mathrm{~m}, 1 \mathrm{H}), 7.15(\mathrm{~d}, J=$ $2.5 \mathrm{~Hz}, 1 \mathrm{H}), 7.05(\mathrm{dd}, J=7.2,1.7 \mathrm{~Hz}, 2 \mathrm{H}), 7.01(\mathrm{~d}, J=1.7 \mathrm{~Hz}, 1 \mathrm{H}), 6.91(\mathrm{~d}, J=9.0$ $\mathrm{Hz}, 1 \mathrm{H}), 6.70(\mathrm{dd}, J=9.0,2.6 \mathrm{~Hz}, 1 \mathrm{H}), 4.04(\mathrm{~s}, 2 \mathrm{H}), 3.85(\mathrm{~s}, 3 \mathrm{H}), 3.82(\mathrm{~s}, 3 \mathrm{H}), 3.27$ $3.20(\mathrm{~m}, 1 \mathrm{H}), 2.61-2.56(\mathrm{~m}, 1 \mathrm{H}), 2.47(\mathrm{~s}, 3 \mathrm{H}), 2.41-2.33(\mathrm{~m}, 2 \mathrm{H}), 2.23-2.11(\mathrm{~m}$, $1 \mathrm{H}) ;{ }^{13} \mathrm{C}$ NMR (151 MHz, Chloroform- $d$ ) $\delta 169.3,168.3,156.1,150.9,140.9$, $139.8,139.3,136.4,133.9,132.0,131.2,130.8,130.8,129.1,128.6,128.4$, $126.8,126.4,126.3(\mathrm{q}, J=276.3 \mathrm{~Hz}), 124.6,123.0,114.94,111.9,111.8,101.4$, 55.7 , $52.2,48.7$ (q, $J=27.2 \mathrm{~Hz}), 32.2,30.1,29.9,13.5 . ;{ }^{19} \mathrm{~F}$ NMR $(565 \mathrm{MHz}$, Chloroform- $d$ ) $\delta$ - 69.2; HRMS (ESI) m/z: $[\mathrm{M}+\mathrm{H}]^{+}$calcd for $\mathrm{C}_{37} \mathrm{H}_{32} \mathrm{ClF}_{3} \mathrm{NO}_{6}{ }^{+}$: 678.1865; found: 678.1870; $[\alpha]_{\mathrm{D}}{ }^{19}=-24.489 .\left(c=0.5, \mathrm{CHCl}_{3}\right)$.

The enantiomeric excess of $\mathbf{3 g g}$ was determined by chiral HPLC analysis.

Conditions: ChiralPak IA column; hexane $/{ }^{i} \mathrm{PrOH}=70: 30$; flow rate $=0.5 \mathrm{~mL} / \mathrm{min} ; \lambda=$ $272 \mathrm{~nm} ; \mathrm{t}_{\mathrm{R} 1}($ major $)=17.0 \mathrm{~min} ; \mathrm{t}_{\mathrm{R} 2}($ minor $)=18.7 \mathrm{~min}$.

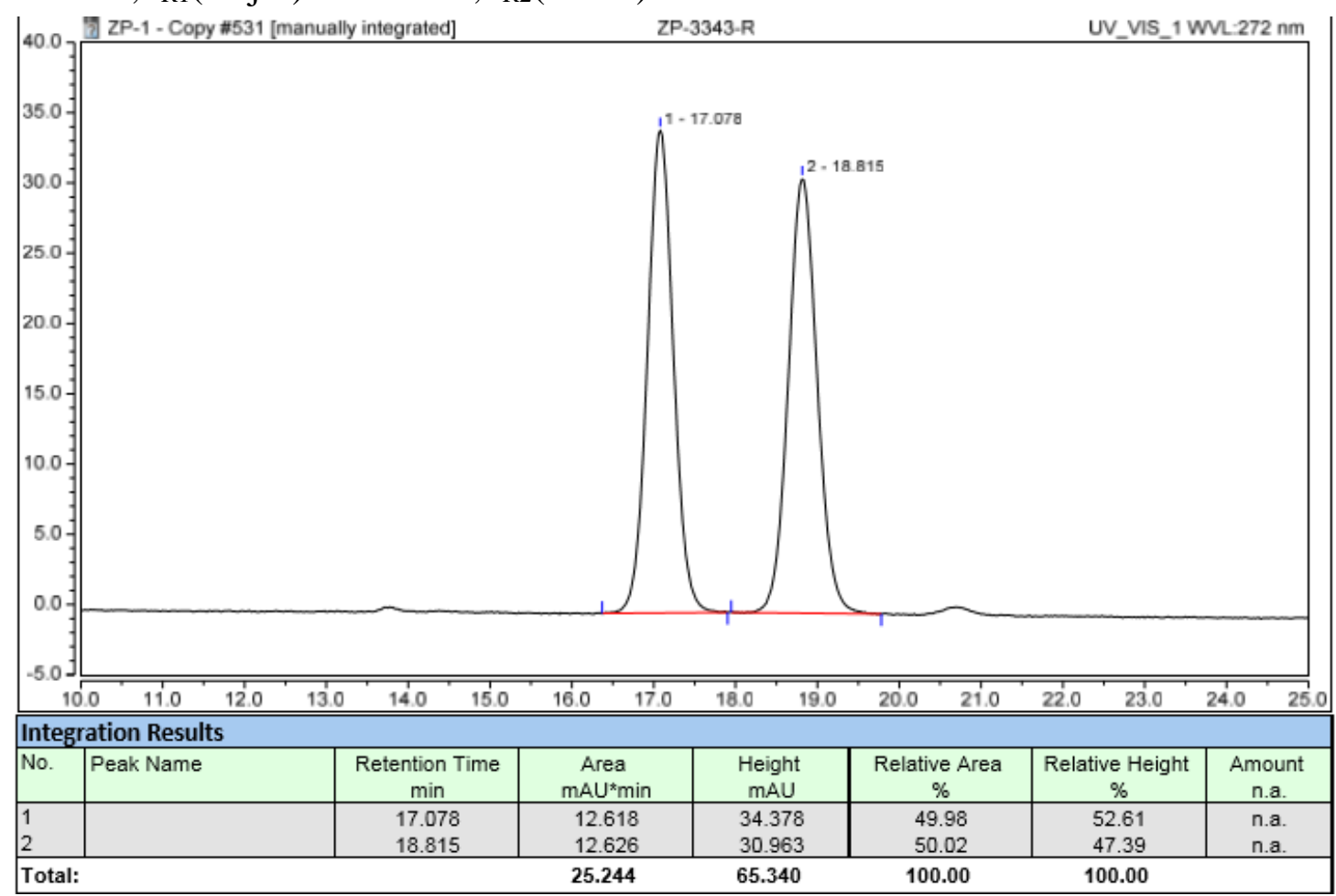




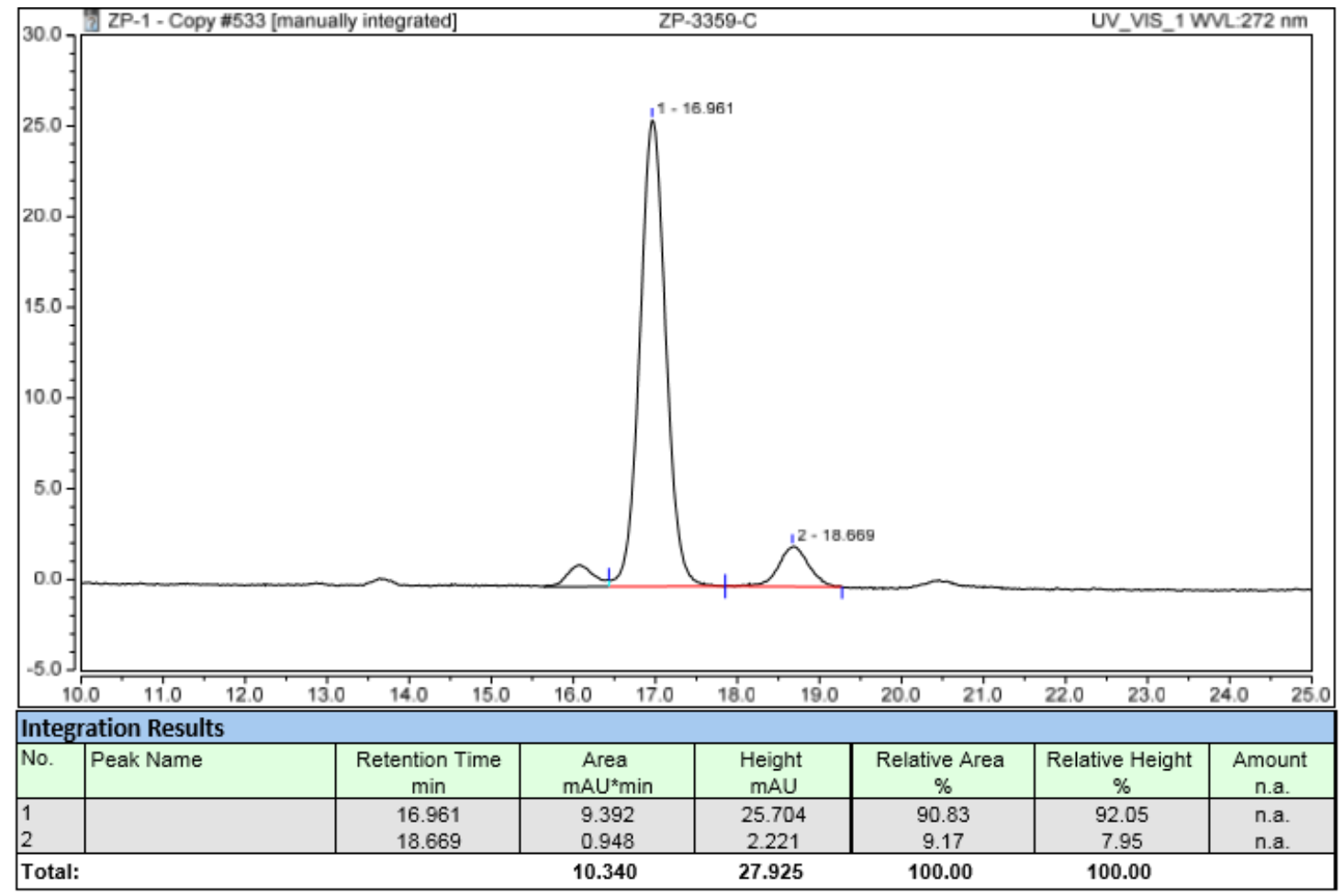




\section{Supplimentary References}

[1] Y. Liang, G. C. Fu, J. Am. Chem. Soc. 2015, 137, 9523-9526.

[2] Y. Liang, G. C. Fu, Angew. Chem. Int. Ed. 2015, 54, 9047-9051.

[3] X. Li, Z. Feng, Z.-X. Jiang, X. Zhang, Org. Lett. 2015, 17, 5570-5573.

[4] Y. Min, J. Sheng, J-L. Yu, S-X. Ni, G. Ma, H. Gong, X-S. Wang, Angew. Chem., Int. Ed. 2021, doi.org/10.1002/anie.202101076.

[5] A. Varenikov, M. Gandelman, Nat. Commun. 2018, 9, 3566.

[6] M. Chen, A. J. Rago, G. Dong, Angew. Chem. Int. Ed. 2018, 130, 16205-16209.

[7] A. Venning, M. Kwiatkowski, J. Pena, B. Lainhart,A. Guruparan, E. Alexanian, J. Am. Chem. Soc. 2017, 139, 11595-11600.

[8] M. Poornachandran, R. Raghunathan, Tetrahedron. 2008, 64, 6461-6474.

[9] X. Cheng, H. Lu, Z. Lu, Nat. Commun. 2019, 10, 3549. 


\section{Spectra data for the compounds}

Compound 2s ${ }^{1} \mathrm{H}$ NMR (600 MHz, $\mathrm{CDCl}_{3}$ )

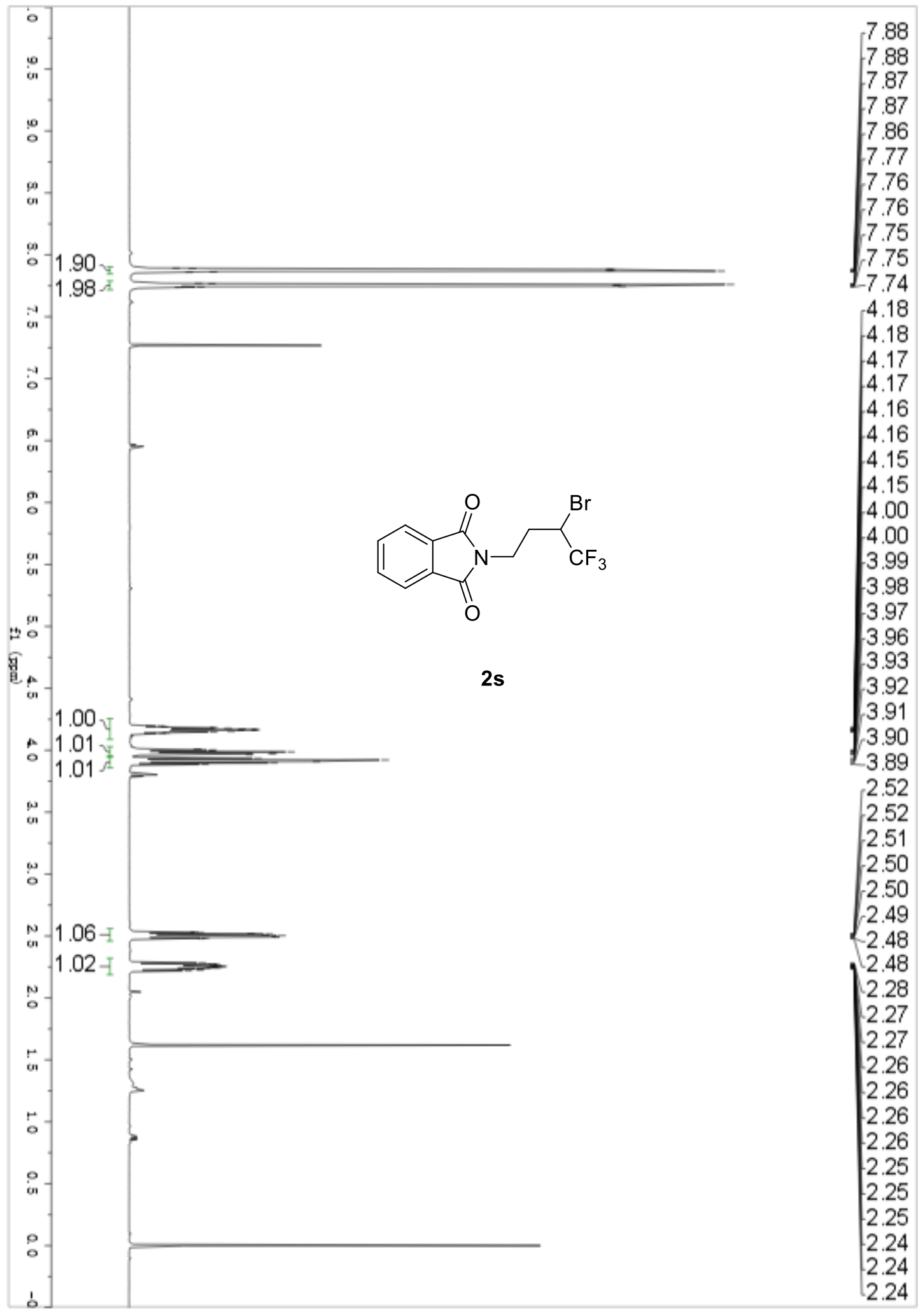


Compound 2s ${ }^{13} \mathrm{C}$ NMR (151 MHz, $\left.\mathrm{CDCl}_{3}\right)$

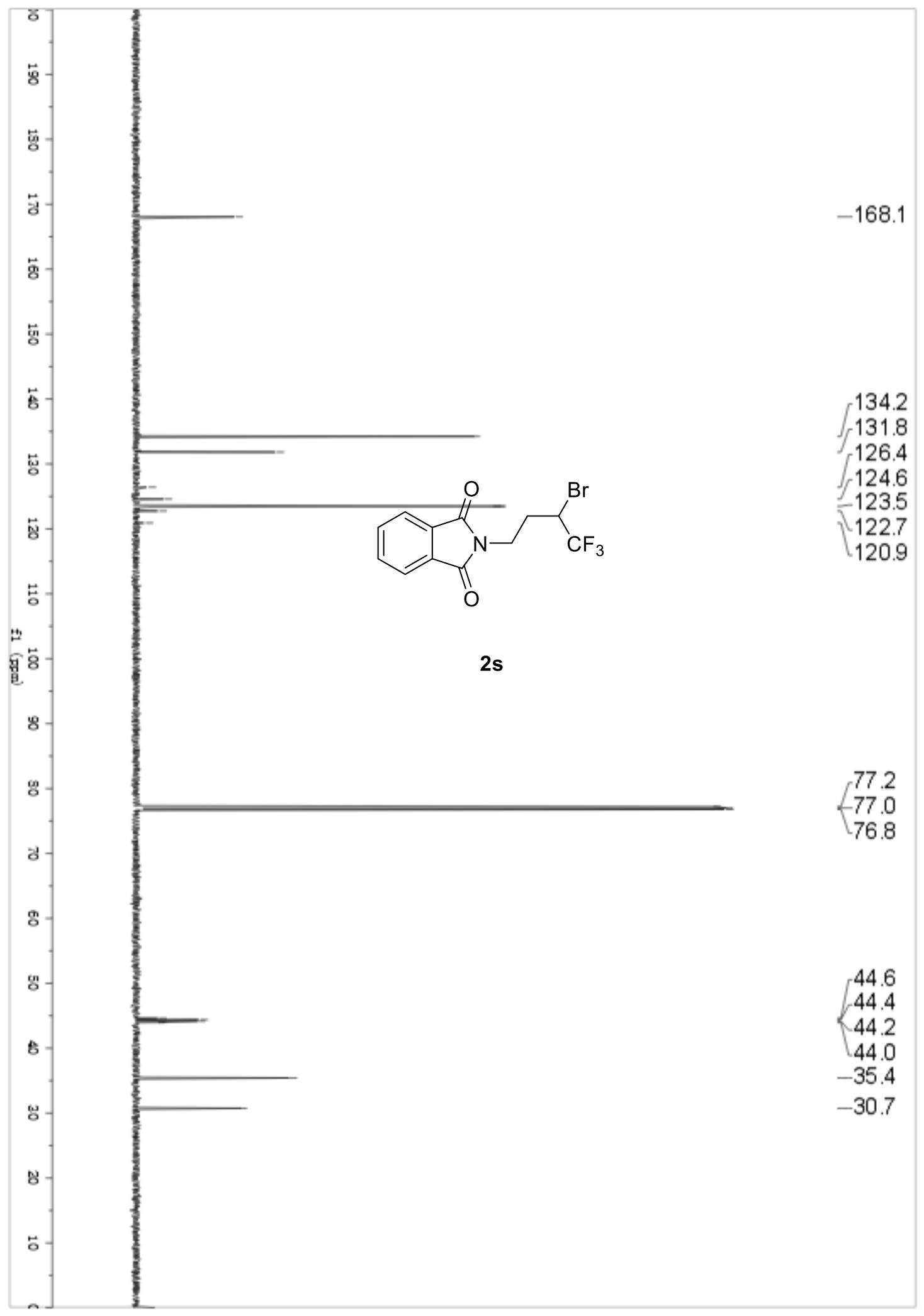


Compound 2s ${ }^{1} \mathrm{~F}$ NMR (565 MHz, $\mathrm{CDCl}_{3}$ )

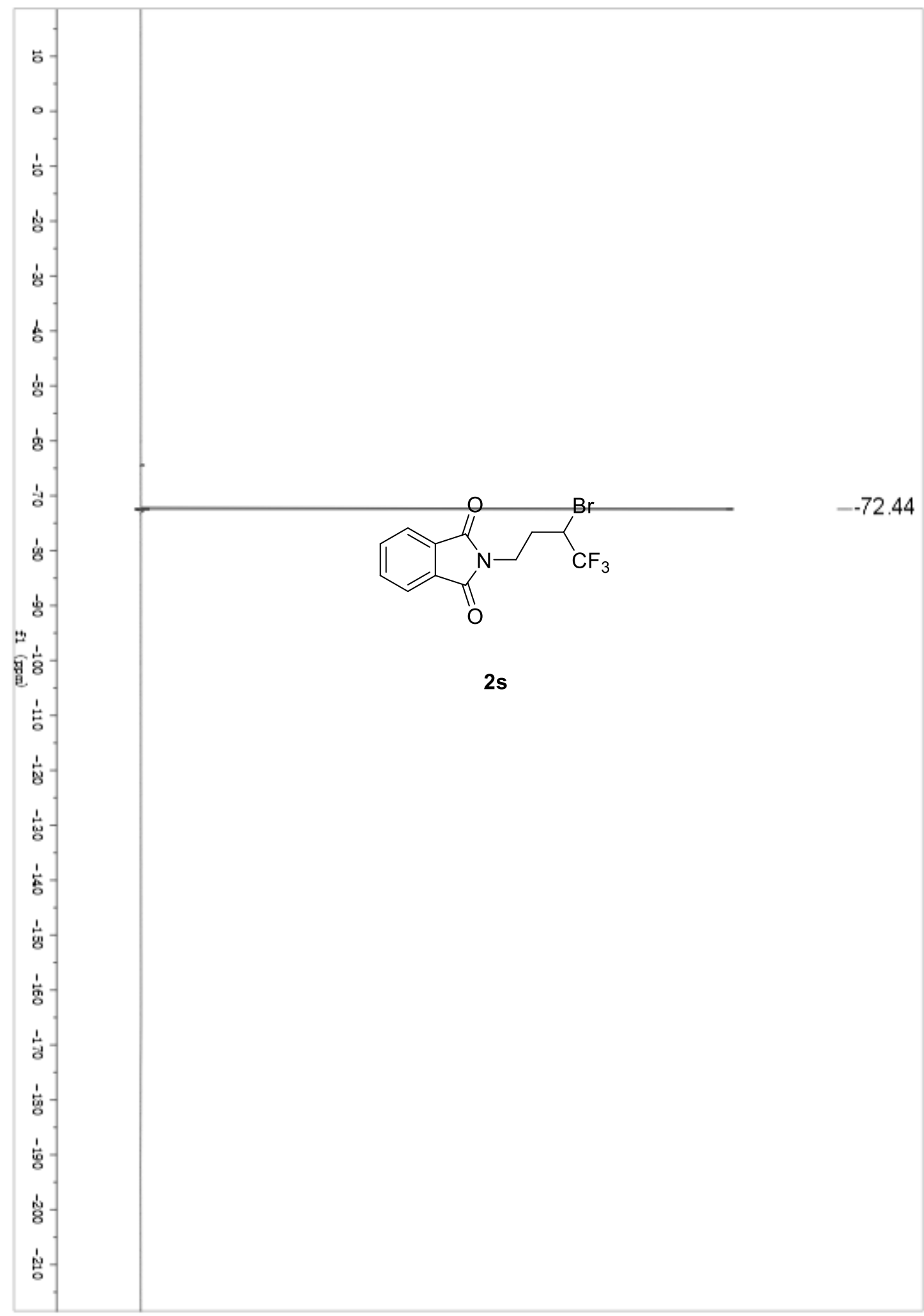


Compound 2w ${ }^{1} \mathrm{H}$ NMR (600 MHz, $\mathrm{CDCl}_{3}$ )

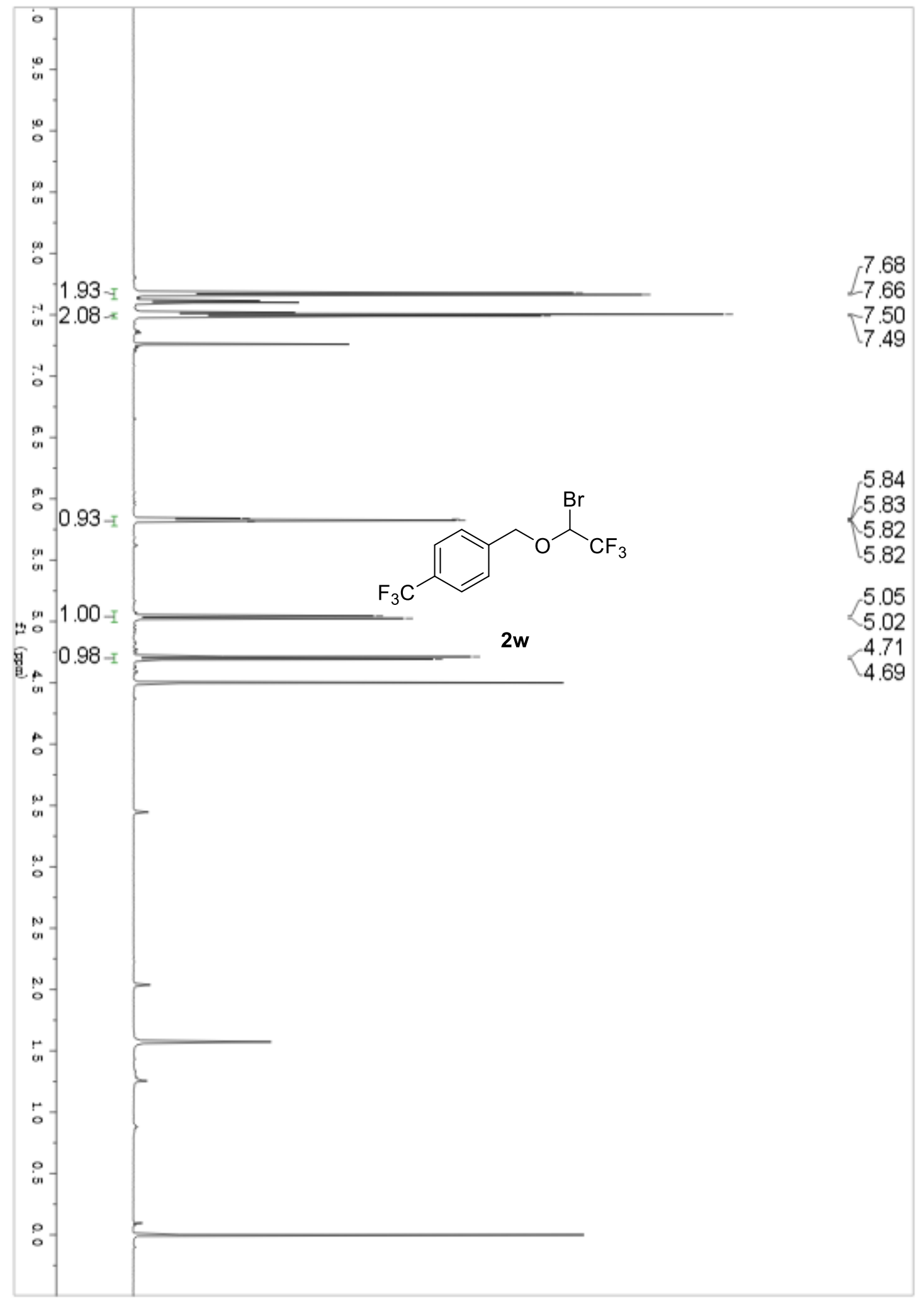


Compound 2w ${ }^{13} \mathrm{C}$ NMR (151 MHz, $\mathrm{CDCl}_{3}$ )

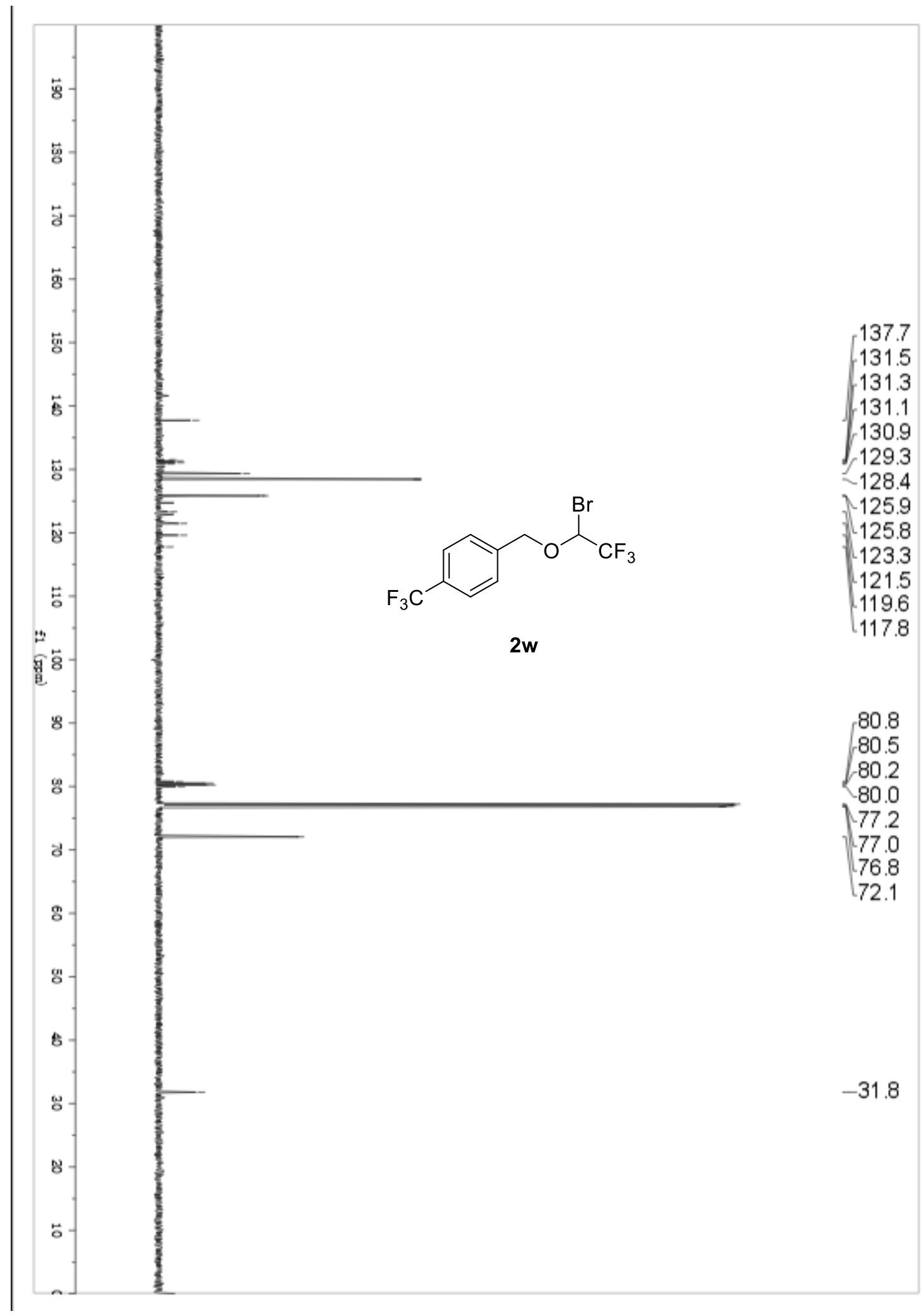


Compound $2 \mathbf{w}^{19} \mathrm{~F}$ NMR (565 MHz, $\mathrm{CDCl}_{3}$ )

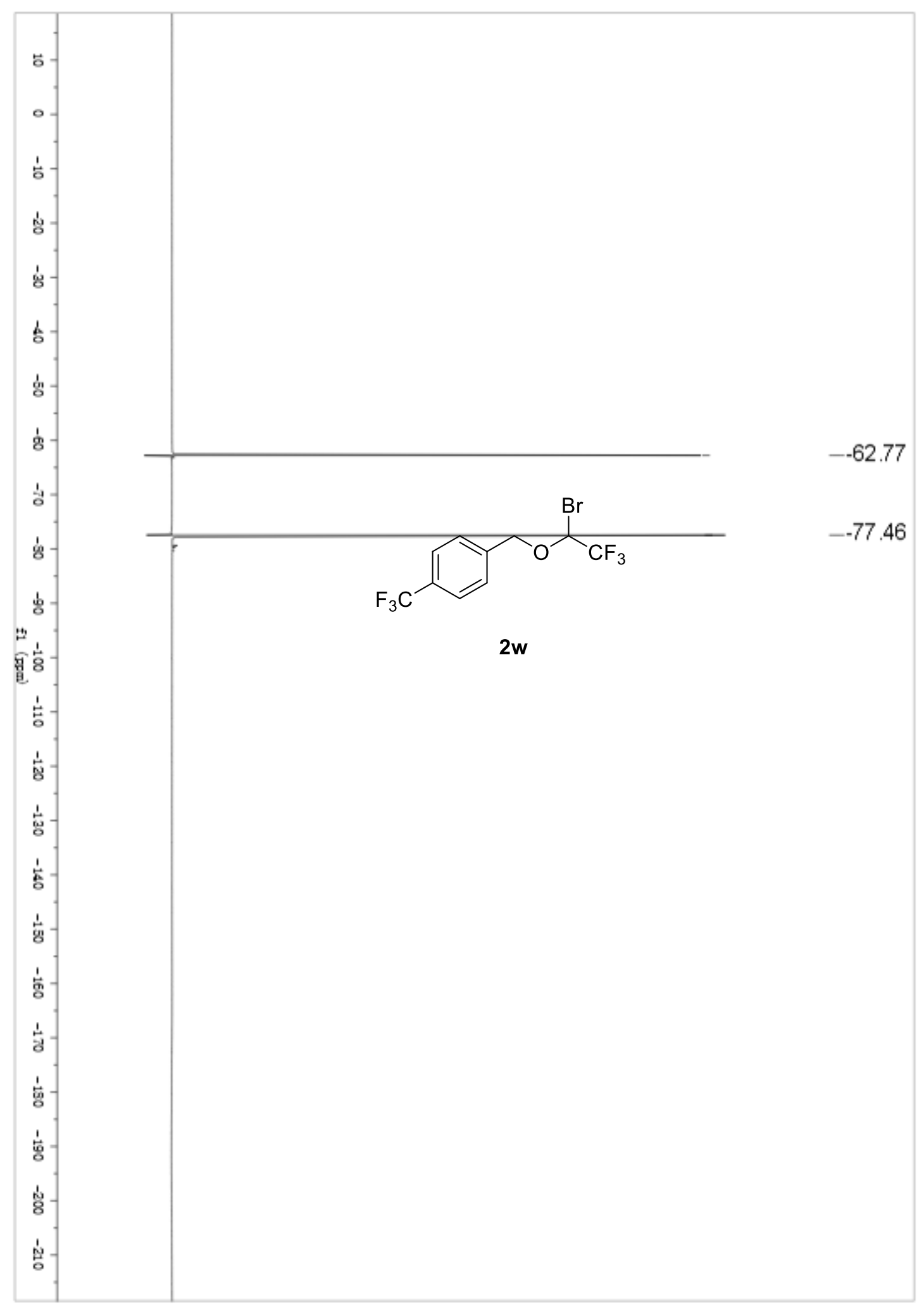


Compound 2dd ${ }^{1} \mathrm{H}$ NMR (600 MHz, $\left.\mathrm{CDCl}_{3}\right)$

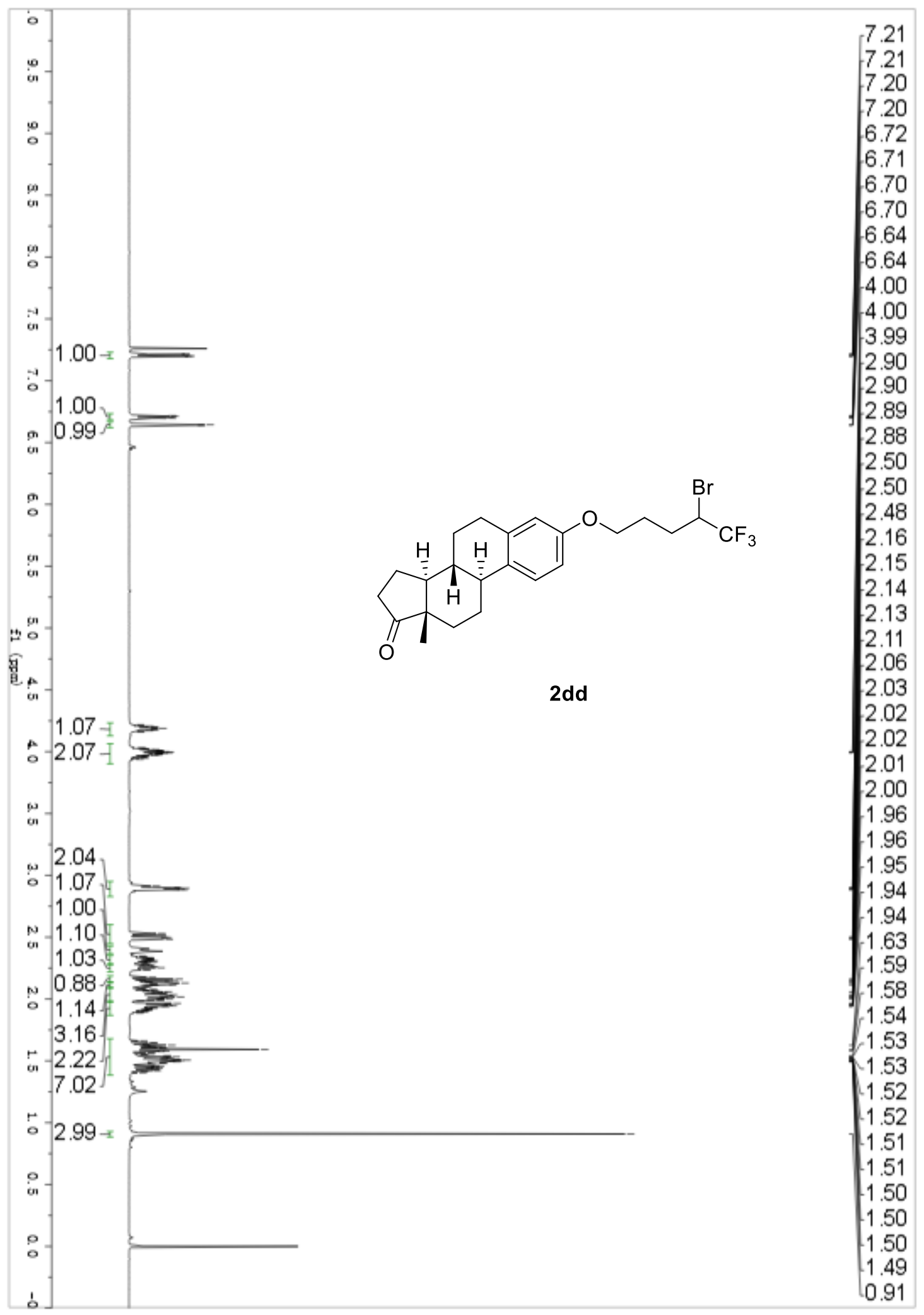


Compound 2dd ${ }^{13} \mathrm{C}$ NMR (151 MHz, $\mathrm{CDCl}_{3}$ )

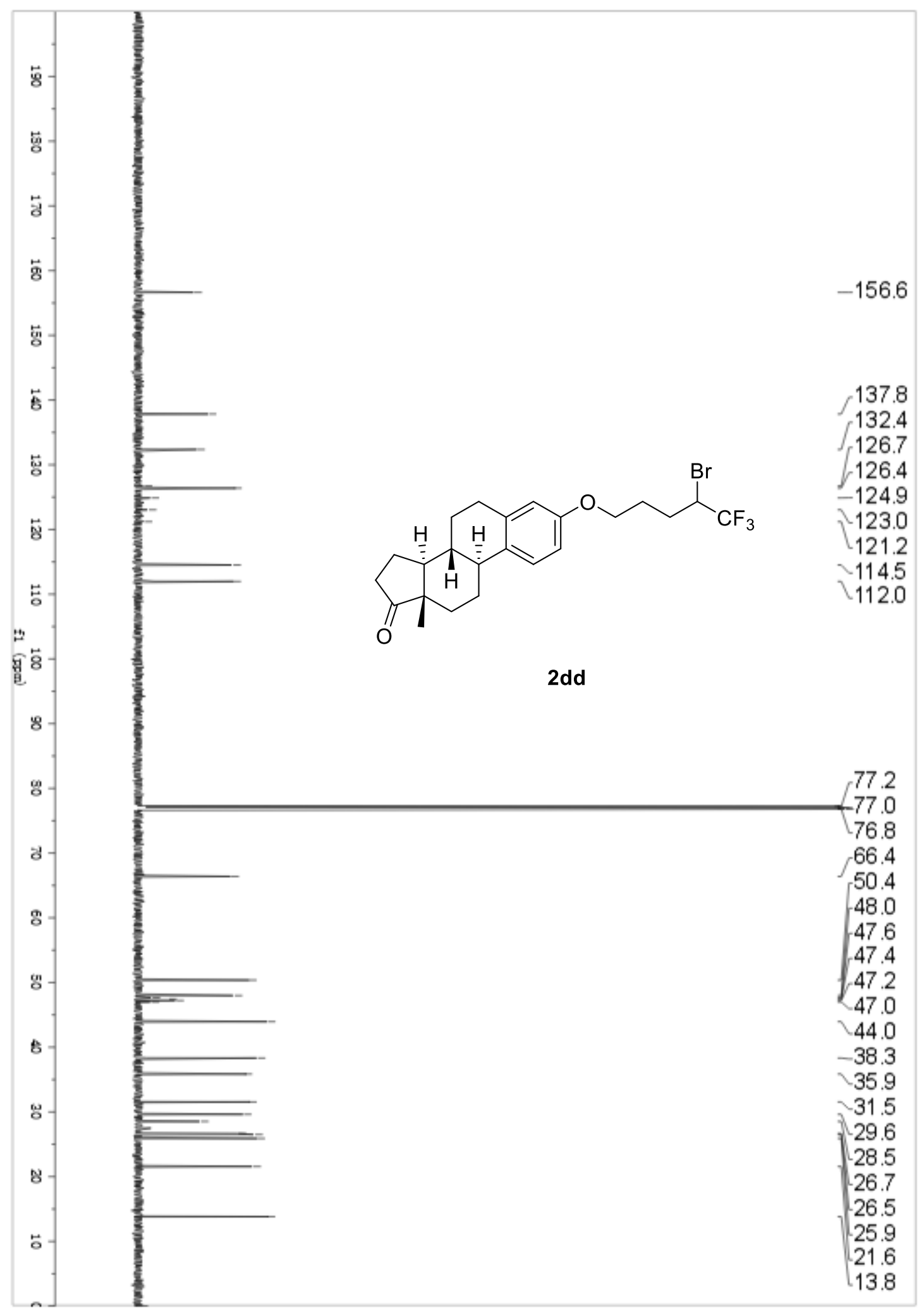


Compound 2dd ${ }^{19} \mathrm{~F}$ NMR (565 MHz, $\mathrm{CDCl}_{3}$ )

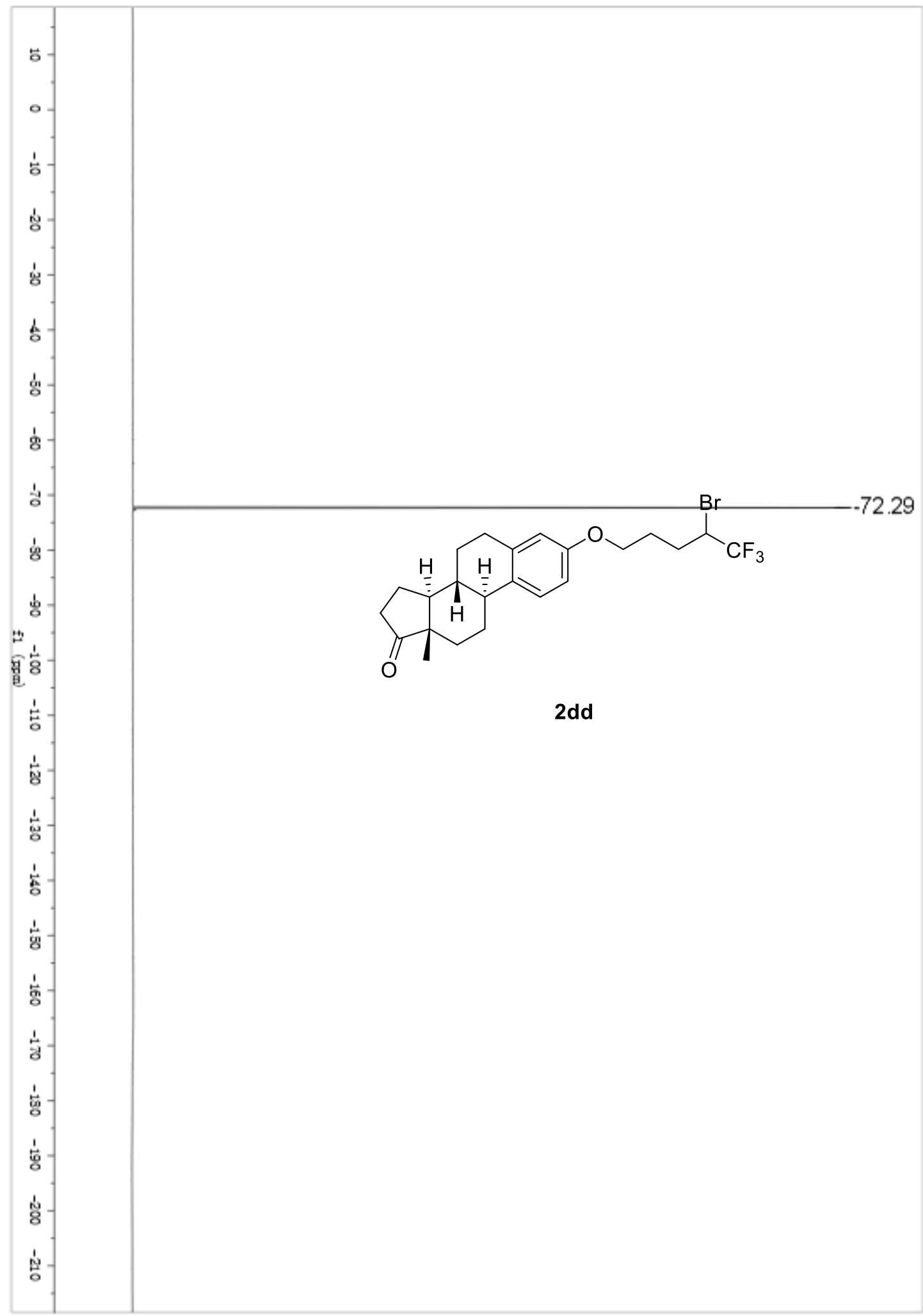


Compound $\mathbf{L 2}{ }^{1} \mathrm{H}$ NMR (600 MHz, $\mathrm{CDCl}_{3}$ )

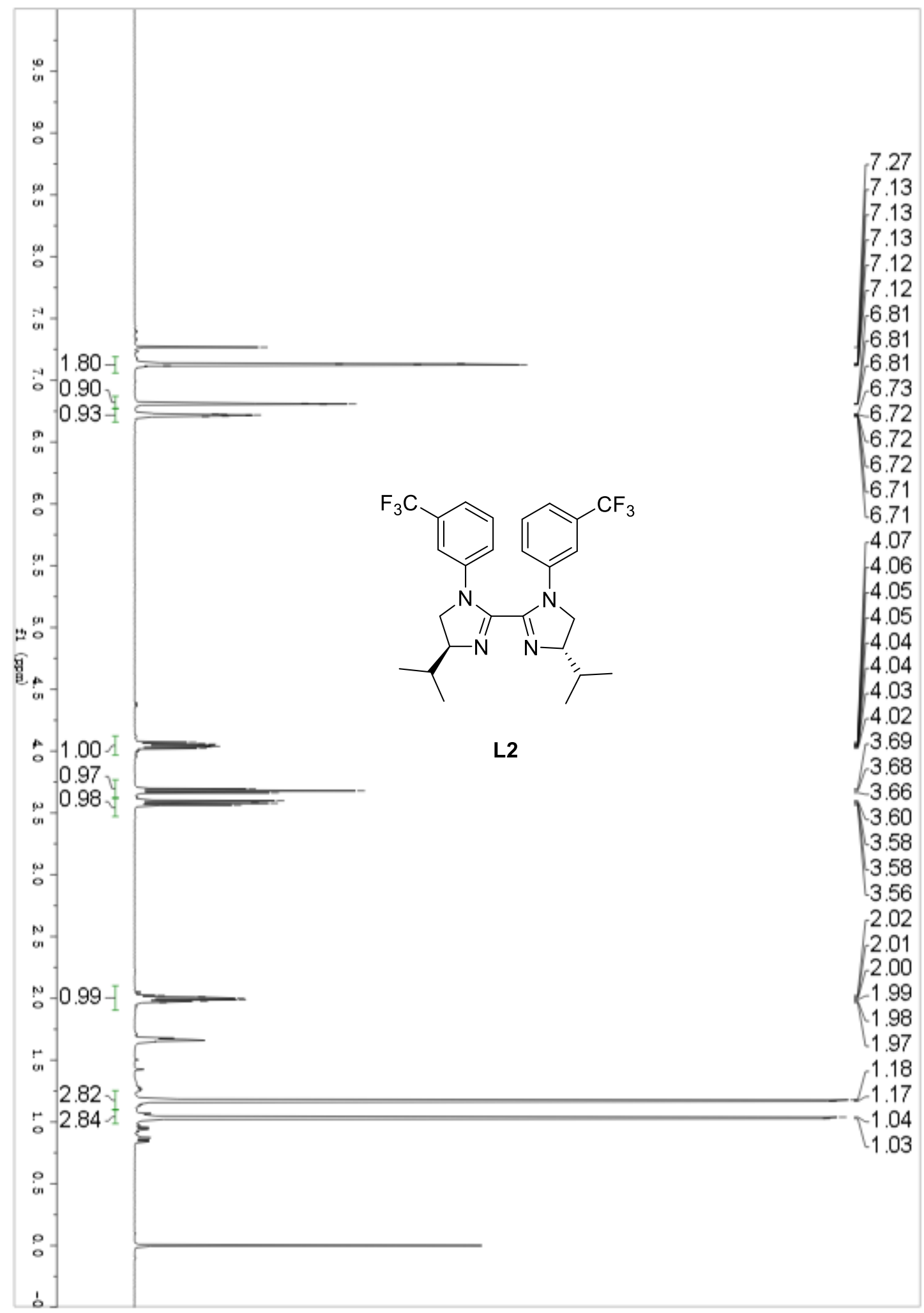


Compound L2 ${ }^{13} \mathrm{C}$ NMR (151 MHz, $\mathrm{CDCl}_{3}$ )

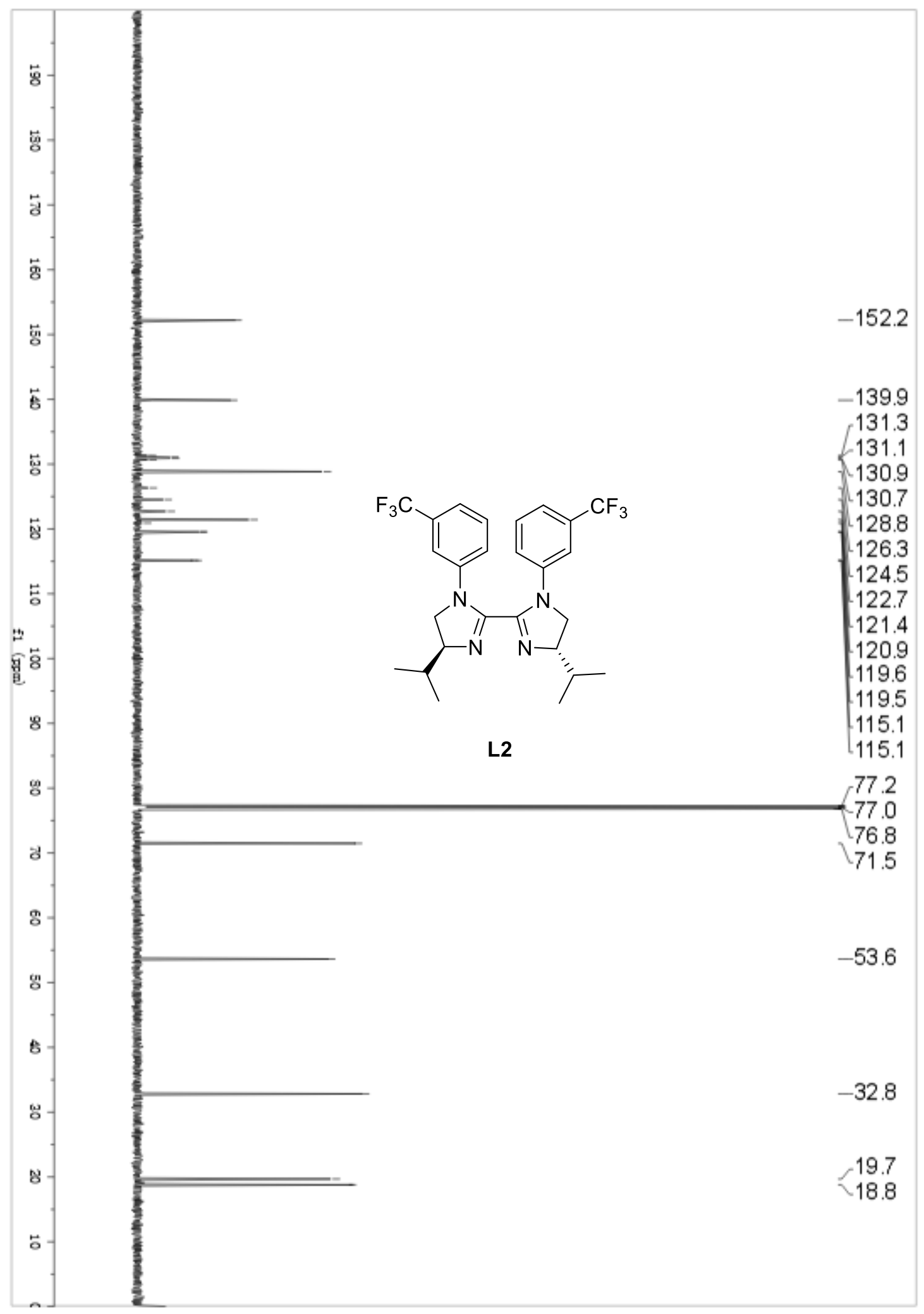


Compound L2 ${ }^{19} \mathrm{~F}$ NMR (565 MHz, $\mathrm{CDCl}_{3}$ )

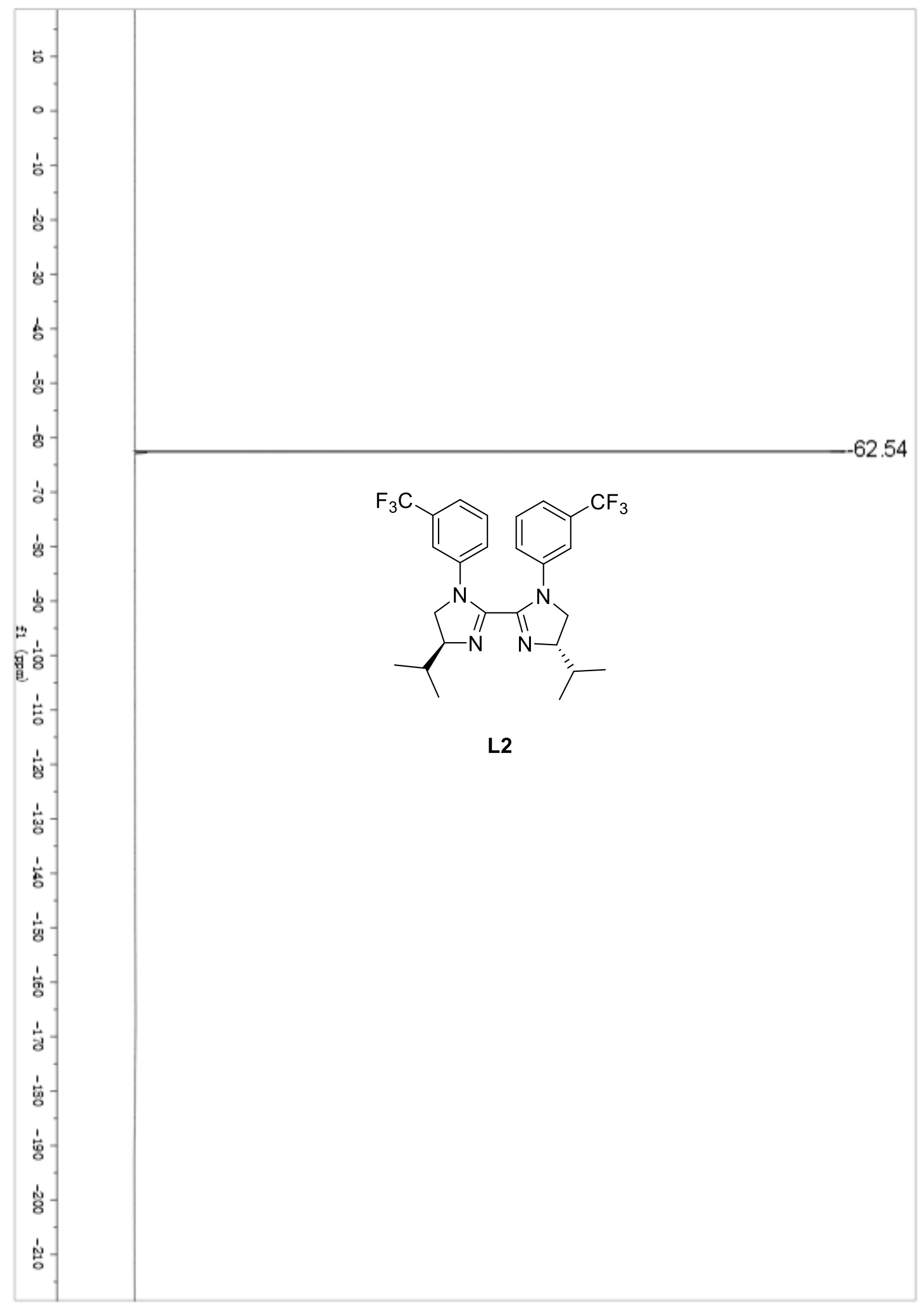


Compound 3a ${ }^{1} \mathrm{H}$ NMR (600 MHz, $\left.\mathrm{CDCl}_{3}\right)$

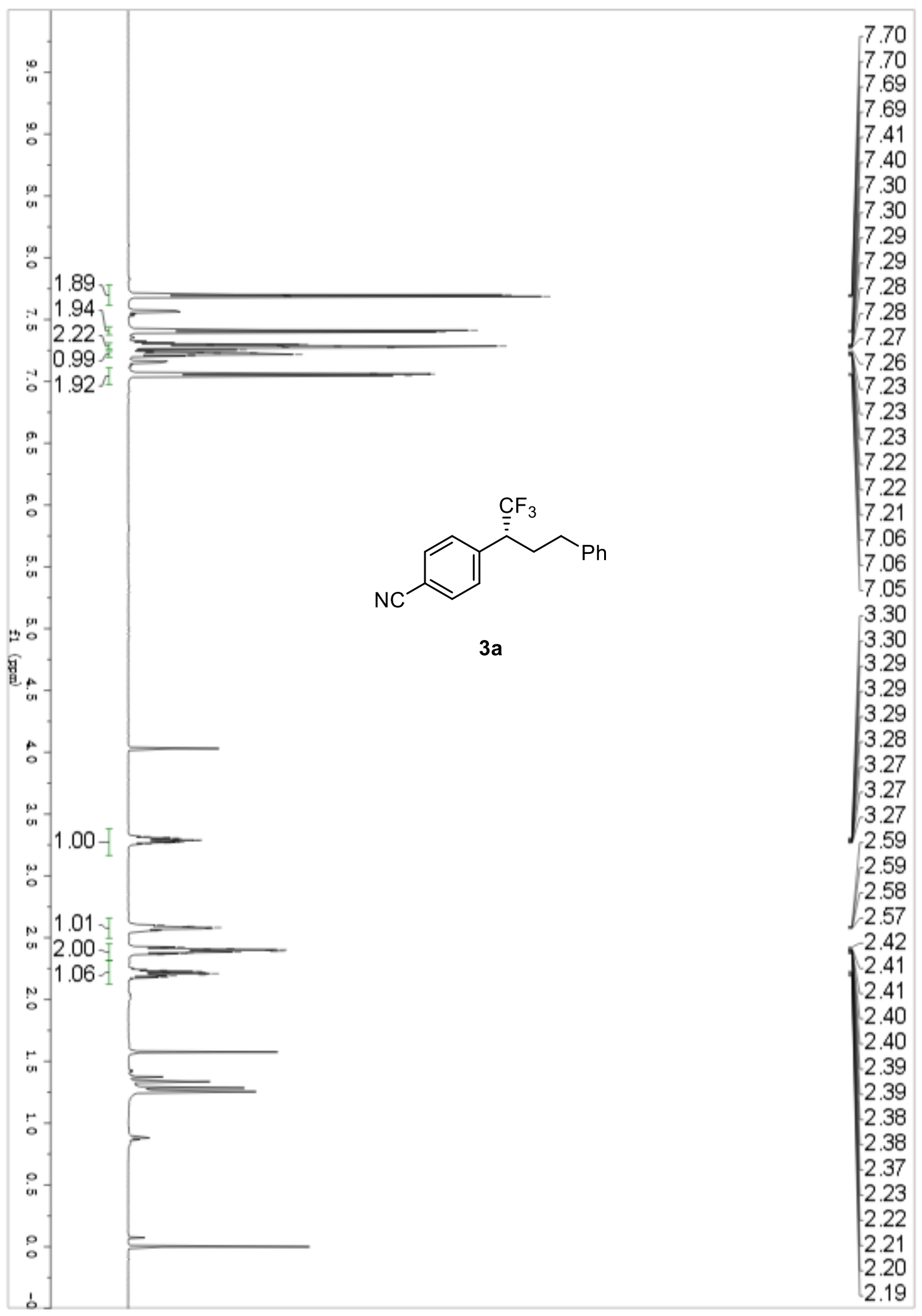


Compound 3a ${ }^{13} \mathrm{C}$ NMR (151 MHz, $\left.\mathrm{CDCl}_{3}\right)$

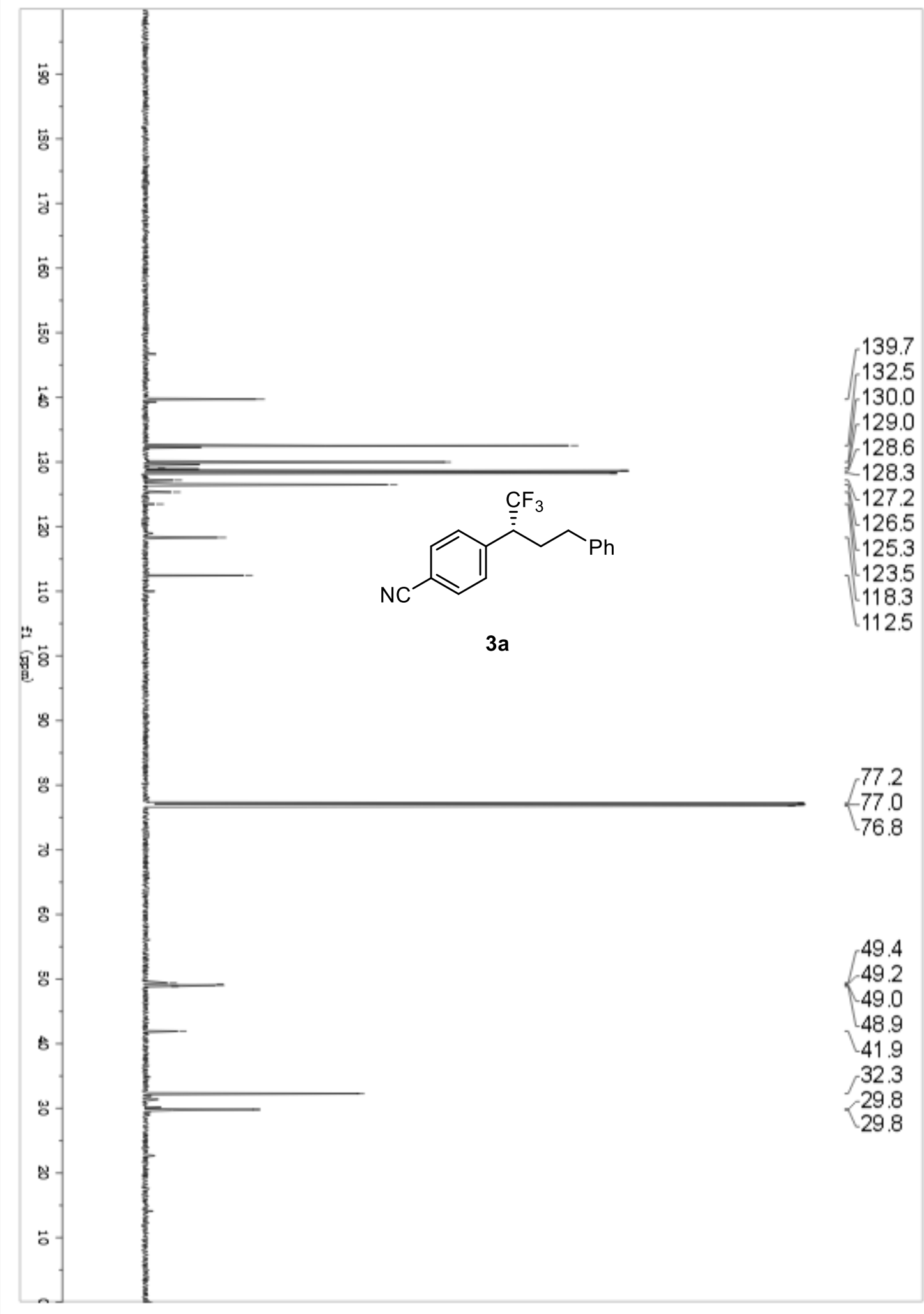


Compound 3a ${ }^{19} \mathrm{~F}$ NMR (565 MHz, $\mathrm{CDCl}_{3}$ )

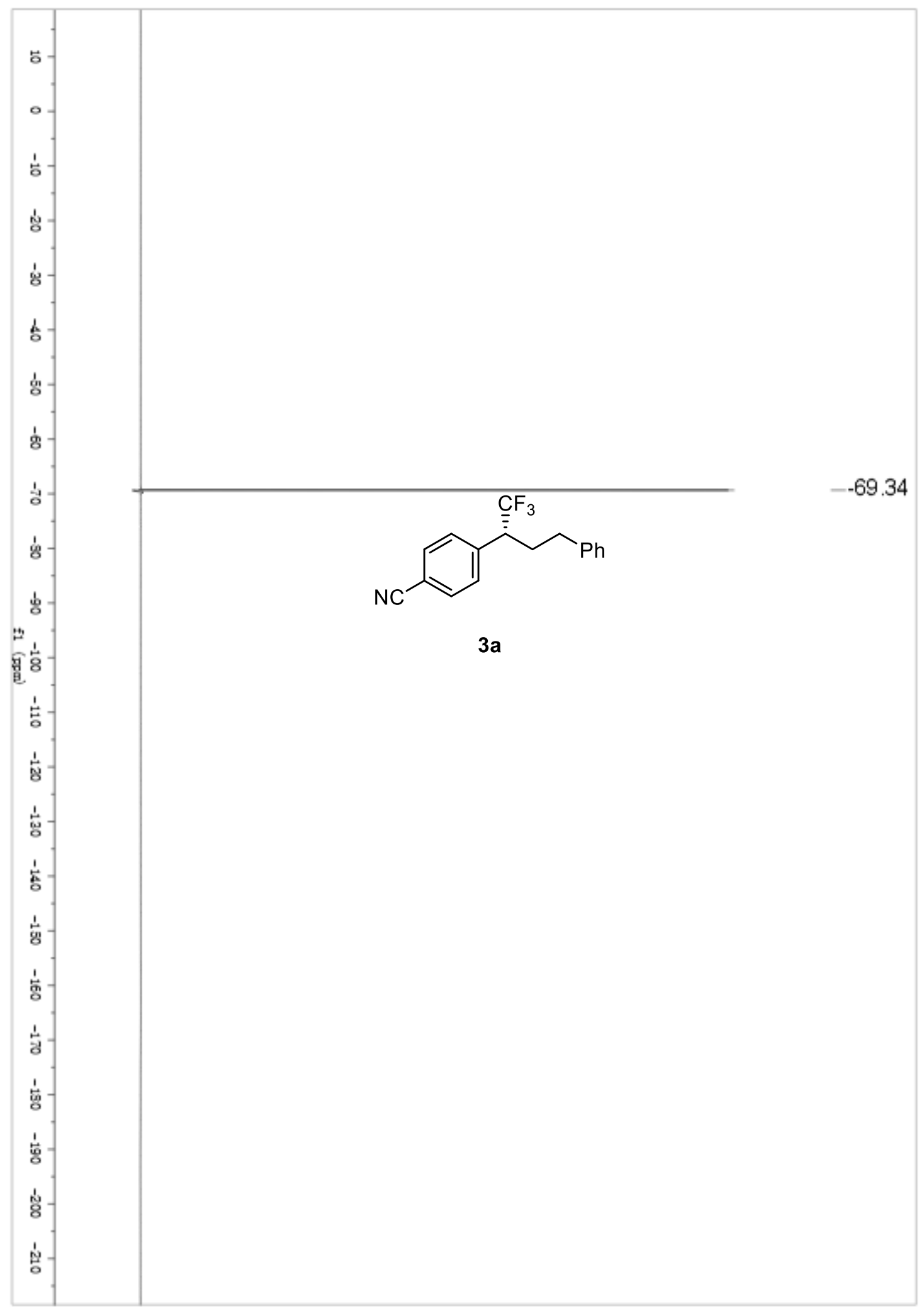


Compound 3b ${ }^{1} \mathrm{H}$ NMR (400 MHz, $\left.\mathrm{CDCl}_{3}\right)$

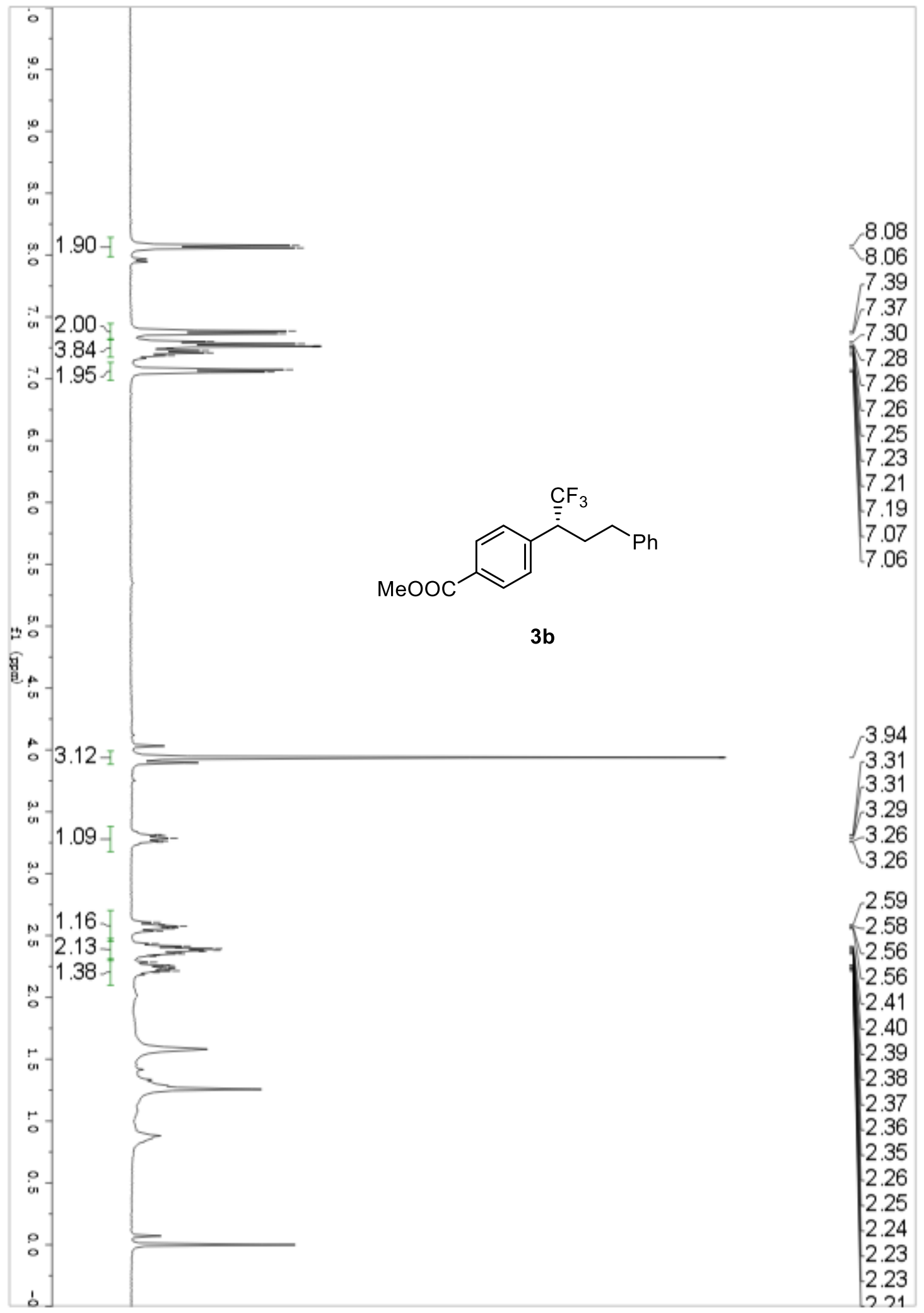


Compound 3C ${ }^{1} \mathrm{H}$ NMR (400 MHz, $\mathrm{CDCl}_{3}$ )

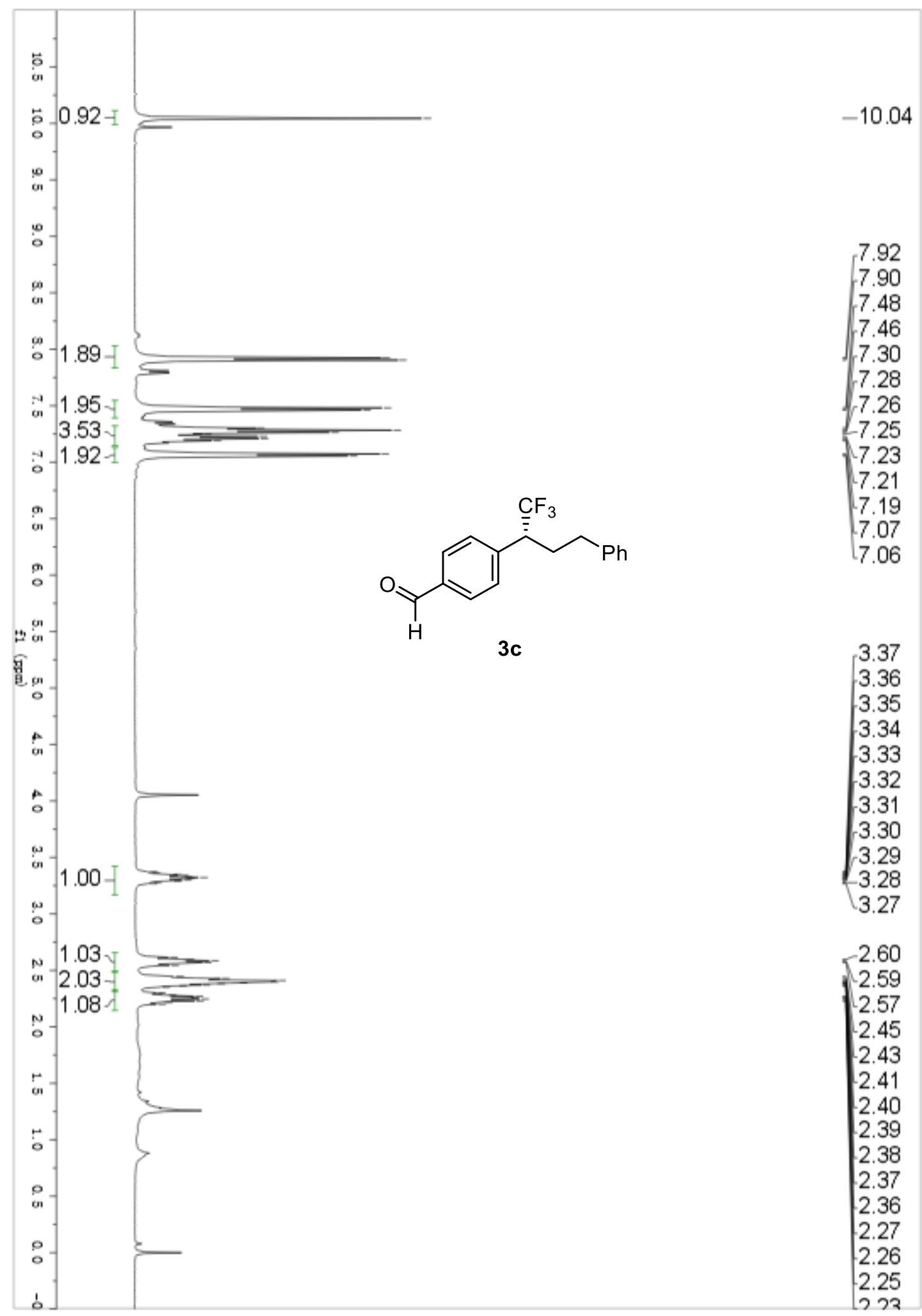


Compound 3d ${ }^{1} \mathrm{H}$ NMR (400 MHz, $\left.\mathrm{CDCl}_{3}\right)$

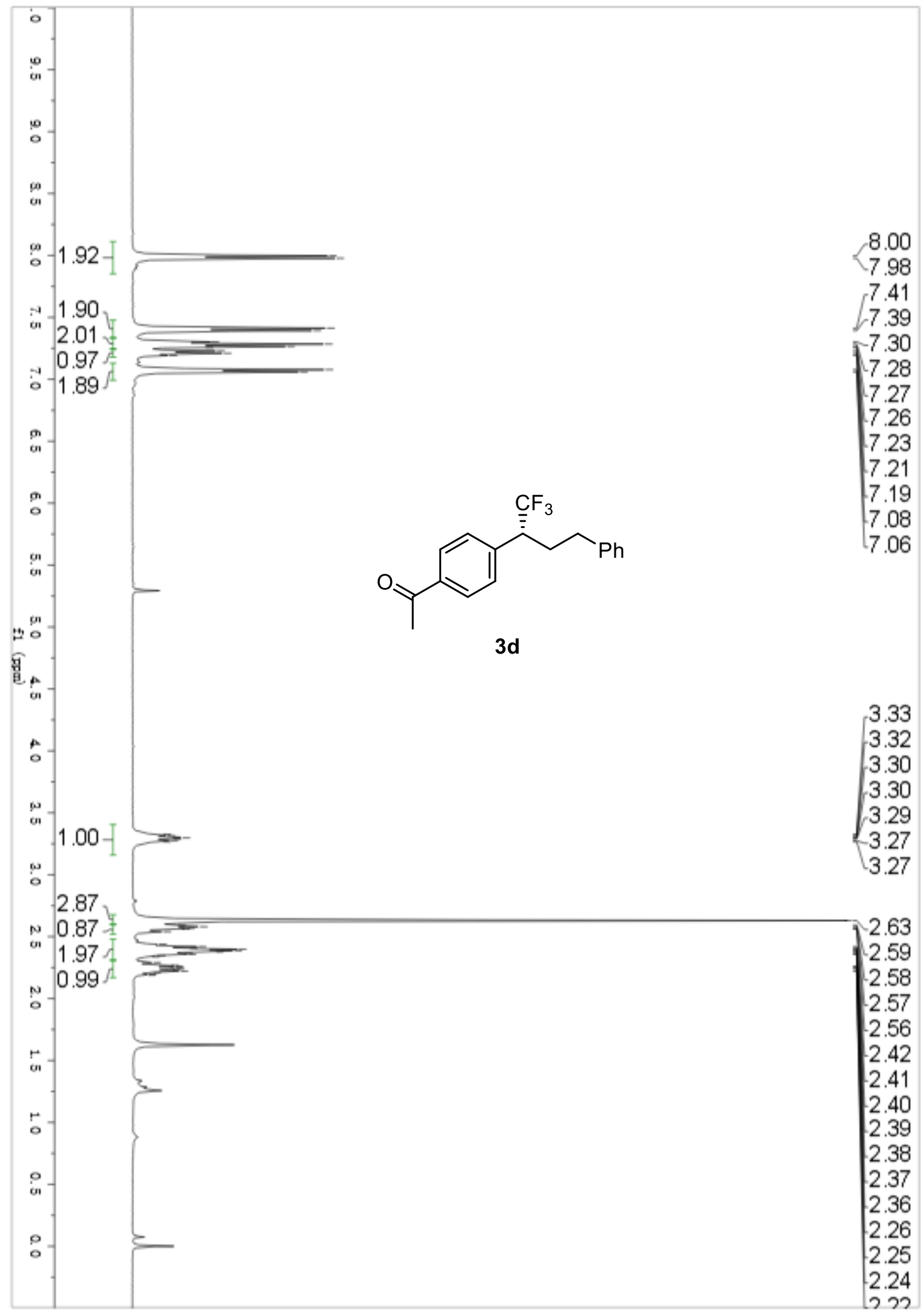


Compound 3e ${ }^{1} \mathrm{H}$ NMR (400 MHz, $\mathrm{CDCl}_{3}$ )

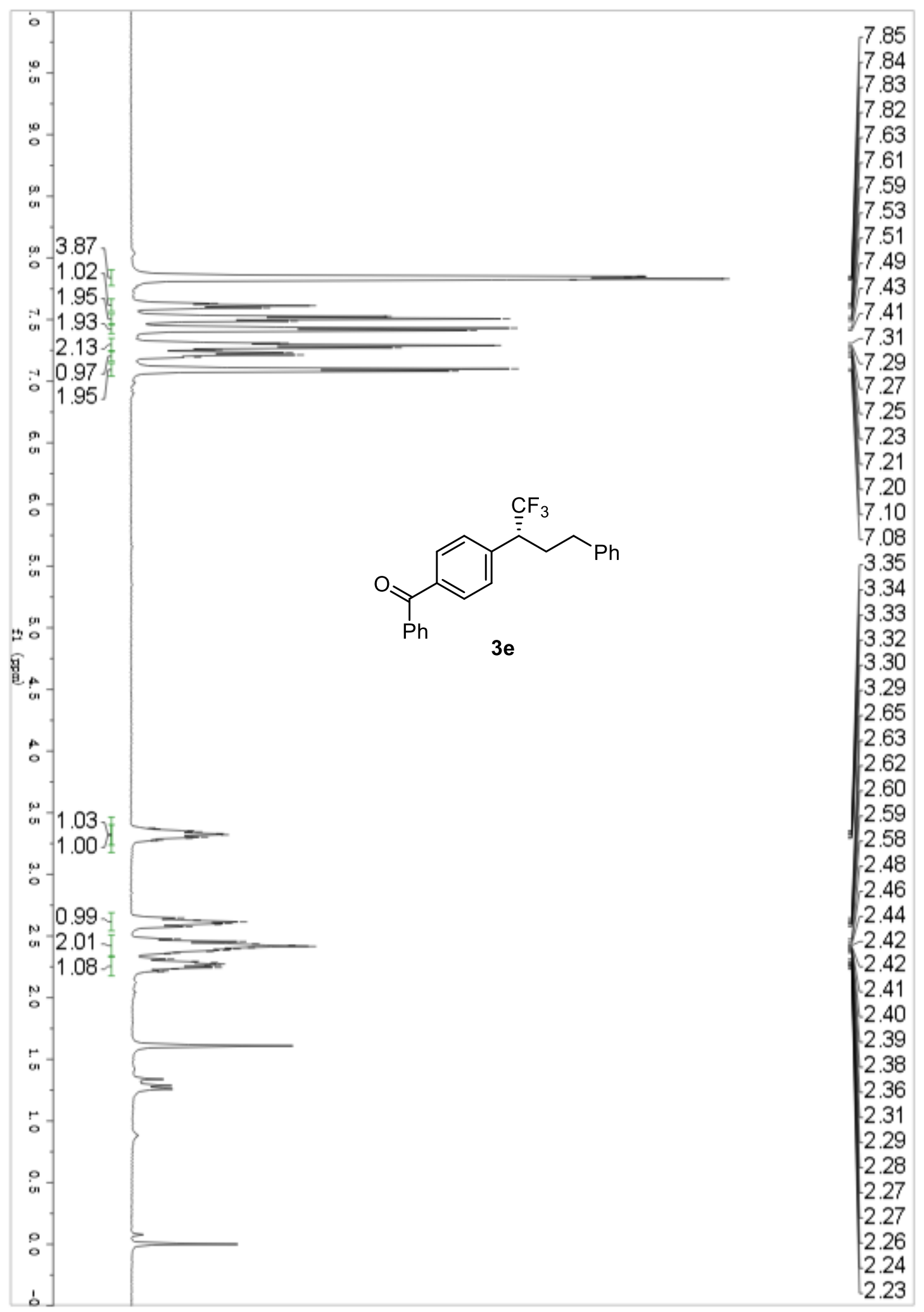


Compound $3 \mathbf{f}^{1} \mathrm{H}$ NMR $\left(600 \mathrm{MHz}, \mathrm{CDCl}_{3}\right)$

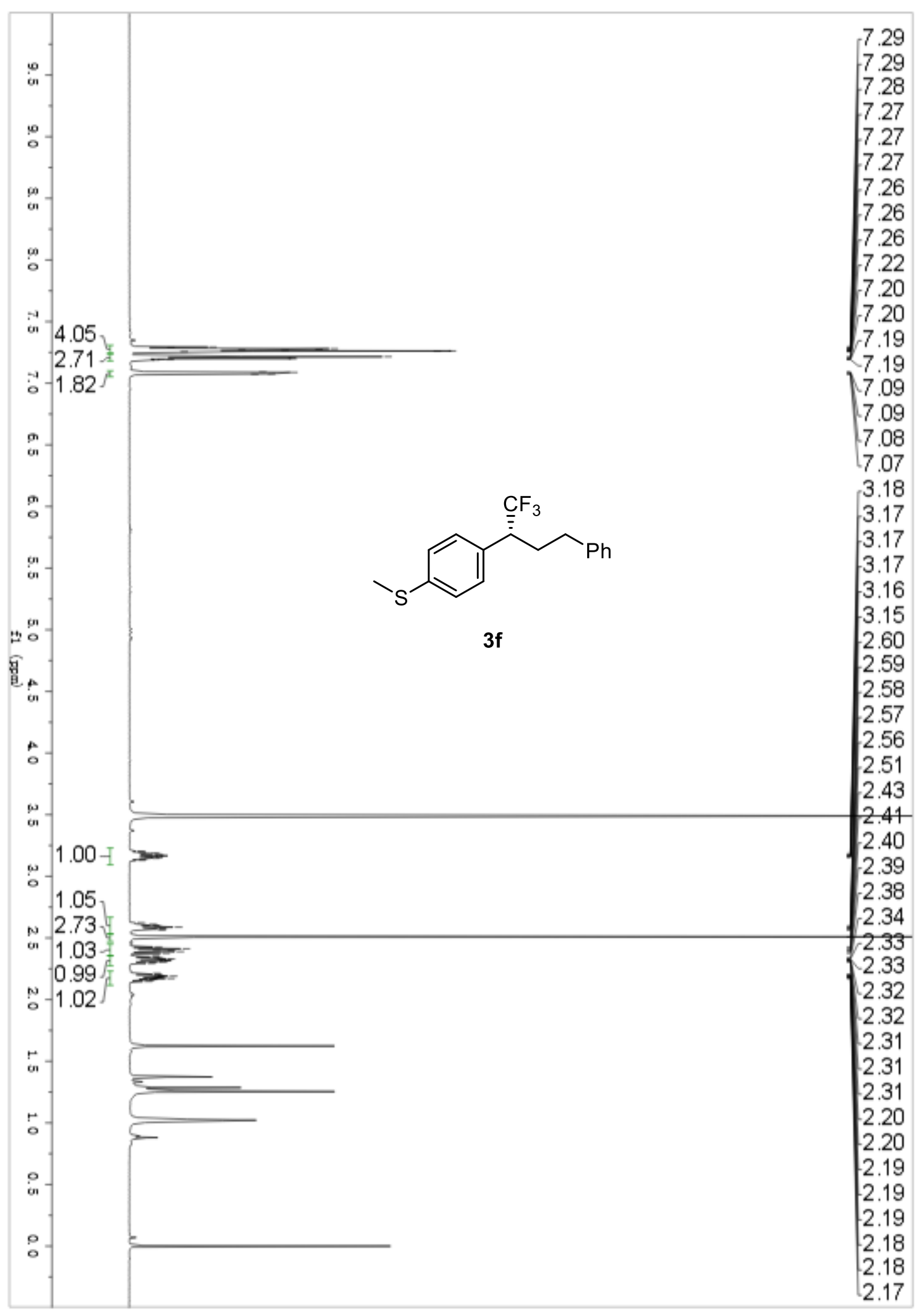


Compound 3g ${ }^{1} \mathrm{H}$ NMR (400 MHz, $\left.\mathrm{CDCl}_{3}\right)$

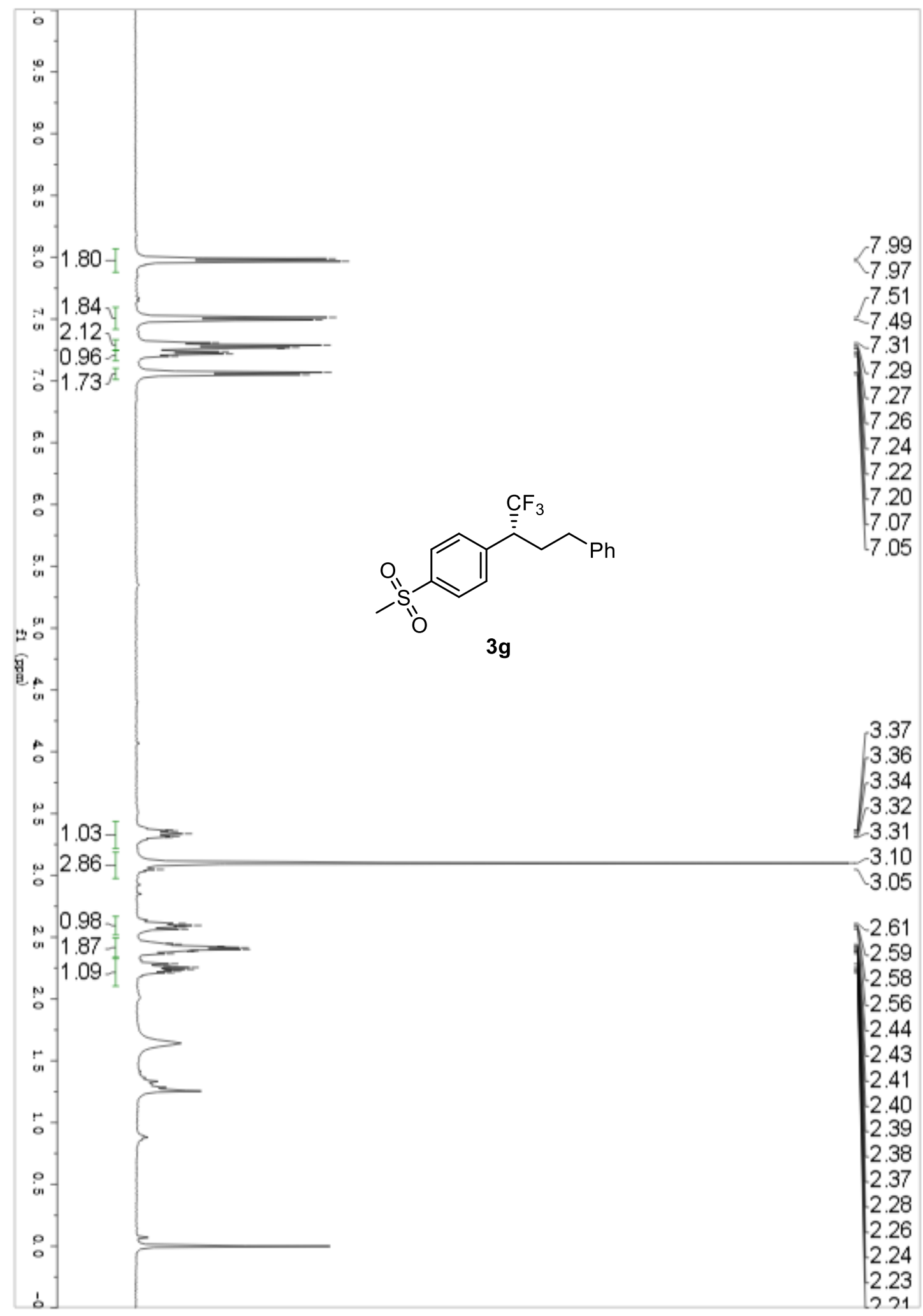


Compound $\mathbf{3 h}{ }^{1} \mathrm{H}$ NMR (400 MHz, $\left.\mathrm{CDCl}_{3}\right)$

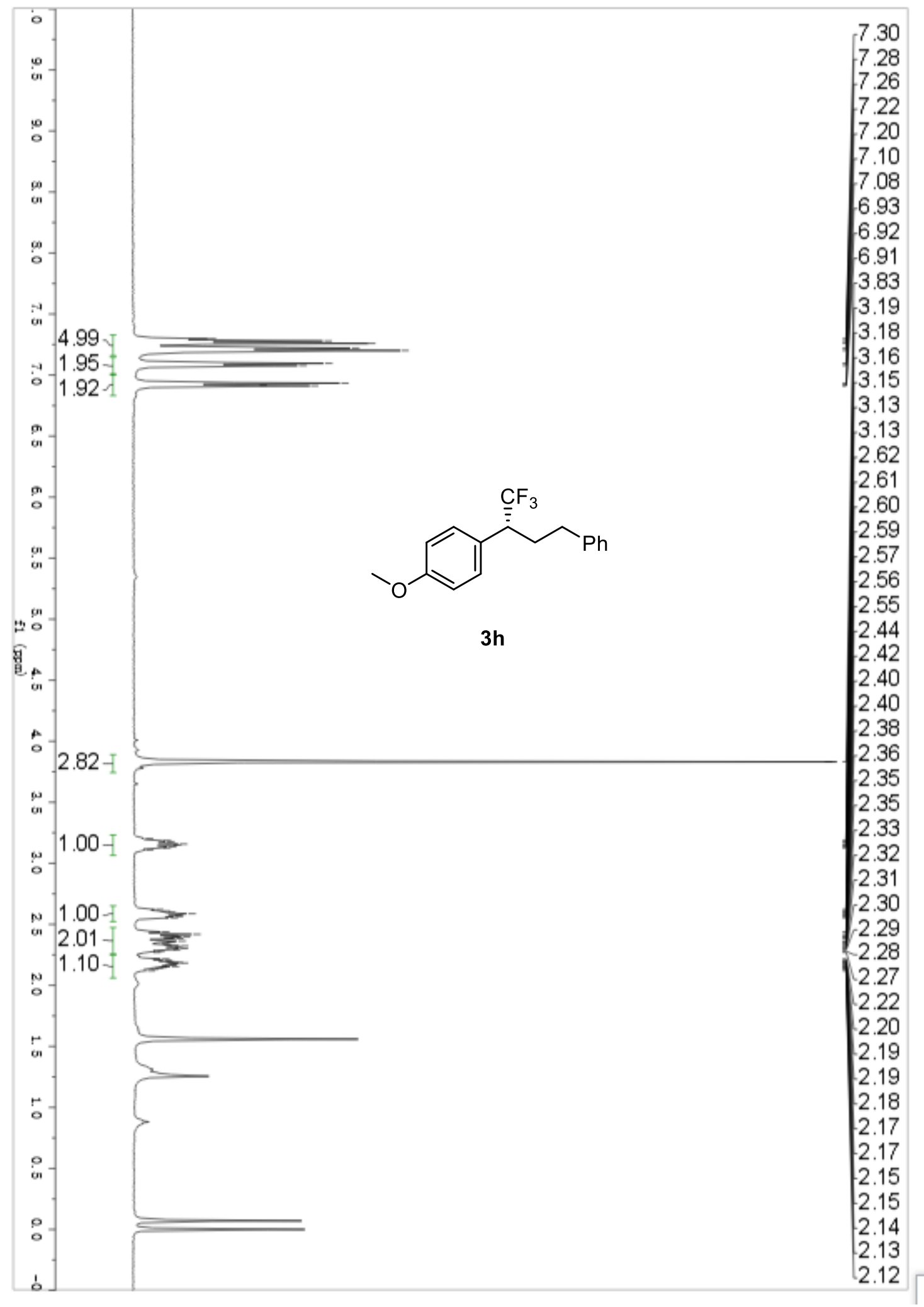


Compound $3 \mathbf{i}^{1} \mathrm{H}$ NMR $\left(400 \mathrm{MHz}, \mathrm{CDCl}_{3}\right.$ )

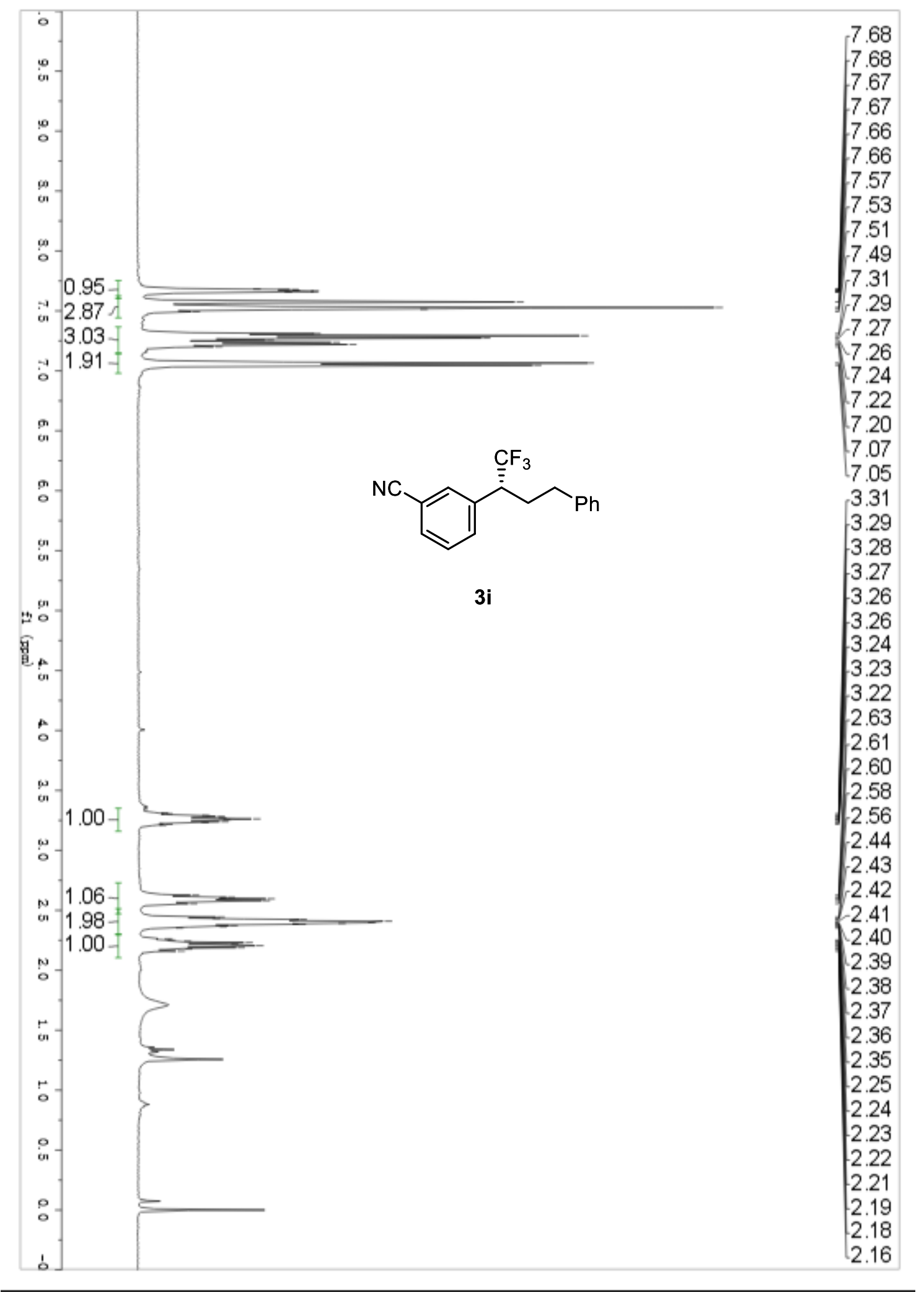


Compound $3 \mathbf{i}^{13} \mathrm{C}$ NMR (101 MHz, $\left.\mathrm{CDCl}_{3}\right)$

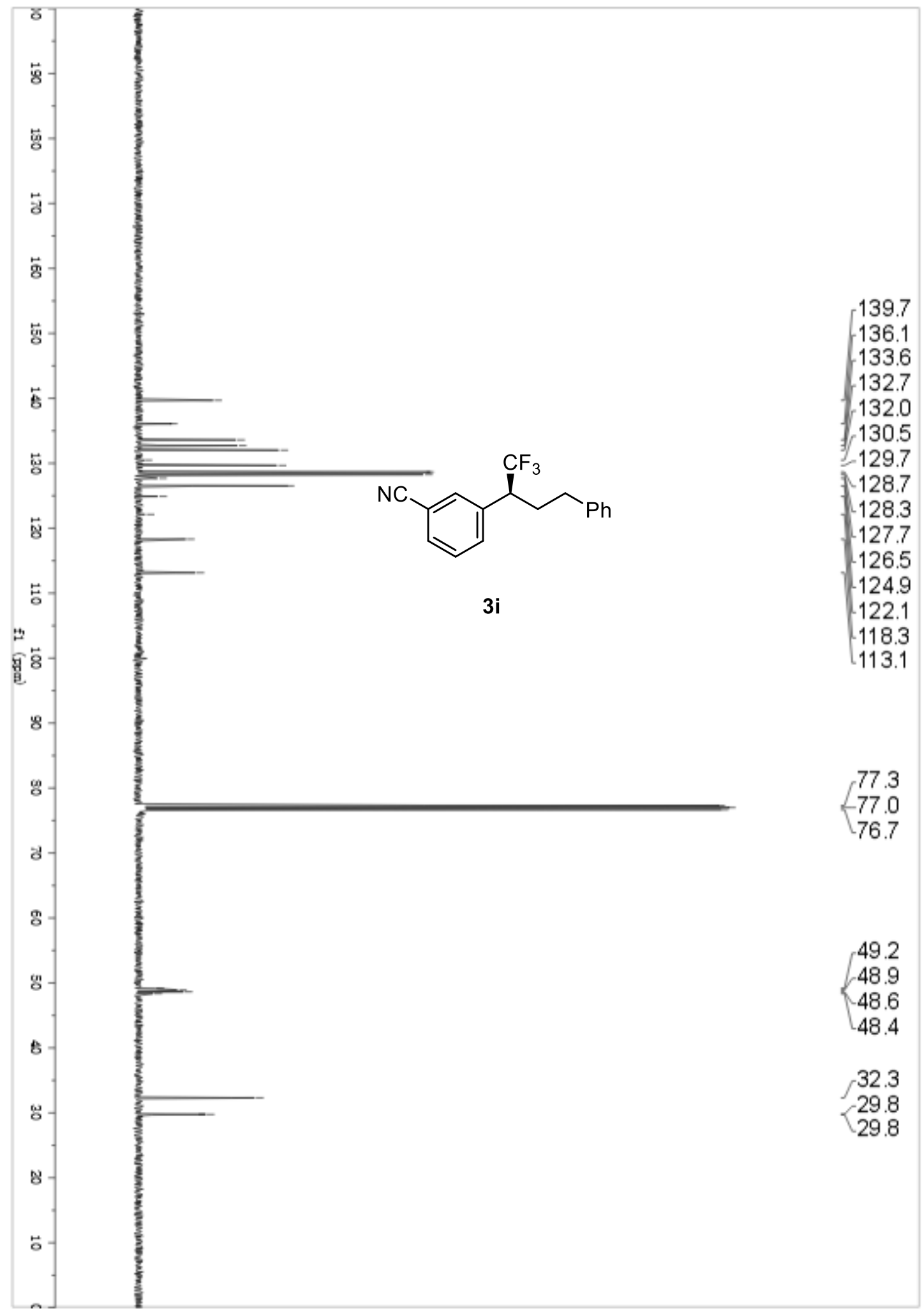


Compound $3 \mathbf{i}^{19} \mathrm{~F}$ NMR (376 MHz, $\mathrm{CDCl}_{3}$ )

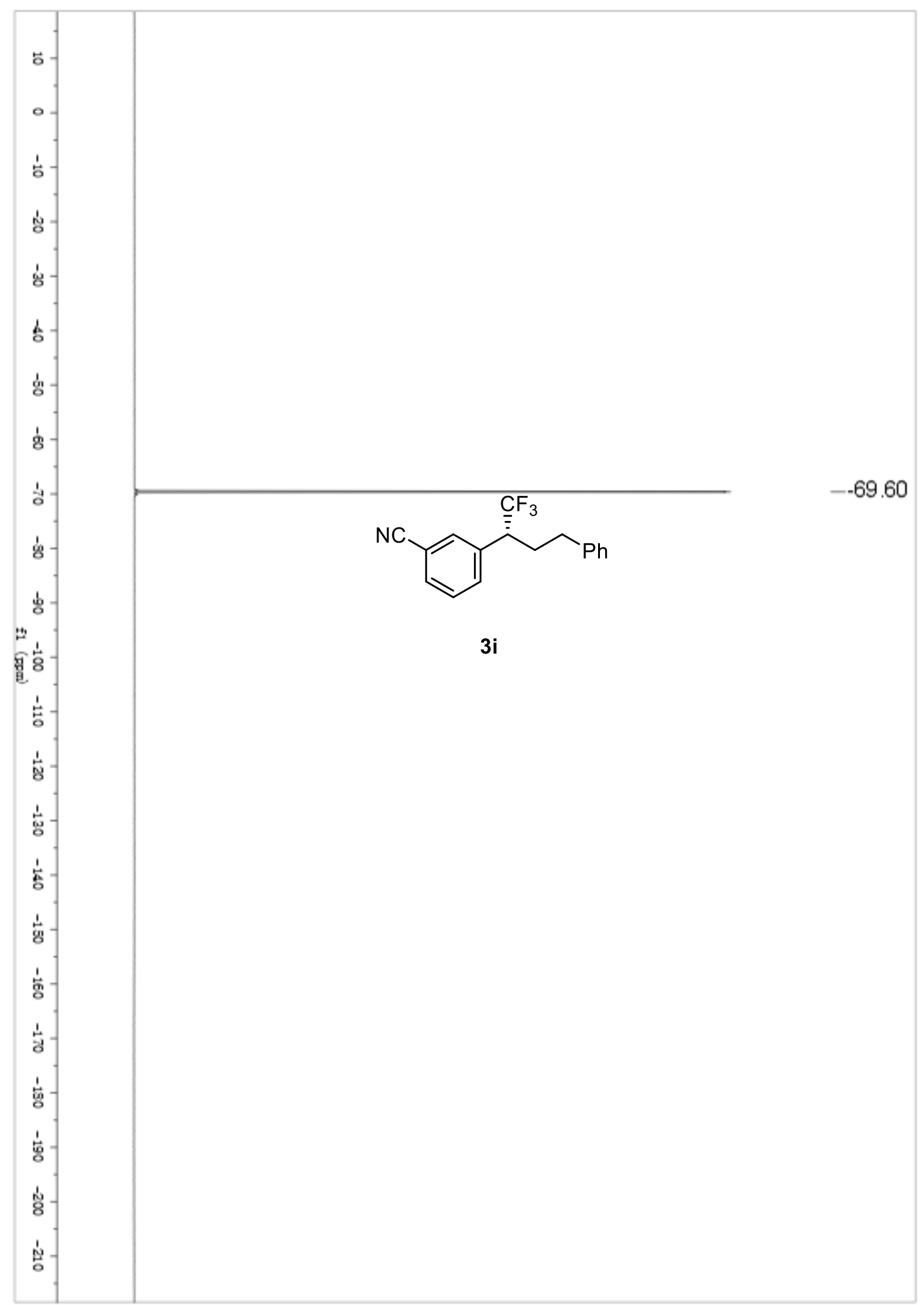


Compound 3j ${ }^{1} \mathrm{H}$ NMR (400 MHz, $\mathrm{CDCl}_{3}$ )

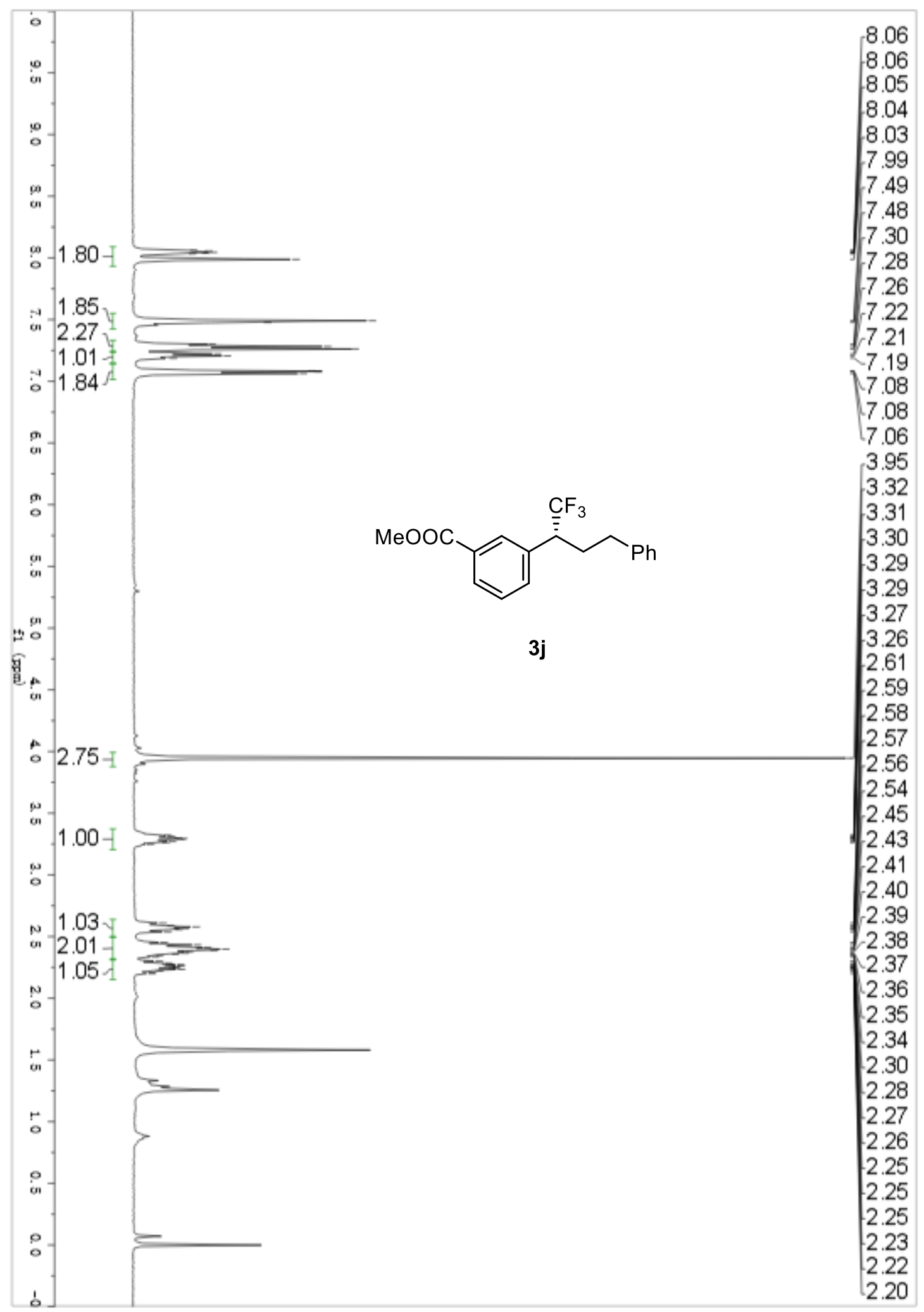


Compound 3k ${ }^{1} \mathrm{H}$ NMR (400 MHz, $\left.\mathrm{CDCl}_{3}\right)$

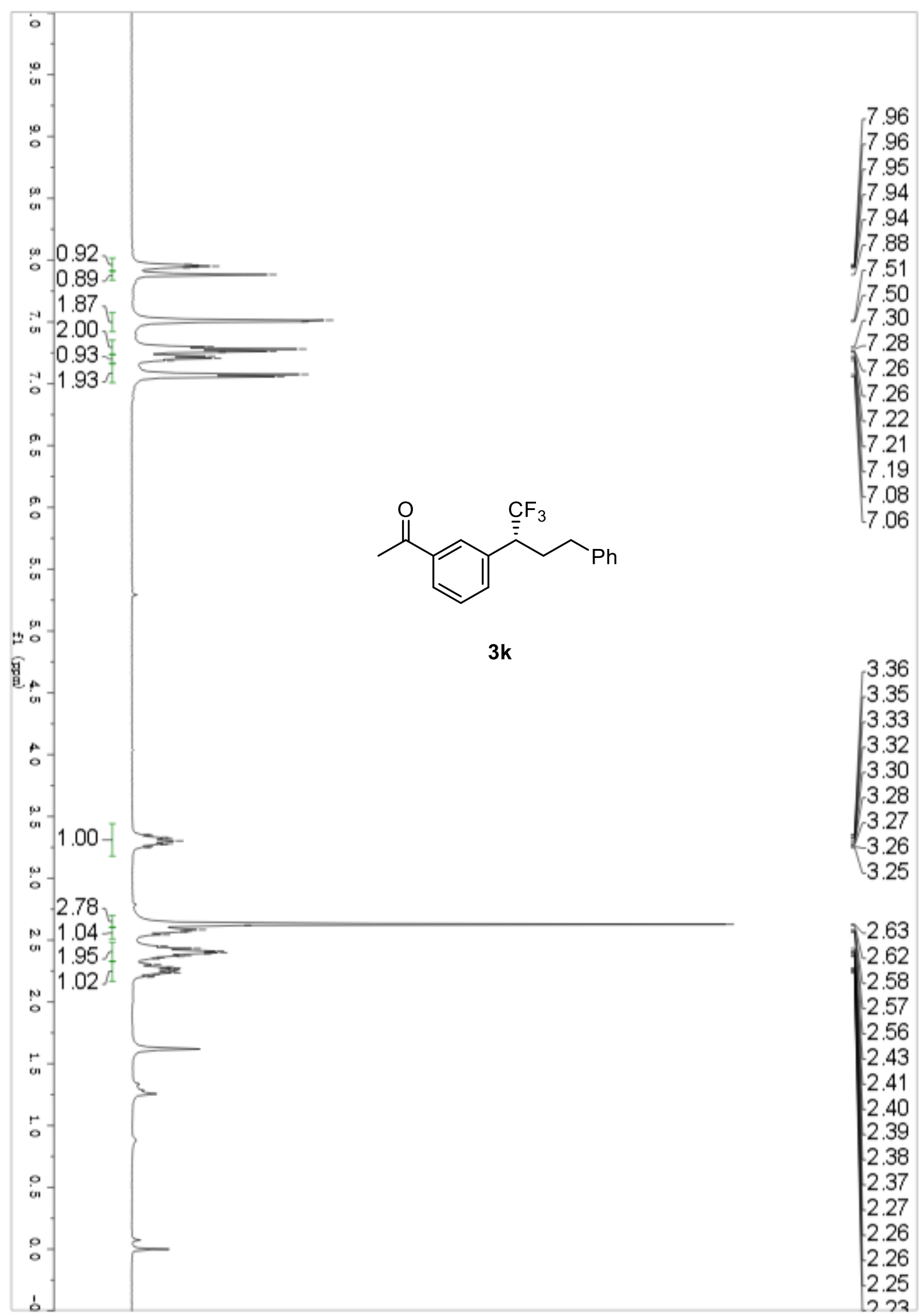


Compound $3 \mathrm{I}^{1} \mathrm{H}$ NMR (400 MHz, $\mathrm{CDCl}_{3}$ )

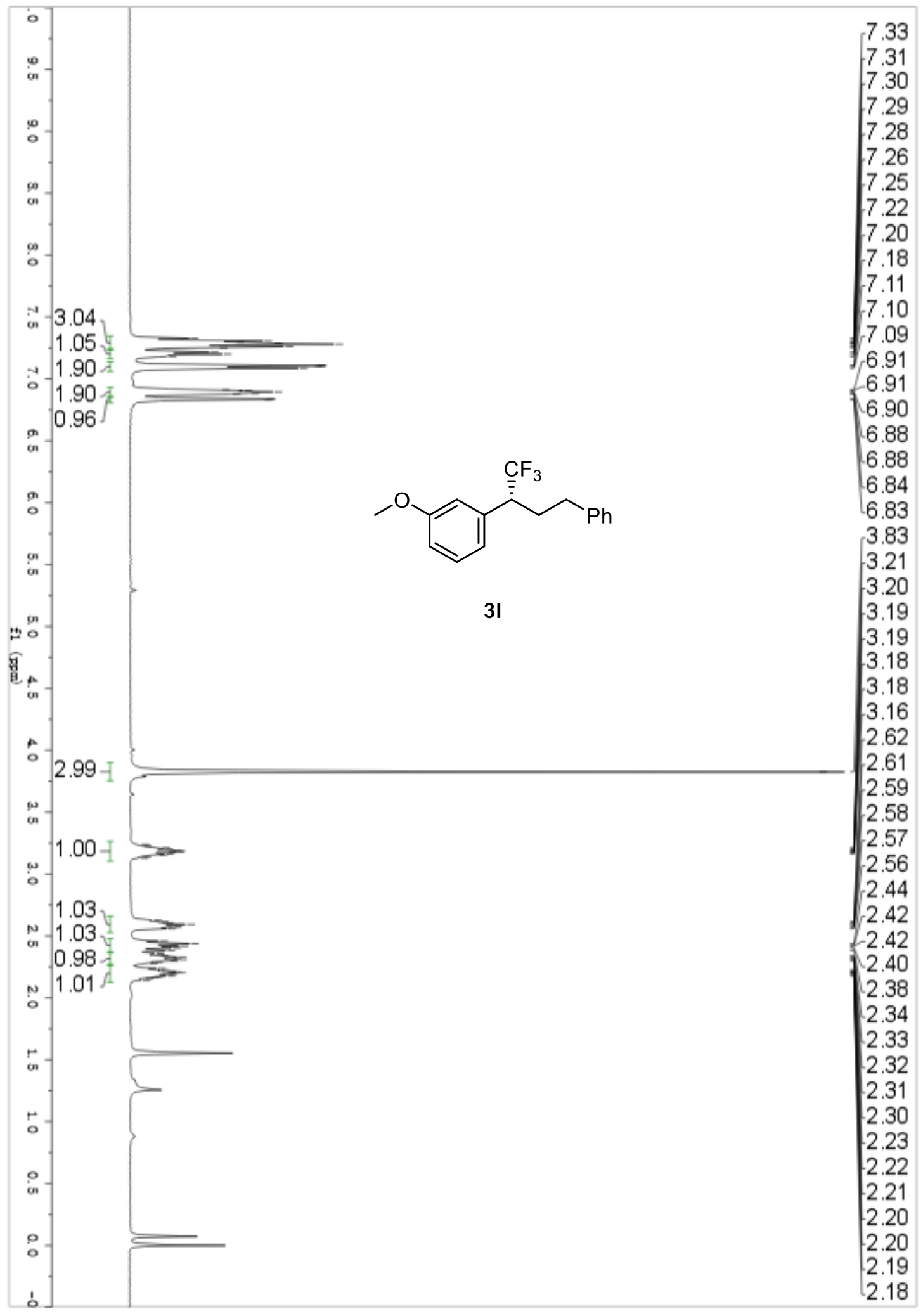


Compound 3m ${ }^{1} \mathrm{H}$ NMR (600 MHz, $\left.\mathrm{CDCl}_{3}\right)$

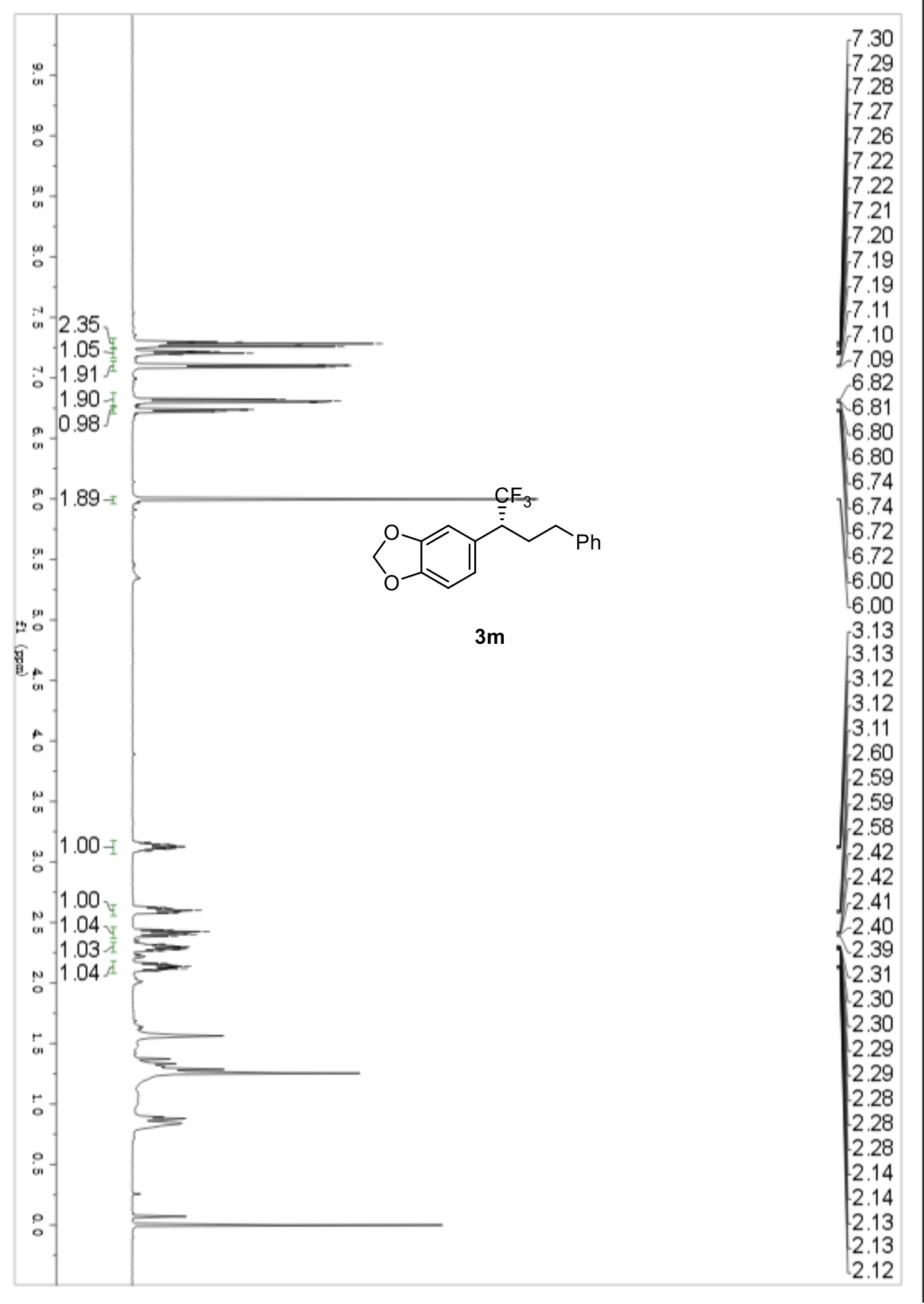


Compound 3m ${ }^{13} \mathrm{C}$ NMR (151 MHz, $\mathrm{CDCl}_{3}$ )

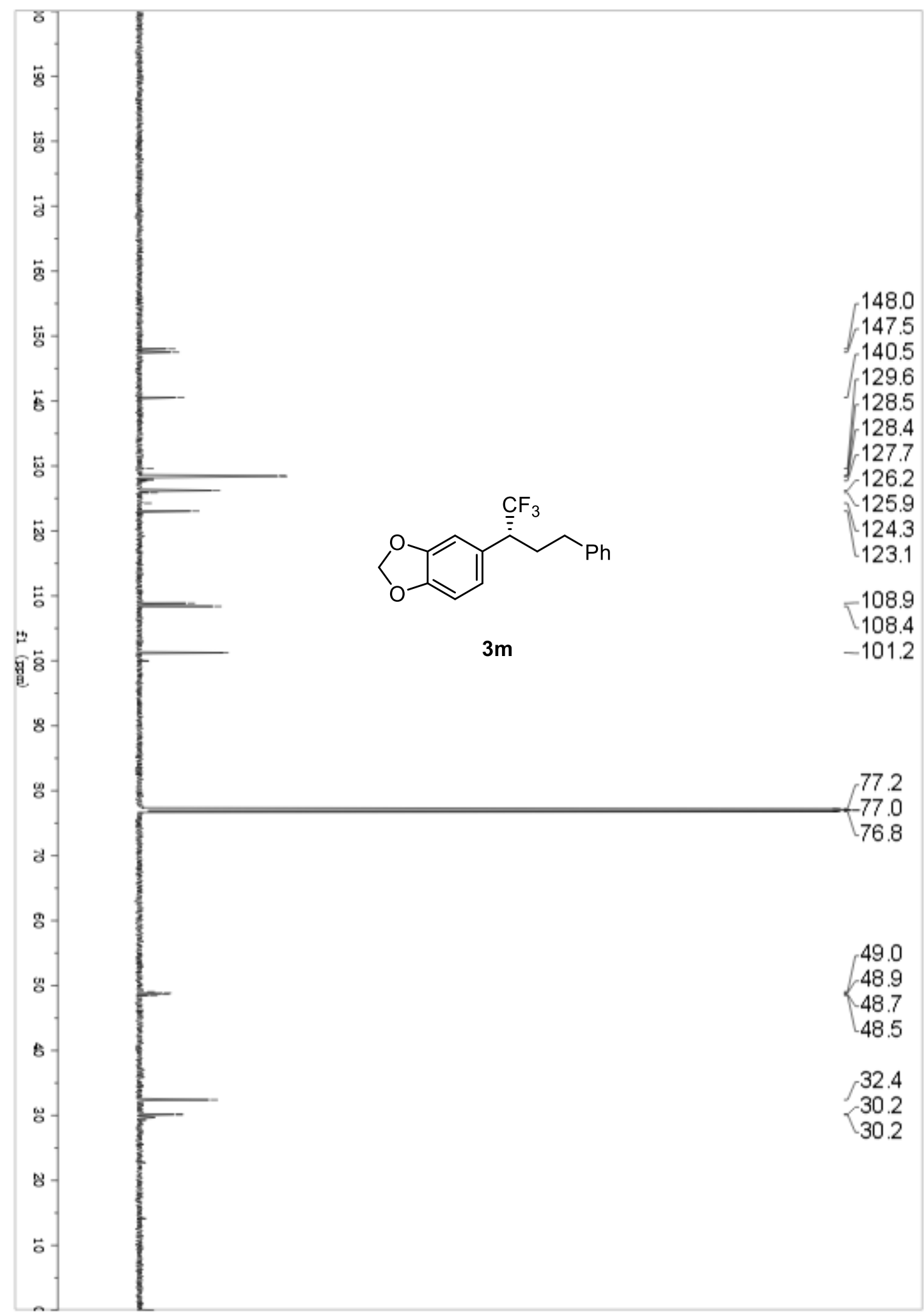


Compound 3m ${ }^{19} \mathrm{~F}$ NMR (565 MHz, $\left.\mathrm{CDCl}_{3}\right)$

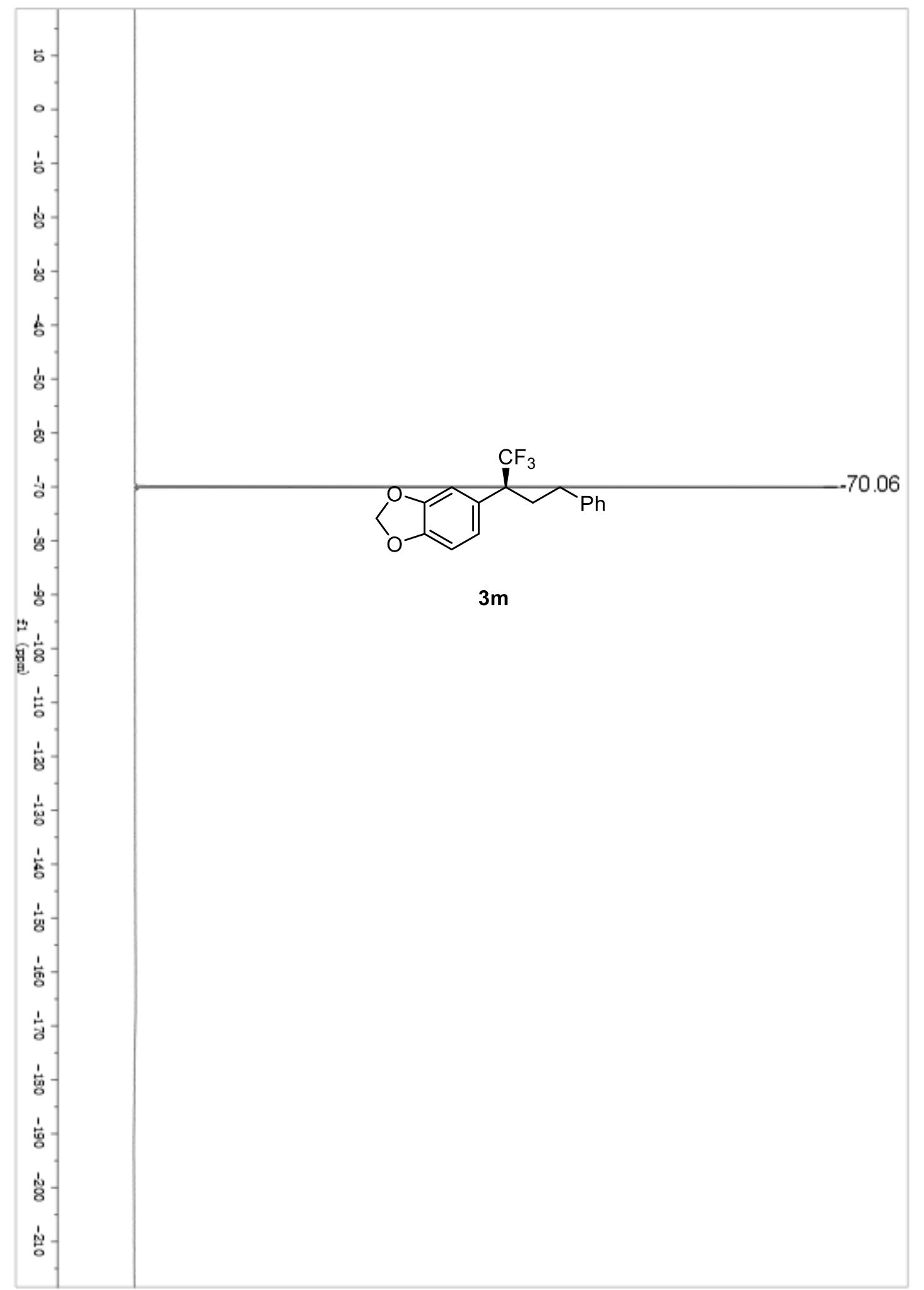


Compound 3n ${ }^{1} \mathrm{H}$ NMR (600 MHz, $\left.\mathrm{CDCl}_{3}\right)$

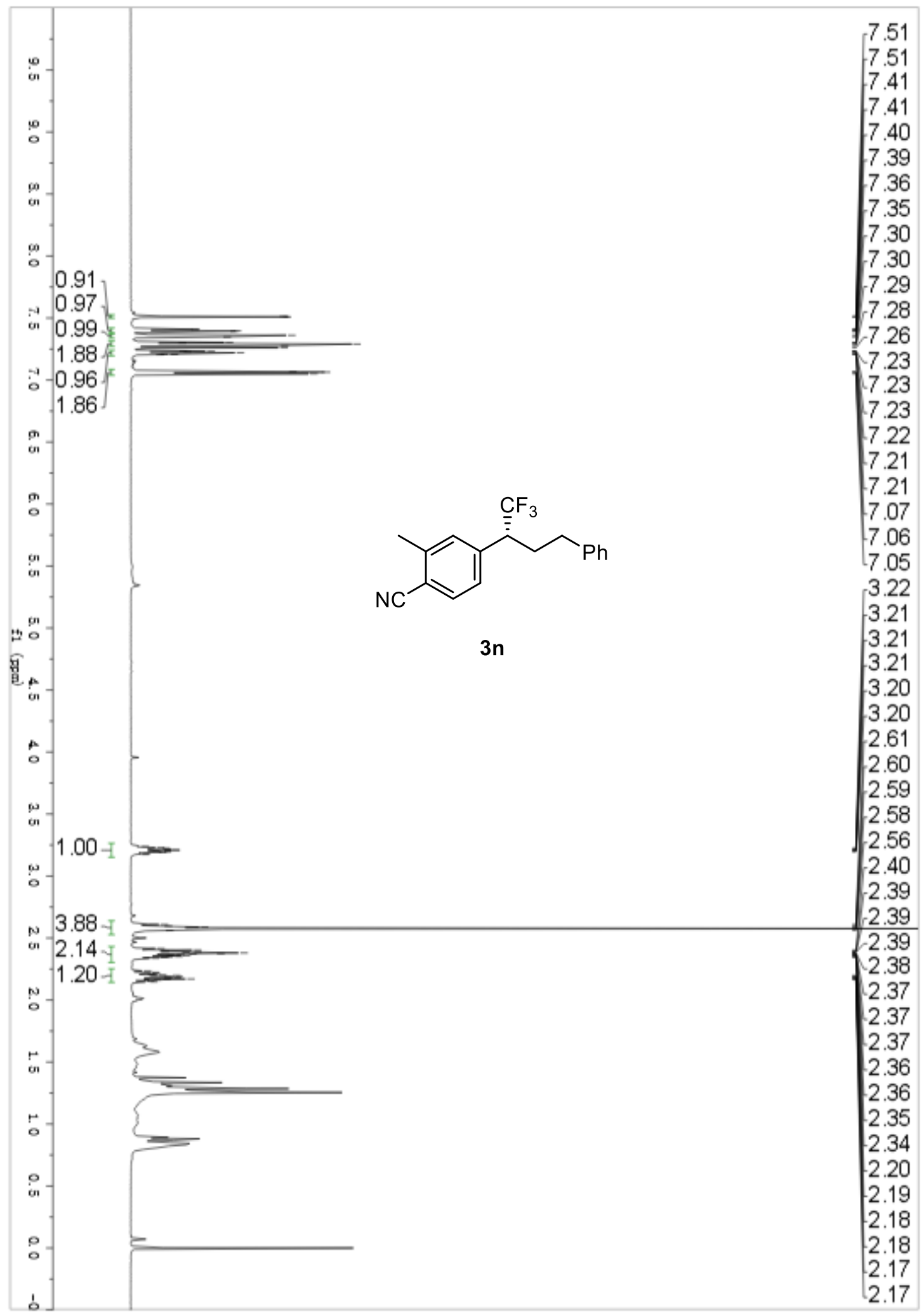


Compound 3n ${ }^{13} \mathrm{C}$ NMR (151 MHz, $\mathrm{CDCl}_{3}$ )

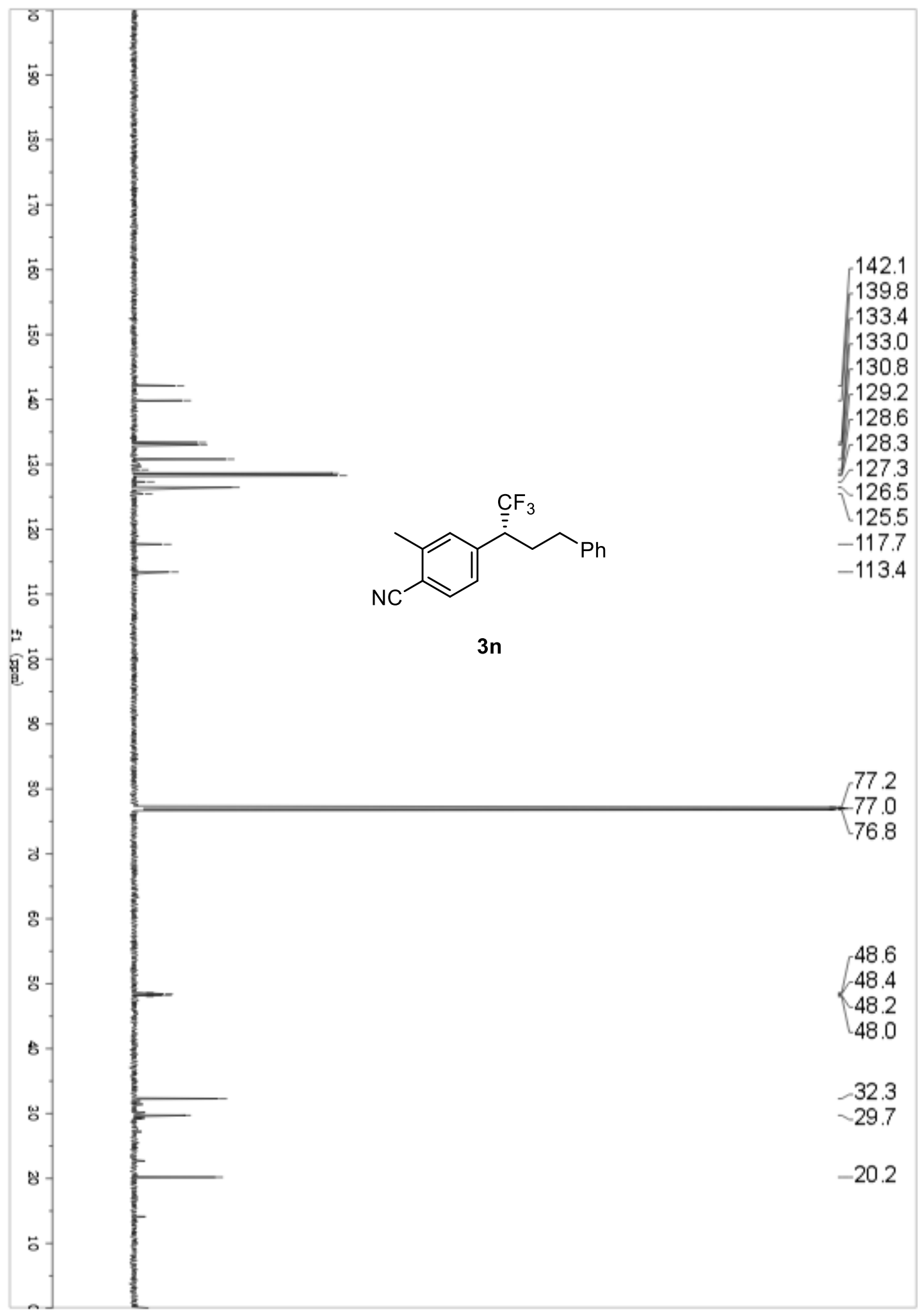


Compound 3n ${ }^{19} \mathrm{~F}$ NMR (565 MHz, $\mathrm{CDCl}_{3}$ )

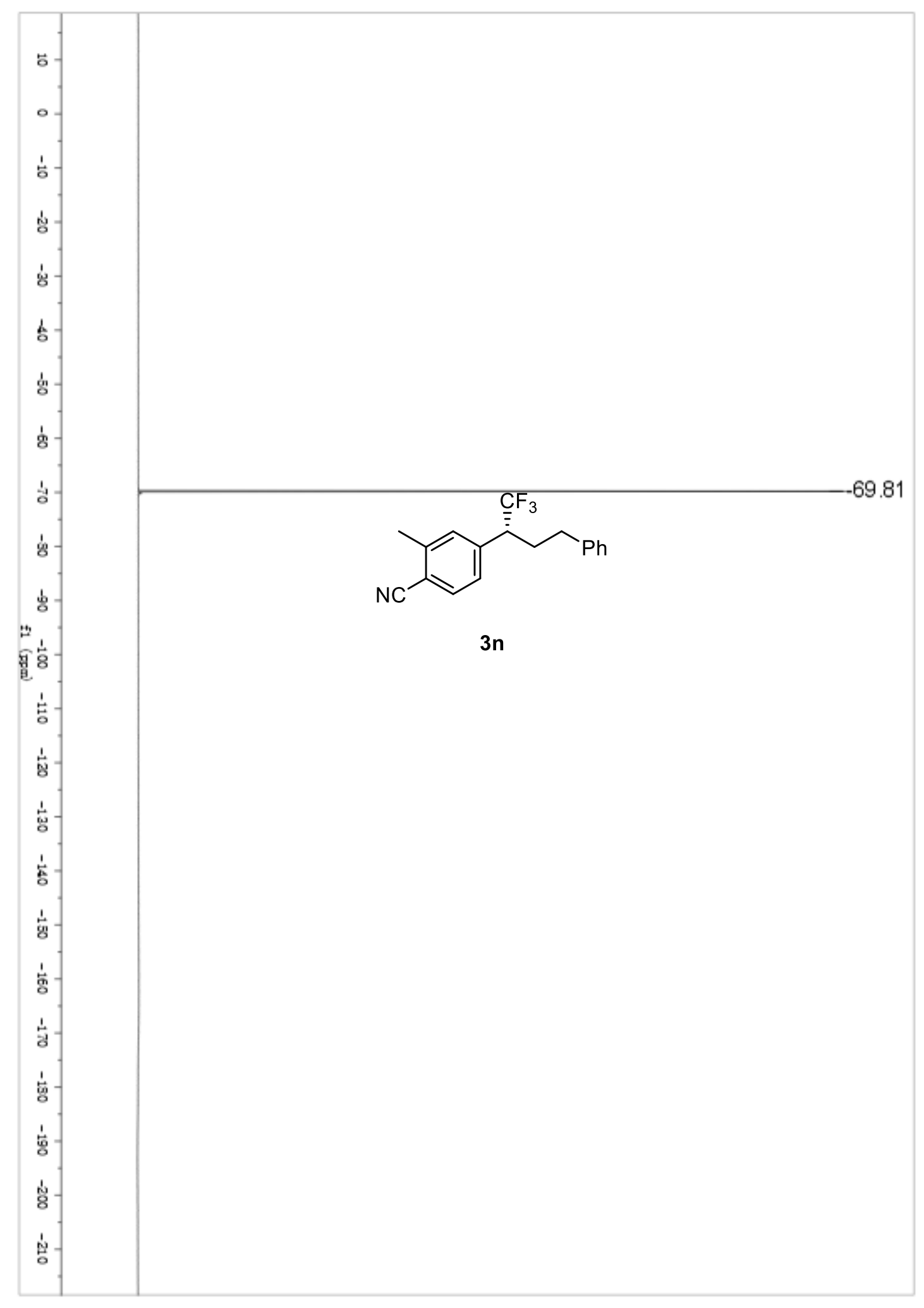


Compound 3o ${ }^{1} \mathrm{H}$ NMR $\left(600 \mathrm{MHz}, \mathrm{CDCl}_{3}\right)$

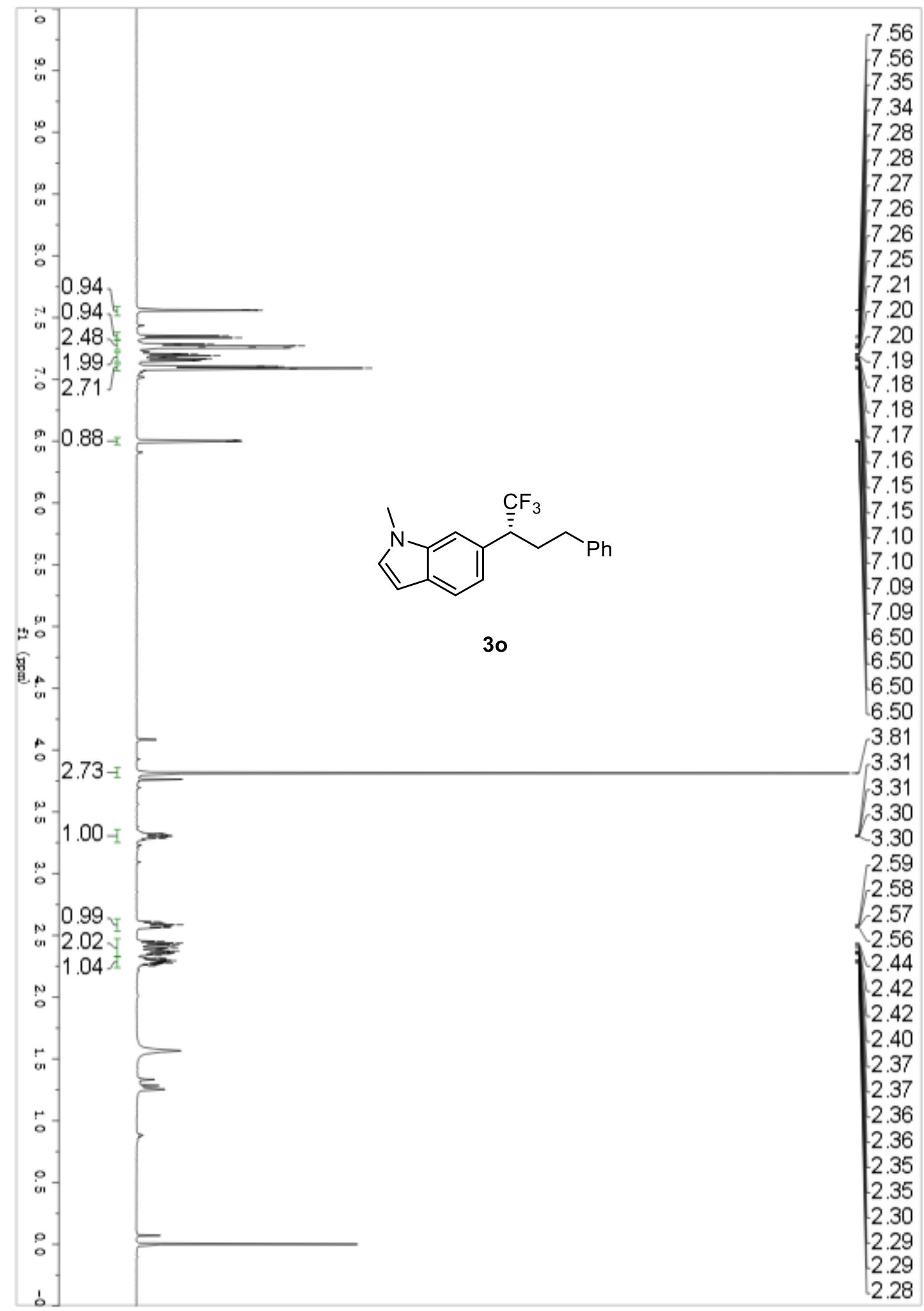


Compound 3p ${ }^{1} \mathrm{H}$ NMR (600 MHz, $\left.\mathrm{CDCl}_{3}\right)$

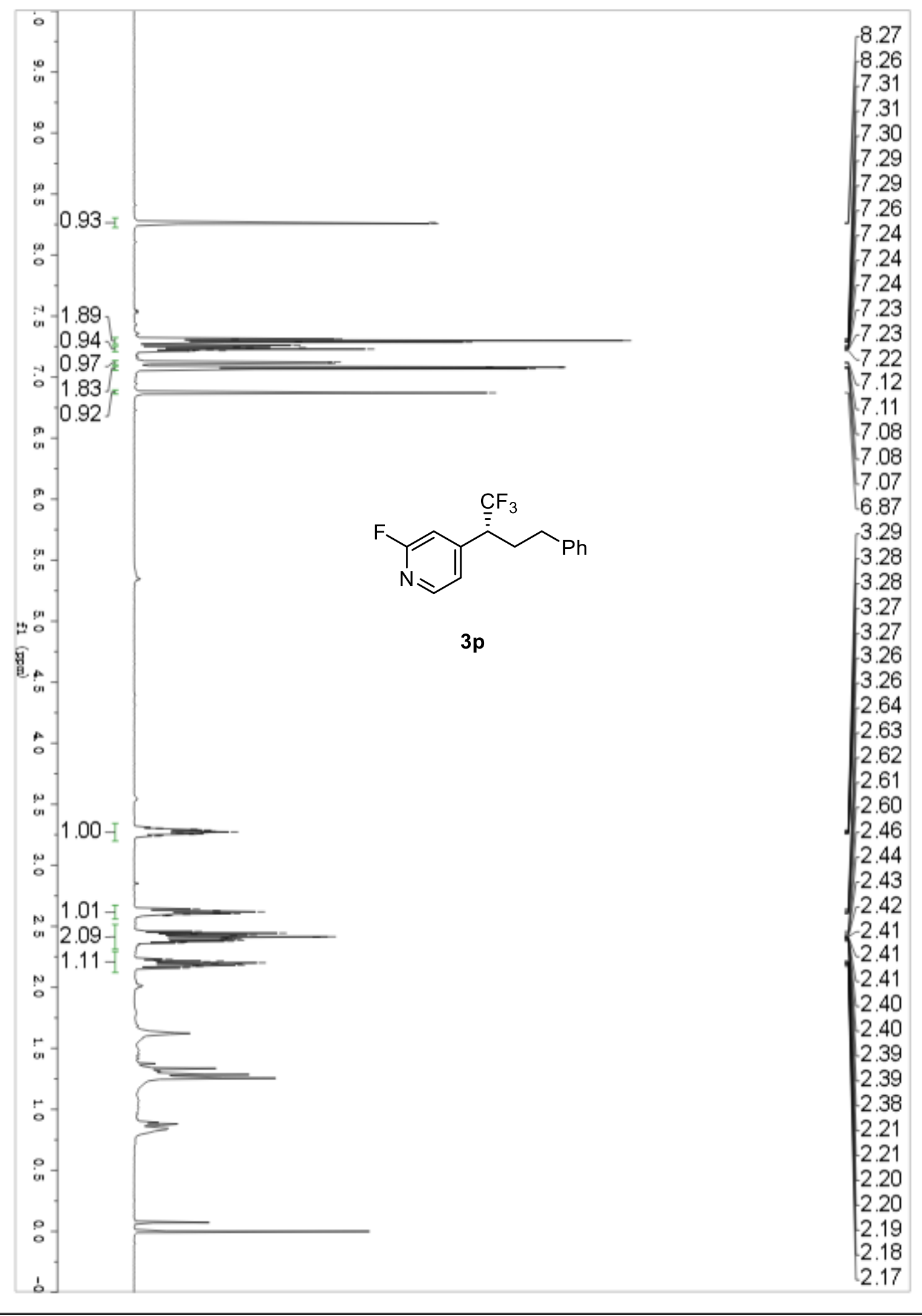


Compound 3p ${ }^{13} \mathrm{C}$ NMR (151 MHz, $\mathrm{CDCl}_{3}$ )

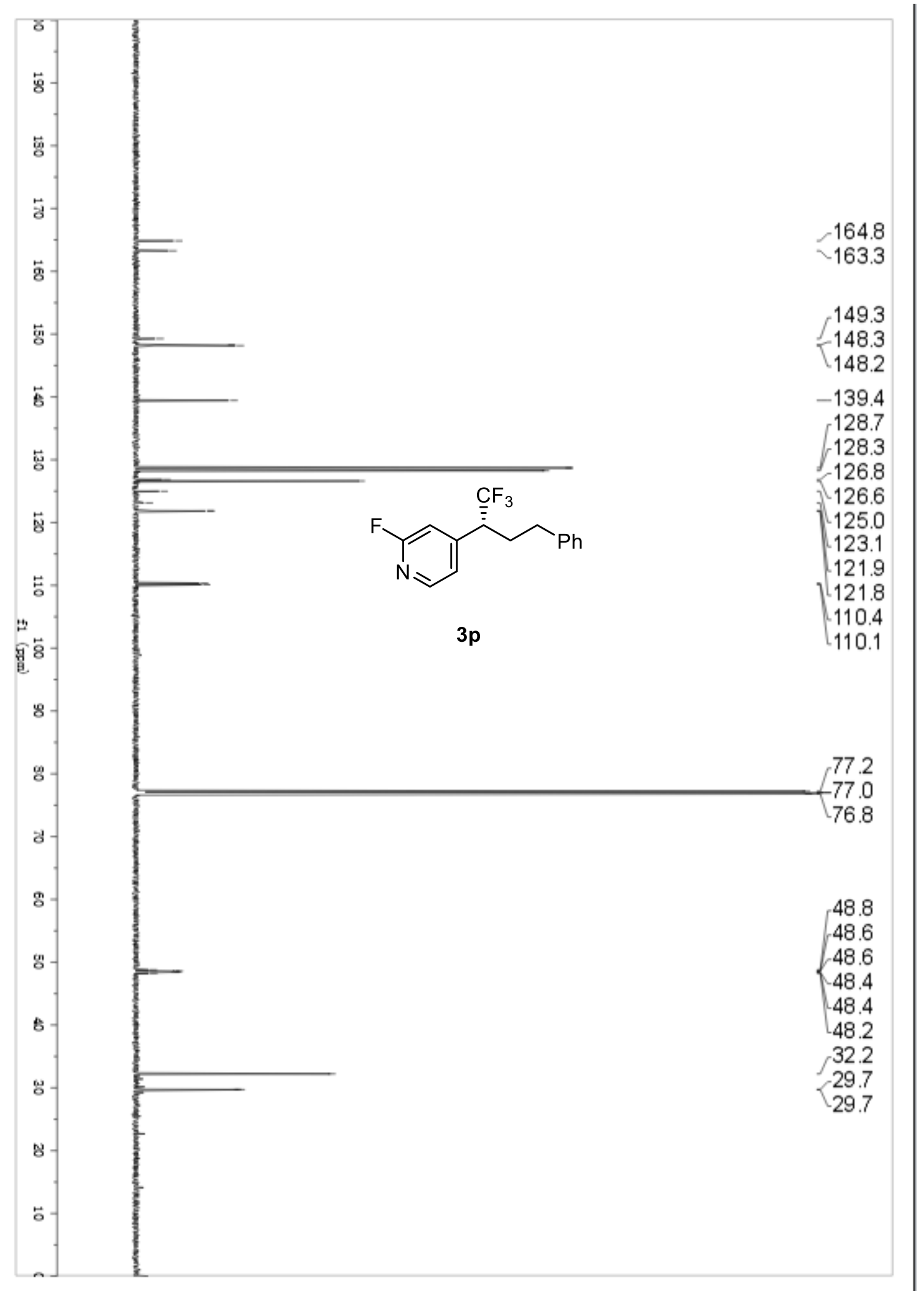


Compound 3p ${ }^{19} \mathrm{~F}$ NMR (565 MHz, $\mathrm{CDCl}_{3}$ )

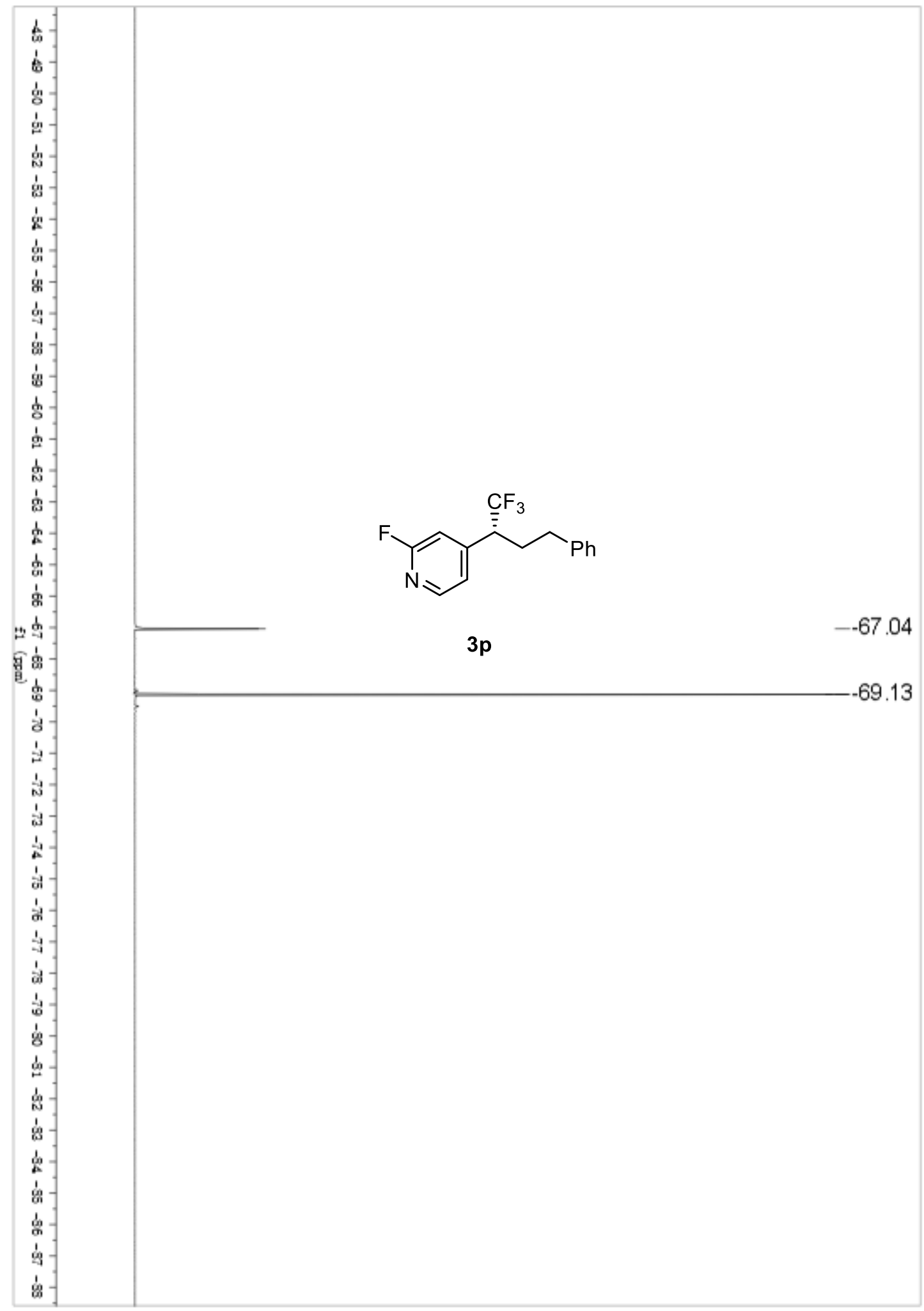


Compound 3q ${ }^{1} \mathrm{H}$ NMR $\left(600 \mathrm{MHz}, \mathrm{CDCl}_{3}\right)$

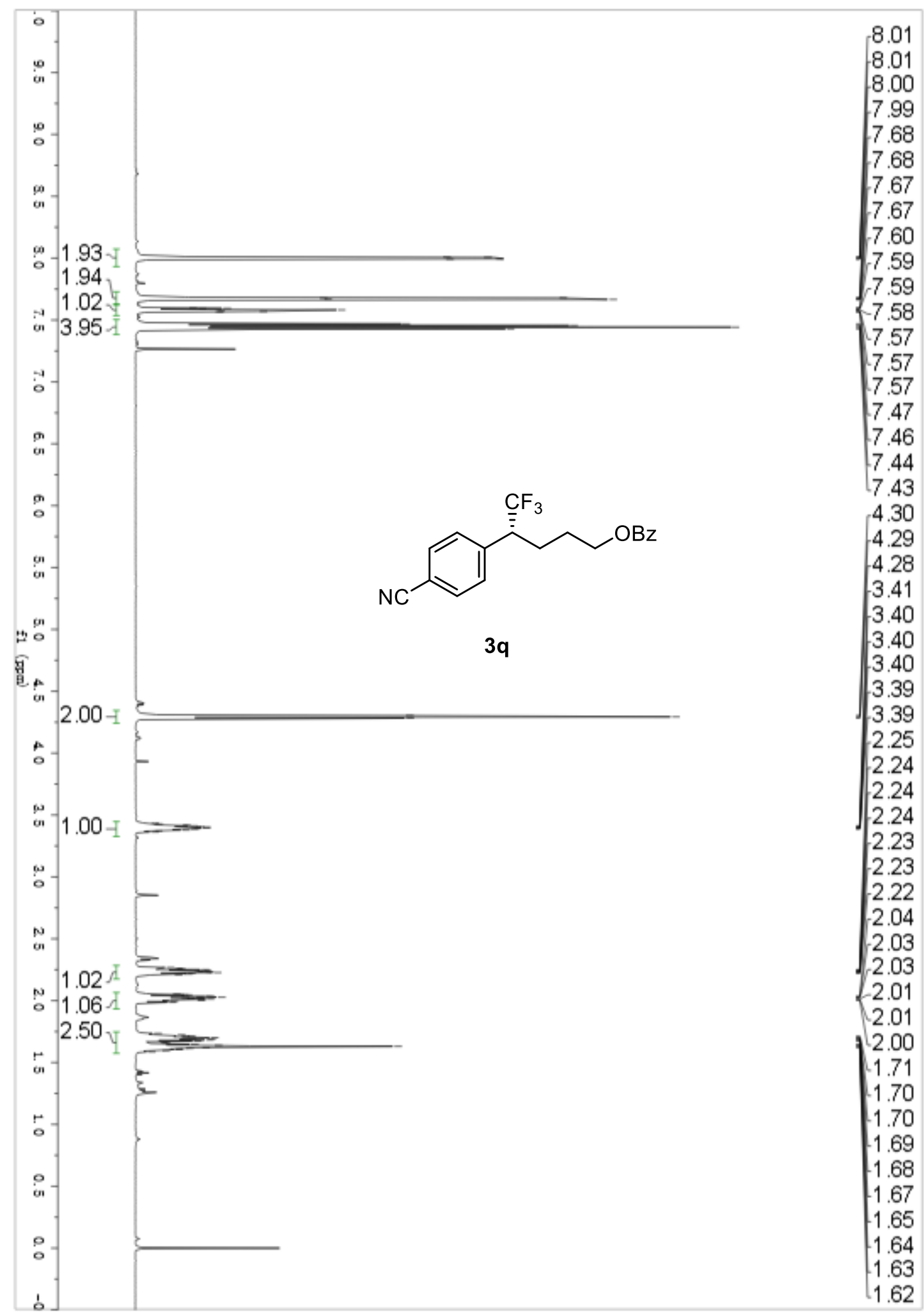


Compound 3q ${ }^{13} \mathrm{C}$ NMR (151 MHz, $\mathrm{CDCl}_{3}$ )

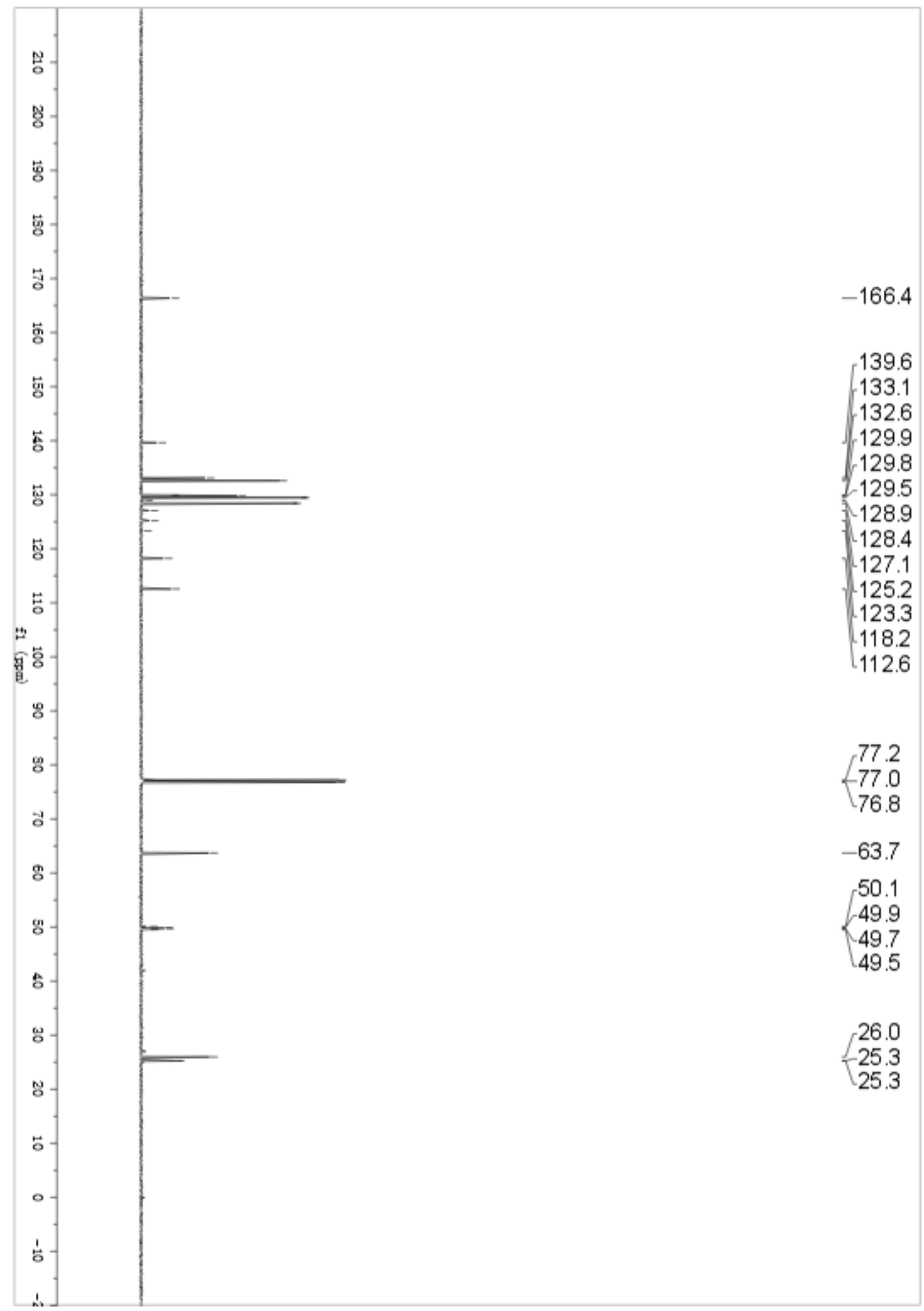


Compound 3q ${ }^{19} \mathrm{~F}$ NMR (565 MHz, $\mathrm{CDCl}_{3}$ )

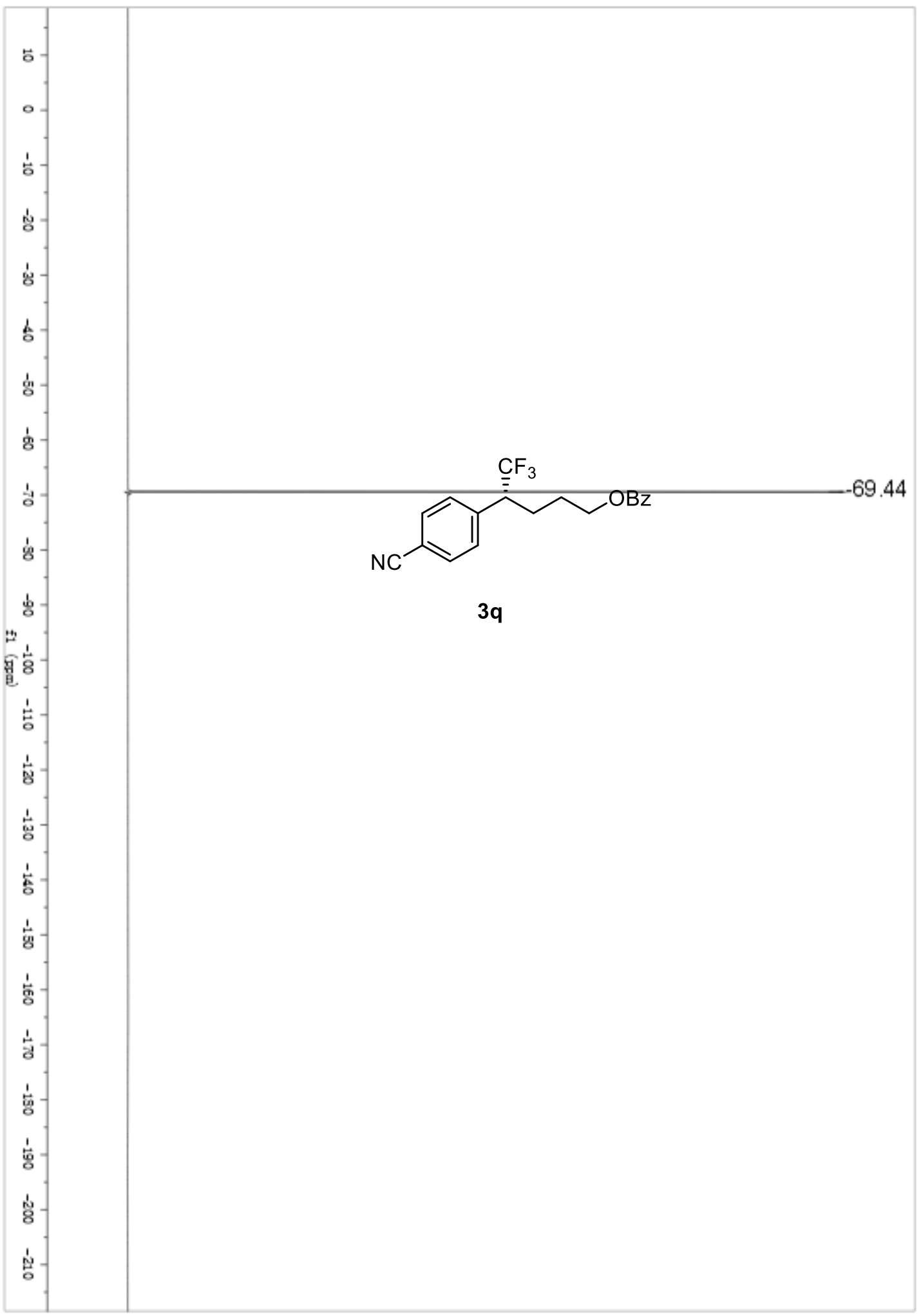


Compound $3 \mathbf{r}^{1} \mathrm{H}$ NMR $\left(600 \mathrm{MHz}, \mathrm{CDCl}_{3}\right)$

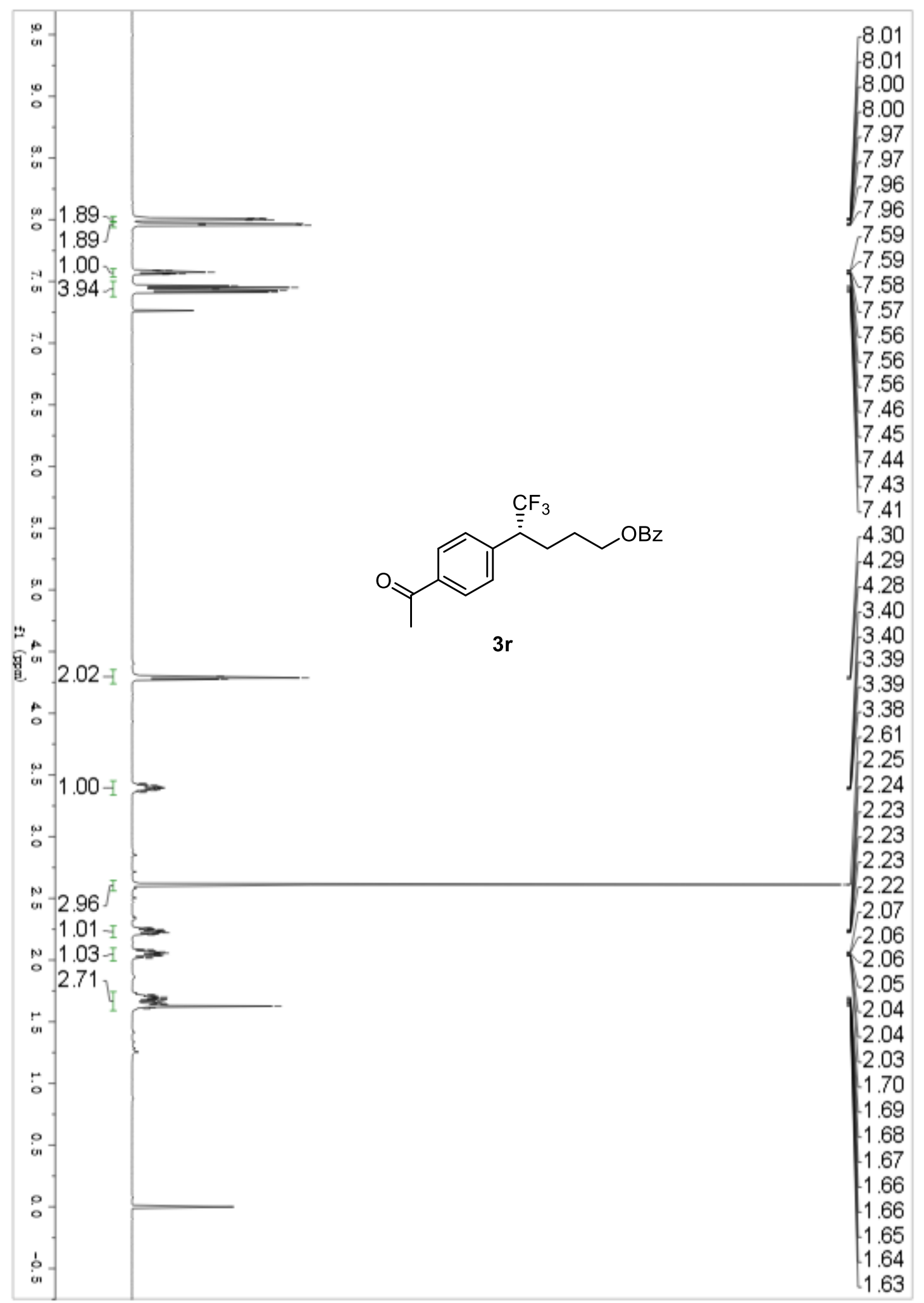


Compound 3s ${ }^{1} \mathrm{H}$ NMR (600 MHz, $\left.\mathrm{CDCl}_{3}\right)$

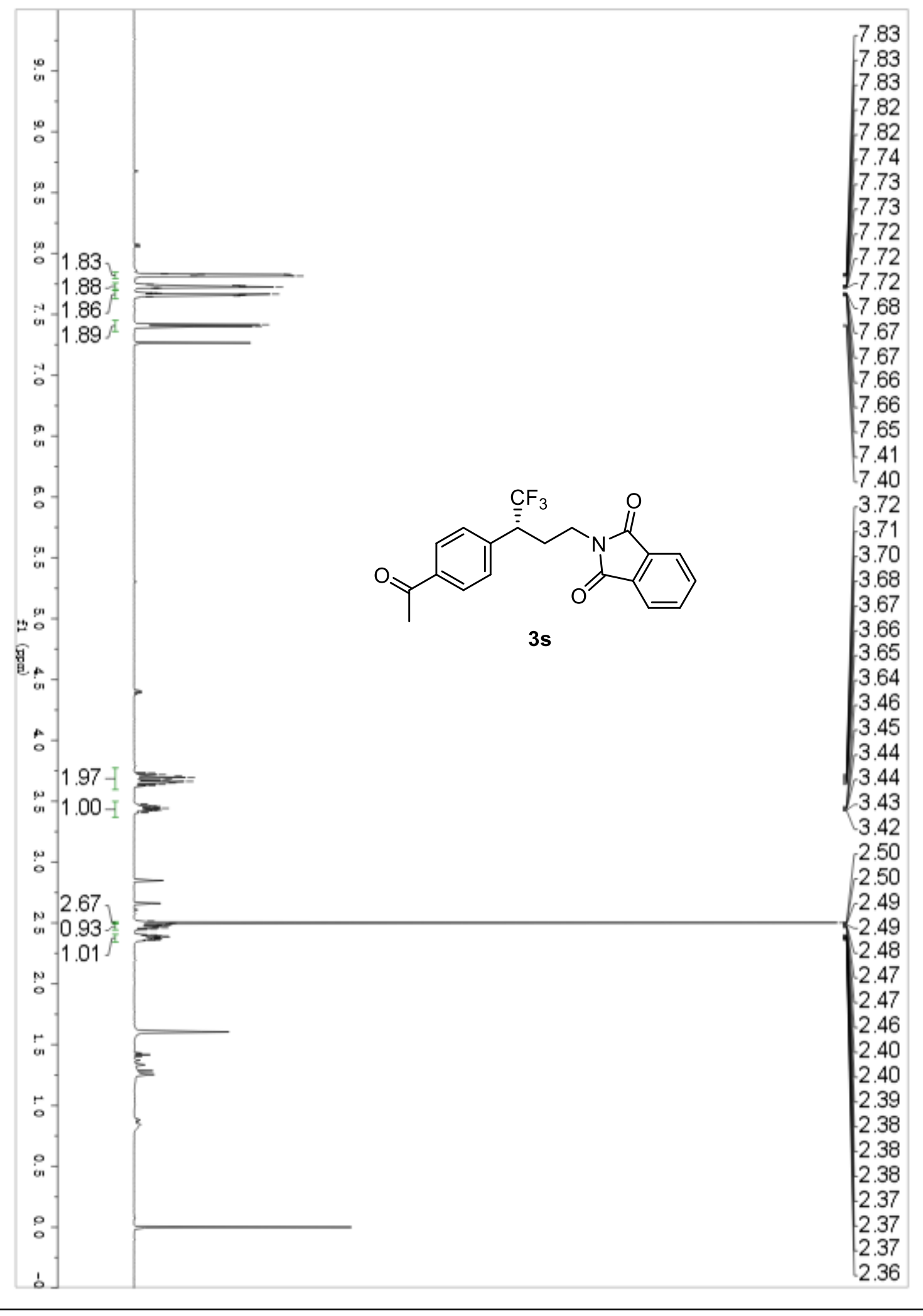


Compound 3s ${ }^{13} \mathrm{C}$ NMR (151 MHz, $\mathrm{CDCl}_{3}$ )

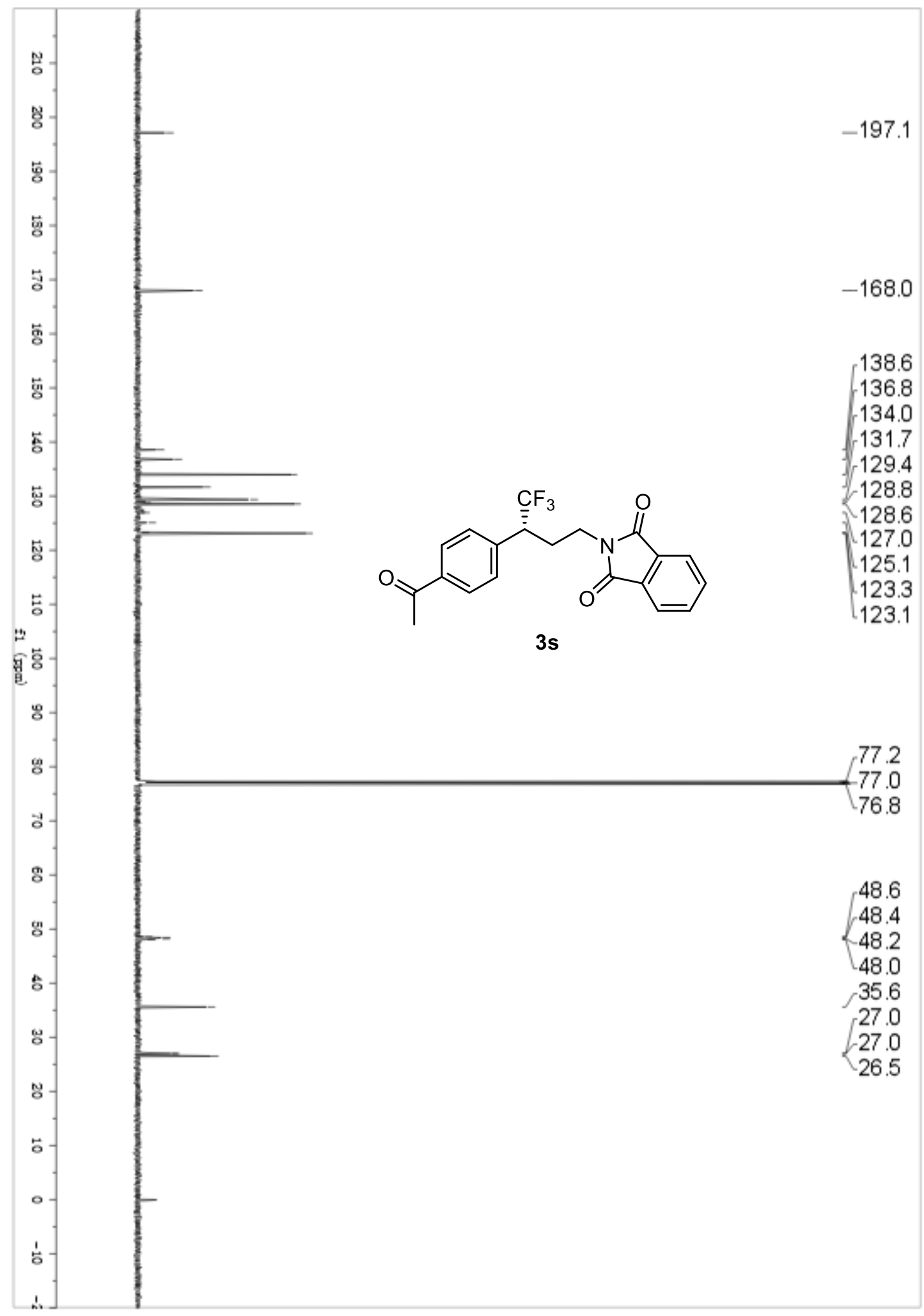


Compound 3s ${ }^{19} \mathrm{~F}$ NMR (565 MHz, $\left.\mathrm{CDCl}_{3}\right)$

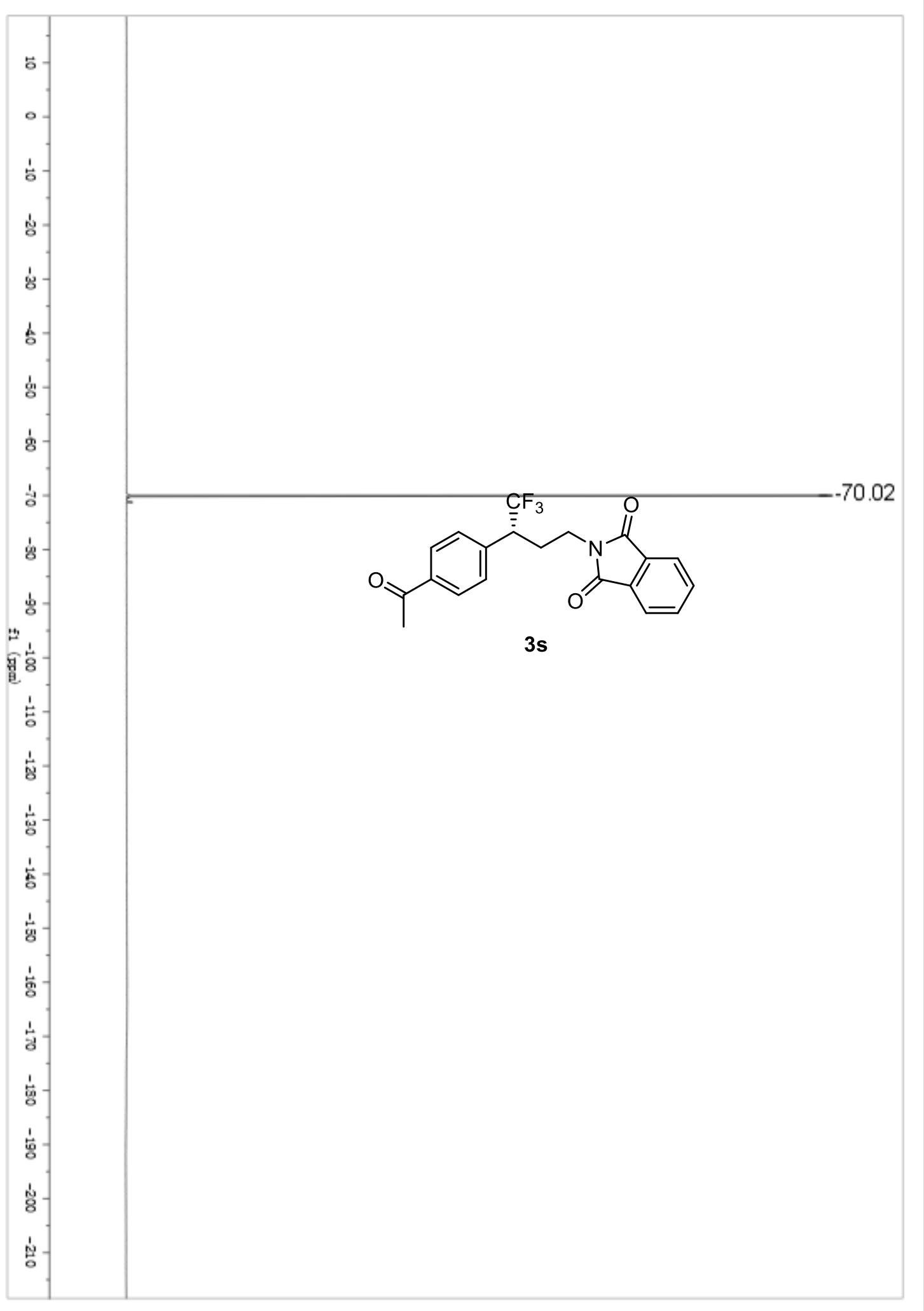


Compound $3 \mathbf{t}^{1} \mathrm{H}$ NMR (600 MHz, $\mathrm{CDCl}_{3}$ )

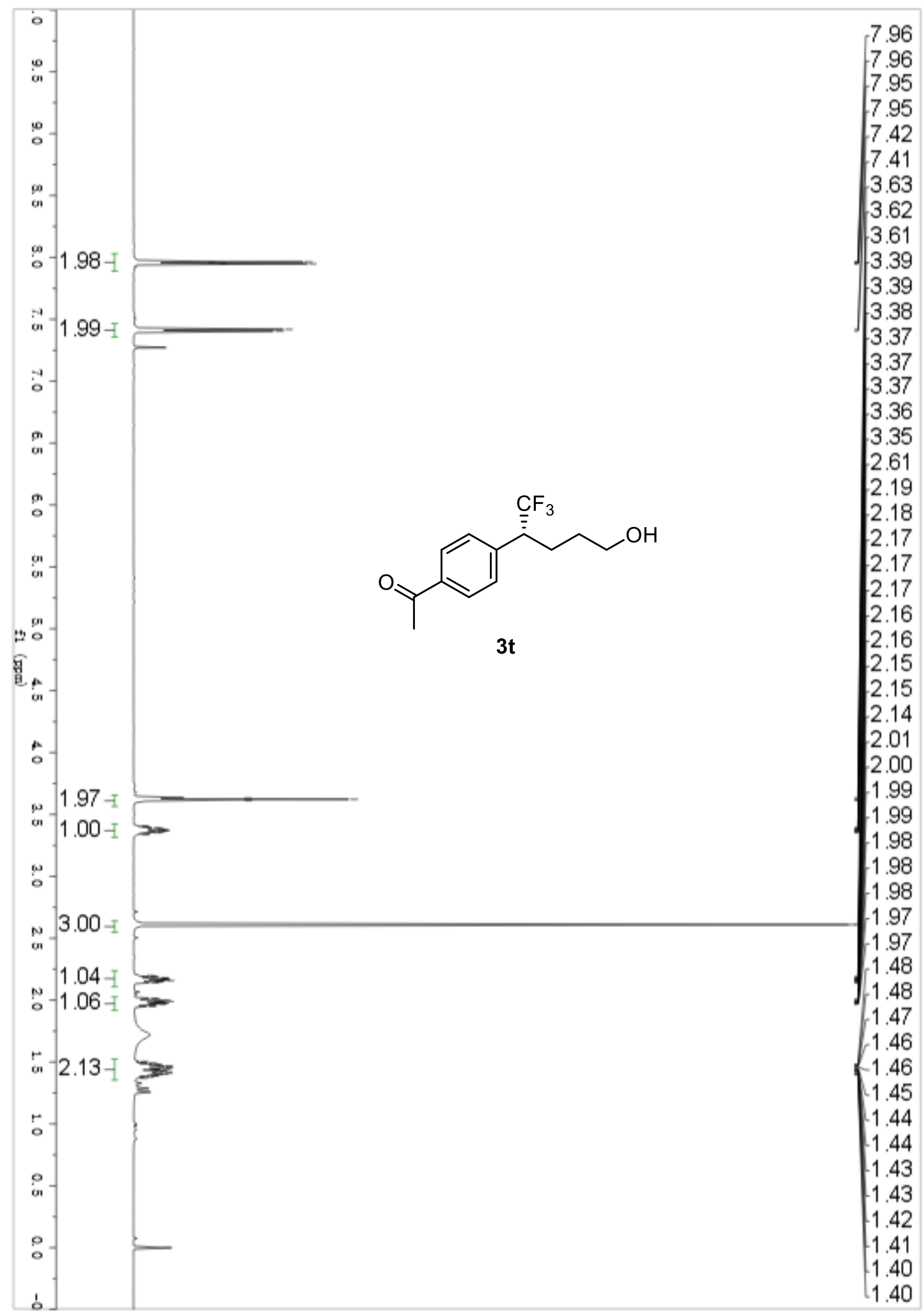


Compound 3u ${ }^{1} \mathrm{H}$ NMR $\left(600 \mathrm{MHz}, \mathrm{CDCl}_{3}\right)$

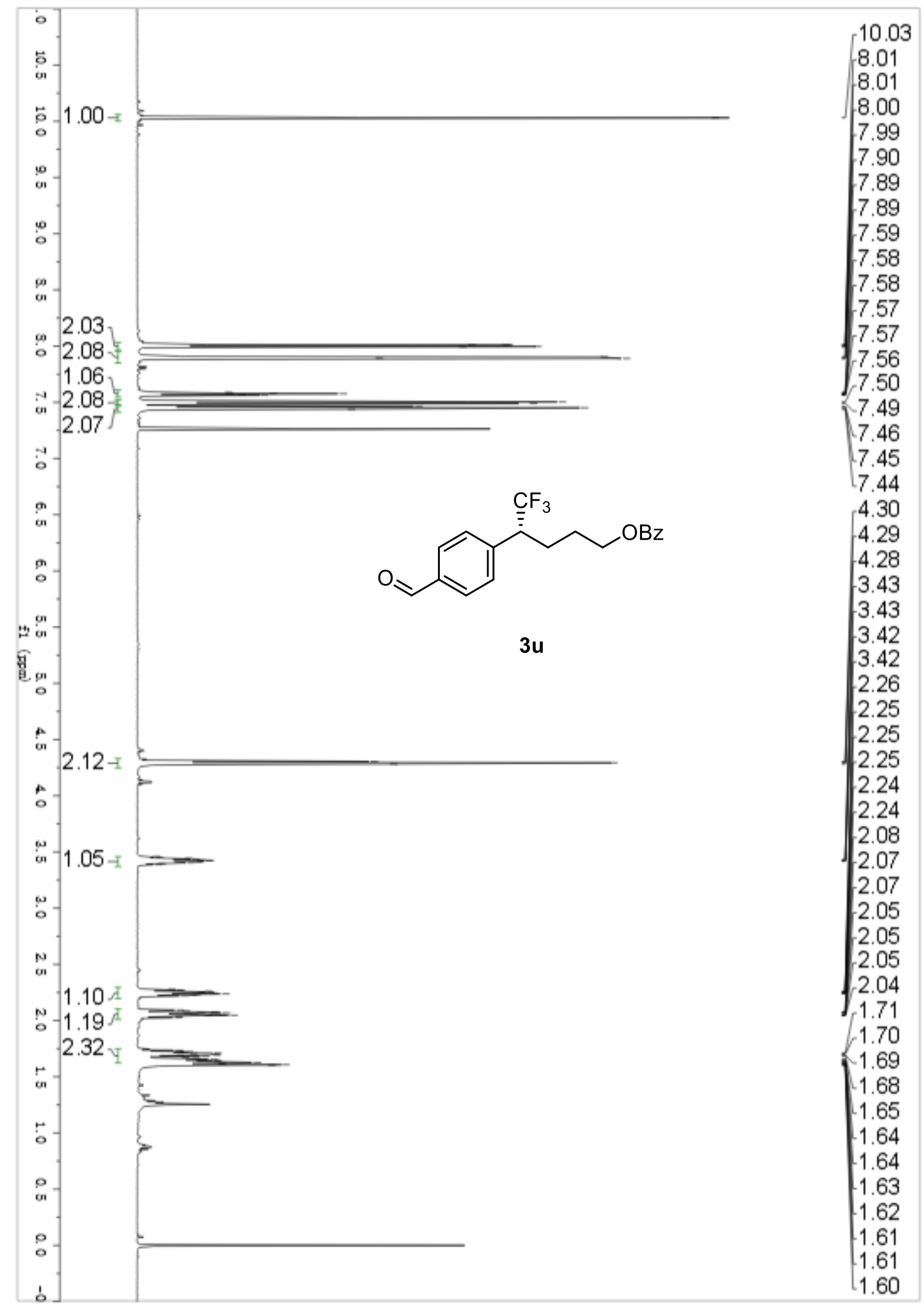


Compound 3v ${ }^{1} \mathrm{H}$ NMR (600 MHz, $\left.\mathrm{CDCl}_{3}\right)$

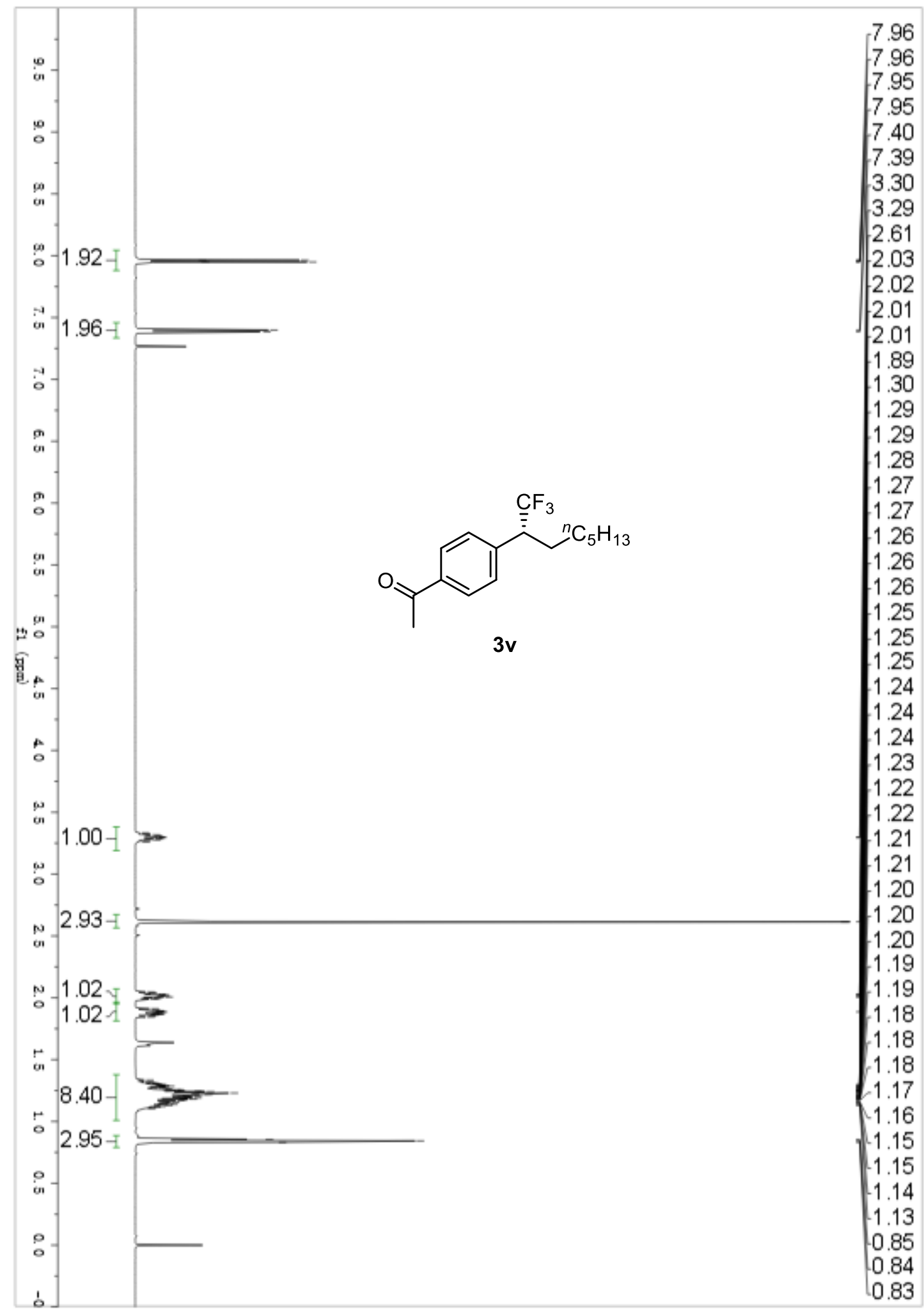


Compound 3w ${ }^{1} \mathrm{H}$ NMR (600 MHz, $\left.\mathrm{CDCl}_{3}\right)$

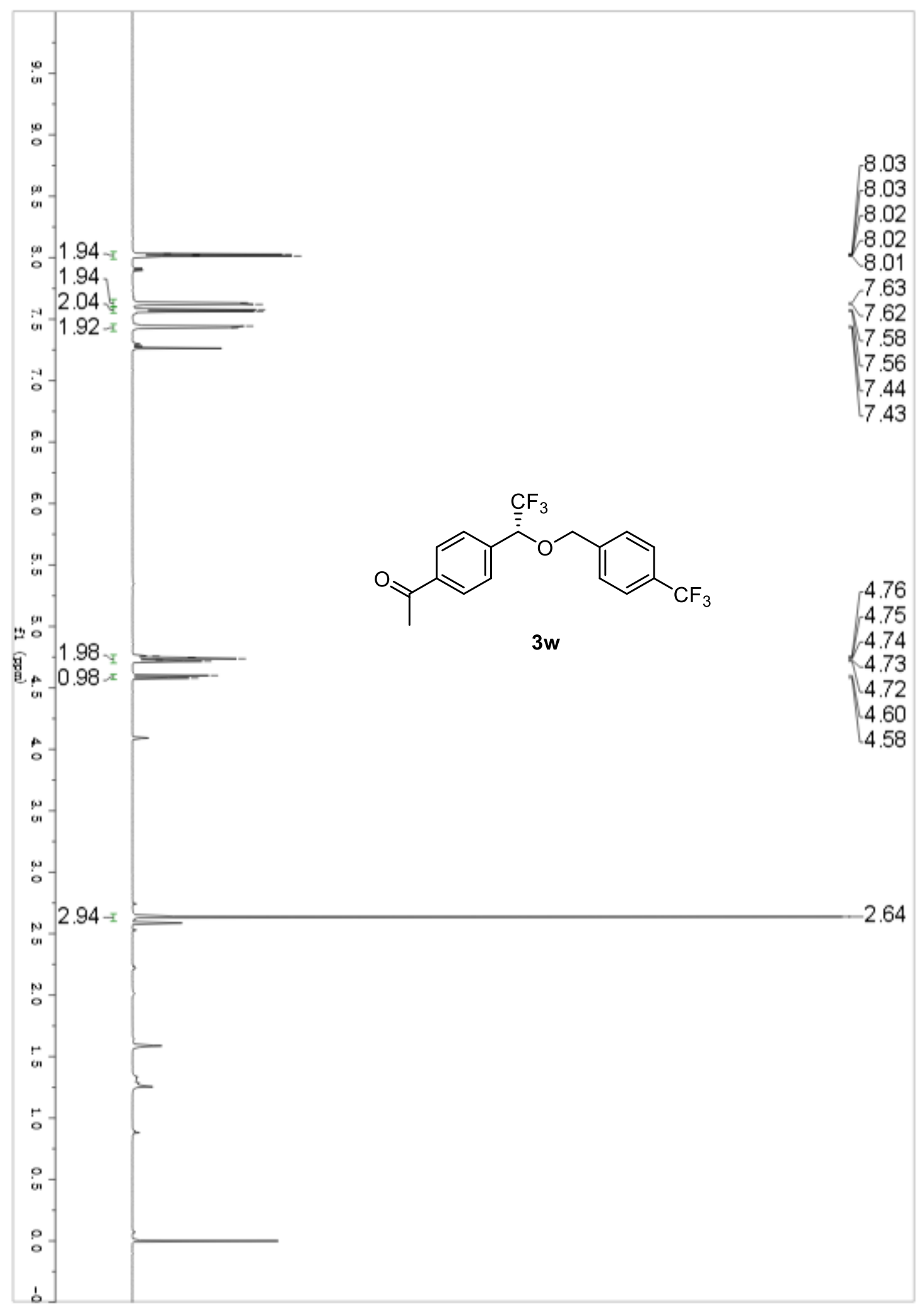


Compound 3w ${ }^{13} \mathrm{C}$ NMR (151 MHz, $\left.\mathrm{CDCl}_{3}\right)$

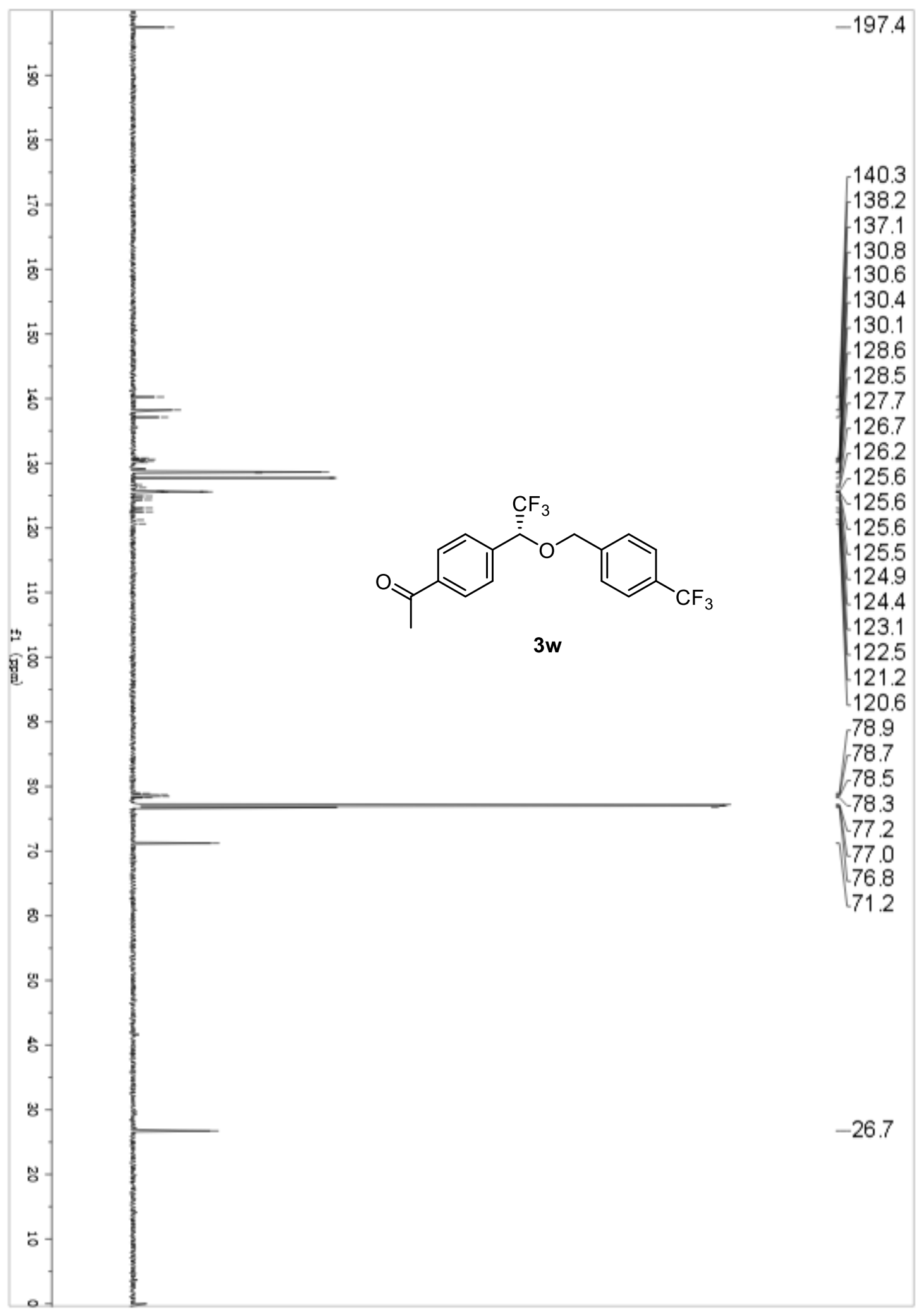


Compound 3w ${ }^{19} \mathrm{~F}$ NMR (565 MHz, $\mathrm{CDCl}_{3}$ )

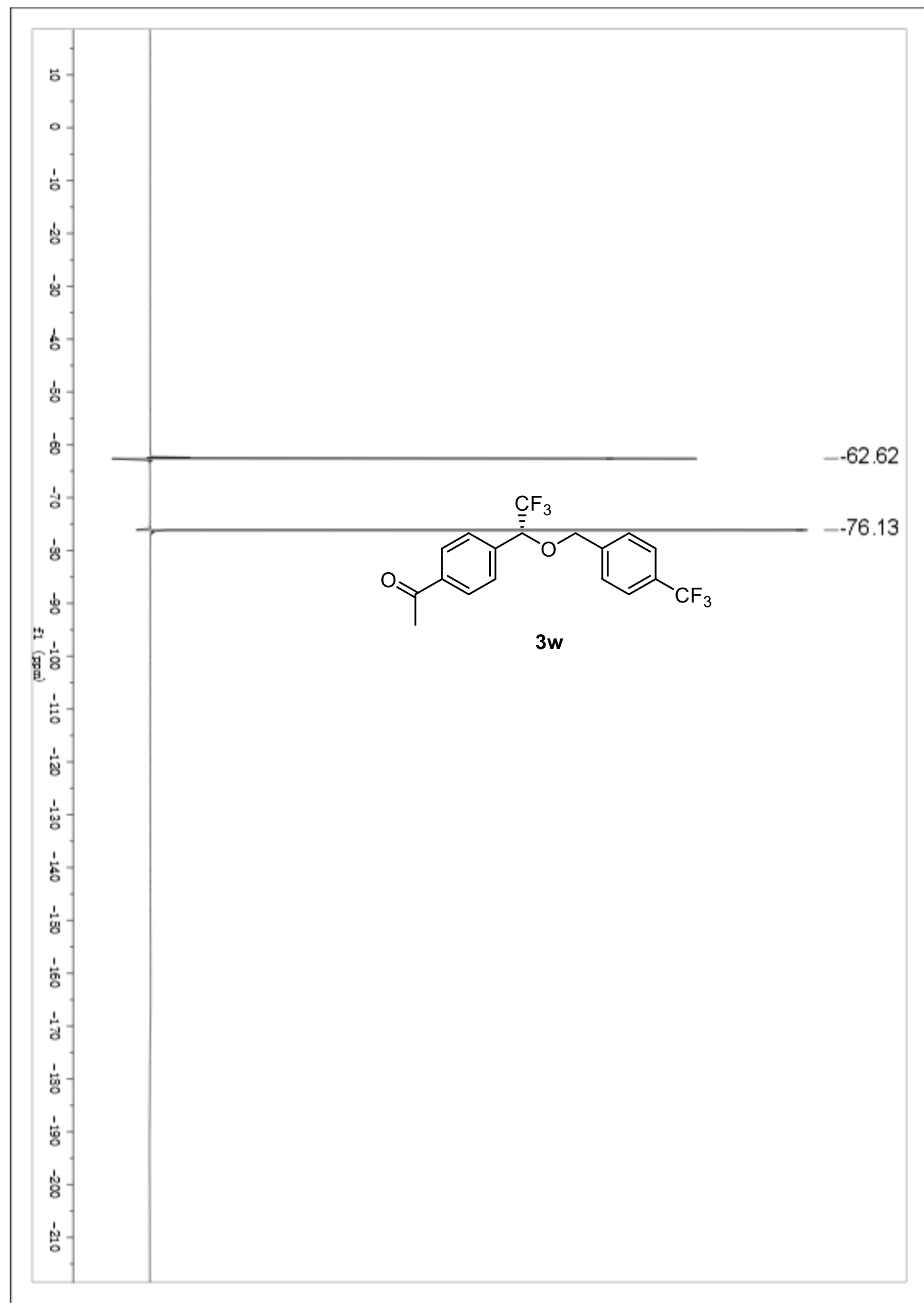


Compound 3x ${ }^{1} \mathrm{H}$ NMR (600 MHz, $\left.\mathrm{CDCl}_{3}\right)$

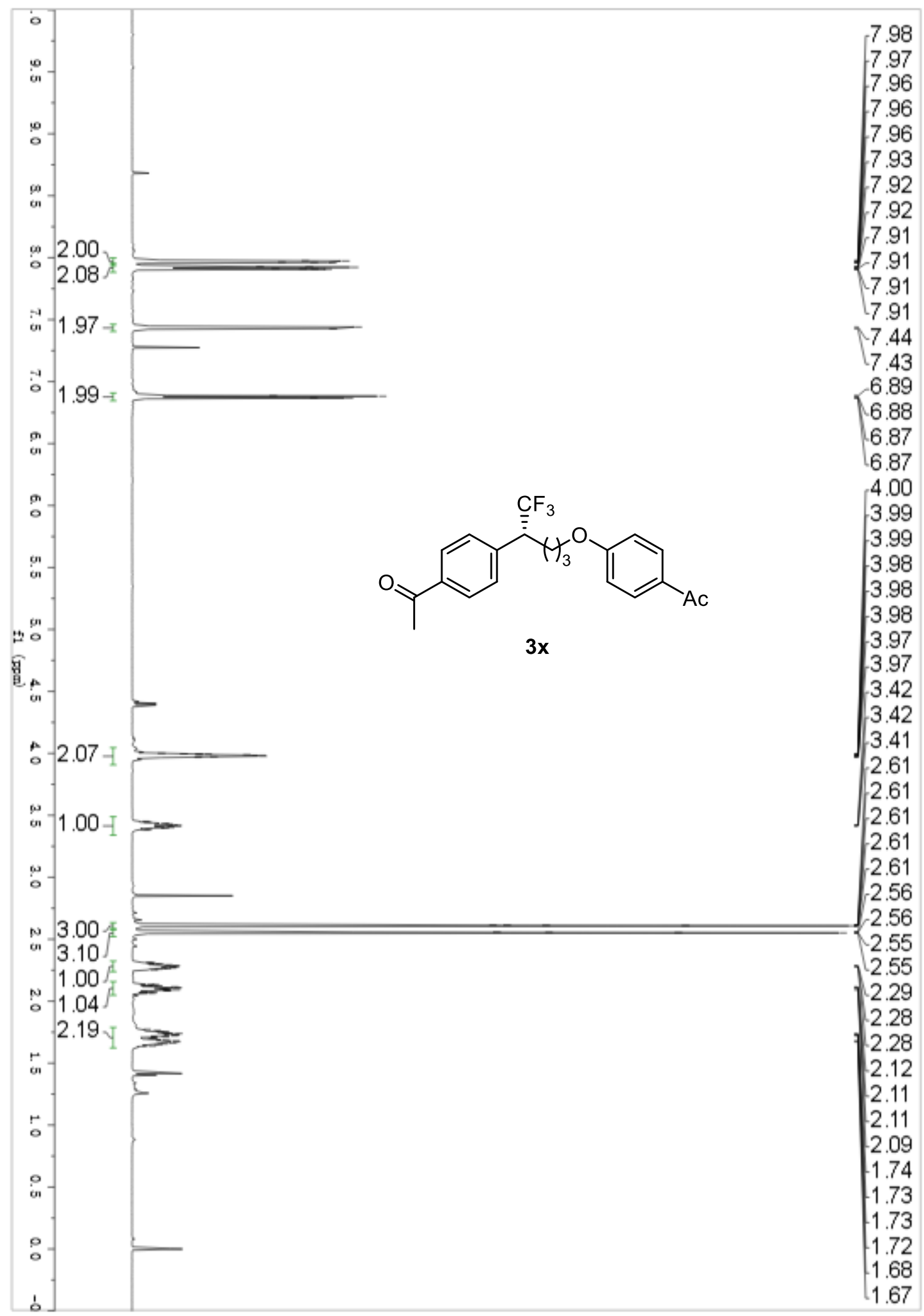


Compound 3y ${ }^{1} \mathrm{H}$ NMR (600 MHz, $\left.\mathrm{CDCl}_{3}\right)$

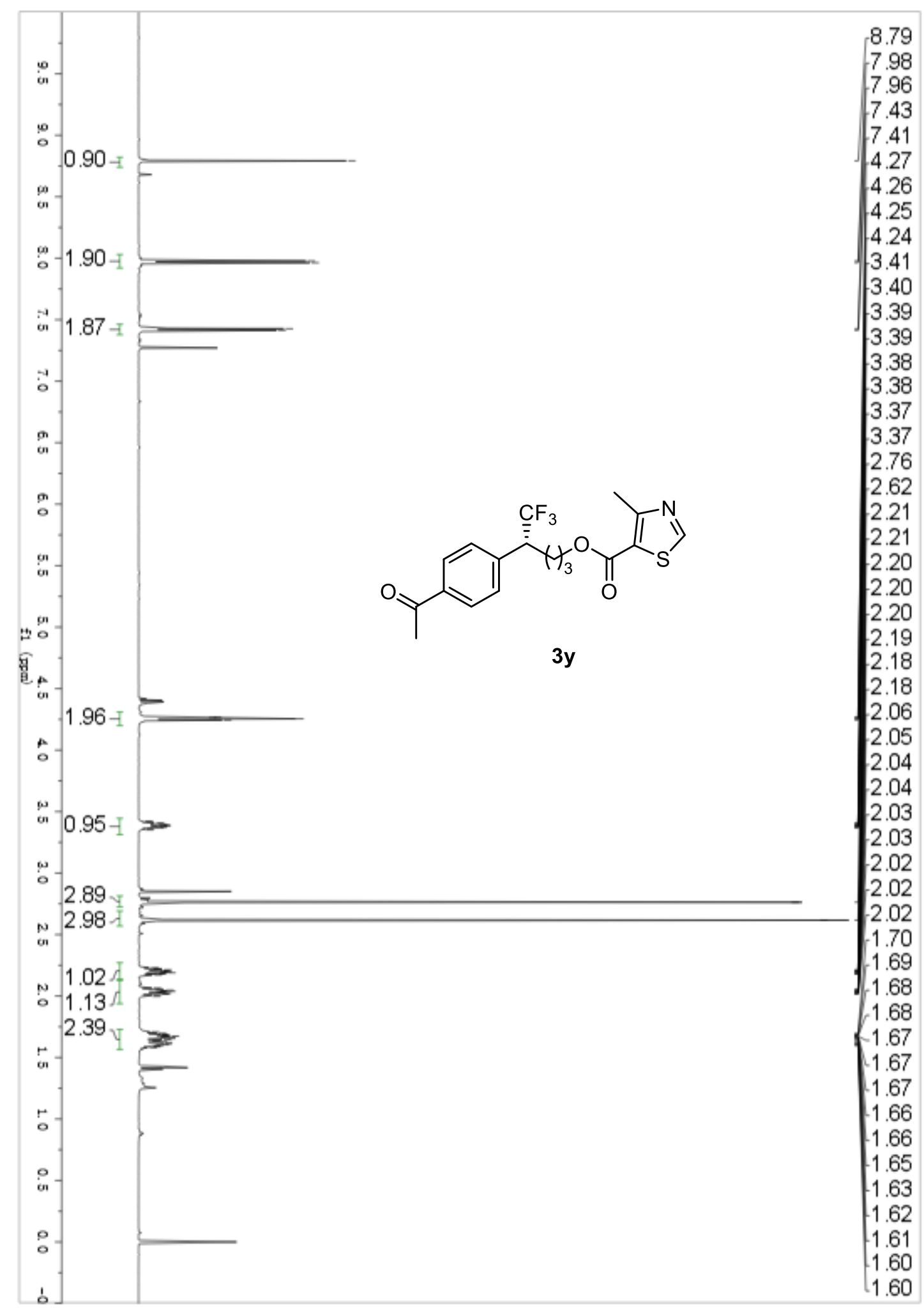


Compound $\mathbf{3 z}{ }^{1} \mathrm{H}$ NMR (600 MHz, $\left.\mathrm{CDCl}_{3}\right)$

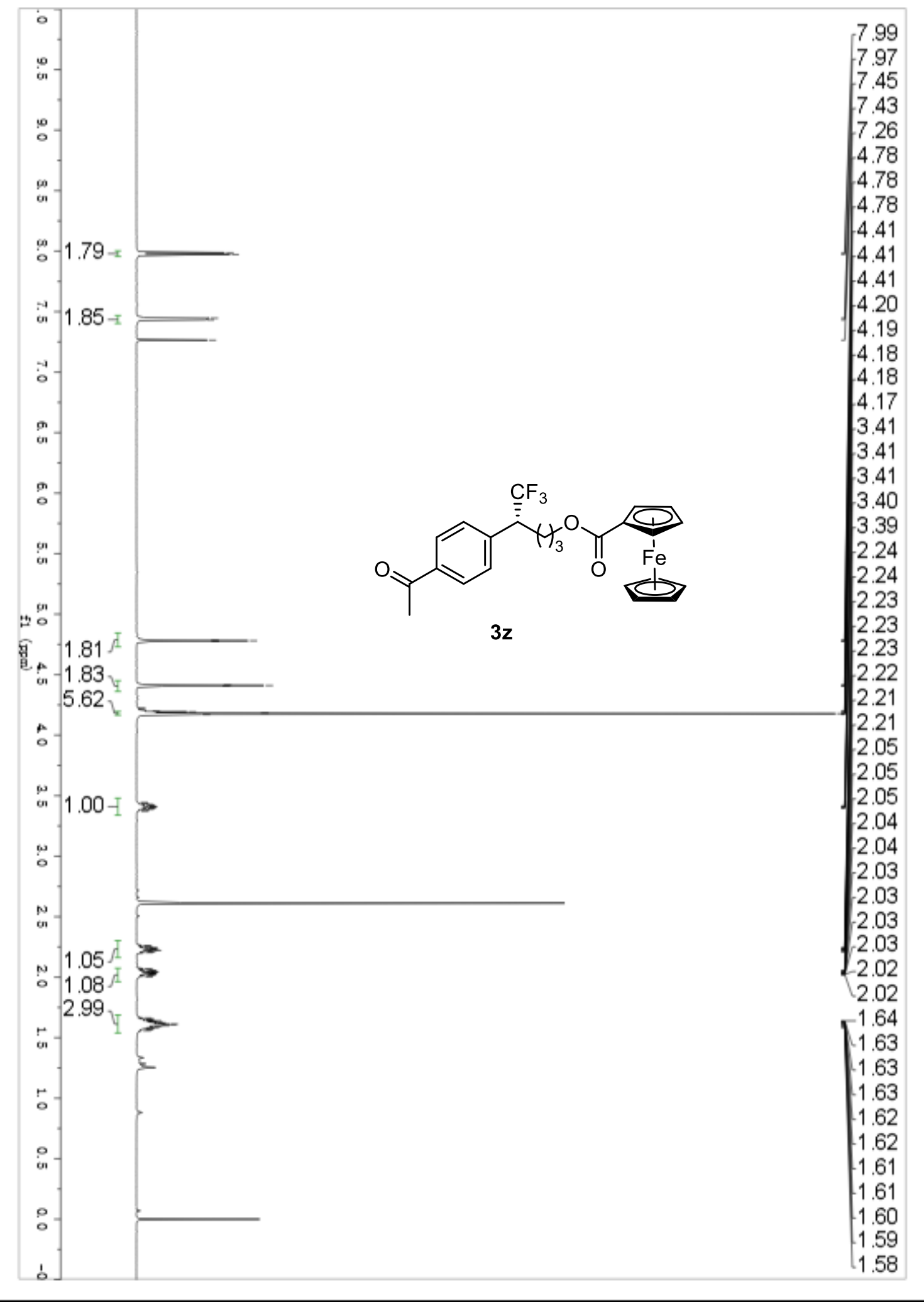


Compound 3aa ${ }^{1} \mathrm{H}$ NMR $\left(600 \mathrm{MHz}, \mathrm{CDCl}_{3}\right)$

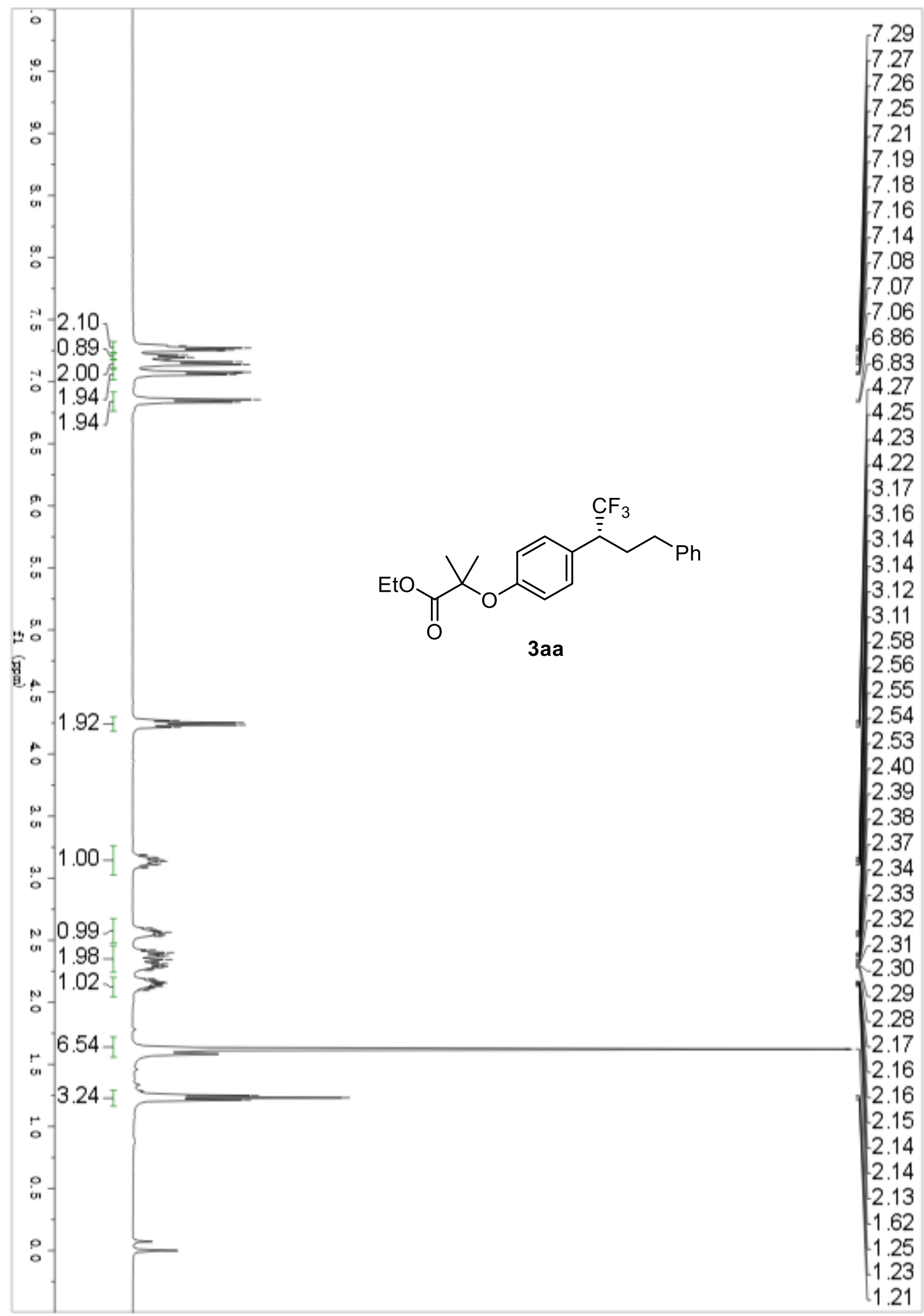


Compound 3bb ${ }^{1} \mathrm{H}$ NMR (600 MHz, $\left.\mathrm{CDCl}_{3}\right)$

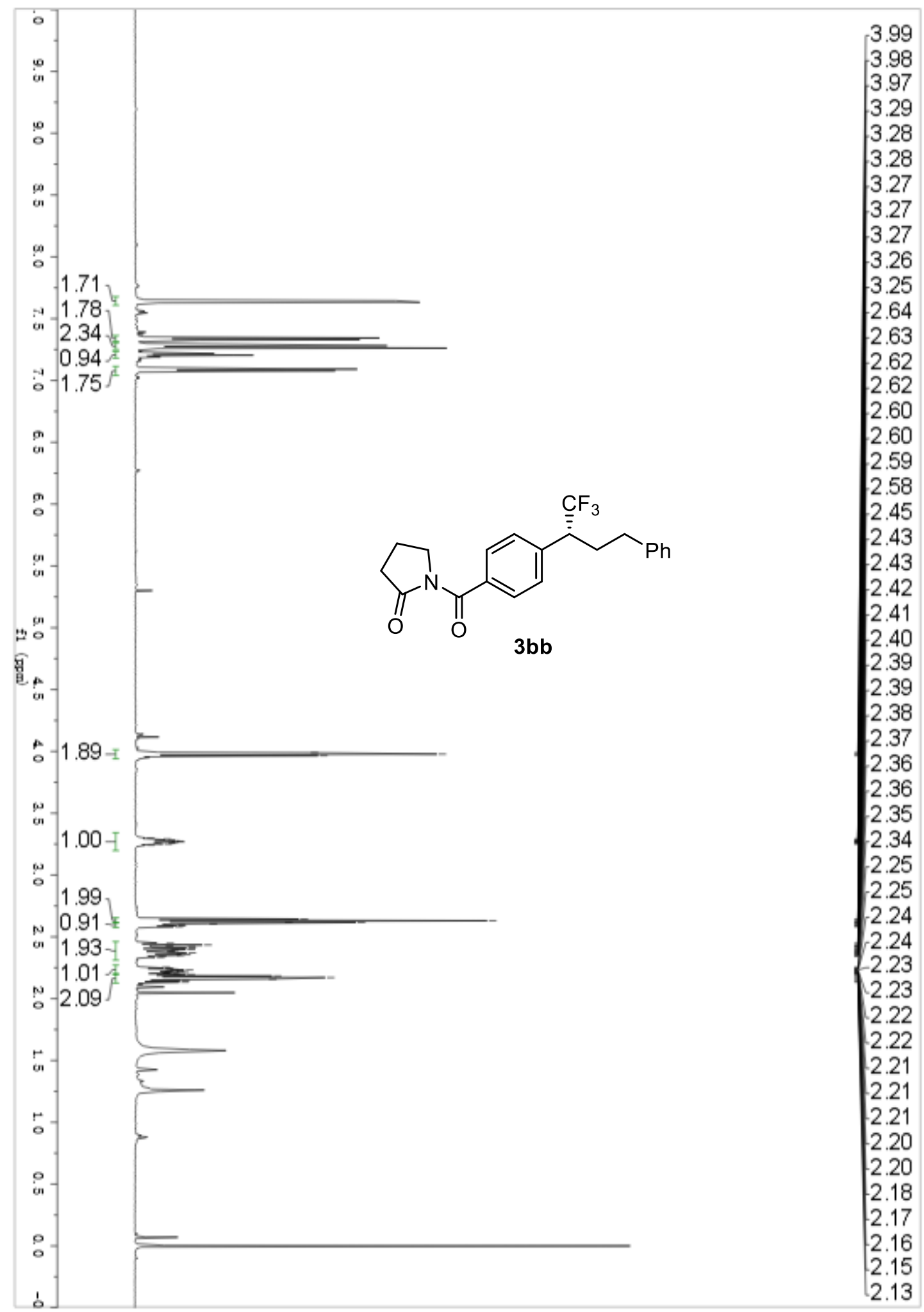


Compound 3ce ${ }^{1} \mathrm{H}$ NMR $\left(600 \mathrm{MHz}, \mathrm{CDCl}_{3}\right)$

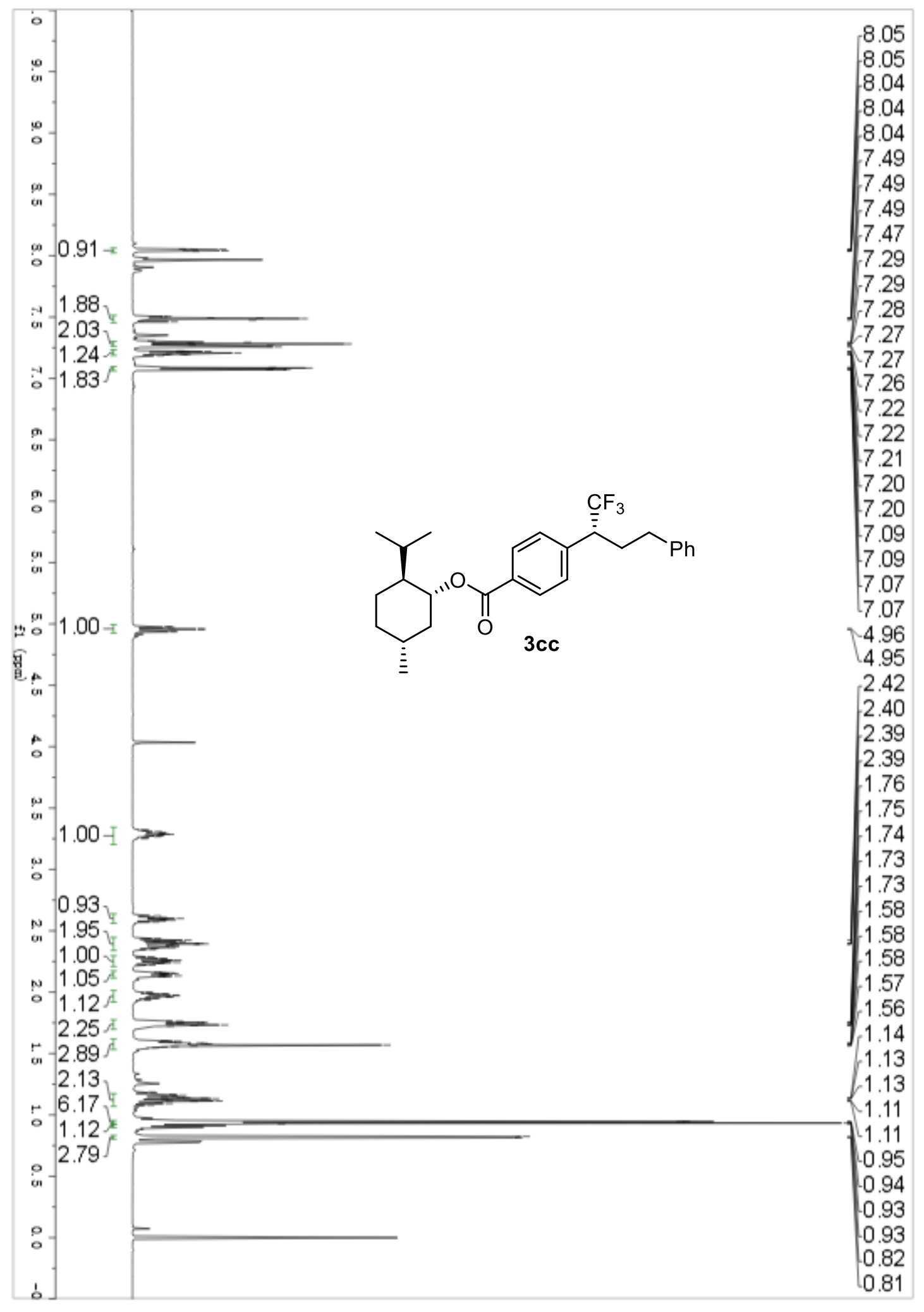


Compound 3cc ${ }^{13} \mathrm{C}$ NMR (151 MHz, $\mathrm{CDCl}_{3}$ )

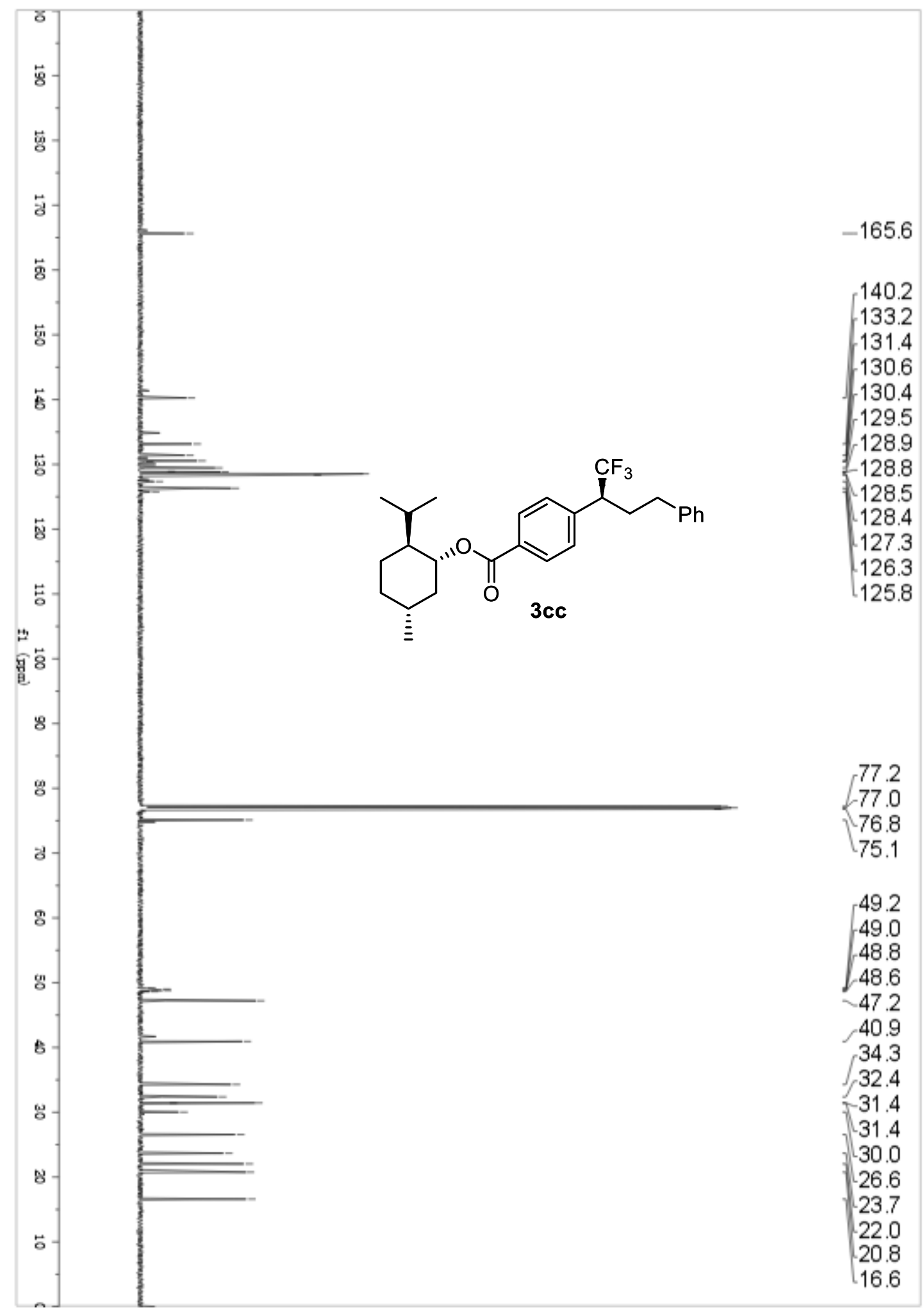


Compound 3cc ${ }^{19} \mathrm{~F}$ NMR (565 MHz, $\mathrm{CDCl}_{3}$ )

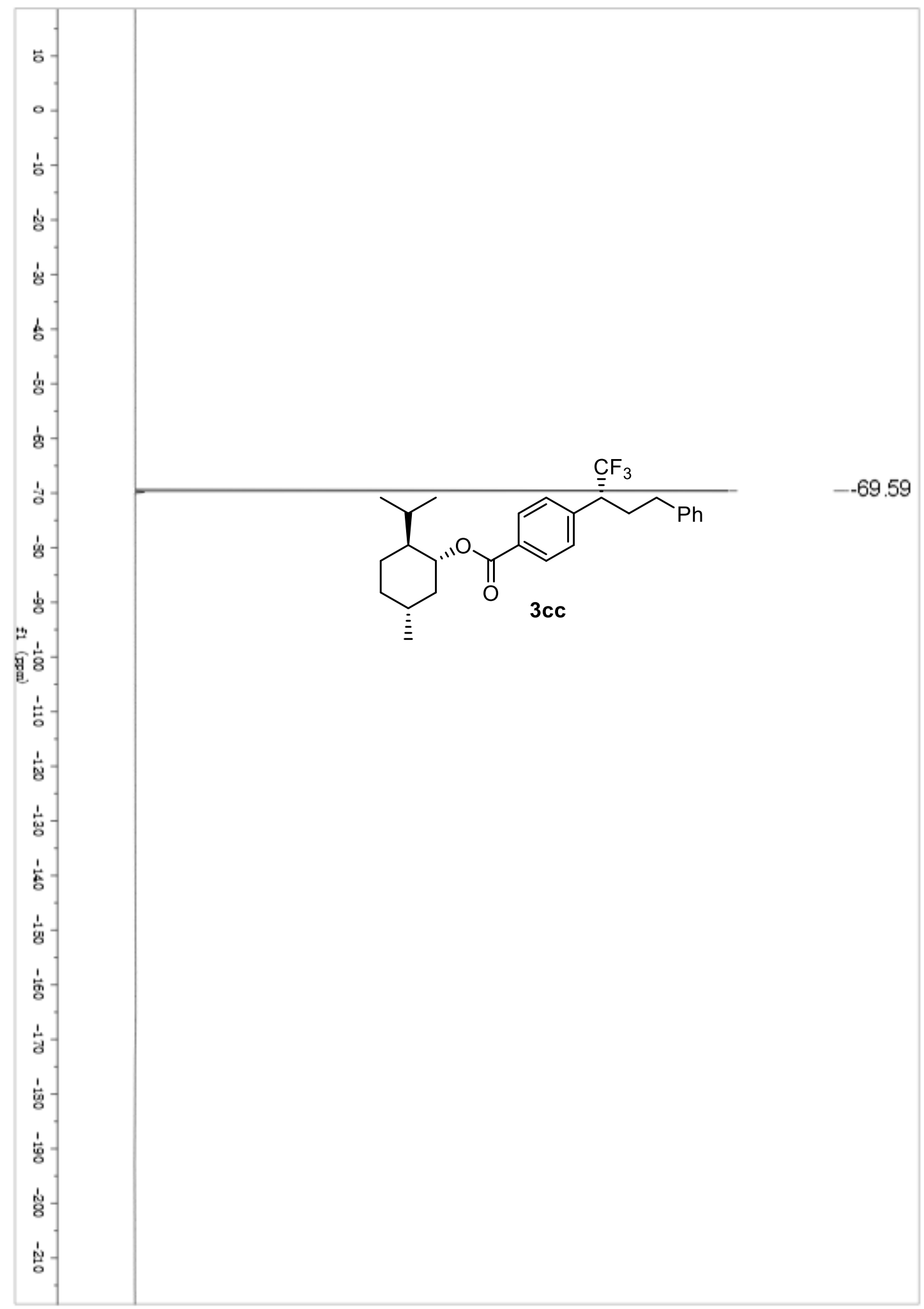


Compound 3dd ${ }^{1} \mathrm{H}$ NMR (600 MHz, $\left.\mathrm{CDCl}_{3}\right)$

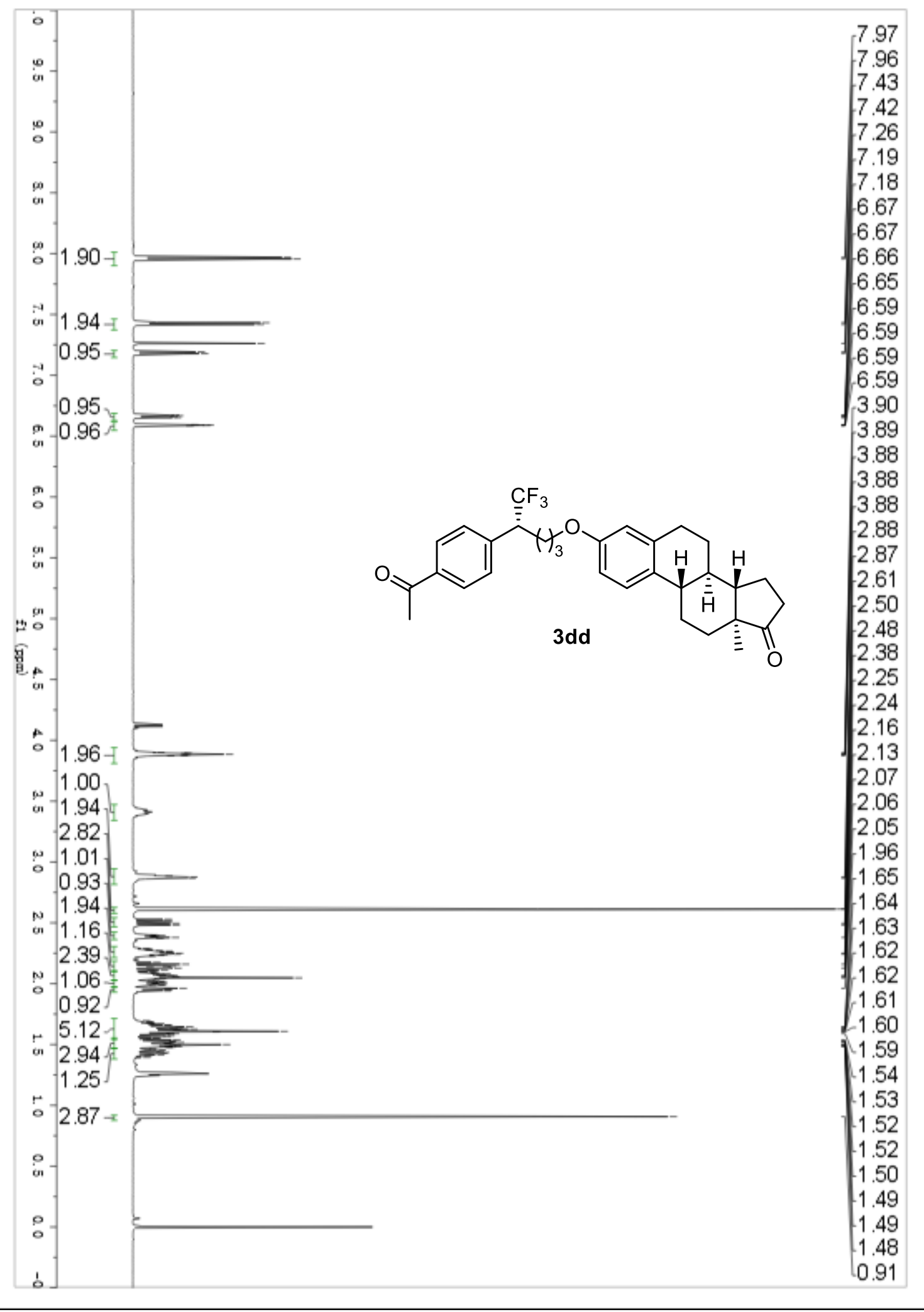


Compound 3dd ${ }^{13} \mathrm{C}$ NMR (151 MHz, $\left.\mathrm{CDCl}_{3}\right)$

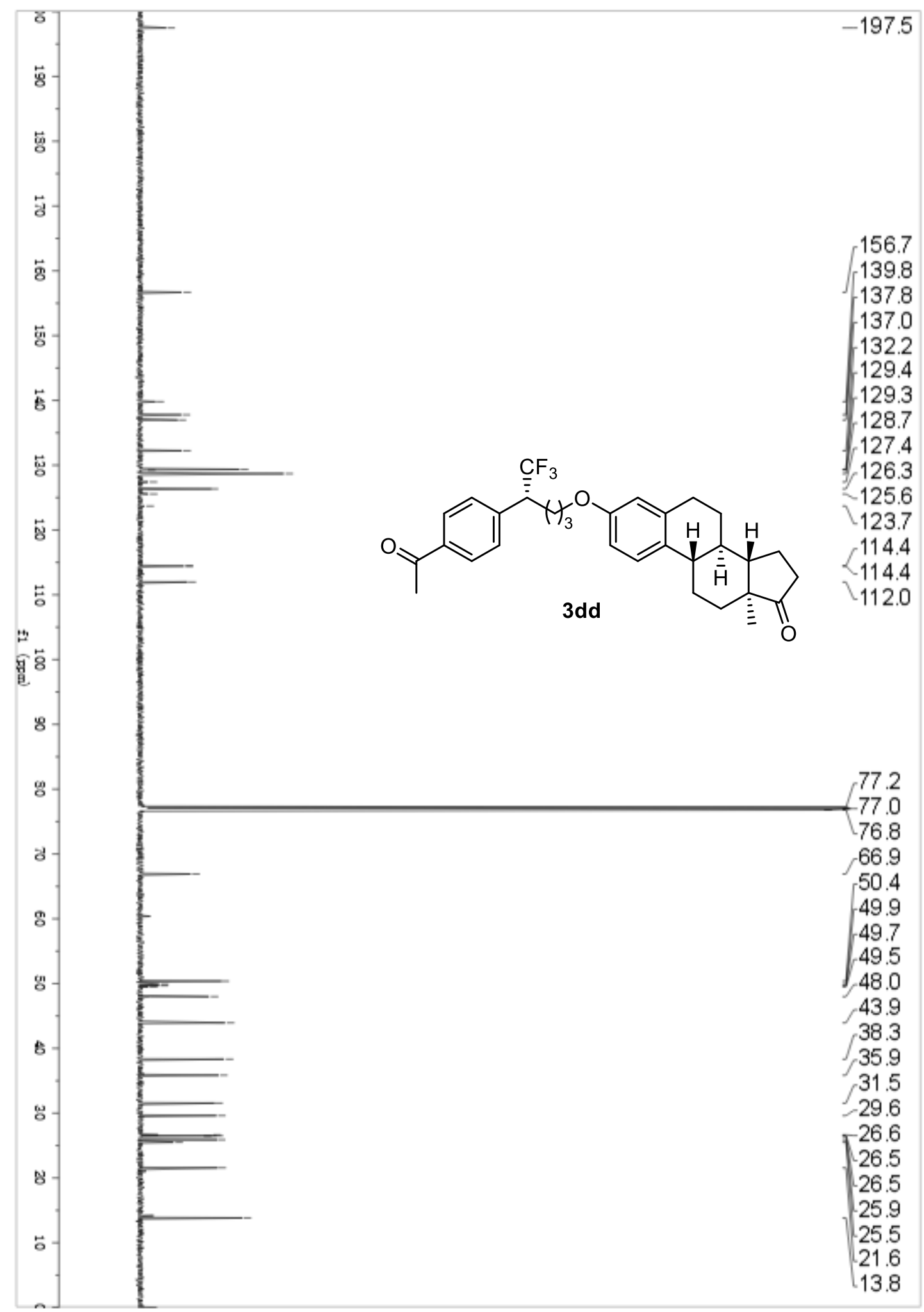


Compound 3dd ${ }^{19} \mathrm{~F}$ NMR (565 MHz, $\mathrm{CDCl}_{3}$ )

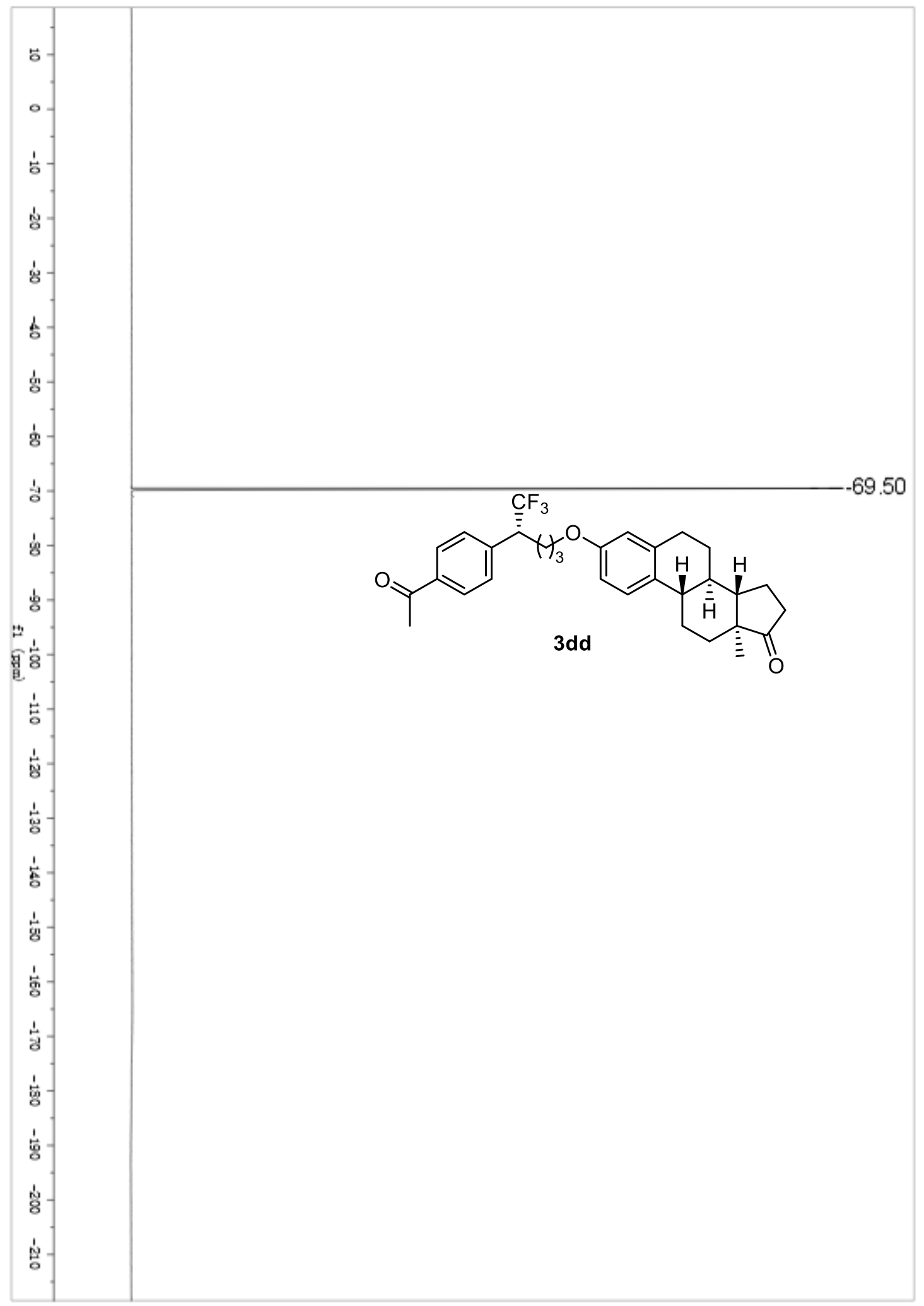


Compound 3ee ${ }^{1} \mathrm{H}$ NMR (600 MHz, $\left.\mathrm{CDCl}_{3}\right)$

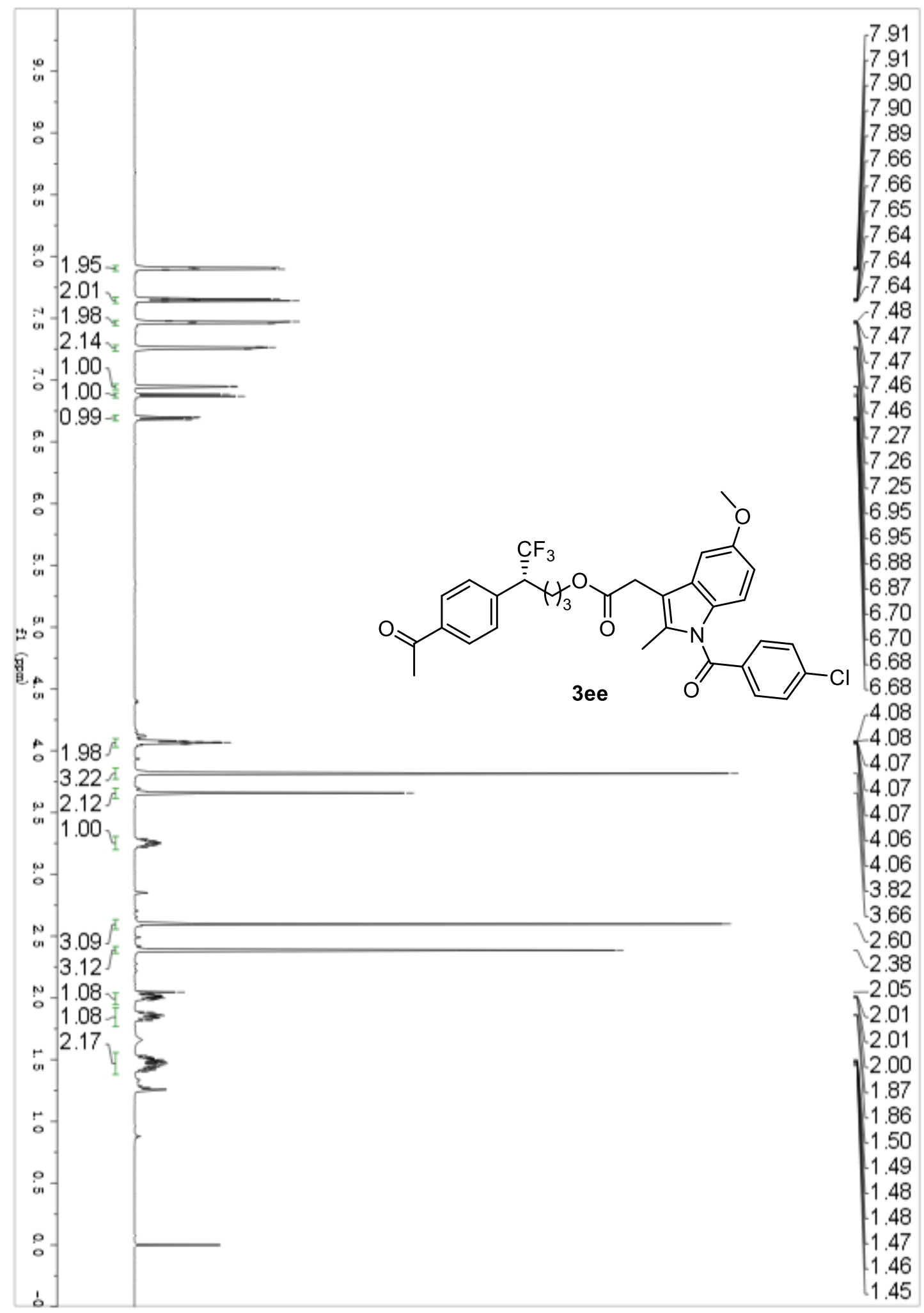


Compound 3ee ${ }^{13} \mathrm{C}$ NMR (151 MHz, $\left.\mathrm{CDCl}_{3}\right)$

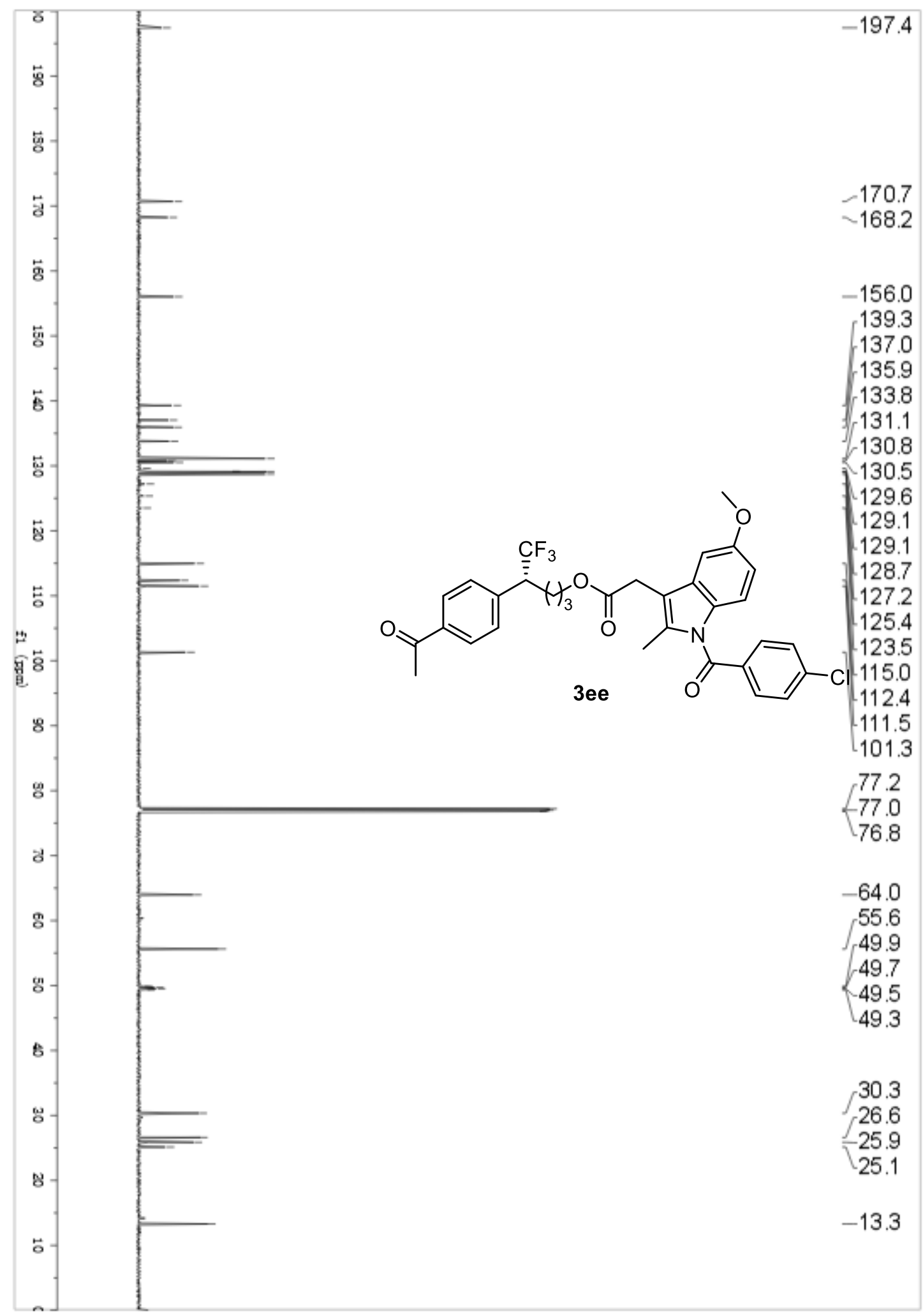


Compound 3ee ${ }^{19} \mathrm{~F}$ NMR (565 MHz, $\mathrm{CDCl}_{3}$ )

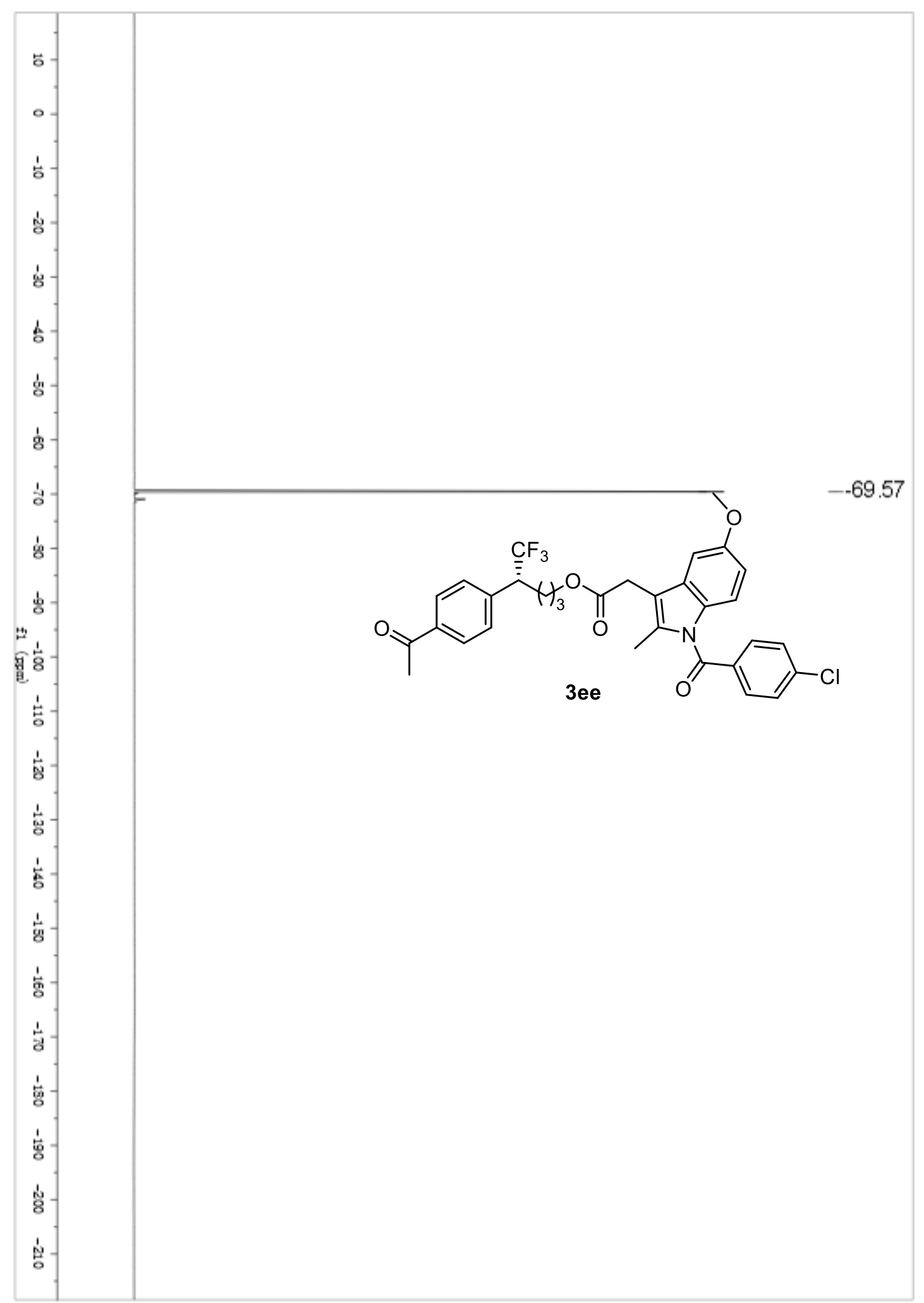


Compound 3ff ${ }^{1} \mathrm{H}$ NMR (600 MHz, $\mathrm{CDCl}_{3}$ )

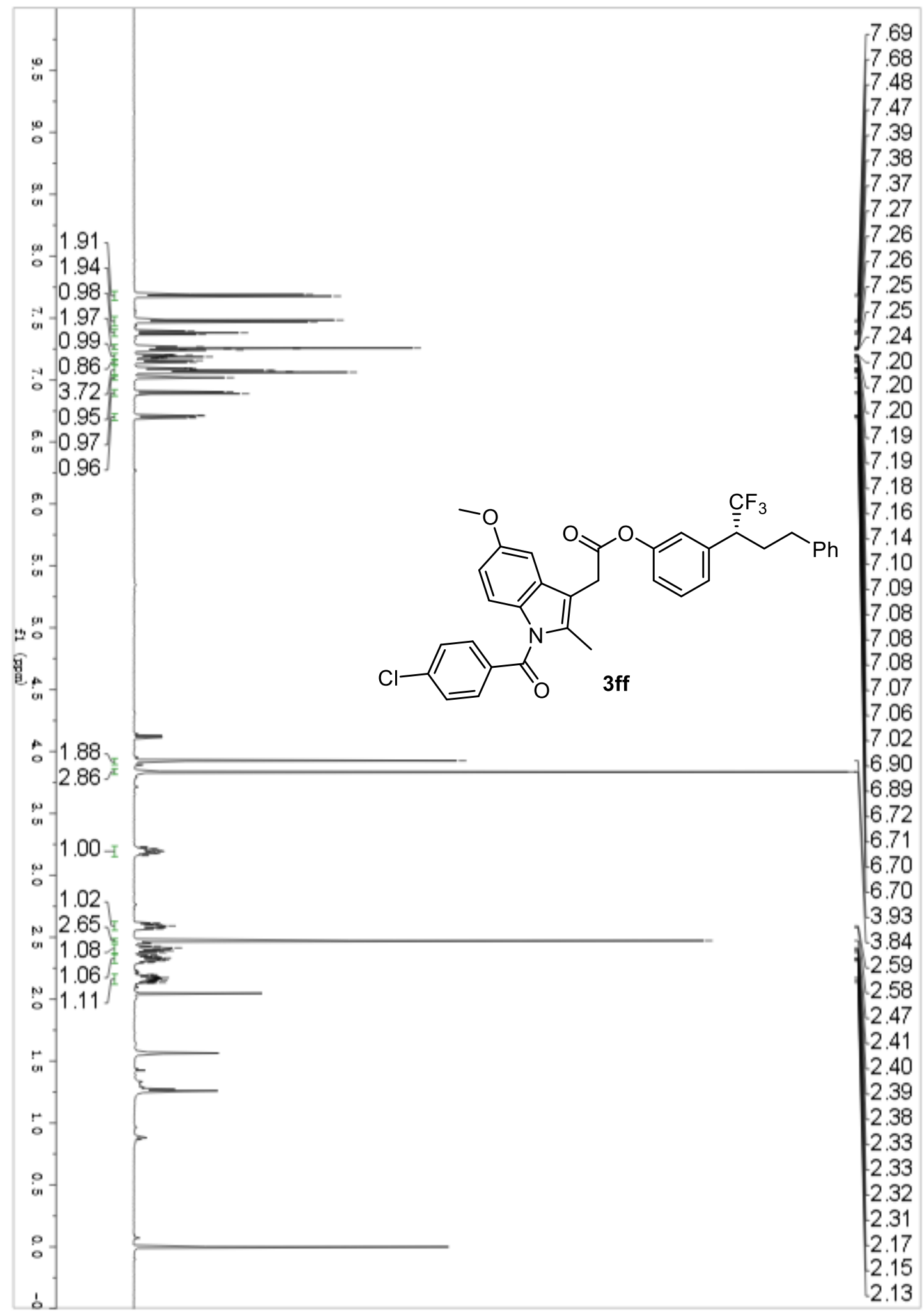


Compound 3ff ${ }^{13} \mathrm{C}$ NMR (151 MHz, $\mathrm{CDCl}_{3}$ )

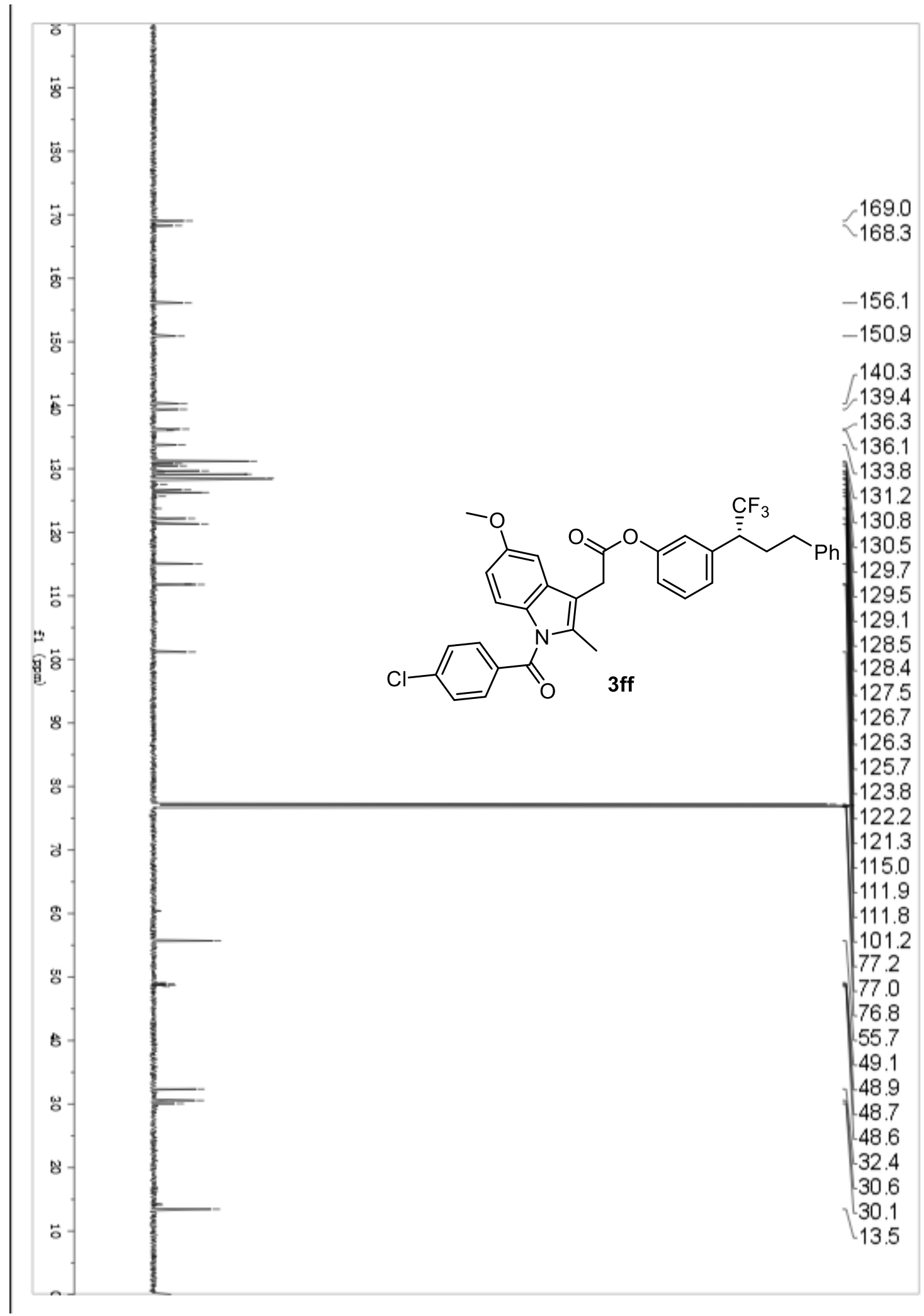


Compound 3ff ${ }^{19} \mathrm{~F}$ NMR (565 MHz, $\mathrm{CDCl}_{3}$ )

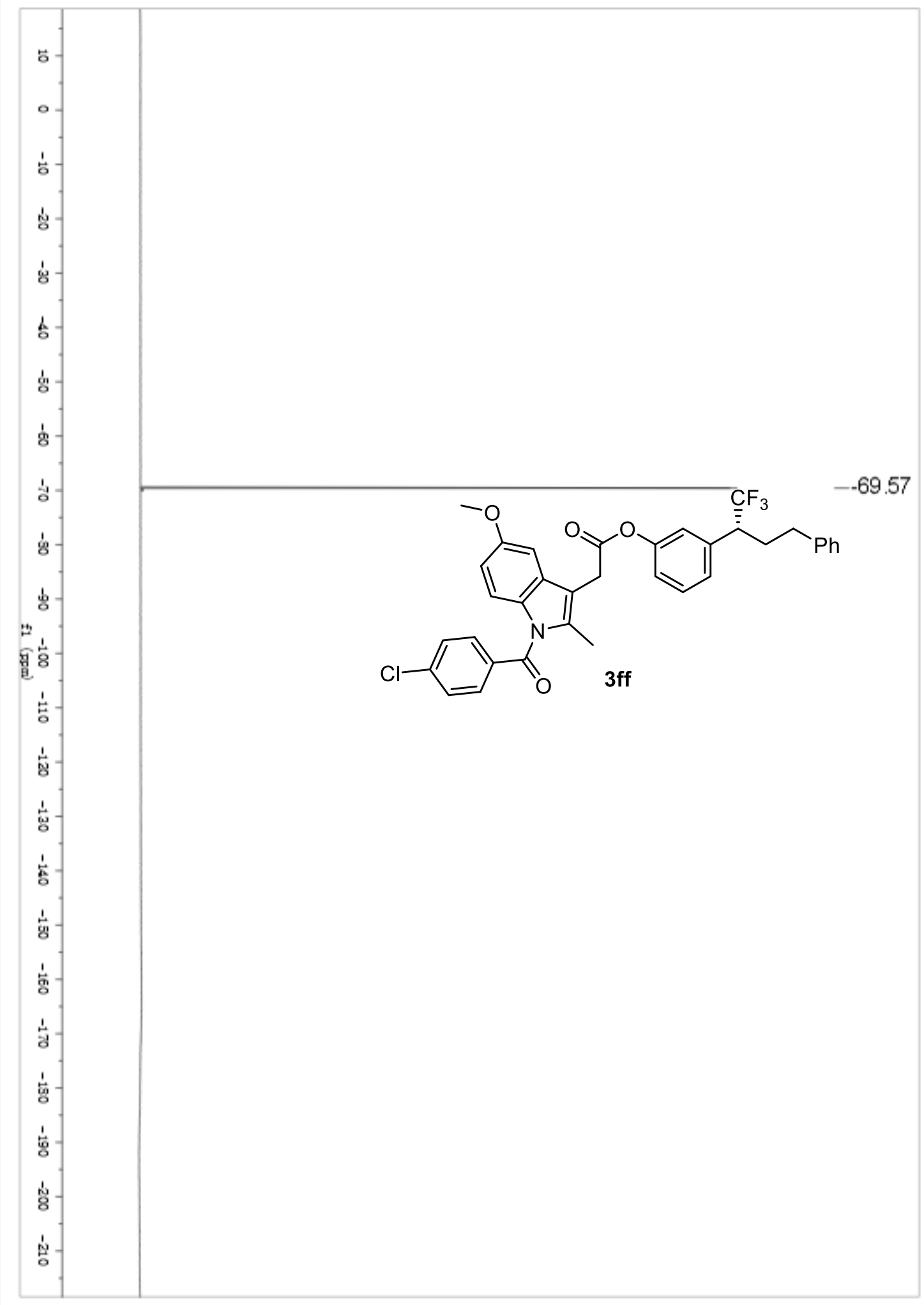


Compound 3gg ${ }^{1} \mathrm{H}$ NMR $\left(600 \mathrm{MHz}, \mathrm{CDCl}_{3}\right)$

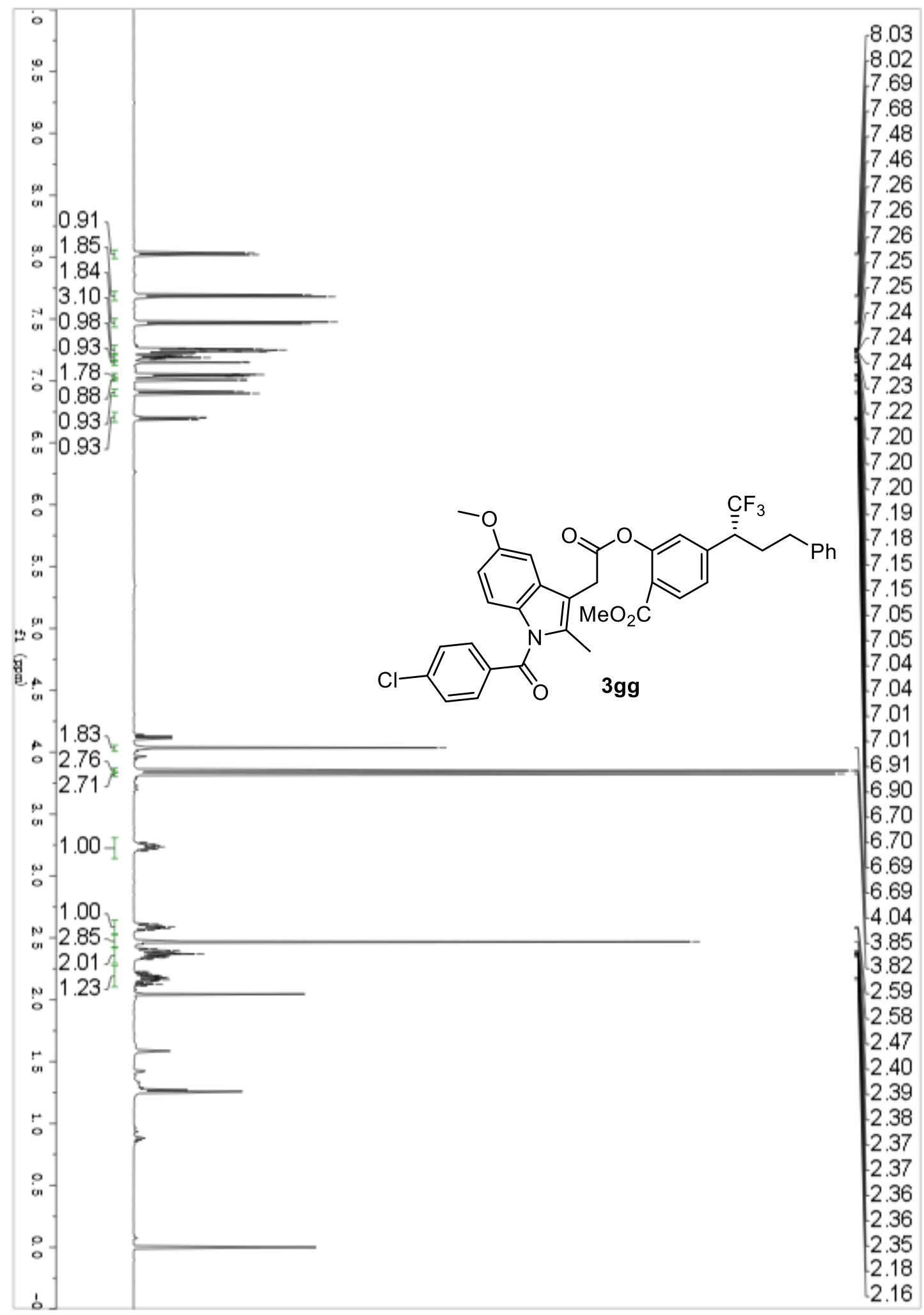


Compound 3gg ${ }^{13} \mathrm{C}$ NMR (151 MHz, $\mathrm{CDCl}_{3}$ )

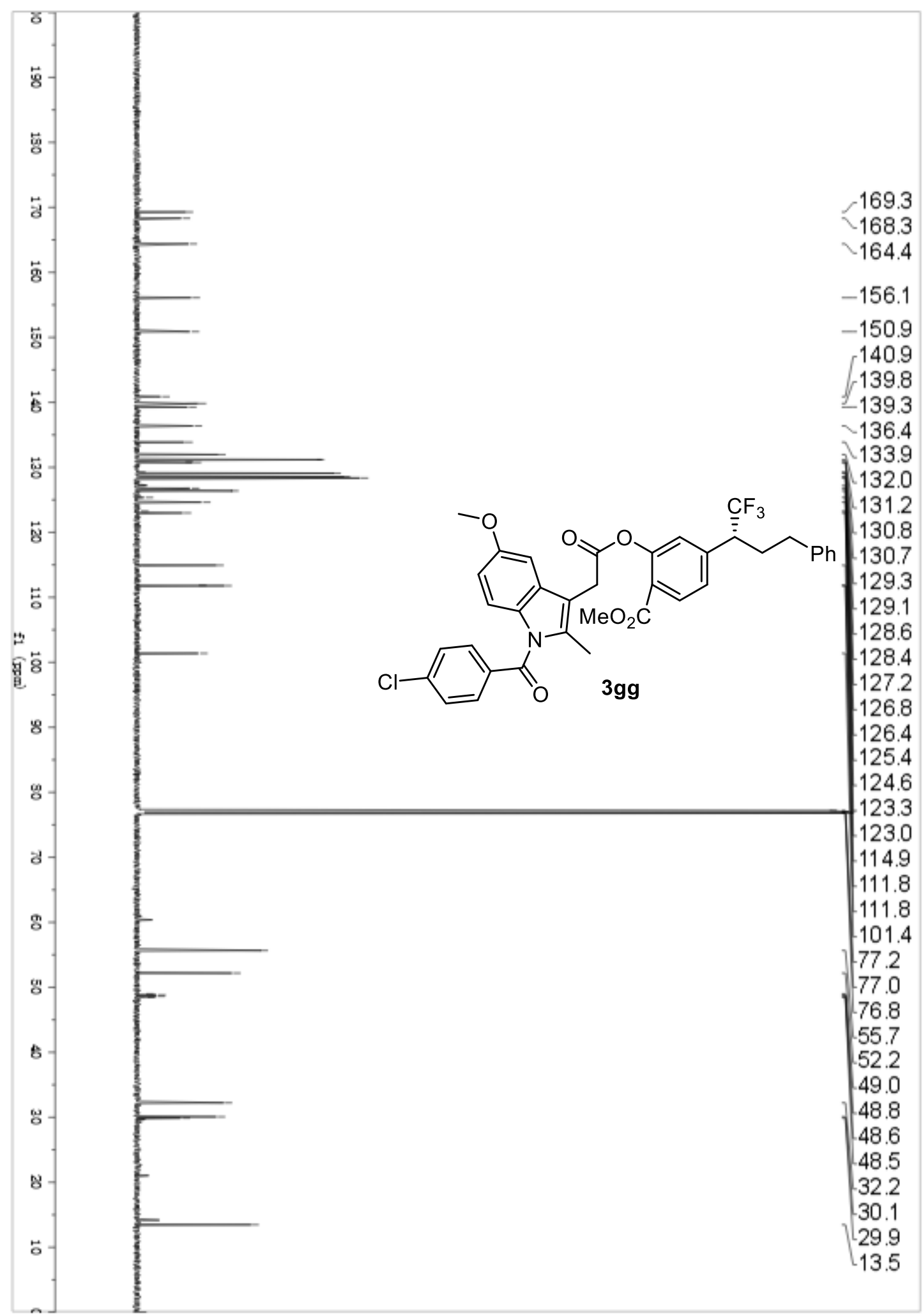


Compound 3gg ${ }^{19} \mathrm{~F}$ NMR (565 MHz, $\left.\mathrm{CDCl}_{3}\right)$

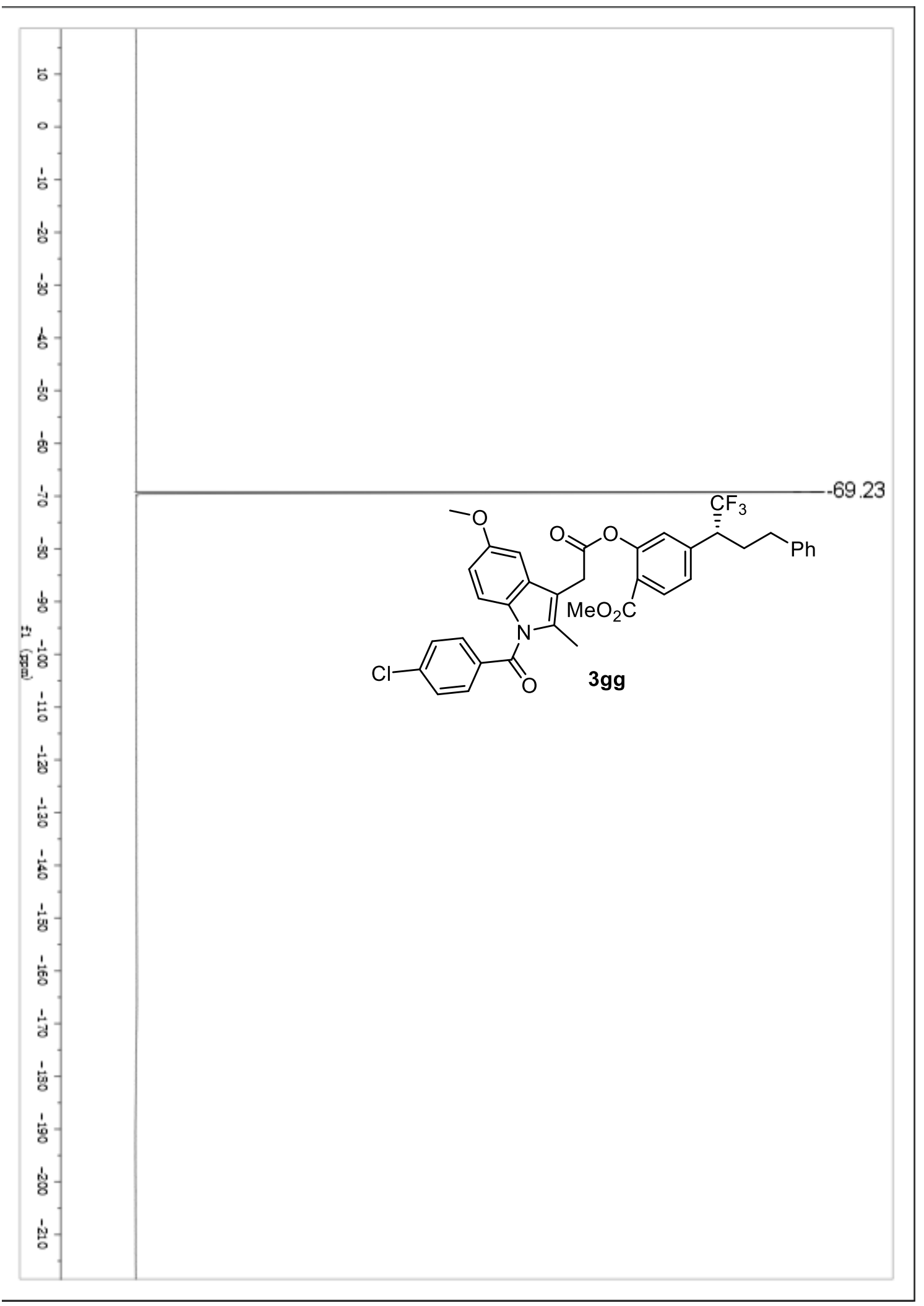


Compound $4{ }^{1} \mathrm{H}$ NMR (600 MHz, $\left.\mathrm{CDCl}_{3}\right)$

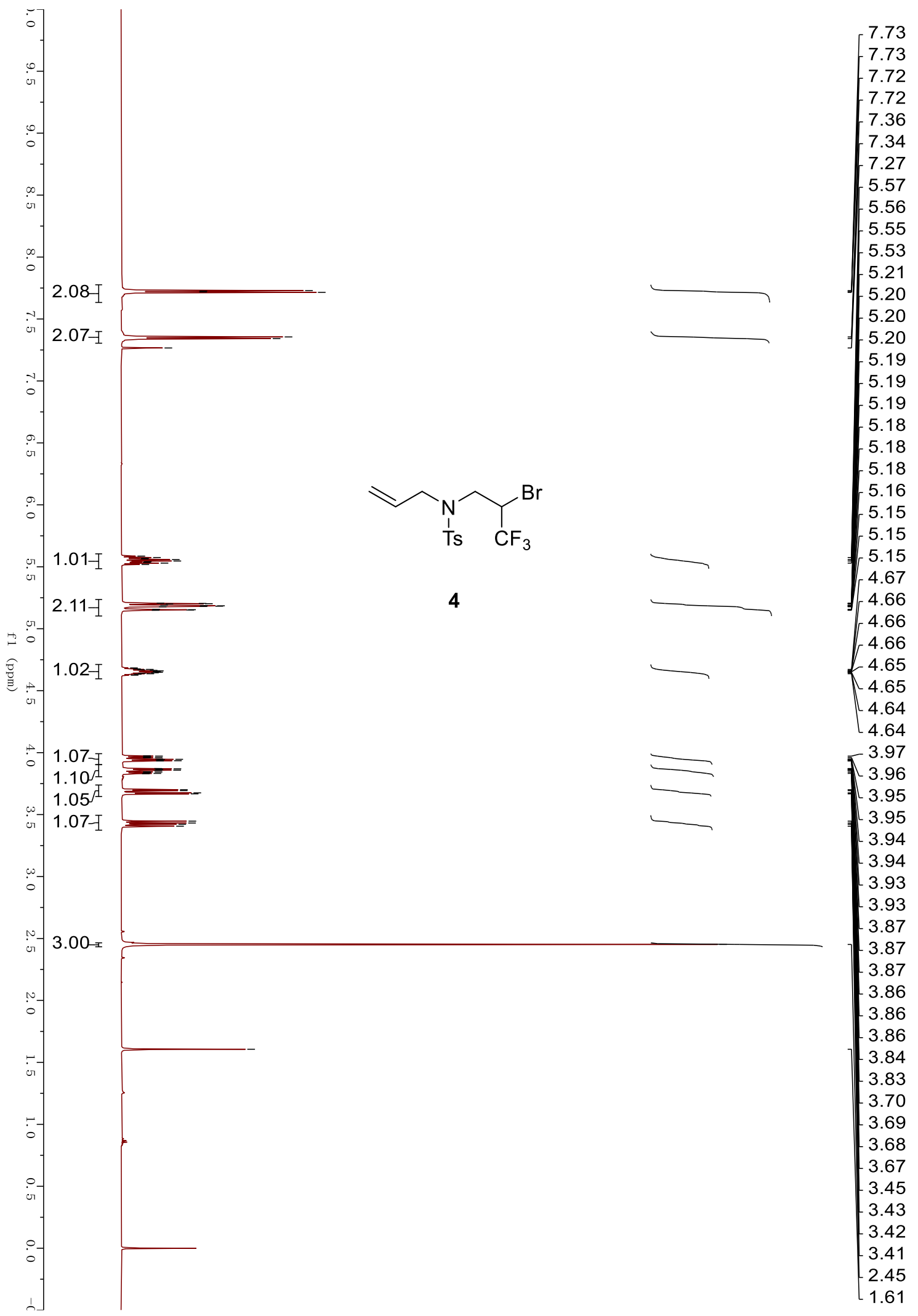


Compound $4{ }^{13} \mathrm{C}$ NMR $\left(151 \mathrm{MHz}, \mathrm{CDCl}_{3}\right)$

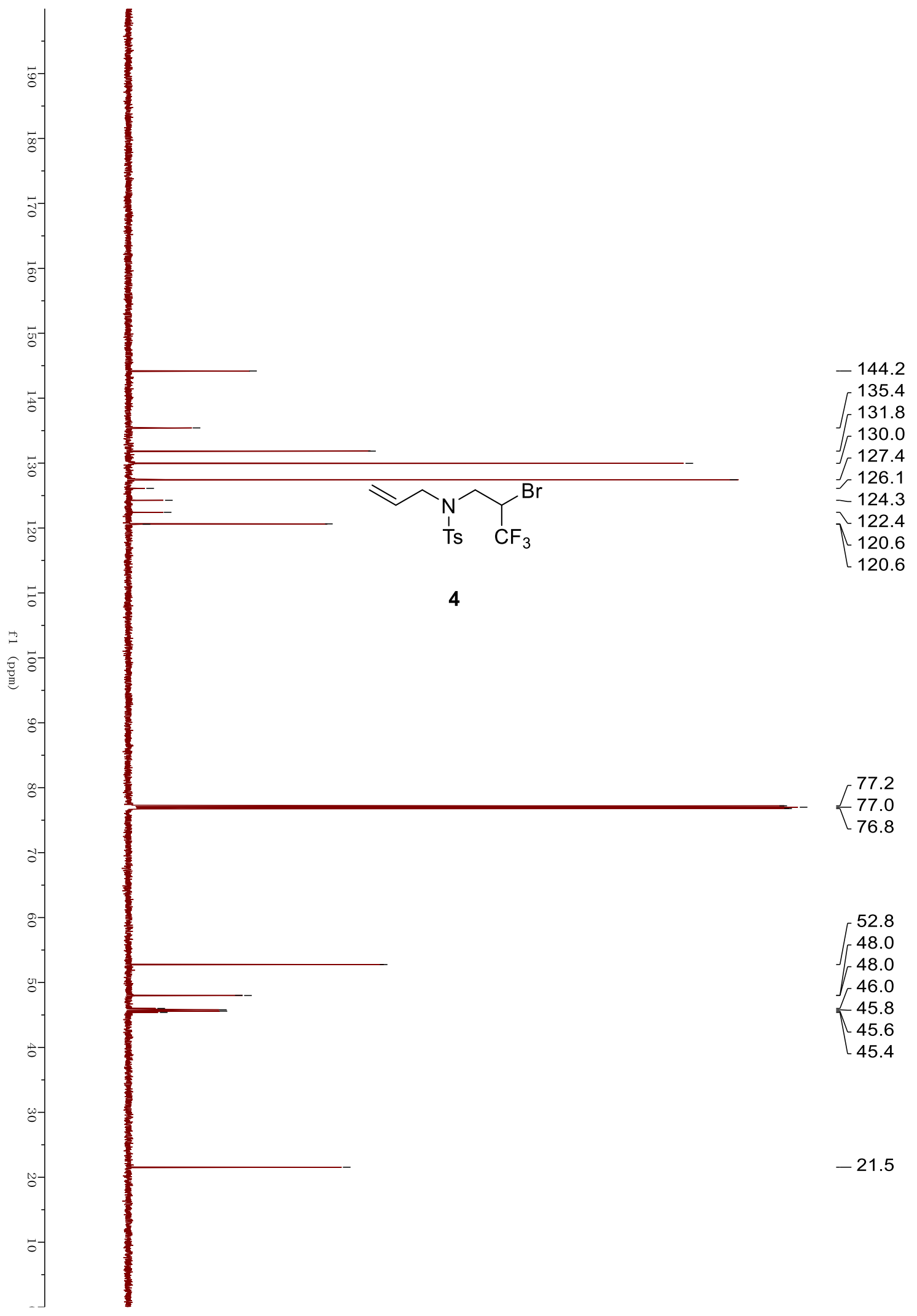


Compound $4{ }^{19} \mathrm{~F}$ NMR $\left(565 \mathrm{MHz}, \mathrm{CDCl}_{3}\right.$ )

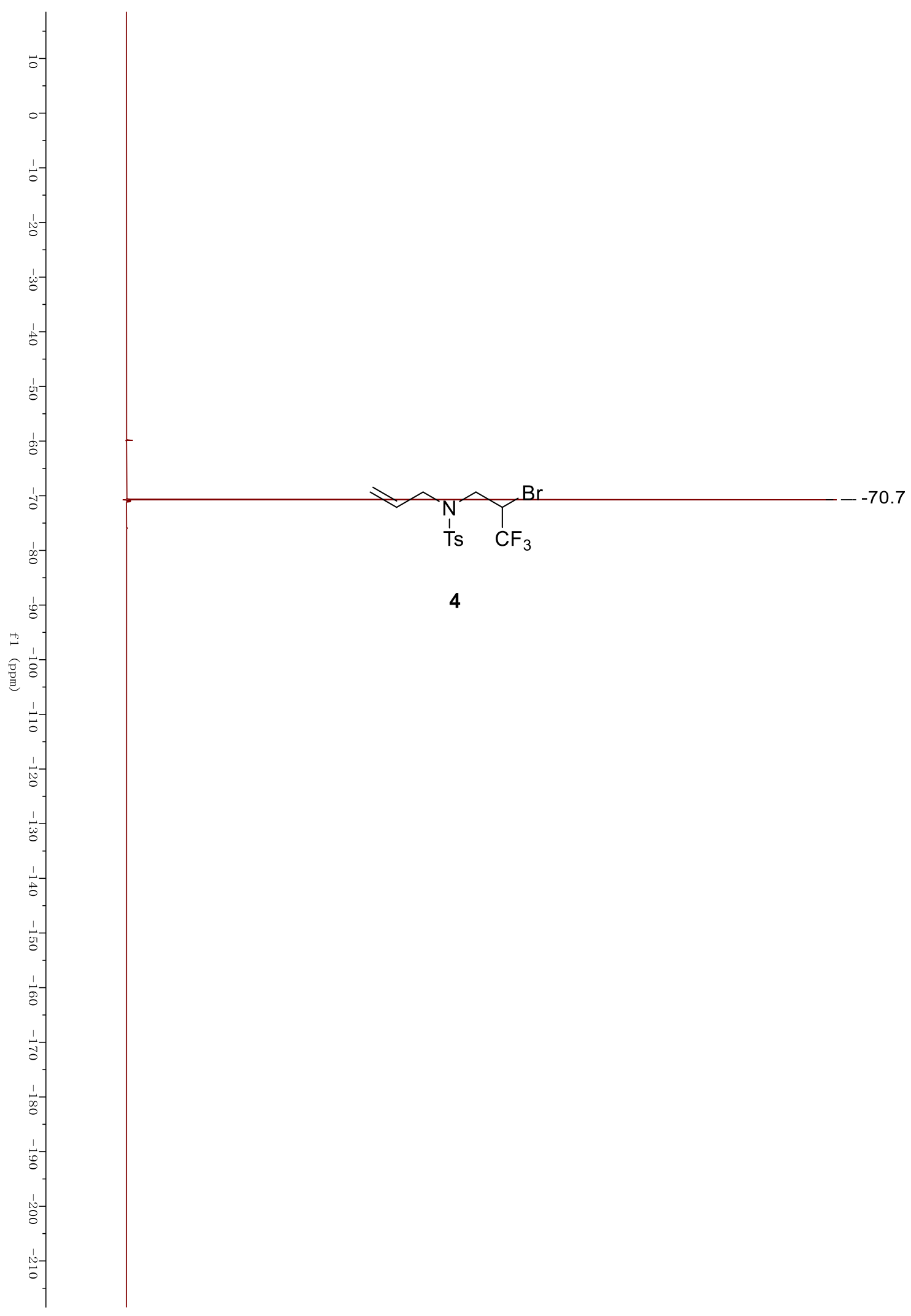


Compound 5a ${ }^{1} \mathrm{H}$ NMR $\left(600 \mathrm{MHz}, \mathrm{CDCl}_{3}\right)$

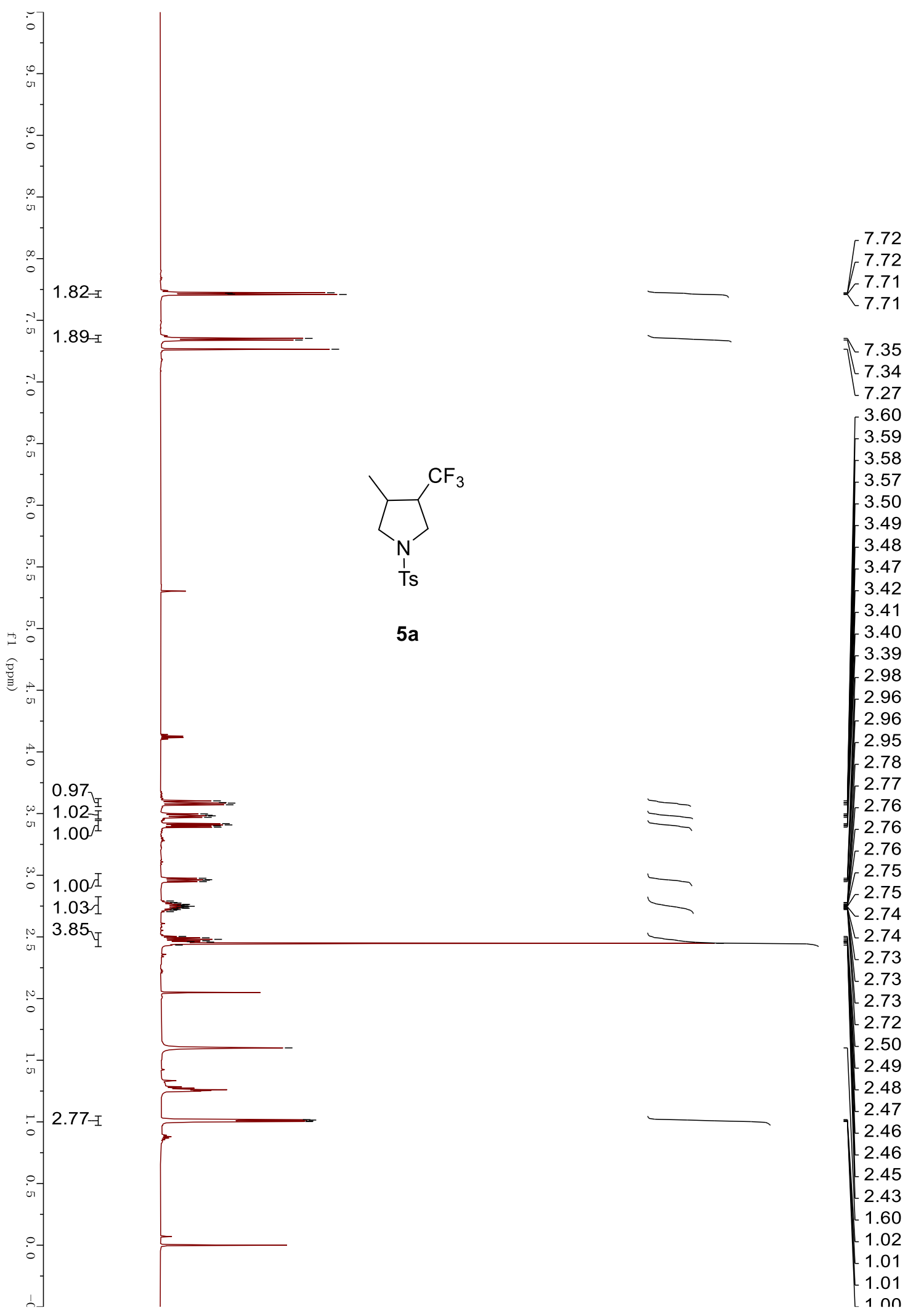


Compound 5a ${ }^{13} \mathrm{C}$ NMR (151 MHz, $\left.\mathrm{CDCl}_{3}\right)$

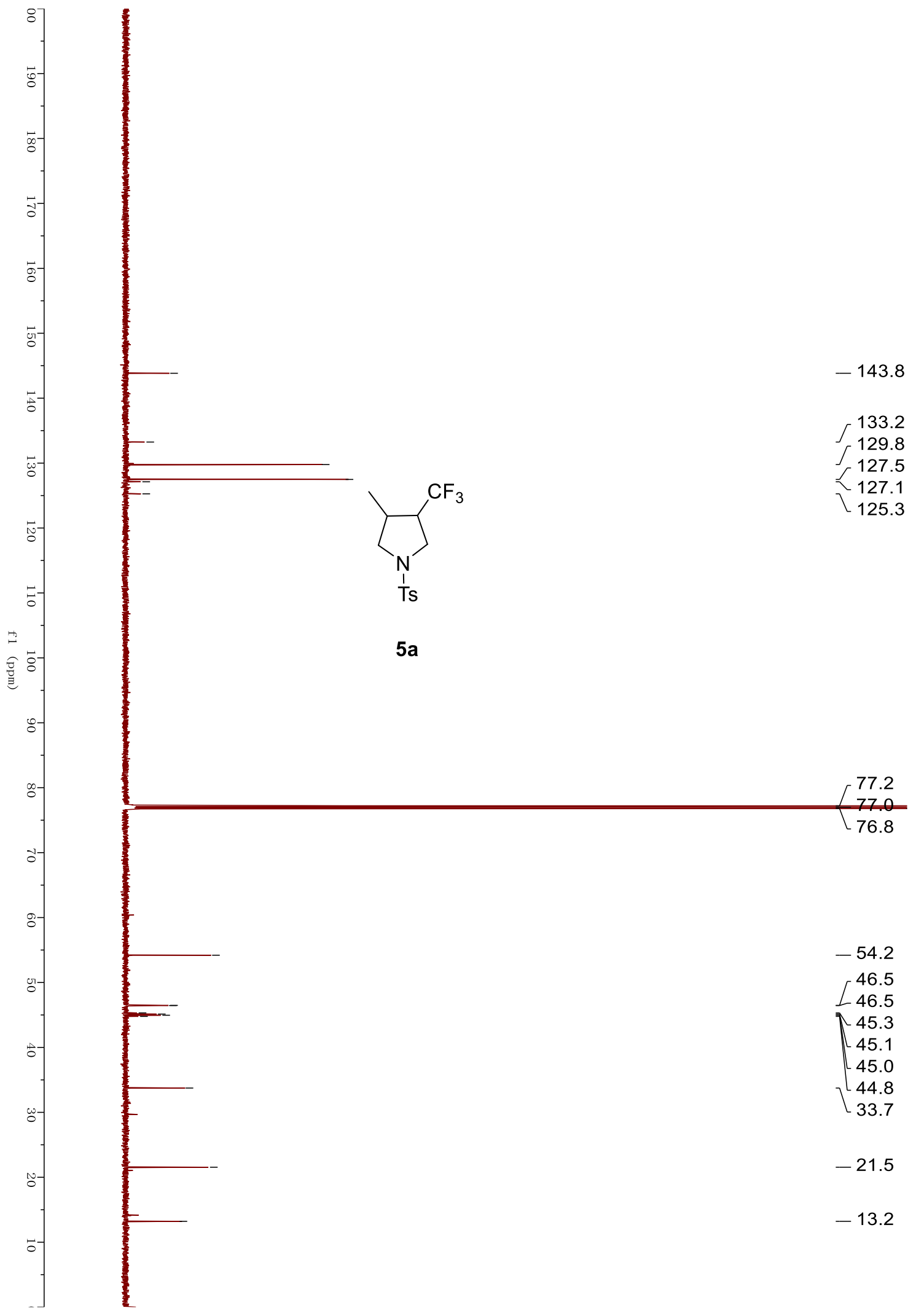


Compound 5a ${ }^{19} \mathrm{~F}$ NMR (565 MHz, $\mathrm{CDCl}_{3}$ )

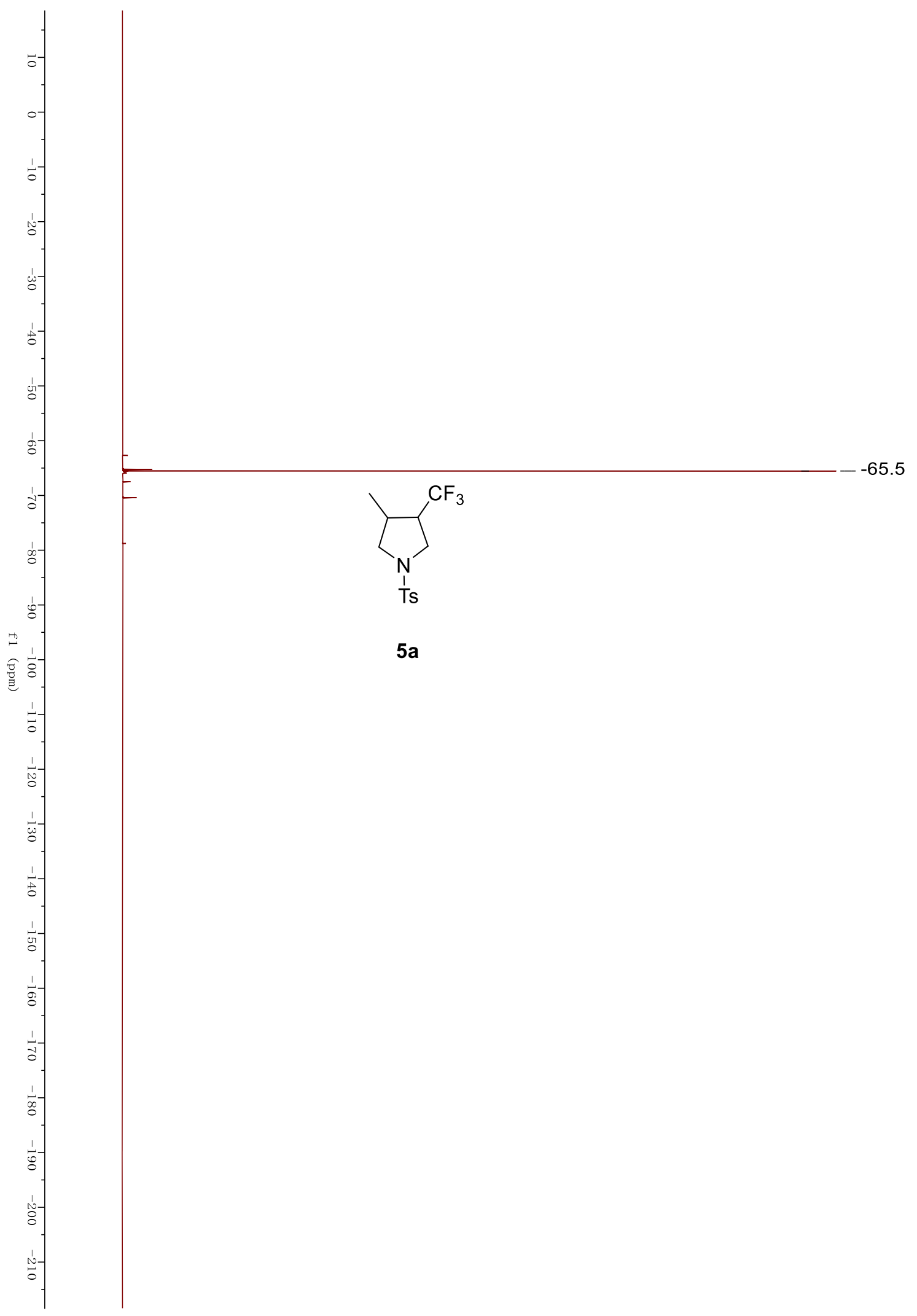


Compound 5b ${ }^{1} \mathrm{H}$ NMR $\left(600 \mathrm{MHz}, \mathrm{CDCl}_{3}\right)$

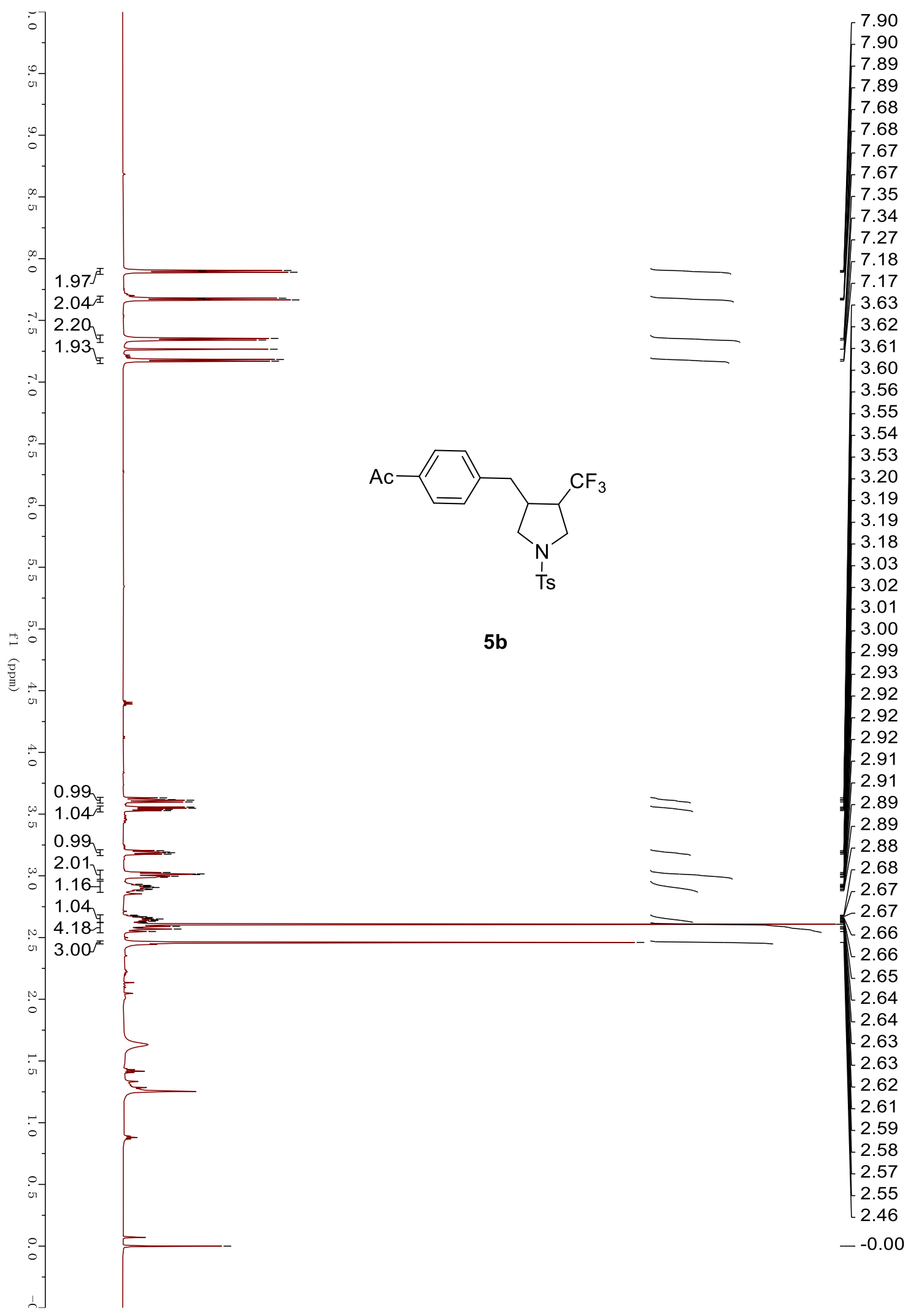


Compound 5b ${ }^{13} \mathrm{C}$ NMR (151 MHz, $\left.\mathrm{CDCl}_{3}\right)$

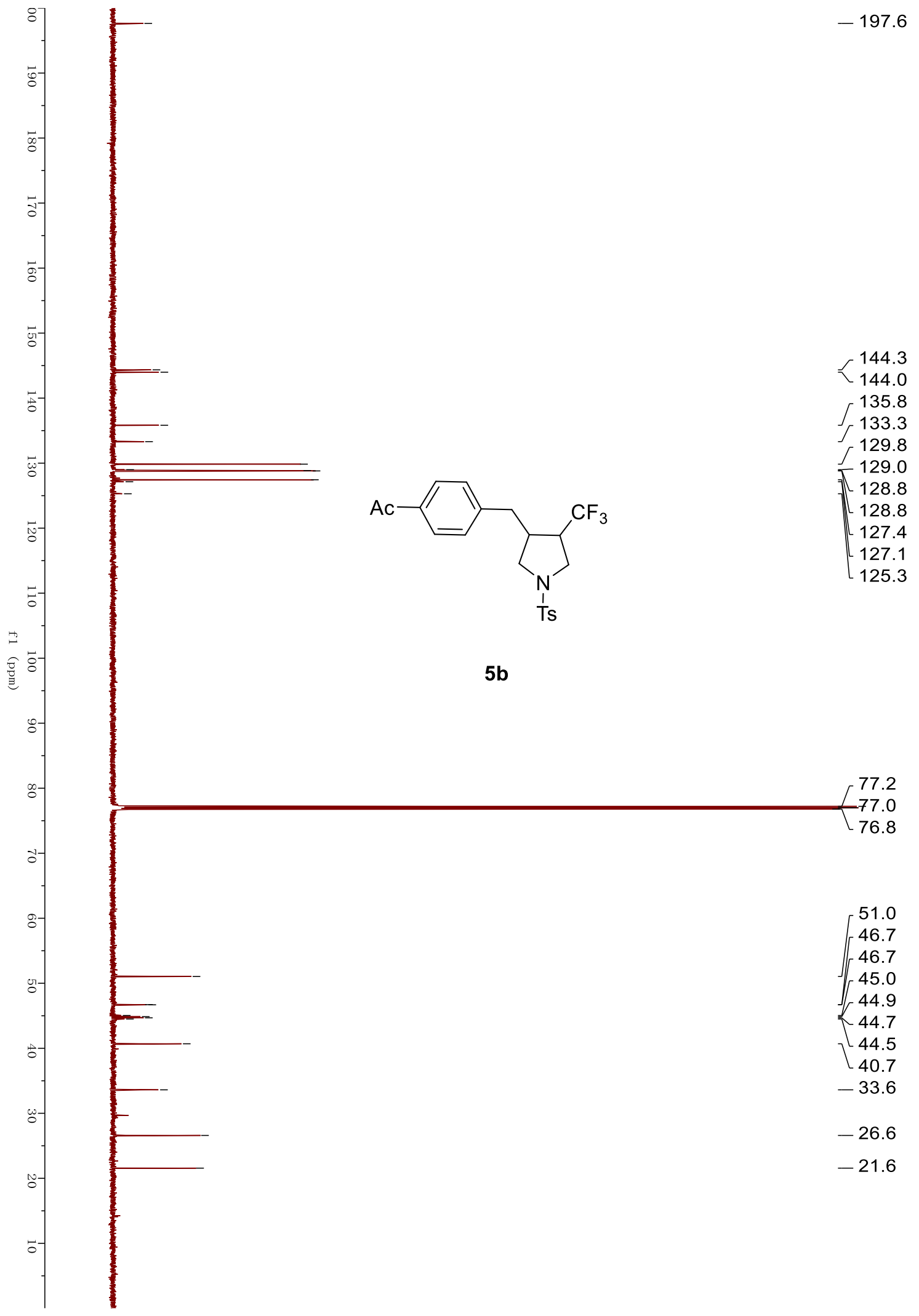


Compound $5 \mathbf{b}{ }^{19} \mathrm{~F}$ NMR (565 MHz, $\mathrm{CDCl}_{3}$ )

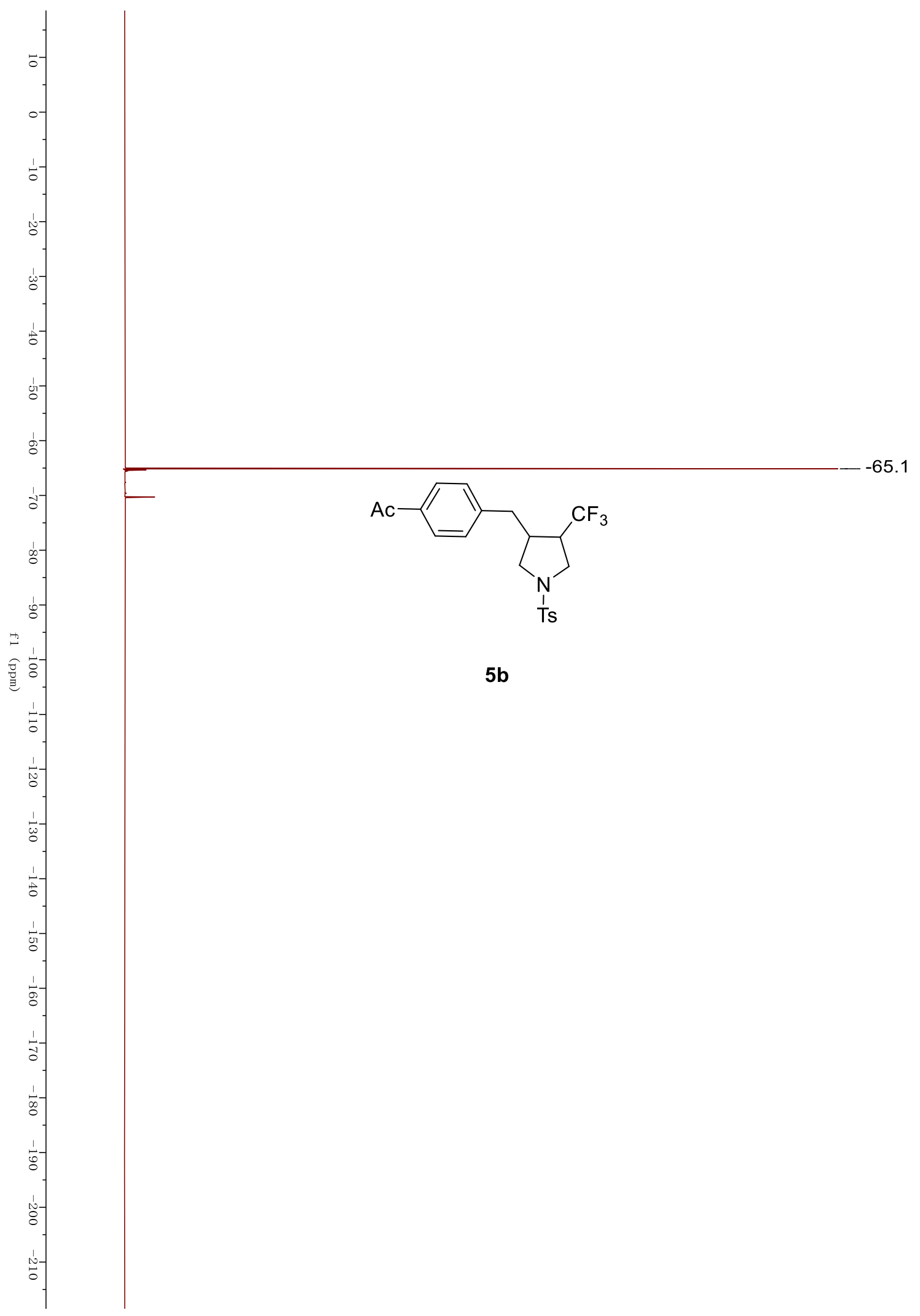

